\title{
The adolescent experience in-depth: Using data to identify and reach the most vulnerable young people-Tanzania 2009-2012
}

Population Council

Tanzania Commission for AIDS (TACAIDS)

Zanzibar AIDS Commission (ZAC)

UNICEF Tanzania

Follow this and additional works at: https://knowledgecommons.popcouncil.org/departments_sbsr-pgy

Part of the Demography, Population, and Ecology Commons, Family, Life Course, and Society Commons, Inequality and Stratification Commons, and the International Public Health Commons How does access to this work benefit you? Let us know!

\section{Recommended Citation}

"The adolescent experience in-depth: Using data to identify and reach the most vulnerable young people-Tanzania 2009-2012." New York: Population Council, 2015. 

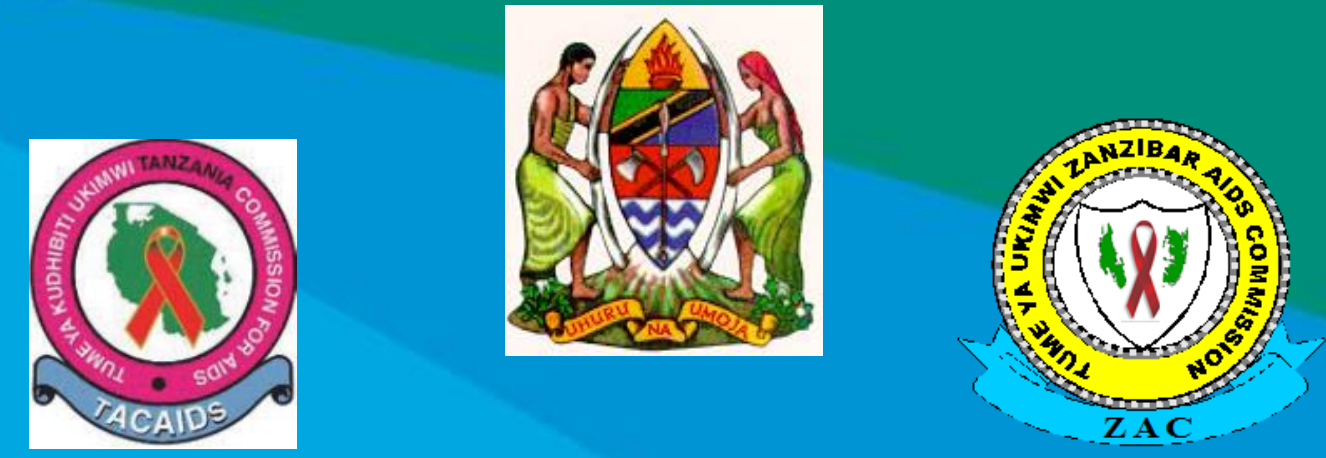

\section{THE ADOLESCENT EXPERIENCE IN-DEPTH: USING DATA TO IDENTIFY AND REACH THE MOST VULNERABLE YOUNG PEOPLE}

\section{TANZANIA 2009-2012}



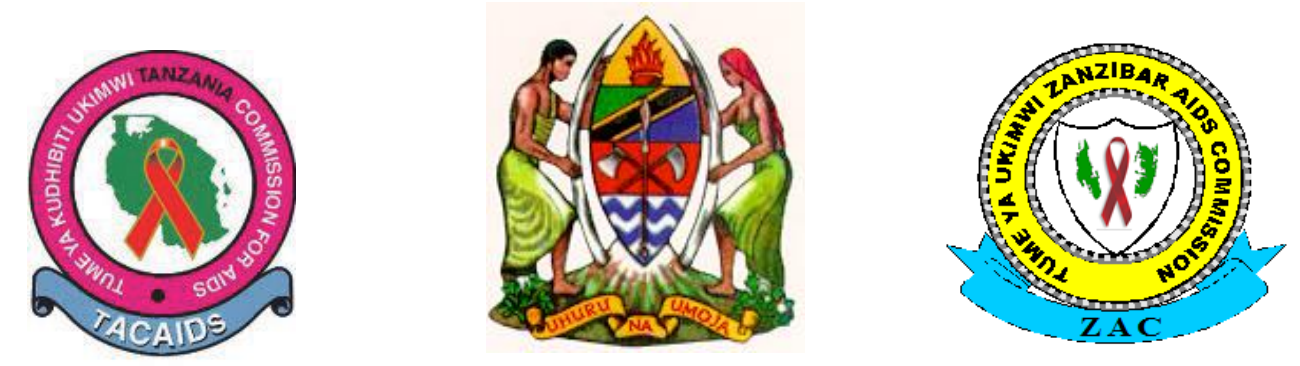

\title{
The Adolescent Experience In-Depth: Using Data to Identify and Reach the Most Vulnerable Young People
}

\section{Tanzania 2009-2012}

\author{
Population Council \\ New York, New York USA
}

Tanzania Commission for AIDS (TACAIDS)

Dar es Salaam, Tanzania

Zanzibar AIDS Commission (ZAC)

Zanzibar, Tanzania

United Nations Children's Fund (UNICEF)

Dar es Salaam, Tanzania 
The Population Council confronts critical health and development issues-from stopping the spread of HIV to improving reproductive health and ensuring that young people lead full and productive lives. Through biomedical, social science, and public health research in 50 countries, we work with our partners to deliver solutions that lead to more effective policies, programmes, and technologies that improve lives around the world. Established in 1952 and headquartered in New York, the Council is a nongovernmental, nonprofit organization governed by an international board of trustees.

Population Council

1 Dag Hammarskjold Plaza

New York, NY 10017

USA

Tel: +1 2123390500

Fax: +12127556052

email: pubinfo@popcounil.org

popcouncil.org

\section{Suggested citation:}

Population Council, Tanzania Commission for AIDS (TACAIDS), Zanzibar AIDS Commission (ZAC), and UNICEF Tanzania. 2015. The Adolescent Experience In-Depth: Using Data to Identify and Reach the Most Vulnerable Young People, Tanzania 2009-2012. Dar es Salaam: Population Council, TACAIDS, ZAC and UNICEF Tanzania. 


\section{Table of Contents}

FOREWORD

ACKNOWLEDGEMENTS

LIST OF ACRONYMS

TECHNICAL NOTES

MAP OF TANZANIA

$\begin{array}{ll}\text { 1.1. Population Distribution } & 7\end{array}$

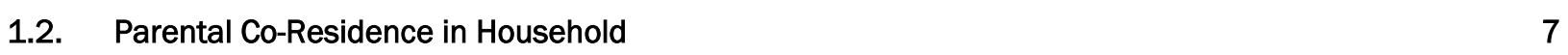

1.3. Parental Survival (Orphan Status) $\quad 9$

1.4. Education 11

1.4.1. Current School Attendance 11

1.4.2. Current School Attendance by Year of Age and Gender 14

1.4.3. In School and in the Recommended Grade for Age (GFA) 16

1.4.4. Current School Attendance by Household Wealth Quintile 18

$\begin{array}{ll}\text { 1.5. Illiteracy } & 18\end{array}$

1.6. Marital Status among Females $\quad 19$

1.6.1. Marital Status by Household Wealth Quintile $\quad 21$

2. KEY EXPERIENCES IN ADOLESCENCE THAT CAN CONTRIBUTE TO DISADVANTAGE 22

2.1. Adolescents Not in School and Not Living with Parents 22

2.2. Illiteracy and Marriage before Age 15/18 23

$\begin{array}{lll}\text { 2.3. School Attendance, by Marital and Childbearing Status } & 23\end{array}$

$\begin{array}{ll}\text { 3. CONTEXT OF SEXUAL ACTIVITY } & 24\end{array}$

3.1. Age at First Marriage or Union among Females $\quad 24$

3.2. Age at First Sex $\quad 26$

3.2.1. Age at First Sex by Household Wealth Quintile $\quad 27$

$\begin{array}{ll}\text { 3.3. Pregnancy and Childbearing among Females } & 27\end{array}$

3.3.1. Pregnancy Status by Household Wealth Quintile 28

3.3.2. Childbearing Before Ages 15 and 18 among Females 28

$\begin{array}{ll}\text { 3.4. Age Difference between Current Partners } & 29\end{array}$ 


\section{EXPOSURE TO VIOLENCE}

4.1. Forced First Sex

4.1.1. Age of First Forced Sex

4.1.2. Perpetrators of First Forced Sex

4.2. Ever Experience Sexual Violence

4.3. Experience of Physical Violence

4.4. Combinations of Violence Experienced

4.5. Perpetrators of Sexual Violence

4.6. Perpetrators of Physical Violence

4.7. Violence during Pregnancy

4.8. Orphan Status and Exposure to Violence

5. HIV/AIDS: KNOWLEDGE AND PREVALENCE

5.1. Knowledge of HIV Prevention Methods 44

5.2. Comprehensive HIV Knowledge 46

5.3. Knowledge of Prevention of Mother-to-Child HIV Transmission (PMTCT) 48

5.4. Attitudes Towards People Living with HIV/AIDS 50

5.5. HIV Testing and Counselling 53

5.6. HIV Prevalence $\quad 55$

6. SEXUAL RISK BEHAVIOURS

6.1. Multiple Sexual Partners and Condom Use 59

6.2. Paid Sex in Last 12 Months and Condom use (Males) 60

6.3. Attitudes Towards Negotiating Condom Use with Husband 61

6.4. Condom Use During Premarital Sex 62

7. REPRODUCTIVE AND MATERNAL HEALTH 64

7.1. Current Contraceptive Use by Marital Status 64

7.2. Antenatal Care During Most Recent Pregnancy 64

7.3. Birth Attendance During Delivery 65

8. EXPOSURE TO MASS MEDIA $\quad 66$ 
9. GEOGRAPHIC HOTSPOTS

Female Hotspots (Extreme)

Female Hotspots (Moderate)

Male Hotspots (Moderate)

10. POLICY, PROGRAMMATIC AND RESEARCH RECOMMENDATIONS

11. REFERENCES

12. ANNEXES 


\section{FOREWORD}

Adolescents (10-19 years) have been recognized as one of the groups most vulnerable to HIV transmission, and comprise $23 \%$ of the Tanzanian population. The Joint United Nations Programme on HIV and AIDS (UNAIDS) and UNICEF agreed on June 62014 to co-lead a multi-partner effort to put this crisis on the radar of policymakers and articulate a bold, clear, and achievable plan to elevate collective actions to close the prevention and treatment gap among adolescents. The All In! initiative towards ending the adolescent AIDS epidemic was announced on 20 July 2014 by UNAIDS Executive Director (Michel Sidibe) at the International AIDS Society Conference in Melbourne, Australia.

In order to achieve the above, programmes and policies meant to improve the well-being and life opportunities of adolescents are urgently needed to take action on HIV and AIDS in young people in order to mitigate the impact of the HIV epidemic. At the same time, there is limited information to facilitate informed decisions on advocacy, monitoring, resource mobilization and allocation. The available data on adolescents are not disaggregated and analysed to support evidence-based programming, particularly in regards to younger adolescent girls.

The objectives of the secondary data analysis/triangulation presented here were to analyse approximately 40 key indicators related to knowledge, attitudes and behaviours and outcomes (including living arrangements, school attendance, illiteracy, marriage, pregnancy, violence and HIV) of females and males ages 10-14, 15-19 and 20-24 years, to determine their specific vulnerabilities at national and regional levels, where possible.

The report Adolescent Experience in Depth: Using Data to Identify and Reach the Most Vulnerable Young People, Tanzania 2009-2012 presents the findings from the in-depth analysis of data from the Tanzania Demographic and Health Survey (TDHS) 2010, the Tanzania HIV and Malaria Indicator Survey (THMIS) 2011-12, and the Violence Against Children in Tanzania Survey (VACS) 2009, to provide evidence for the specific vulnerabilities of male and female young people. The tables and text contained in this report cover many of the most important indicators and should be used by policy makers and programme implementers to evaluate their activities and plan future directions. We hope that stakeholders take advantage of this valuable information to inform policy formulation, planning, monitoring, and evaluation of HIV and AIDS, health and nutrition, education, child protection, and social protection programmes.

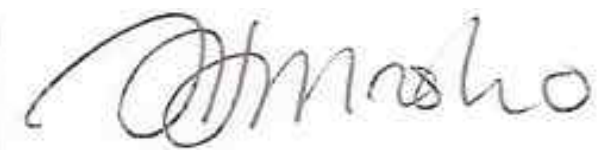

Dr. Fatma H. Mrisho

EXECUTIVE CHAIRPERSON

Tanzania Commission for AIDS

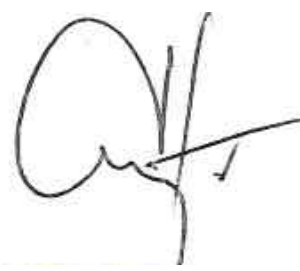

Dr. Omar Shauri

EXECUTIVE DIRECTOR

Zanzibar AIDS Commission 


\section{ACKNOWLEDGEMENTS}

The report Adolescent Experience in Depth: Using Data to Identify and Reach the Most Vulnerable Young People, Tanzania 2009-2012 is only possible because of the extensive research carried out during the 2010 Tanzania Demographic and Health Survey, the 2011-2012 Tanzania HIV/AIDS and Malaria Indicator Survey, and the 2009 Violence Against Children in Tanzania Survey. In addition, this report could not have been generated without the invaluable technical support of the Population Council and technical and financial assistance from the United Nations Children's Fund (UNICEF).

This report represents a collaborative effort of many stakeholders from other organizations and individuals whose participation is acknowledged with gratitude, particularly: the Ministry of Health and Social Welfare (MoHSW); the Ministry of Community Development, Gender and Children (MCDGC); the Zanzibar AIDS Commission (ZAC); the National Bureau of Statistics (NBS); the Office of Chief Government Statistician (OCGS-Zanzibar); the United Nations Fund for Population (UNFPA); the United States Centers for Diseases Control and Prevention (CDC); and the United States Agency for International Development (USAID) in Tanzania.

The Tanzania Commission for AIDS (TACAIDS) and the Zanzibar AIDS Commission (ZAC) would like to acknowledge and extend gratitude to the Adolescent Study Reference Group, which provided technical oversight of this the report. The team comprised Dr. Alison Jenkins, Ms. Victoria Chuwa, Ms. Edith Mbatia and Mr. Tumaini Charles (UNICEF Tanzania); Mr. Deogratius Malamsha and Ms. Elinzuu Nicodemo (NBS); Ms. Mayasa M. Mwinyi (OCGS-Zanzibar); Ms. Nuru Mbarouk and Mr. Said Othman (ZAC); Dr. Aroldia Mulokozi, Dr. Samwel Sumba and Dr. Subilaga K. Kaganda (TACAIDS); Dr. Majaliwa Marwa and Ms. Amina Kheri (UNFPA); Mr. Mathias Haule (MCDGC); and Mr. Clement Kihinga and Dr. Elizabeth Mapella (MoHSW).

From the Population Council, Ms. Katharine McCarthy contributed to the writing of the narrative, data analysis, and production of the data tables associated with the report, while Dr. Kelly Hallman provided intellectual leadership and the policy summary. We also acknowledge Ms. Judith Bruce for her creative input and review of the report, and Ms. Michelle Chau for her assistance with the technical analysis.

Also thanked for invaluable contributions are: Mr. Mlemba Abassy Kamwe (NBS); Ms. Yolande Baker, Ms. Birgithe Lund-Henriksen and Mr. Ayoub Kafyulilo (UNICEF Tanzania), Dr. Judith Diers (UNICEF HQ); Ms. Kathryn Kaplan (CDC); Ms. Maggie Bangser and Dr. Mary Plummer (independent consultants).

Finally, useful feedback received during a January 2015 national validation meeting of the preliminary report helped to refine and improve this final report, particularly its recommendations section. We are very grateful to the 73 individuals who participated in that meeting, including those representing the Mainland and Zanzibar governments (MESWYWC, MIYCS, MOEVT, MOHSW/NACP, OCGS, PMO-RALG, WHUUM); development partners (DFID, UNFPA, UNICEF); international NGOs (Africare, DSW, EngenderHealth, EQUIP, FHI 360, ICAP, JHPIEGO, JHU/CCP, PACT, PSI); and Tanzanian CSOs and other partners (CHAI, Femina-HIP, NACOPHA, Restless Development, TAYOA, THPS, T-MARC, UDSM, ZALA, ZAPHAY, ZAYEDESA, ZHAI, ZIHTLP). 


\section{LIST OF ACRONYMS}

AIDS

ANC

CDC

CSE

DHS

HIV

LMIC

NBS

OCGS

PMTCT

STI

TACAIDS

TDHS

THMIS

TZ

UNAIDS

UNICEF

USAID

VACS

ZAC
Acquired Immune Deficiency Syndrome

Antenatal Care

Centers for Disease Control and Prevention

Comprehensive Sexuality Education

Demographic and Health Survey

Human Immunodeficiency Virus

Low and Middle Income Countries

National Bureau of Statistics

Zanzibar Office of the Chief Government's Statistician

Prevention of Mother-to-Child HIV Transmission

Sexually Transmitted Infection

$$
\text { Tanzania Commission for AIDS }
$$

Tanzania Demographic and Health Survey

Tanzania HIV/AIDS and Malaria Indicator Survey

Tanzania

Joint United Nations Programme on HIV and AIDS

United Nations Children's Fund

United States Agency for International Development

Violence Against Children in Tanzania Survey

Zanzibar AIDS Commission 


\section{TECHNICAL NOTES}

All data presented in this report were calculated using the following sources: (1) the 2010 Tanzania Demographic and Health Survey (TDHS), conducted by the National Bureau of Statistics (NBS) of the United Republic of Tanzania; (2) the 2011-2012 Tanzania HIV/AIDS and Malaria Indicator Survey (THMIS), conducted by the National Bureau of Statistics in collaboration with the Office of the Chief Government Statistician (OCGS-Zanzibar); and (3) the 2009 Violence Against Children in Tanzania Survey (VACS), conducted by the United Nations Children's Fund (UNICEF), the U.S. Centers for Disease Control and Prevention (CDC), and the Muhimbili University of Health and Allied Sciences.

\section{Tanzania Demographic and Health Survey (TDHS)}

The 2010 TDHS surveyed a nationally representative sample of 9,623 households. Household survey data include select indicators on household residents of all ages. In addition to household surveys, individual surveys were conducted with 10,139 women ages 15-49 and 2,527 men ages 15-49. Data presented on adolescents and young people are from both household surveys (age group 10-14) and individual surveys (ages 15+). The data are weighted to be representative at the national, urban/rural and regional levels. More information on the design and results of the 2010 TDHS is provided in the final report (National Bureau of Statistics (NBS) [Tanzania] and ICF Macro. 2011. Tanzania Demographic and Health Survey 2010. Dar es Salaam, Tanzania: NBS and ICF Macro. Information on the Demographic Health Surveys, including final reports and original data, is available at the Demographic and Health Survey (DHS) website at: http://www.measuredhs.com/).

\section{1-2012 Tanzania HIV/AIDS and Malaria Indicator Survey (THMIS)}

The 2011-2012 THMIS surveyed a nationally representative sample of 10,040 households. Household survey data include select indicators on household residents of all ages. In addition to household surveys, individual surveys were conducted with 10,967 women ages 15-49 and 8,352 men ages 15-49. Data presented on adolescents and young people are from both household surveys (age group 10-14) and individual surveys (ages 15+). The data are weighted to be representative at the national, urban/rural and regional levels. More information on the design and results of the 2011-12 THMIS is provided in the final report (Tanzania Commission for AIDS (TACAIDS), Zanzibar AIDS Commission (ZAC), National Bureau of Statistics (NBS) Office of the Chief Government Statistician (OCGS), and ICF International. 2013. Tanzania HIV/AIDS and Malaria Indicator Survey 2011-12. Dar es Salaam, Tanzania: TACAIDS, ZAC, NBS, OCGS, and ICF Macro). Information on Indicator Surveys is also available at the DHS website:

http://www.measuredhs.com/).

\section{Violence Against Children in Tanzania Survey (VACS)}

The 2009 Tanzania VACS was coordinated by UNICEF Tanzania with assistance from the CDC and the Muhimbili University of Health and Allied Sciences. A nationally representative survey of 3,739 females and males ages 13-24 years was implemented using a three-stage cluster household survey design. The data are weighted to conform to the 2002 Census population distribution by region, sex and age group. Data are available for the national level, as well as for Mainland and Zanzibar regions. More information on the design and results of the 2009 Tanzania VACS is provided in the final report (UNICEF Tanzania, Division of Violence Prevention, National Center for Injury Prevention and Control, Centers for Disease Control and Prevention, and Muhimbili University of Health and Allied Sciences, 2011. Violence against Children in Tanzania: Findings from a National Survey, 2009. Summary Report on the Prevalence of Sexual, Physical and Emotional Violence, Context of Sexual Violence, and Health and Behavioural Consequences of Violence Experienced in Childhood. Dar es Salaam, Tanzania: UNICEF, CDC, Muhimbili University of Health and Allied Sciences). The report is available at the UNICEF website: http://www.unicef.org/media/). 


\section{Notes to the Reader}

Given different regional boundries and representativeness, data triangulated across these three sources are not directly comparable. Specifically, several regional boundries were changed by Government between the 2010 TDHS and the 2011-2012 THMIS. Of the former 21 Mainland regions, the boundaries of five (Kagera, Mwanza, Shinyanga, Rukwa, and Iringa) were altered. The boundaries of the remaining 16 are unchanged. Attempts to compare indicators in affected regions should be performed with caution. Figure 2 presents the new regional boundaries (depicted in light grey) and zonal boundaries (defined in bold).

Tables included in this report are disaggregated into groups of interest to the extent that the data represented continue to be accurate. Figures that appear in lightly shaded cells highlighted indicate that the statistic is based on 25-50 unweighted cases, so data should be considered with caution. An asterisk indicates that the statistic is based on fewer than 25 individuals and the data have been suppressed due to instability. A composite Mainland and Zanzibar indicator was constructed in presented TDHS and THMIS data. The Zanzibar indicator is composed of the five following regions: Kaskazini Unguja (Unguja North), Kusini Unguja (Unguja South), Mjini Magharibi (Zanzibar Urban/West), Kaskazini Pemba (Pemba North) and Kusini Pemba (Pemba South). The Mainland indicator is composed of all other regions according to each dataset.

Results presented in all data tables are weighted percents. The weighted percents take into account the sampling design used in each survey and for accurate national and regional estimates.

Specifically, respondents in each survey are assigned a different statistical weight based on how many people his or her response reflects, and allowing for adjustments in sample design and community response rates. Our secondary analysis utilized sample weights calculated by each data source. More information related to the process of how sampling weights were calculated is available in the final report for each data source.

Calculating statistical differences between gender, age group and geographic areas was beyond the scope of the present study. Therefore, when such differences are presented here, they are descriptive only and should not be interpreted as statistically significant.

In this report, we provide information on the methods used to conduct each survey, how indicators were constructed for each data source, and how to interpret information on each indicator. Indicator data are organized by chapter, with a section for each data source examined. For the following results, data first are presented for the 2010 TDHS, followed by the 2011-12 THMIS or the 2009 VACS, when examined. Caution should be used when making direct comparisons among data sources, as the year of data collection, sample population, geographic boundaries, as well as question wording, varied. We provide overall conclusions based on general trends in the data across the examined surveys. Definition of "child", "adolescent", "youth", and "young people" vary across agencies and surveys, but common age labels used in the report are shown in Figure 1.

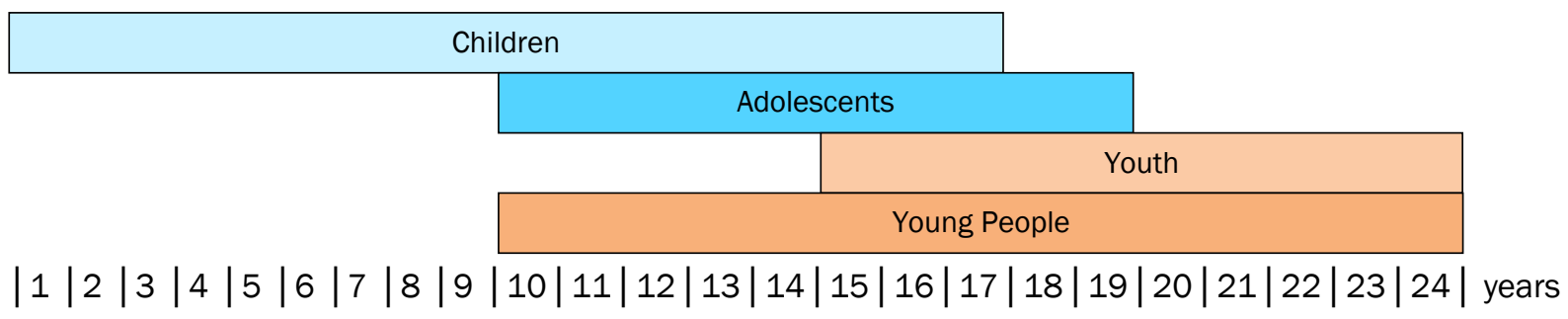

Figure 1. Categorization of children, adolescents, youth, and young people, by age group. 


\section{MAP OF TANZANIA}

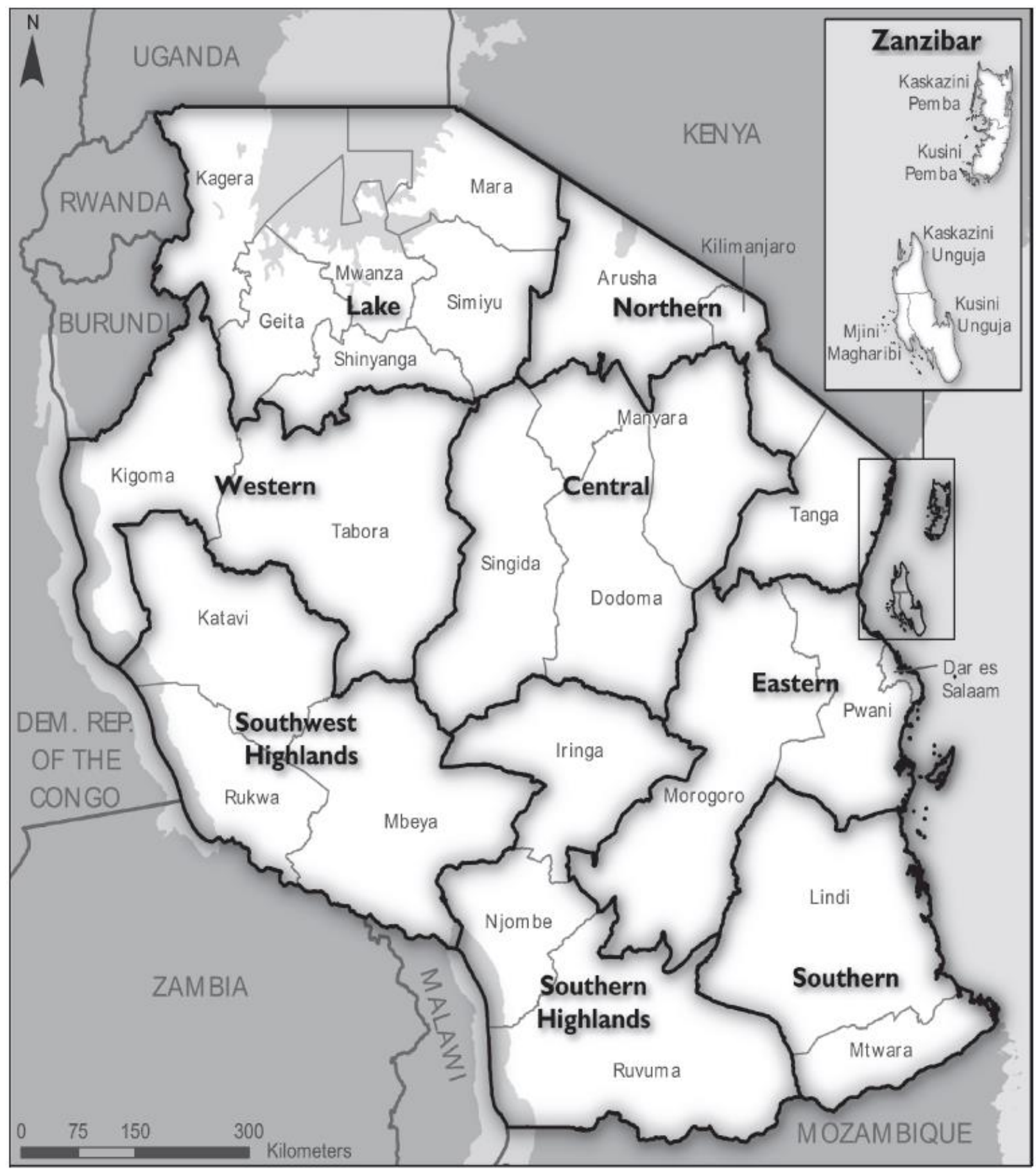

Figure 2. Map of Tanzania, by zone and region, 2011-2012.

Key: Zone boundaries = bold lines; Regional boundaries = light grey lines .

Source: TACAIDS et al. 2013. HIV/AIDS and Malaria Indicator Survey 2011-12. Dar es Salaam: Tanzania Commission for AIDS (TACAIDS), Zanzibar AIDS Commission, NBS, Office of the Chief Government Statistician, and ICF International. 


\section{EXECUTIVE SUMMARY}

This report presents a secondary data analysis and triangulation of the Tanzania Demographic and Health Survey (DHS) 2010, the Tanzania HIV and Malaria Indicator Survey (THMIS) 2011-12, and the Violence Against Children in Tanzania Survey (VACS) 2009. Its objectives are to analyse approximately 40 key indicators related to knowledge, attitudes, behaviours and outcomes (e.g., living arrangements, school attendance, illiteracy, marriage, pregnancy, violence and HIV) of females and males ages 10-14, 15-19 and 20-24 years to determine their specific vulnerabilities at national, urban/rural and regional levels, where possible.

This work was conceptualized to serve three main purposes. The first is to provide a comprehensive analytical report on the situation of adolescents and youth in Tanzania, to be used as a resource for age, gender, and region-specific data by policy makers and programme implementers at national and decentralized levels for policy formulation, planning, monitoring and evaluation across sectors. The second is to identify geographic concentrations of vulnerability -regional "hotspots" for young women and men - for specific consideration and programmatic actions. Lastly, the report serves as an advocacy tool for policy change, which draws on the strengths of three national surveys.

The findings presented here show that $80 \%$ of Tanzanian adolescents ages 10-14 live in rural areas, compared to $\sim 70 \%$ of young people ages $20-24$. Although mortality and other factors may contribute to this difference, youth migration to cities is likely to play an important role. Fully one-quarter of girls and one-fifth of boys ages 10-14 have neither parent in the household, with girls in urban areas particularly affected. About half of girls ages 15-17 in urban areas live with neither parent. These findings may reflect a variety of circumstances and living arrangements, including those related to accessing education, seeking employment (such as domestic labour), and child marriage, each of which generally affects girls and boys differently. Overall, $~ 15 \%$ of adolescents ages 10-17 have only one or neither parent alive, with the highest rates of orphanhood in Dar es Salaam, Iringa and Njombe (for girls) and Iringa and Mara (for boys). Adolescents who do not live with either parent may be in need of additional support and protection.

Although school attendance in the early years of adolescence is similar for both genders, girls, particularly in rural areas, start to drop out or leave school at age 12, and the gender gap in attendance widens with increasing age. On the other hand, boys, particularly in rural areas, are less likely to be at the appropriate grade for their age. Wealth inequities in school attendance are evident even in early adolescence (ages 10-12). Of note, in urban areas, girls are more than twice as likely as boys ages $10-14$ to not be in school and not living with either parent ( $8 \%$ versus $3 \%$ ).

In Tanzania, married girls disproportionately were illiterate, with $58 \%$ of females ages $15-24$ who had been married by 15 years not being able to read a sentence, compared to $12 \%$ of their unmarried peers. Child marriage also places girls at risk of early pregnancy and childbirth, with physical and emotional health risks for the mother, and poorer outcomes for her children. Between $5-6 \%$ of girls are married by age 15 , and $31-37 \%$ by age 18 , with rates differing dramatically by region. Areas with a consistently high proportion of girls married by age 15 are Dodoma, Lindi, Rukwa and Tabora. For marriage before the age 18, regions with a consistently high proportion of married females are Dodoma, Lindi, Mara, Morogoro, Shinyanga, and Tabora. Child marriage is strongly correlated with poverty, with girls ages 15-17 from the poorest households more than twice as likely as those from the wealthiest households to have ever been married. Also of concern are the risks faced by girls who have become widowed, divorced or abandoned, due to both the nature of the dissolution of marriage (i.e., domestic hardship or potential death of husband) and due to social exclusion or economic vulnerability that may exist after marriage. Nationally, $9 \%$ of females ages $20-$ 24 are separated, divorced or widowed. Lindi and Dar es Salaam have the highest rate of previously married girls (greater than 15\%). 
About half of females ages 20-24 transitioned to sexual activity before the age of 18 . In general young people who reside in rural and Mainland areas reported becoming sexualy active at an earlier age than young people in urban areas or in Zanzibar. Regions with consistently higher reports of early sexual activity among females include Mtwara (for first sex before age 15) and Mara, Morogoro, Rukwa and Shinyanga (for first sex before age 18). Males generally reported initiating sexual activity later in life - they are 2.5 times less likely to have had sex before age 15.

Early pregnancy is correlated with household wealth quintile, as girls from the wealthiest households are less likely to report early pregnancy compared to girls in the bottom two wealth quintiles. Overall, $5 \%$ of females age 15 have ever been pregnant, while nearly all of females aged 24 (91\%) have ever been pregnant. The likelihood of early pregnancy is higher among females who reside in Mainland than those in Zanzibar. Young rural females are also more likely to have ever been pregnant compared to those in urban areas. Early pregnancy is most common in Arusha, Lindi and Morogoro (before age 15), and in Dodoma, Lindi and Tabora (before the age of 18).

Overall, about one quarter of married/cohabiting females ages 15-24 are with partners aged 10 or more years older, with highest rates of this difference in Dar es Salaam, Mara and Simiyu. A large age gap between girls and their partners or husbands can put girls at a disadvantage in avoiding violence and negotiating healthy sexual behaviour, as well as at increased risk of HIV infection. In Zanzibar, rates of early marriage, sexual initiation and early pregnancy (before ages 15 and 18) are much lower than on the Mainland, while age differences between women and their husband/cohabiting partners are higher.

More than half (55\%) of females ages 15-24 agree with at least one justification for wife beating, with the highest rates of agreement being in Kagera, Kigoma and Mara. Acceptance of at least one justification for wife beating is slightly lower among same aged males (50\%), and much lower in Zanzibar among both women and men ages 15-24 (30\% and 29\%, respectively). Acceptance of the use of violence towards females early in life can lay a foundation for future unequal sexual relationships, and previous research has documented a correlation between acceptance of unequal gender norms and the experience of violence. Moreover, adverse consequences of violence against females include unintended pregnancy and HIV infection.

Emotional, physical and sexual violence against women and children is widespread in Tanzania. Rates of physical and sexual violence vary considerably by region, as do gender norms surrounding domestic violence. Three in ten girls and two in ten boys ages 15-24 reported experiencing force at sexual initiation, and one in ten girls report physical violence during pregnancy. A sizeable proportion of females and males experience sexual violence during their childhood. Research has documented that sexual risk-taking behaviours can be associated with early exposure to sexual violence, including multiple partnerships and infrequent or no condom use. It is imperative that future prevention work with children and adults in communities also address the social dynamics and risk factors that underpin the problem of sexual violence, including, but not limited to, poverty, male entitlement, age, income inequality, and alcohol and drug consumption.

The majority of adolescents possess basic knowledge of HIV prevention methods, that is, using condoms and limiting the number of concurrent sexual partners can reduce the risk of HIV transmission, with substantial regional variation. Less than half of youth have comprehensive HIV knowledge as defined by the surveys, that is: know that a health-looking person can have HIV; reject two common misconceptions about HIV/AIDS and prevention; and know the above two HIV prevention methods. Both knowledge of HIV prevention methods and comprehensive HIV knowledge were lower among rural youth and Zanzibar youth than their urban and Mainland counterparts, especially for boys. More female than male youth knew about prevention of mother-to-child HIV transmission, with urban youth and Zanzibar youth demonstrating higher levels of knowledge. In terms of attitudes towards people living with HIV, results varied dramatically by region in Mainland Tanzania, with female and male youth in Zanzibar showing higher rates of acceptance overall. 
While awareness of HIV testing locations is high, there is marked regional variation in access to HIV testing. HIV testing increases by age, and is higher in urban than rural areas and higher in the Mainland compared to Zanzibar, particularly among males. Among those who were interviewed and tested, HIV positivity rates vary by urban/rural and Mainland/Zanzibar areas among youth ages 1519 and $20-24$.

A relatively small percent of adolescents reported multiple sexual partnerships, but reports increased markedly with age (7\% for ages $15-19$, versus $~ 22 \%$ for ages $20-24$ ). Rates were higher among youth in rural areas and Mainland, than among those in urban areas and Zanzibar. Reported condom use during last high-risk sex, on the other hand, seemed to be higher among male and female adolescents ages 15-19 compared to youth aged 20-24. While 15\% males ages 15-24 reported paying for sex in the past 12 months (more commonly in rural areas compared to urban, and Mainland compared to Zanzibar), less than half of them reported using a condom during last paid sex. Gender differences in reported condom use during premarital sex varied by age: it was higher for girls than boys ages 15-17 (48\% versus 38\%), but higher for men than women ages $20-24$ $(60 \%$ versus $48 \%)$. Taken together, low rates of condom use among youth, combined with high rates of multiple sexual partners among males, may facilitate the spread of HIV in Tanzania, particularly in rural areas.

Only one in five currently married girls and three in ten never married, sexually active girls are currently using any modern contracteption method, with particularly low rates in urban areas and in Zanzibar. More than half (60\%) of ever-pregnant females ages 15-24 were assisted by a health professional during their most recent delivery, with no notable difference by age, indicating that extra efforts need to be made to reach adolescents with needed sexual reproductive health services, to reduce unintended pregnancies, and to encourage safe deliveries, particularly in rural areas.

Exposure to mass media (as measured by access to newspaper, radio, TV, or ownership of a mobile phone) is lower among young females than males, especially in rural areas, and varies considerably by region.

Given the above results, and the regional variability across most of the indicators examined, we identified regions which are "hotspots", that is, particularly unfavorable in terms of HIV vulnerability and risk for either boys or girls when compared to the national mean. We identified nine key variables: school attendance (ages 10-14); school attendance and parental residence; early childbearing; early marriage; partner age differences (greater than 10 year age difference); sexual violence; HIV prevention knowledge; comprehensive HIV knowledge; and HIV prevalence. The regions proving to be extreme hotspots for girls (defined as having three key variables that are exceptionally unfavorable) include Dar es Salaam, Mara, Morogoro, Simiyu and Tabora. Geographic areas proving to be moderate hotspots for girls (defined as having two key variables that are exceptionally unfavorable) were Arusha, Kaskazini Unguja, Iringa, Lindi, Mbeya, Njombe, Rukwa. Among boys, there were no geographic areas that were extreme hotspots, likely because four of the variables could be measured for girls only. There were, however, several moderate hotspots for boys: Dodoma, Kagera, Kaskazini Pemba and Lindi.

This report has wide-ranging and important implications for many Tanzanian policies and programmes, including those related to child marriage, school re-entry after dropout, pregnancy, and age of consent for HIV testing and counselling. The findings are an urgent call for improved coordination and dissemination of existing policies and stronger implementation of existing plans which protect the sexual and reproductive health and rights of adolescents and youth. The findings also highlight where new policies and plans may be needed to address critical gaps. Detailed policy, programmatic and research recommendations based on these results can be found on pages 75-76 of this report. 


\section{MAPPING THE DIVERSITY OF ADOLESCENTS}

This chapter describes the demographic and household characteristics of young people, including sex and age distribution by region, parental co-residence, parental survival, education, and marital status.

\subsection{Population Distribution}

Programmes and policies which target young people must address the diverse contexts and environments where they reside to be most effective (Mavedzenge et al. 2011). The social and economic circumstances and availability of resources related to health, education or income generation may differ markedly between urban and rural areas (UNICEF 2012).

The household distribution of surveyed young people is shown in Table 1A.

\begin{tabular}{|c|c|c|c|c|}
\hline & \multicolumn{2}{|c|}{2010 TDHS } & \multicolumn{2}{|c|}{ 2011-12 THMIS } \\
\hline & Urban & Rural & Urban & Rural \\
\hline \multicolumn{5}{|l|}{ Females } \\
\hline $10-14$ & 21.6 & 78.4 & 19.9 & 80.1 \\
\hline $15-19$ & 28.9 & 71.1 & 27.3 & 72.7 \\
\hline $15-17$ & 29.1 & 70.9 & 28.4 & 71.6 \\
\hline $18-19$ & 28.5 & 71.5 & 25.8 & 74.2 \\
\hline $20-24$ & 33.0 & 67.0 & 28.7 & 71.3 \\
\hline \multicolumn{5}{|l|}{ Males } \\
\hline $10-14$ & 19.6 & 80.4 & 18.2 & 81.8 \\
\hline $15-19$ & 24.6 & 75.4 & 23.5 & 76.5 \\
\hline $15-17$ & 24.1 & 75.9 & 21.1 & 78.9 \\
\hline $18-19$ & 25.3 & 74.7 & 27.2 & 72.8 \\
\hline $20-24$ & 28.4 & 71.6 & 28.9 & 71.1 \\
\hline
\end{tabular}

As both adolescent boys and girls age, there is a higher likelihood of residing in urban settings, which may be related to educational and employment opportunities (UN Population Division 2014; World Bank 2014). In both surveys, approximately $80 \%$ of males and females ages 10-14 live in rural areas. This percent decreases to approximately $70 \%$ of respondents ages $20-24(67 \%$ and $71 \%$ of females, and $72 \%$ and $71 \%$ of males, in the TDHS and THMIS, respectively). The vast majority of young people surveyed live in Mainland Tanzania, while less than $5 \%$ reside in Zanzibar (see Annex Table 1B).

\subsection{Parental Co-Residence in Household}

Adolescent co-residence with at least one parent is often correlated with greater access to resources such as income, social support, housing and protection (Ngom et al. 2003; Wamoyi et al. 2015). While adolescent co-residence with both parents does not ensure provided benefits, adolescents who reside without one or both parents may be in need of additional support.

Tables 2A1-2 and 2B1-2 present data on parental co-residence among adolescents ages 10-14 and 15-17 by sex. In both the TDHS and the THMIS, about half of adolescents ages 10-14 co-reside with both parents, while one-quarter of girls (25\%) and one-fifth of boys (20\%) have neither parent in the household. With increasing age, co-residence with both parents decreases by 10 to $15 \%$ among both males and females, with urban areas and females most affected. Across both surveys, half of females ages 15-17 in urban areas reside with neither parent. 
2010 TDHS: A higher percent of urban (36\%) relative to rural (22\%) females ages 10-14 lack both parents in the household. This trend is also evident among males and females ages 15-17. Girls living in urban areas are particularly vulnerable to living with neither parent. More respondents ages 15-17 who reside in Mainland Tanzania relative to Zanzibar lack both parents in the household. Among adolescents ages 10-14 this pattern is observed for males only.

\begin{tabular}{|c|c|c|c|c|c|c|c|c|}
\hline \multirow{2}{*}{ Region } & \multicolumn{2}{|c|}{ Both parents in $\mathrm{HH}$} & \multicolumn{2}{|c|}{ Mother only in $\mathrm{HH}$} & \multicolumn{2}{|c|}{ Father only in $\mathrm{HH}$} & \multicolumn{2}{|c|}{ Neither parent in $\mathrm{H}$} \\
\hline & Females & Males & Females & Males & Females & Males & Females & Males \\
\hline Mainland & 48.7 & 52.6 & 18.6 & 18.0 & 7.9 & 9.0 & 24.8 & 20.3 \\
\hline Zanzibar & 52.7 & 65.1 & 13.1 & 14.2 & 4.2 & 4.6 & 30.1 & 16.1 \\
\hline Urban & 36.7 & 49.8 & 20.7 & 20.0 & 7.1 & 9.8 & 35.5 & 20.4 \\
\hline Rural & 52.1 & 53.8 & 17.9 & 17.4 & 8.0 & 8.7 & 22.0 & 20.2 \\
\hline National & 48.8 & 53.0 & 18.5 & 17.9 & 7.8 & 8.9 & 24.9 & 20.2 \\
\hline
\end{tabular}

\begin{tabular}{|c|c|c|c|c|c|c|c|c|}
\hline \multirow{2}{*}{ Region } & \multicolumn{2}{|c|}{ Both parents in $\mathrm{HH}$} & \multicolumn{2}{|c|}{ Mother only in $\mathrm{HH}$} & \multicolumn{2}{|c|}{ Father only in $\mathrm{HH}$} & \multicolumn{2}{|c|}{ Neither parent in $\mathrm{HH}$} \\
\hline & Females & Males & Females & Males & Females & Males & Females & Males \\
\hline Mainland & 38.5 & 44.1 & 16.5 & 18.7 & 6.9 & 8.7 & 38.2 & 28.5 \\
\hline Zanzibar & 49.6 & 59.1 & 17.5 & 14.7 & 4.2 & 7.5 & 28.6 & 18.7 \\
\hline Urban & 28.7 & 40.8 & 15.6 & 14.8 & 5.4 & 9.0 & 50.3 & 35.4 \\
\hline Rural & 43.0 & 45.8 & 16.9 & 19.7 & 7.3 & 8.6 & 32.7 & 25.9 \\
\hline National & 38.9 & 44.6 & 16.5 & 18.5 & 6.8 & 8.7 & 37.8 & 28.2 \\
\hline
\end{tabular}

Regional data on parental co-residence in the household are presented in Annex Table 2A-1 and 2A2. In general, more females than males ages 10-14 live without either parent in the household in every region except for Mara and Shinyanga. The five regions with the highest percent of females ages 10-14 who lack both parents in the household are Dar es Salaam (37\%), Mtwara, (36\%), Pwani (37\%), Kusini Unguja (39\%) and Mjini Magharibi (33\%).

2011-12 THMIS: Nationally, more than one-fifth of adolescents ages 10-14 have neither parent in the household ( $23 \%$ of females, $21 \%$ of males), which increases to $41 \%$ of females and $29 \%$ of males by the ages of 15-17. A higher percent of urban than rural adolescents lack both parents in the household, which is similar to findings observed in the TDHS (although the difference is marginal among males ages 10-14 in the THMIS). Also, similar to TDHS findings, a higher percent of Mainland relative to Zanzibar adolescents lack both parents in the household at ages 15-17.

\begin{tabular}{|c|c|c|c|c|c|c|c|c|}
\hline \multirow{2}{*}{ Region } & \multicolumn{2}{|c|}{ Both parents in $\mathrm{HH}$} & \multicolumn{2}{|c|}{ Mother only in $\mathrm{HH}$} & \multicolumn{2}{|c|}{ Father only in $\mathrm{HH}$} & \multicolumn{2}{|c|}{ Neither parent in $\mathrm{HH}$} \\
\hline & Females & Males & Females & Males & Females & Males & Females & Males \\
\hline Mainland & 50.7 & 51.8 & 20.1 & 18.1 & 6.7 & 8.8 & 22.5 & 21.4 \\
\hline Zanzibar & 52.8 & 60.3 & 19.0 & 13.5 & 3.7 & 10.9 & 24.5 & 15.3 \\
\hline Urban & 42.4 & 46.6 & 21.1 & 21.6 & 5.4 & 9.1 & 31.2 & 22.7 \\
\hline Rural & 52.9 & 53.2 & 19.8 & 17.1 & 6.9 & 8.8 & 20.4 & 20.9 \\
\hline National & 50.8 & 52.0 & 20.1 & 17.9 & 6.6 & 8.9 & 22.6 & 21.2 \\
\hline
\end{tabular}




\begin{tabular}{|c|c|c|c|c|c|c|c|c|}
\hline \multirow{2}{*}{ Region } & \multicolumn{2}{|c|}{ Both parents in $\mathrm{HH}$} & \multicolumn{2}{|c|}{ Mother only in $\mathrm{HH}$} & \multicolumn{2}{|c|}{ Father only in $\mathrm{HH}$} & \multicolumn{2}{|c|}{ Neither parent in $\mathrm{HH}$} \\
\hline & Females & Males & Females & Males & Females & Males & Females & Males \\
\hline Mainland & 35.1 & 43.8 & 17.5 & 17.8 & 6.2 & 9.6 & 41.2 & 28.7 \\
\hline Zanzibar & 49.1 & 53.6 & 15.7 & 14.5 & 9.3 & 9.7 & 25.9 & 22.1 \\
\hline Urban & 24.4 & 33.6 & 18.2 & 20.2 & 4.9 & 7.2 & 52.5 & 39.0 \\
\hline Rural & 40.1 & 47.0 & 17.1 & 17.1 & 6.9 & 10.3 & 35.9 & 25.6 \\
\hline National & 35.6 & 44.2 & 17.4 & 17.7 & 6.4 & 9.6 & 40.6 & 28.5 \\
\hline
\end{tabular}

Regional data on parental co-residence in the household are presented in Annex Tables 2B-1 and 2B-2. For adolescents ages 10-14 the percent of boys who live without both parents is higher (more than a 5\% difference) than same-aged girls in Katavi, Lindi and Shinyanga. Areas where the percent of girls ages 10-14 who live without both parents exceeds that of boys of the same age (more than $5 \%$ difference) include: Dar es Salaam, Iringa, Kigoma, Manyara, Mwanza, Pwani, Tanga, Kaskazini Unguja, Kusini Unguja, Mjini Magharibi and Kusini Pemba (see Annex Tables 2B1-2).

\subsection{Parental Survival (Orphan Status)}

Tables 3A1-2 and 3B1-2 present data on parental survival among adolescents ages 10-14 and 1517 by sex. In both the TDHS and the THMIS, between 12-13\% of adolescents ages 10-14 have only one parent living, while $2 \%$ have lost both parents. Unsurprisingly, the likelihood of losing one or both parents increases with age. By ages 15-17, between 16-18\% of adolescents have lost one parent, and 3-5\% have lost both parents. Urban-rural and Mainland-Zanzibar differences vary somewhat by survey as described below.

2010 TDHS: Among adolescents ages 10-14, a higher percent of females have neither parent alive in urban (4\%) relative to rural (2\%) areas, while there is no equivalent urban to rural difference for males of the same age. For adolescents ages 15-17, however, a higher percent of males who live in urban $(8 \%)$ relative to rural areas $(3 \%)$ have neither parent alive; there is no equivalent urban to rural difference for girls of the same age. A higher percent of adolescents who reside in Mainland relative to Zanzibar areas have neither parent alive, across examined age groups and sexes.

\begin{tabular}{|c|c|c|c|c|c|c|}
\hline Table 3A-1: Parental Survival Among 10-14 Year Olds, Percent (DHS 2010) \\
\hline \multirow{2}{*}{ Region } & Both parents alive & One parent dead & Neither parent alive \\
\cline { 2 - 7 } & Females & Males & Females & Males & Females & Males \\
\hline Mainland & 84.0 & 84.6 & 13.4 & 13.4 & 2.5 & 1.9 \\
\hline Zanzibar & 89.8 & 92.0 & 9.8 & 7.4 & 0.4 & 0.6 \\
\hline Urban & 82.6 & 85.7 & 13.0 & 12.9 & 4.1 & 1.5 \\
\hline Rural & 84.6 & 84.7 & 13.4 & 13.3 & 1.9 & 1.9 \\
\hline National & 84.2 & 84.9 & 13.3 & 13.2 & 2.4 & 1.8 \\
\hline $\begin{array}{l}\text { Note: Read first column of data as "Percent of 10-14 year old females with both parents } \\
\text { living," using 2010 TDHS. }\end{array}$
\end{tabular}




\begin{tabular}{|c|c|c|c|c|c|c|}
\hline Table 3A-2: Parental Survival Among 15-17 Year Olds, Percent (DHS 2010) \\
\hline \multirow{2}{*}{ Region } & Both parents alive & One parent alive & Neither parent alive \\
\cline { 2 - 7 } & Females & Males & Females & Males & Females & Males \\
\hline Mainland & 77.0 & 77.3 & 18.0 & 18.6 & 4.9 & 4.0 \\
\hline Zanzibar & 86.6 & 89.3 & 13.0 & 8.7 & 0.4 & 2.0 \\
\hline Urban & 74.1 & 79.7 & 21.1 & 12.6 & 4.8 & 7.7 \\
\hline Rural & 78.7 & 77.1 & 16.4 & 20.1 & 4.6 & 2.6 \\
\hline National & 77.3 & 77.7 & 17.8 & 18.3 & 4.7 & 3.9 \\
\hline $\begin{array}{l}\text { Note: Read first column of data as "Percent of 15-17 year old females with both parents } \\
\text { living," using 2010 TDHS. }\end{array}$
\end{tabular}

For adolescents ages 10-14, the region with the lowest percent with both parents alive is Iringa (75\% girls, $74 \%$ boys). For adolescents ages 15-17, Iringa is the area with the lowest percent of boys with both parents alive (57\%), while for girls it is Dar es Salaam (only 60\% have both parents alive) (see Annex Tables 3A1-2).

2011-12 THMIS: Similar to the TDHS, a higher percent of adolescents ages 10-14 who reside in Mainland relative to Zanzibar areas have neither parent alive. For adolescents ages 15-17, this pattern is observed for males only. There are negligible urban to rural differences among adolescents for whom neither parent is alive in the THMIS.

\begin{tabular}{|c|c|c|c|c|c|c|}
\hline \multirow{2}{*}{ Region } & \multicolumn{2}{|c|}{ Both parents alive } & \multicolumn{2}{|c|}{ One parent alive } & \multicolumn{2}{|c|}{ Neither parent alive } \\
\hline & Females & Males & Females & Males & Females & Males \\
\hline Mainland & 85.8 & 84.6 & 12.5 & 12.9 & 1.7 & 2.2 \\
\hline Zanzibar & 90.8 & 94.0 & 8.9 & 5.7 & 0.3 & 0.2 \\
\hline Urban & 86.9 & 82.7 & 11.5 & 14.4 & 1.5 & 2.5 \\
\hline Rural & 85.7 & 85.4 & 12.6 & 12.3 & 1.7 & 2.1 \\
\hline National & 85.9 & 84.9 & 12.4 & 12.7 & 1.7 & 2.1 \\
\hline
\end{tabular}

\begin{tabular}{|c|c|c|c|c|c|c|}
\hline \multirow{2}{*}{ Region } & \multicolumn{2}{|c|}{ Both parents alive } & \multicolumn{2}{|c|}{ One parent alive } & \multicolumn{2}{|c|}{ Neither parent alive } \\
\hline & Females & Males & Females & Males & Females & Males \\
\hline Mainland & 79.4 & 79.8 & 17.3 & 16.2 & 3.2 & 3.7 \\
\hline Zanzibar & 88.2 & 85.5 & 8.5 & 14.3 & 3.3 & 0.2 \\
\hline Urban & 76.6 & 75.4 & 19.7 & 20.3 & 3.7 & 4.3 \\
\hline Rural & 81.1 & 81.3 & 15.9 & 15.1 & 3.0 & 3.4 \\
\hline National & 79.8 & 80.1 & 17.0 & 16.2 & 3.2 & 3.6 \\
\hline
\end{tabular}

Regions with the lowest percent of males ages 10-14 who have both parents alive are Iringa and Mara (70\%, respectively). For same-aged females, the area which has the lowest percent of females with both parents alive is Iringa (70\%) (see Annex Tables 3B1-2). Regional data for adolescents ages 15-17 are limited by small sample sizes. 


\subsection{Education}

Education is a key element of healthy adolescent development and transition into adulthood (WHO 2003; West et al. 2004). In addition to knowledge and skills, schools can provide a relatively safe space to develop protective social networks and to create links future income-generating opportunities. Appropriate, targeted policies and programmes that help to keep young people enrolled and attending school throughout adolescence, and connected to the social network that schools provide, can have important impacts on their personal development and can minimize their vulnerabilities to challenges that exist outside of the school environment (Hargreaves et al. 2008; Jukes et al. 2008).

\subsubsection{Current School Attendance}

Tables 4A-1 and 4A-2 present data on current school attendance for males and females ages 10-14 and 15-19, respectively, disaggregated by region. Additional data tables which further subdivide current school attendance by age $(15-17,18-19)$, as well as those calculated using the THMIS, appear as Annex Tables 4A3-5 and 4B1-5.

Data from both the TDHS and THMIS demonstrate a trend of decreasing school attendance with increasing age, a finding that is particularly evident among females. By ages 15-19, a large proportion of females are not attending school (61\% in TDHS, 55\% in THMIS). A smaller, but still sizeable percent of same-aged males are not attending school (50\% in TDHS, $45 \%$ in THMIS). Both surveys support the finding that there is an overall low transition rate from primary to secondary education in Tanzania. For both surveys, more rural than urban adolescents are out of school. Mainland adolescents are also more likely to be out of school than adolescents who reside in Zanzibar.

2010 TDHS: Tables 4A1-2 shows that approximately equivalent proportions of males and females ages 10-14 did not attend school during the current school year (16\% of females and $15 \%$ of males). By ages 15-19, the percent of adolescents who are not in school increases substantially (61\% of females and $50 \%$ of males).

Regions with the highest percent of out-of-school females ages 10-14 include: Kagera, Kigoma, Mbeya, Morogoro, and Tabora. In each of these areas, the percent of girls who are not in school exceeds $20 \%$. Kilimanjaro has the lowest percent of girls not in school $(1.4 \%)$, while Tabora has the highest (30\%).

Regions with the highest percent of out-of-school males ages 10-14 include: Dodoma, Kagera, Lindi, Morogoro and Tabora (i.e., the percent of boys not in school exceeds 20\%). Mjini Magharibi has the lowest percent of boys not in school (2\%), whereas Tabora and Dodoma have the highest percent (22\%, respectively).

Gender disparities in current school attendance are noteworthy in Kigoma, Manyara, and Tabora, where $8 \%, 8 \%$ and $7 \%$ more girls ages $10-14$ are out of school than boys, respectively. 


\begin{tabular}{|c|c|c|c|c|c|c|}
\hline \multirow[b]{2}{*}{ Region } & \multicolumn{3}{|c|}{ Females } & \multicolumn{3}{|c|}{ Males } \\
\hline & $\begin{array}{l}\text { Not in } \\
\text { school }\end{array}$ & $\begin{array}{l}\text { Attending } \\
\text { primary }\end{array}$ & $\begin{array}{l}\text { Attending } \\
\text { secondary }\end{array}$ & $\begin{array}{l}\text { Not in } \\
\text { school }\end{array}$ & $\begin{array}{c}\text { Attending } \\
\text { primary }\end{array}$ & $\begin{array}{l}\text { Attending } \\
\text { secondary }\end{array}$ \\
\hline \multicolumn{7}{|l|}{ Mainland } \\
\hline Arusha & 12.1 & 80.8 & 5.4 & 11.7 & 82.8 & 5.5 \\
\hline Dar es Salaam & 10.9 & 70.3 & 18.8 & 6.8 & 82.2 & 11.1 \\
\hline Dodoma & 16.4 & 80.0 & 3.7 & 21.6 & 77.4 & 1.1 \\
\hline Iringa & 13.5 & 79.1 & 6.2 & 16.1 & 82.7 & 1.2 \\
\hline Kagera & 21.7 & 76.3 & 1.3 & 21.5 & 75.7 & 1.9 \\
\hline Kigoma & 21.9 & 78.1 & 0.0 & 13.8 & 86.2 & 0.0 \\
\hline Kilimanjaro & 1.4 & 86.6 & 12.1 & 5.7 & 81.9 & 12.4 \\
\hline Lindi & 16.0 & 84.0 & 0.0 & 21.5 & 78.5 & 0.0 \\
\hline Manyara & 16.3 & 79.6 & 3.2 & 9.1 & 86.3 & 3.8 \\
\hline Mara & 9.8 & 86.0 & 4.3 & 7.7 & 86.3 & 6.1 \\
\hline Mbeya & 21.5 & 77.6 & 0.9 & 15.5 & 82.2 & 2.3 \\
\hline Morogoro & 24.1 & 73.8 & 2.1 & 21.0 & 77.3 & 1.7 \\
\hline Mtwara & 14.3 & 81.9 & 3.9 & 15.6 & 83.4 & 1.0 \\
\hline Mwanza & 19.2 & 75.8 & 4.4 & 17.6 & 77.5 & 4.9 \\
\hline Pwani & 9.3 & 87.8 & 2.9 & 8.8 & 88.5 & 2.7 \\
\hline Rukwa & 19.9 & 79.2 & 0.9 & 14.7 & 85.3 & 0.0 \\
\hline Ruvuma & 6.2 & 91.2 & 2.1 & 6.7 & 86.9 & 6.4 \\
\hline Shinyanga & 15.2 & 83.1 & 1.7 & 17.8 & 80.7 & 1.5 \\
\hline Singida & 11.0 & 87.7 & 1.4 & 12.7 & 82.5 & 3.5 \\
\hline Tabora & 29.7 & 68.4 & 1.9 & 21.6 & 75.8 & 2.1 \\
\hline Tanga & 14.0 & 80.9 & 3.8 & 11.9 & 80.2 & 6.0 \\
\hline \multicolumn{7}{|l|}{ Zanzibar } \\
\hline Kaskazini Unguja & 4.8 & 92.9 & 1.5 & 15.4 & 81.5 & 3.1 \\
\hline Kusini Unguja & 2.5 & 90.3 & 7.2 & 6.2 & 90.2 & 3.6 \\
\hline Mjini Magharibi & 3.4 & 86.9 & 9.7 & 1.8 & 88 & 10.2 \\
\hline Kaskazini Pemba & 13.9 & 80.3 & 5.8 & 13.2 & 83.4 & 3.4 \\
\hline Kusini Pemba & 4.7 & 91.8 & 3.5 & 10.9 & 87.1 & 2.0 \\
\hline Mainland & 16.2 & 79.7 & 3.8 & 14.9 & 81.2 & 3.7 \\
\hline Zanzibar & 5.6 & 88.1 & 6.3 & 8.3 & 86.1 & 5.5 \\
\hline Urban & 12.7 & 76.3 & 11.0 & 9.9 & 82.7 & 7.3 \\
\hline Rural & 16.7 & 80.9 & 1.9 & 15.9 & 81.0 & 2.8 \\
\hline National & 15.9 & 79.9 & 3.9 & 14.7 & 81.3 & 3.7 \\
\hline
\end{tabular}

Results from the TDHS also illustrate that a large percent of adolescents ages 15-19 are out of school, particularly females. Regions with the highest percents of out-of-school females in this age group include: Dodoma, Lindi, Kigoma, Manyara, Mbeya, Mtwara, Mwanza, Rukwa, Shinyanga, Pwani and Tabora. The percent of out-of-school females in each of these areas exceeds $60 \%$. Kilimanjaro has the lowest percent of out-of-school girls ages 15-19 (29\%), while Lindi has the highest percent (81\%).

Among 15-19 year olds, school attendance gender disparities are striking in Kigoma, Mara, Rukwa and Shinyanga, where 30\%, 23\%, 33\% and 25\% more girls are out of school compared to boys, respectively. 


\begin{tabular}{|c|c|c|c|c|c|c|}
\hline \multirow[b]{2}{*}{ Region } & \multicolumn{3}{|c|}{ Females } & \multicolumn{3}{|c|}{ Males } \\
\hline & $\begin{array}{l}\text { Not in } \\
\text { school }\end{array}$ & $\begin{array}{c}\text { Attending } \\
\text { primary }\end{array}$ & $\begin{array}{l}\text { Attending } \\
\text { secondary }\end{array}$ & $\begin{array}{l}\text { Not in } \\
\text { school }\end{array}$ & $\begin{array}{c}\text { Attending } \\
\text { primary }\end{array}$ & $\begin{array}{l}\text { Attending } \\
\text { secondary }\end{array}$ \\
\hline \multicolumn{7}{|l|}{ Mainland } \\
\hline Arusha & 45.3 & 11.5 & 43.3 & 51.4 & 28.1 & 20.5 \\
\hline Dar es Salaam & 59.2 & 5.5 & 35.3 & 45.0 & 7.5 & 47.5 \\
\hline Dodoma & 66.6 & 11.9 & 21.6 & 57.1 & 32.0 & 10.9 \\
\hline Iringa & 53.9 & 7.1 & 38.9 & 46.5 & 9.8 & 43.7 \\
\hline Kagera & 51.8 & 24.8 & 23.4 & 51.1 & 20.2 & 28.7 \\
\hline Kigoma & 64.8 & 16.9 & 18.2 & 34.7 & 21.5 & 43.8 \\
\hline Kilimanjaro & 28.7 & 9.7 & 61.6 & 36.2 & 16.9 & 47.0 \\
\hline Lindi & 80.7 & 14.1 & 5.2 & 68.5 & 9.4 & 22.1 \\
\hline Manyara & 62.5 & 15.0 & 22.5 & 47.3 & 14.6 & 38.1 \\
\hline Mara & 75.8 & 5.1 & 19.0 & 52.4 & 18.9 & 28.7 \\
\hline Mbeya & 65.1 & 9.1 & 25.8 & 56.9 & 22.2 & 20.9 \\
\hline Morogoro & 54.7 & 7.3 & 38.0 & 55.1 & 17.7 & 27.2 \\
\hline Mtwara & 60.2 & 10.0 & 29.9 & 54.5 & 13.5 & 32.1 \\
\hline Mwanza & 64.1 & 15.0 & 20.9 & 49.9 & 18.4 & 31.7 \\
\hline Pwani & 62.4 & 18.8 & 18.8 & 45.8 & 26.0 & 28.3 \\
\hline Rukwa & 75.9 & 14.4 & 9.8 & 42.5 & 36.9 & 20.6 \\
\hline Ruvuma & 59.5 & 9.4 & 31.1 & 58.6 & 11.4 & 30.1 \\
\hline Shinyanga & 73.4 & 13.2 & 13.4 & 48.3 & 33.4 & 18.2 \\
\hline Singida & 62.0 & 11.4 & 26.7 & 65.3 & 14.2 & 20.5 \\
\hline Tabora & 71.2 & 10.7 & 18.1 & 60.6 & 21.7 & 17.7 \\
\hline Tanga & 55.5 & 11.8 & 32.7 & 42.1 & 30.4 & 27.5 \\
\hline \multicolumn{7}{|l|}{ Zanzibar } \\
\hline Kaskazini Unguja & 38.8 & 16.3 & 44.9 & 45.9 & 23.9 & 30.2 \\
\hline Kusini Unguja & 46.7 & 5.7 & 47.6 & 50.5 & 11.1 & 38.4 \\
\hline Mjini Magharibi & 30.6 & 5.7 & 63.7 & 30.1 & 13.5 & 56.4 \\
\hline Kaskazini Pemba & 35.5 & 14.4 & 50.2 & 33.2 & 26.9 & 39.9 \\
\hline Kusini Pemba & 32.6 & 17.7 & 49.7 & 31.6 & 23.8 & 44.6 \\
\hline Mainland & 61.4 & 12.0 & 26.5 & 50.5 & 20.4 & 29.0 \\
\hline Zanzibar & 34.9 & 11.9 & 53.2 & 35.6 & 19.7 & 44.6 \\
\hline Urban & 49.5 & 6.8 & 43.8 & 38.2 & 11.8 & 50.1 \\
\hline Rural & 64.9 & 14.1 & 20.9 & 53.9 & 23.2 & 23.0 \\
\hline National & 60.5 & 12.0 & 27.5 & 50.1 & 20.4 & 29.6 \\
\hline
\end{tabular}

2011-12 THMIS: Data from the THMIS (presented in Annex Tables 4B1-5) show that at ages 10-14, $11 \%$ of females and $14 \%$ of males did not attend school during the current school year. By ages 1519 , the proportion of out-of-school youth rises to $55 \%$ of females and $44 \%$ of males.

Similar to the TDHS, the percent of out-of-school youth varies by region. Regions with the highest percent of out-of-school females ages 10-14 according to THMIS data are Katavi (30\% of females ages 10-14 are not in school), Shinyanga (20\%), Rukwa and Tabora (19\%, respectively). Kusini Unguja has the lowest percent of out-of-school females (0\%). For males of the same age, more than $20 \%$ are not in school in six regions: Katavi, Lindi, Shinyanga, Mbeya, Tabora, and Rukwa. Katavi is the region with the highest percent of out-of-school males aged 10-14 (28\%) and Mijini Magharibi has the lowest percent (1\%). In contrast to the 2010 TDHS, gender disparaties in the 2011-12 THMIS indicate that more 10-14 year old boys than girls are out of school in Arusha, Dodoma, Lindi, Mbeya, Kaskazini Unguja (13\%, 10\%, 16\%, 9\%, and 9\% difference respectively). 
In nine regions, the percent of out-of-school females ages 15-19 exceeds 60\%: Dodoma, Geita, Katavi, Kigoma, Mara, Morogoro, Shinyanga, Simiyu and Singida, with the highest area being Dodoma (71\%). The percent of males ages 15-19 years who are out of school is relatively lower than that of females, but is still high. In four regions the percent of out-of-school males ages 15-19 exceeds 55\%: Dodoma, Shinyanga, Singida, and Tanga with Singida having the highest percent (59\%).

\subsubsection{Current School Attendance by Year of Age and Gender}

There has been an increase in adolescent school participation rates over the last several decades in low- and middle-income countries (Johnson 2008). Despite this trend, there are still major differences in school participation by gender, urban/rural residence, and marital status, among other factors.

Knowing adolescents' current school attendance by specific year of age (rather than by broad age groups) can improve understanding of when adolescents are vulnerable to dropping out of school. Table 5 presents data on current school attendance by specific years of age in the 10-17 year old range among females and males by urban-rural status, according to the TDHS. Overall, a difference in school attendance by sex increases with age. This pattern is observed in both urban and rural areas. Of particular note is a $15 \%$ increase in the urban girls who are not in school between the ages of 12 and 13. An additional 10\% of urban girls are not in school by age 15 (33\% overall). Among rural girls, there is a large drop off in school attendance between ages 13 and 14 (19\% decrease), and an additional 12\% decline by age 15 .

School attendance by specific age in the THMIS shows a greater proportion of girls attending school compared to boys, especially at ages 13-14 (see Annex Table 4B-5). Similar to the TDHS, school attendance is lower in rural compared to urban areas, and non-attendance rises with increasing age, with almost two in ten 14 year old girls and boys not attending school. 


\begin{tabular}{|c|c|c|c|c|c|}
\hline & & \multicolumn{2}{|c|}{ Not currently attending school } & \multicolumn{2}{|c|}{ Currently attending school } \\
\hline & & Females & Males & Females & Males \\
\hline Age & Region & & & & \\
\hline \multirow{3}{*}{ Age 10} & Urban & 2.0 & 2.8 & 98.0 & 97.2 \\
\hline & Rural & 10.0 & 13.7 & 90.0 & 86.3 \\
\hline & National & 8.4 & 11.8 & 91.6 & 88.2 \\
\hline \multirow{3}{*}{ Age 11} & Urban & 3.3 & 1.8 & 96.7 & 98.2 \\
\hline & Rural & 12.0 & 12.8 & 88.0 & 87.2 \\
\hline & National & 10.2 & 10.4 & 89.8 & 89.6 \\
\hline \multirow{3}{*}{ Age 12} & Urban & 8.3 & 6.2 & 91.7 & 93.8 \\
\hline & Rural & 10.6 & 12.8 & 89.4 & 87.2 \\
\hline & National & 10.2 & 11.7 & 89.8 & 88.3 \\
\hline \multirow[t]{3}{*}{ Age 13} & Urban & 22.7 & 13.0 & 77.3 & 87.0 \\
\hline & Rural & 16.6 & 17.1 & 83.4 & 82.9 \\
\hline & National & 18.2 & 16.2 & 81.8 & 83.8 \\
\hline \multirow[t]{3}{*}{ Age 14} & Urban & 24.3 & 25.6 & 75.7 & 74.4 \\
\hline & Rural & 36.3 & 23.6 & 63.7 & 76.4 \\
\hline & National & 33.8 & 24.0 & 66.2 & 76.0 \\
\hline \multirow[t]{3}{*}{ Age 15} & Urban & 33.1 & 23.9 & 66.9 & 76.1 \\
\hline & Rural & 48.1 & 37.1 & 51.9 & 62.9 \\
\hline & National & 43.7 & 34.0 & 56.3 & 66.0 \\
\hline \multirow[t]{3}{*}{ Age 16} & Urban & 41.0 & 32.9 & 59.0 & 67.1 \\
\hline & Rural & 58.7 & 49.1 & 41.3 & 50.9 \\
\hline & National & 53.9 & 44.8 & 46.1 & 55.2 \\
\hline \multirow[t]{3}{*}{ Age 17} & Urban & 41.8 & 31.3 & 58.2 & 68.7 \\
\hline & Rural & 67.5 & 58.1 & 32.5 & 41.9 \\
\hline & National & 59.5 & 52.2 & 40.5 & 47.8 \\
\hline \multirow[t]{3}{*}{ Age 18} & Urban & 67.6 & 47.6 & 32.4 & 52.4 \\
\hline & Rural & 73.7 & 63.3 & 26.3 & 36.7 \\
\hline & National & 71.9 & 59.5 & 28.1 & 40.5 \\
\hline \multirow[t]{3}{*}{ Age 19} & Urban & 67.6 & 56.9 & 32.4 & 43.1 \\
\hline & Rural & 73.7 & 64.6 & 26.3 & 35.4 \\
\hline & National & 71.9 & 62.6 & 28.1 & 37.4 \\
\hline
\end{tabular}




\subsubsection{In School and in the Recommended Grade for Age (GFA)}

Of interest is whether adolescents are in the recommended grade for their age. Adolescents who lag two years or more behind their peers in their current grade may be at increased risk of school dropout. Table 6 presents data on current school attendance and grade for age (GFA) status among males and females surveyed in the 2010 TDHS.

TDHS 2010: A higher percent of females are at the appropriate grade for their age relative to males. This trend is observed across the ages of 10 to 17 and becomes increasingly apparent with age. Specifically, at age $10,85 \%$ of females and $77 \%$ of males are in school and at their grade for age, by age 17 this declines to $64 \%$ of females and only $37 \%$ of males who are in school and at their grade for age. In general, adolescents who reside in rural compared to urban, and in Mainland compared to Zanzibar areas, are less likely to currently attend school at their recommended grade for age. Notably, a substantially higher percent of females who reside in urban areas and Zanzibar attend school in general and specifically at the recommended grade for their age, relative to females in rural areas and the Mainland, respectively. For example, at age 16, $88 \%$ of females with urban residence and $66 \%$ of females with residence in Zanzibar were in school and in the recommended grade for their age, compared to only $44 \%$ of females in rural areas and $59 \%$ of females on the Mainland. 


\begin{tabular}{|c|c|c|c|c|c|}
\hline \multicolumn{6}{|c|}{ Table 6: In Schoola and at Grade for Age (GFA) ${ }^{b}$, by Age Group and Sex, Percent (DHS 2010) } \\
\hline \multirow[b]{2}{*}{ Age } & \multirow[b]{2}{*}{ Region } & \multicolumn{2}{|c|}{ Females } & \multicolumn{2}{|c|}{ Males } \\
\hline & & In school & $\begin{array}{c}\text { In school and } \\
\text { at GFA }\end{array}$ & In school & $\begin{array}{c}\text { In school and } \\
\text { at GFA }\end{array}$ \\
\hline \multirow[t]{5}{*}{ Age 10} & Urban & 98.0 & 94.6 & 97.2 & 91.5 \\
\hline & Rural & 90.0 & 82.7 & 86.3 & 73.6 \\
\hline & Mainland & 91.6 & 85.4 & 88.2 & 76.9 \\
\hline & Zanzibar & 94.3 & 85.9 & 88.5 & 80.1 \\
\hline & National & 91.6 & 85.4 & 88.2 & 77.0 \\
\hline \multirow[t]{5}{*}{ Age 11} & Urban & 96.7 & 93.4 & 98.2 & 87.8 \\
\hline & Rural & 88.0 & 80.6 & 87.2 & 69.4 \\
\hline & Mainland & 89.6 & 83.5 & 89.5 & 73.8 \\
\hline & Zanzibar & 95.7 & 82.1 & 95.9 & 78.1 \\
\hline & National & 89.8 & 83.5 & 89.6 & 73.9 \\
\hline \multirow[t]{5}{*}{ Age 12} & Urban & 91.7 & 87.5 & 93.8 & 83.0 \\
\hline & Rural & 89.4 & 72.8 & 87.2 & 60.8 \\
\hline & Mainland & 89.7 & 75.6 & 88.2 & 64.4 \\
\hline & Zanzibar & 95.1 & 79.5 & 91.7 & 73.6 \\
\hline & National & 89.8 & 75.8 & 88.3 & 64.6 \\
\hline \multirow[t]{5}{*}{ Age 13} & Urban & 77.3 & 83.8 & 87.0 & 70.4 \\
\hline & Rural & 83.4 & 69.0 & 82.9 & 61.8 \\
\hline & Mainland & 81.5 & 72.2 & 83.5 & 64 \\
\hline & Zanzibar & 94.2 & 81.8 & 93.7 & 57.4 \\
\hline & National & 81.8 & 72.6 & 83.8 & 63.8 \\
\hline \multirow[t]{5}{*}{ Age 14} & Urban & 75.7 & 80.2 & 74.4 & 76.2 \\
\hline & Rural & 63.7 & 62.0 & 76.4 & 45.7 \\
\hline & Mainland & 65.6 & 66.0 & 75.5 & 51.2 \\
\hline & Zanzibar & 92.5 & 80.2 & 90.2 & 66.4 \\
\hline & National & 66.2 & 66.5 & 76.0 & 51.8 \\
\hline \multirow[t]{5}{*}{ Age 15} & Urban & 66.9 & 72.2 & 76.1 & 70.6 \\
\hline & Rural & 51.9 & 35.1 & 62.9 & 28.1 \\
\hline & Mainland & 55.2 & 46.2 & 65.6 & 39.2 \\
\hline & Zanzibar & 85.8 & 78.7 & 77.9 & 48.6 \\
\hline & National & 56.3 & 48.0 & 66.0 & 39.6 \\
\hline \multirow[t]{5}{*}{ Age 16} & Urban & 59.0 & 88.0 & 67.1 & 64.2 \\
\hline & Rural & 41.3 & 44.4 & 50.9 & 31.7 \\
\hline & Mainland & 45.1 & 59.1 & 54.6 & 41.7 \\
\hline & Zanzibar & 77.5 & 65.6 & 71.8 & 50.4 \\
\hline & National & 46.1 & 59.5 & 55.2 & 42.1 \\
\hline \multirow[t]{5}{*}{ Age 17} & Urban & 58.2 & 84.5 & 68.7 & 62.7 \\
\hline & Rural & 32.5 & 47.4 & 41.9 & 24.5 \\
\hline & Mainland & 39.5 & 64.0 & 47.1 & 36.4 \\
\hline & Zanzibar & 64.0 & 62.3 & 71.2 & 43.1 \\
\hline & National & 40.5 & 63.9 & 47.8 & 36.7 \\
\hline \multicolumn{6}{|c|}{$\begin{array}{l}\text { Note: Read first data column as "Percent of } 10 \text { year old females who attended school in year of survey," } \\
\text { using } 2010 \text { TDHS. } \\
\text { a Attendance at any time during current school year. b Less than } 2 \text { year lag in respondent's grade for age. }\end{array}$} \\
\hline
\end{tabular}




\subsubsection{Current School Attendance by Household Wealth Quintile}

2010 TDHS: Tables 7A and 7B present data on current school attendance among females and males ages 10-17, respectively, by household wealth quintile. Data reveal substantial differences in school attendance by household wealth quintile. Across age groups, poor adolescents - especially girls - are most likely to be out of school, while school attendance is highest among boys in the wealthiest households.

\begin{tabular}{l}
\hline \multicolumn{4}{|c|}{ Table 7A: Current School Attendance a by Wealth Quintile among Females Ages 10-17, } \\
Percent (DHS 2010)
\end{tabular}

\begin{tabular}{|c|c|c|c|}
\hline \multicolumn{4}{|c|}{$\begin{array}{l}\text { Table 7B: Current School Attendance }{ }^{\text {a }} \text { by Wealth Quintile among Males Ages 10-17, } \\
\text { Percent (DHS 2010) }\end{array}$} \\
\hline \multirow{2}{*}{$\begin{array}{c}\text { Household } \\
\text { Wealth Quintile }\end{array}$} & Ages 10-12 & Ages 13-14 & Ages 15-17 \\
\hline & \% In school & $\%$ In school & \% In school \\
\hline Lowest & 80.0 & 77.6 & 48.8 \\
\hline Second & 81.7 & 74.2 & 44.2 \\
\hline Middle & 92.1 & 76.7 & 55.6 \\
\hline Fourth & 95.1 & 84.3 & 59.0 \\
\hline Highest & 98.1 & 89.4 & 74.3 \\
\hline \multicolumn{4}{|c|}{$\begin{array}{l}\text { Note: Read first data column as "Percent of } 10-12 \text { year old males not in school by household wealth } \\
\text { quintile," using } 2010 \text { TDHS. } \\
\text { a Attendance at any time during current school year. }\end{array}$} \\
\hline
\end{tabular}

\subsection{Illiteracy}

The ability to read and write (literacy) is an important personal asset which allows women and men increased opportunities in life (Lloyd and Hewett 2009). There are strong correlations between limited schooling, illiteracy and child marriage (see Sections 1.6 and 3.1).

2010 TDHS: Table 8A presents data on illiteracy among male and female youth. Nationally, $16 \%$ of females ages 15-19 and 15\% of same-aged males are illiterate. Rates of illiteracy are higher among youth ages 20-24 for both sexes, and gender disparities become very apparent at this age (29\% of females, $19 \%$ of males). Rural and Mainland areas have a notably higher percent of illiterate males and females ages 15-24 relative to urban areas and Zanzibar. Specifically, in rural areas 1 in 5 females ages 15-19 (20\%) and nearly 2 in 5 females ages 20-24 (35\%) are illiterate. In urban areas 1 in 20 females ages 15-19 (5\%) and about 1 in 7 females ages 20-24 (15\%) are illiterate.

There is large variability in illiteracy among adolescents by region, although the ability to robustly assess illiteracy by region among males is limited by small sample sizes. Regions where the percent of illiterate females ages 15-19 exceeds 25\% include: Shinyanga (31\%), Tabora (30\%) and Rukwa (27\%). Regions with the lowest illiteracy among females ages 15-19 are Kilimanjaro (1\%), Kusini Unguja and Mijni Magharibi (3\%, respectively). See Annex Tables 8A-B for data on additional age sub-groups. 


\begin{tabular}{|c|c|c|c|c|}
\hline \multirow[b]{2}{*}{ Region } & \multicolumn{2}{|c|}{ Females } & \multicolumn{2}{|c|}{ Males } \\
\hline & Ages 15-19 & Ages 20-24 & Ages 15-19 & Ages 20-24 \\
\hline \multicolumn{5}{|l|}{ Mainland } \\
\hline Arusha & 5.7 & 31.5 & * & * \\
\hline Dar es Salaam & 5.8 & 14.6 & 3.2 & * \\
\hline Dodoma & 21.4 & 40.7 & * & * \\
\hline Iringa & 13.1 & 10.7 & 10.4 & * \\
\hline Kagera & 12.6 & 27.1 & 29.7 & * \\
\hline Kigoma & 9.0 & 28.0 & * & * \\
\hline Kilimanjaro & 1.4 & 18.4 & 7.5 & * \\
\hline Lindi & 20.6 & 34.5 & * & * \\
\hline Manyara & 10.2 & 34.0 & * & * \\
\hline Mara & 15.3 & 35.8 & 10.5 & * \\
\hline Mbeya & 23.7 & 31.3 & 14.6 & * \\
\hline Morogoro & 14.1 & 37.0 & 13.7 & * \\
\hline Mtwara & 13.1 & 23.2 & * & * \\
\hline Mwanza & 19.1 & 29.9 & 27.1 & 21.2 \\
\hline Pwani & 11.8 & 34.3 & * & * \\
\hline Rukwa & 27.1 & 36.5 & * & * \\
\hline Ruvuma & 11.3 & 19.3 & * & * \\
\hline Shinyanga & 30.7 & 34.7 & 14.6 & * \\
\hline Singida & 18.8 & 18.6 & 13.6 & * \\
\hline Tabora & 29.9 & 52.2 & 22.8 & * \\
\hline Tanga & 12.9 & 31.5 & * & * \\
\hline \multicolumn{5}{|l|}{ Zanzibar } \\
\hline Kaskazini Unguja & 11.8 & 15.1 & 20.2 & * \\
\hline Kusini Unguja & 3.0 & 6.3 & 0.0 & 0.0 \\
\hline Mjini Magharibi & 3.1 & 1.9 & 3.5 & * \\
\hline Kaskazini Pemba & 15.2 & 23.9 & 5.4 & * \\
\hline Kusini Pemba & 10.7 & 19.5 & 0.0 & 0.0 \\
\hline Mainland & 16.3 & 29.1 & 15.7 & 19.9 \\
\hline Zanzibar & 8.4 & 10.9 & 6.8 & 3.6 \\
\hline Urban & 4.9 & 14.9 & 5.6 & 6.7 \\
\hline Rural & 20.7 & 35.2 & 18.7 & 23.9 \\
\hline National & 16.0 & 28.5 & 15.4 & 18.8 \\
\hline \multicolumn{5}{|c|}{$\begin{array}{l}\text { Notes: Read first data column as "Percent of } 15-19 \text { year old females who were unable to read a } \\
\text { sentence provided during the survey," using } 2010 \text { TDHS; Highlighted cells are based on } 25-50 \\
\text { unweighted cases; Highlighted cells marked with an asterisk are based on }<25 \text { unweighted cases } \\
\text { and are suppressed. }\end{array}$} \\
\hline
\end{tabular}

\subsection{Marital Status among Females}

Marriage before the age of 18 is considered child marriage; it often places girls at risk of a number of adverse health and social consequences (UN CRC 2003; Clark et al. 2006). These include the risk of pregnancy and childbirth before full maturation, inadequate schooling, restricted social networks and mobility, and limited control over resources.

2010 TDHS: Table 9 presents the percent distribution of females ages 15-24 by marital status. In presented findings, the term 'married' includes legal or formal marriage, or an informal union in which a man and woman live together. The percent of females who are currently married increases greatly from ages 15-19 to ages 20-24 (18\% to 63\%). Across age groups, a higher percent of currently married females reside in rural relative to urban areas. A higher proportion of currently married girls also reside in Mainland as opposed to Zanzibar. The three areas with the highest 
percent of ever married females ages 15-19 (i.e., currently married or separated, divorced or widowed) are Mara (43\%), Shinyanga (37\%), and Tabora (38\%).

Also of concern are the risks faced by girls who have been widowed, divorced or abandoned. These risks relate to both the nature of the dissolution of marriage (i.e., domestic hardship or potential death of husband from HIV), and to social exclusion or economic vulnerability that may exist after marriage. Nationally, 9\% females ages 20-24 are separated, divorced or widowed. Lindi and Dar es Salaam are the two areas with the highest rate of previously married girls (greater than 15\%).

\begin{tabular}{|c|c|c|c|c|c|c|}
\hline \multirow{2}{*}{\multicolumn{3}{|c|}{\begin{tabular}{l|l} 
Table 9: & Marital Status among Fen \\
& $\begin{array}{c}\text { Currently married or } \\
\text { in union }\end{array}$ \\
\cline { 2 - 3 } & Aoes
\end{tabular}}} & \multirow{2}{*}{\multicolumn{2}{|c|}{$\begin{array}{l}\text { les Ages 15-24, Per } \\
\text { Separated, } \\
\text { divorced, widowed }\end{array}$}} & \multirow{2}{*}{\multicolumn{2}{|c|}{ Never married }} \\
\hline & & & & & & \\
\hline Region & $\begin{array}{r}\text { Ages } \\
15-19\end{array}$ & $\begin{array}{l}\text { Ages } \\
20-24\end{array}$ & $\begin{array}{r}\text { Ages } \\
15-19\end{array}$ & $\begin{array}{l}\text { Ages } \\
20-24\end{array}$ & $\begin{array}{r}\text { Ages } \\
15-19\end{array}$ & $\begin{array}{c}\text { Ages } \\
20-24\end{array}$ \\
\hline \multicolumn{7}{|l|}{ Mainland } \\
\hline Arusha & 9.3 & 64.0 & 0.0 & 2.6 & 90.7 & 33.4 \\
\hline Dar es Salaam & 9.1 & 39.2 & 0.4 & 17.4 & 90.5 & 43.5 \\
\hline Dodoma & 20.2 & 70.0 & 0.0 & 7.2 & 79.8 & 22.8 \\
\hline Iringa & 3.1 & 50.2 & 0.0 & 4.4 & 96.9 & 45.4 \\
\hline Kagera & 19.5 & 68.0 & 0.9 & 4.9 & 79.5 & 27.1 \\
\hline Kigoma & 10.0 & 60.5 & 1.1 & 5.3 & 88.9 & 34.2 \\
\hline Kilimanjaro & 8.3 & 52.6 & 0.0 & 15.6 & 91.7 & 31.8 \\
\hline Lindi & 28.6 & 59.1 & 3.4 & 23.2 & 68.0 & 17.8 \\
\hline Manyara & 15.6 & 66.2 & 0.0 & 1.9 & 84.4 & 31.9 \\
\hline Mara & 42.8 & 80.4 & 0.0 & 3.1 & 57.2 & 16.5 \\
\hline Mbeya & 25.1 & 66.2 & 1.0 & 9.7 & 73.9 & 24.1 \\
\hline Morogoro & 17.2 & 61.6 & 0.0 & 11.5 & 82.8 & 26.9 \\
\hline Mtwara & 9.0 & 70.6 & 3.1 & 17.0 & 88.0 & 12.4 \\
\hline Mwanza & 19.0 & 62.6 & 2.7 & 9.3 & 78.3 & 28.1 \\
\hline Pwani & 18.2 & 68.3 & 0.0 & 6.2 & 81.8 & 25.5 \\
\hline Rukwa & 23.7 & 81.6 & 5.6 & 2.8 & 70.7 & 15.6 \\
\hline Ruvuma & 12.5 & 65.6 & 0.0 & 11.1 & 87.5 & 23.3 \\
\hline Shinyanga & 35.2 & 81.6 & 1.8 & 9.9 & 63.0 & 8.5 \\
\hline Singida & 12.6 & 72.3 & 1.8 & 1.6 & 85.6 & 26.1 \\
\hline Tabora & 34.9 & 75.8 & 3.1 & 12.4 & 62.0 & 11.9 \\
\hline Tanga & 4.4 & 55.2 & 3.6 & 3.1 & 92.0 & 41.7 \\
\hline \multicolumn{7}{|l|}{ Zanzibar } \\
\hline Kaskazini Unguja & 8.1 & 54.5 & 0.7 & 6.2 & 91.2 & 39.3 \\
\hline Kusini Unguja & 12.2 & 47.1 & 2.4 & 8.6 & 85.4 & 44.3 \\
\hline Mjini Magharibi & 4.2 & 31.7 & 0.0 & 4.7 & 95.8 & 63.7 \\
\hline Kaskazini Pemba & 5.0 & 43.1 & 0.0 & 7.1 & 95.0 & 49.8 \\
\hline Kusini Pemba & 7.9 & 43.3 & 0.0 & 5.6 & 92.1 & 51.1 \\
\hline Mainland & 18.8 & 64.2 & 1.3 & 9.1 & 79.8 & 26.8 \\
\hline Zanzibar & 6.4 & 40.4 & 0.3 & 5.8 & 93.3 & 53.8 \\
\hline Urban & 9.3 & 46.7 & 0.3 & 9.8 & 90.4 & 43.5 \\
\hline Rural & 22.2 & 71.6 & 1.7 & 8.5 & 76.1 & 19.9 \\
\hline National & 18.4 & 63.4 & 1.3 & 8.9 & 80.3 & 27.7 \\
\hline
\end{tabular}




\subsubsection{Marital Status by Household Wealth Quintile}

2010 TDHS: Table 10 presents data on ever married females ages 15-17, including those currently married, separated, divorced or widowed, by household wealth quintile. $18 \%$ of females in the poorest households have ever been married, compared to $7 \%$ of females in the wealthiest households.

\begin{tabular}{|c|c|c|}
\hline \multicolumn{3}{|c|}{$\begin{array}{l}\text { Table 10: Marital Status Among Females Ages 15-17, } \\
\text { Percent (2010 DHS) }\end{array}$} \\
\hline $\begin{array}{c}\text { Household Wealth } \\
\text { Quintile }\end{array}$ & Never married & Ever married \\
\hline Lowest & 82.1 & 17.9 \\
\hline Second & 84.4 & 15.6 \\
\hline Middle & 85.7 & 14.3 \\
\hline Fourth & 90.9 & 9.1 \\
\hline Highest & 92.6 & 7.4 \\
\hline
\end{tabular}

Section 3.1 examines age at first marriage among females, by specific year of age and by region. 


\section{KEY EXPERIENCES IN ADOLESCENCE THAT CAN CONTRIBUTE TO DISADVANTAGE}

Adolescence (ages 10-19) includes a transition out of childhood and into puberty, a period of biological development that often coincides with a change in social roles as well as emotional and cognitive changes (Caldwell et al. 1998; Plummer and Wight 2011; UNICEF 2011). This developmental stage can involve intense and rapid transitions to new roles and responsibilities and may reflect a period of heightened vulnerability. Specifically, during puberty, adolescents may have their first sexual experiences, and in the case of girls, may become pregnant or married prematurely. In many countries, HIV, poverty, and political and social instability have impacted traditional support networks, such as families and communities, and may enhance risks of adolescents.

\subsection{Adolescents Not in School and Not Living with Parents}

Many young adolescents are not in school, not living with their parents, and/or married early and therefore may be at higher risk of negative outcomes. Out-of-school youth and those who do not reside with either parent can lack the familial and social support needed to buffer against societal pressures and to minimize the risk of exploitation.

2010 TDHS: Data in Table 11 show that 5\% of girls and 4\% of boys ages 10-14 who are out of school are not living with either parent. A higher percent of urban (8\%) relative to rural (4\%) females are not in school and not living with either parent, while for boys the urban to rural difference is marginal. The proportion for adolescent girls who are out of school and living with neither parent in urban environments is more than twice than that of boys. Higher proportions of adolescents who live in Mainland Tanzania as opposed to Zanzibar are neither in school nor living with either parent (5\% and $2 \%$ of females; $4 \%$ and $1 \%$ of males, respectively).

\begin{tabular}{|c|c|c|}
\hline \multicolumn{3}{|c|}{$\begin{array}{l}\text { Table 11: Percent of 10-14 Year Olds Not in School } \\
\text { and Not Living with Either Parent (DHS 2010) }\end{array}$} \\
\hline Region & Females & Males \\
\hline Mainland & 5.3 & 4.0 \\
\hline Zanzibar & 1.9 & 1.3 \\
\hline Urban & 8.1 & 3.1 \\
\hline Rural & 4.4 & 4.1 \\
\hline National & 5.2 & 3.9 \\
\hline \multicolumn{3}{|c|}{$\begin{array}{l}\text { Note: Read first data column as "Percent of 10-14 year old } \\
\text { females who are not in school and not living with either } \\
\text { parent," using } 2010 \text { TDHS. }\end{array}$} \\
\hline
\end{tabular}

Regions with the highest percent of females who are out of school and not living with either parent include: Arusha (10\%), Dar es Salaam (10\%), and Tabora (8\%) (see Annex Table 11). Regions with the highest percent of out-of-school males who are not living with either parent are: Lindi (9\%), Shinyanga (8\%), and Mwanza (7\%). 


\subsection{Illiteracy and Marriage before Age 15/18}

Limited education and other education-based indicators, such as illiteracy, have been correlated with early marriage (Population Council 2004). A greater proportion of girls who are married have limited education, as measured by the inability to read a sentence.

2010 TDHS: As Table 12 illustrates, 58\% of girls ages 15-24 who are married before age 15 are illiterate, compared to $12 \%$ of girls who have never been married. Small sample sizes limit the ability to robustly assess illiteracy among girls with early marriage by region (see Appendix Table 12); however, a higher percent of girls married before age 18 are illiterate who reside in rural (46\%) relative to urban (26\%) areas, and who reside in Mainland Tanzania (43\%) relative to Zanzibar (29\%).

\begin{tabular}{|c|c|c|c|}
\hline Region & $\begin{array}{c}\text { Married before } \\
\text { age } 15\end{array}$ & $\begin{array}{c}\text { Married before } \\
\text { age } 18\end{array}$ & Never-married \\
\hline Mainland & 58.8 & 42.5 & 12.3 \\
\hline Zanzibar & 25.3 & 29.0 & 6.1 \\
\hline Urban & * & 25.9 & 4.9 \\
\hline Rural & 64.0 & 45.8 & 16.3 \\
\hline National & 58.4 & 42.2 & 12.0 \\
\hline
\end{tabular}

\subsection{School Attendance, by Marital and Childbearing Status}

2010 TDHS: Table 13 presents results on current school attendance among females ages 15-19 by their marital and childbearing status. A higher percent of females who have never been married and have no child are currently attending school relative to those who have ever been married and/or have a child. Specifically, more than 50\% of never-married females ages 15-19 without a child are in school, compared to $0 \%$ of ever-married females with a child, $8 \%$ of never-married females with a child, and $1 \%$ of ever-married females without a child. Analysis by regional sub-group is limited by small sample sizes (see Annex Table 13).

\begin{tabular}{|c|c|c|c|c|}
\hline \multicolumn{5}{|c|}{$\begin{array}{l}\text { Table 13: Current School Attendance by Marital and Childbearing Status, } \\
\text { among Females Ages 15-19, Percent (DHS 2010) }\end{array}$} \\
\hline Region & $\begin{array}{l}\text { Ever-married } \\
\text { with a child }\end{array}$ & $\begin{array}{l}\text { Never- } \\
\text { married with } \\
\text { a child }\end{array}$ & $\begin{array}{l}\text { Ever-married } \\
\text { no child }\end{array}$ & $\begin{array}{l}\text { Never- } \\
\text { married no } \\
\text { child }\end{array}$ \\
\hline Mainland & 0.0 & 8.0 & 1.0 & 52.4 \\
\hline Zanzibar & 0.0 & * & * & 73.6 \\
\hline Urban & 0.0 & 23.4 & * & 59.3 \\
\hline Rural & 0.0 & 0.0 & 0.1 & 50.4 \\
\hline National & 0.0 & 7.9 & 1.1 & 53.4 \\
\hline \multicolumn{5}{|c|}{$\begin{array}{l}\text { Notes: Read first data column as "Percent of } 15-19 \text { year old ever-married females with } \\
\text { a child who attended school during the current school year" using } 2010 \text { TDHS; } \\
\text { Highlighted cells are based on } 25-50 \text { unweighted cases; Highlighted cells marked with } \\
\text { an asterisk are based on }<25 \text { unweighted cases and are suppressed. }\end{array}$} \\
\hline
\end{tabular}




\section{CONTEXT OF SEXUAL ACTIVITY}

The context in which young people experience sex is critical to analyzing adolescent reproductive health outcomes, particularly when considering that girls are vulnerable to forced sexual encounters (Hoffman et al. 2006; Plummer and Wight 2011). During adolescence, both males and females explore their sexuality in the context of gender norms, which are cultural or social ideals about how each gender should behave. Gender norms exist within a broader framework of parental and peer pressures about whether or not to engage in sex, to marry, or to bear children. Gender norms contribute to unequal power differentials in relationships, and may also sanction violence against women. They may influence the level of information, including awareness about sexual and reproductive health and rights, which is available to girls (Population Council 2004). This chapter presents data on some of the different contexts in which adolescent sexual activity occurs, and on selected reproductive health indicators.

\subsection{Age at First Marriage or Union among Females}

Tanzania, along with most countries, is a signatory to the Convention on the Elimination of All Forms of Discrimination Against Women and the Convention on the Rights of the Child, which state that the minimum age of marriage should be 18 years. Nevertheless, child marriage is deeply embedded in Tanzanian society, and continues at notable levels, with exceptional concentrations in specific regions. Child marriage undermines girls' access to education, limiting their wage-earning prospects and their ability to make informed decisions about their lives (UN CRC 2003). Early pregnancy may in turn leads to physical and emotional health risks for the mother, and poorer outcomes for her children (Clark et al. 2006).

Tables 14A and 14B present data on marriage from the TDHS and THMIS, respectively. Specifically, by age 15, between 7\% (TDHS) and 5\% (THMIS) of girls are married. By the age of 18 between $37 \%$ (TDHS) and 31\% (THMIS) and are married. There are clear differences in marriage among females ages 15-19 with urban-rural and Mainland-Zanzibar residence. Rural females are more than twice as likely to be married by age 18 , as compared to urban girls. Marriage by age 18 among Mainland females also exceeds those who reside in Zanzibar.

2010 TDHS: According to the TDHS, nationally $7 \%$ of females ages $20-24$ are married before age 15 , while $37 \%$ are married before age 18 . Regions with the highest percent of females ages $20-24$ who are married before age 15 are Dodoma, Lindi, Mara, Rukwa and Tabora. In each of these regions more than $10 \%$ of females ages $20-24$ are married before age 15 . Regions with the highest percent of females ages 20-24 who are married before age 18 are Dodoma, Mara, Shinyanga and Tabora. In each of these regions more than half of females ages 20-24 are married before age 18 .

2011-12 THMIS: Among females surveyed in the THMIS, 5\% of females ages 20-24 are married before age 15, while 31\% are married before age 18. Regions where percent of females ages 20-24 who are married before age 15 exceeds 10\% are Dodoma, Geita, Katavi, Mtwara, and Rukwa. Regions where more than $50 \%$ of females ages 20-24 who are married before age 18 are Katavi and Simiyu. 
Table 14A: Percent of Females Aged 2024 Years Married Before Ages 15 and 18 (DHS 2010)

\begin{tabular}{|c|c|c|}
\hline Region & $\begin{array}{c}\text { Married } \\
\text { before } \\
\text { age } 15\end{array}$ & $\begin{array}{c}\text { Married } \\
\text { before } \\
\text { age } 18\end{array}$ \\
\hline \multicolumn{3}{|l|}{ Mainland } \\
\hline Arusha & 7.2 & 27.3 \\
\hline Dar es Salaam & 5.7 & 18.6 \\
\hline Dodoma & 11.3 & 51.1 \\
\hline Iringa & 0.0 & 8.2 \\
\hline Kagera & 4.1 & 36.4 \\
\hline Kigoma & 6.4 & 25.5 \\
\hline Kilimanjaro & 6.4 & 26.6 \\
\hline Lindi & 12.9 & 47.7 \\
\hline Manyara & 8.3 & 33.7 \\
\hline Mara & 11.9 & 54.5 \\
\hline Mbeya & 7.6 & 45.0 \\
\hline Morogoro & 11 & 42.2 \\
\hline Mtwara & 2.1 & 35.2 \\
\hline Mwanza & 7.4 & 37.4 \\
\hline Pwani & 9.2 & 32.5 \\
\hline Rukwa & 11.4 & 40.0 \\
\hline Ruvuma & 4.4 & 39.2 \\
\hline Shinyanga & 3.4 & 58.8 \\
\hline Singida & 0.0 & 41.9 \\
\hline Tabora & 11.6 & 58.3 \\
\hline Tanga & 9.1 & 29.4 \\
\hline \multicolumn{3}{|l|}{ Zanzibar } \\
\hline Kaskazini Unguja & 3.3 & 23.6 \\
\hline Kusini Unguja & 3.3 & 18.6 \\
\hline Mjini Magharibi & 0.0 & 14.0 \\
\hline Kaskazini Pemba & 3.1 & 25.4 \\
\hline Kusini Pemba & 7.0 & 25.7 \\
\hline Mainland & 6.8 & 37.4 \\
\hline Zanzibar & 2.5 & 19.7 \\
\hline Urban & 4.2 & 22.5 \\
\hline Rural & 7.8 & 43.9 \\
\hline National & 6.6 & 36.9 \\
\hline \multicolumn{3}{|c|}{$\begin{array}{l}\text { Note: Read the first column of data as } \\
\text { “Percent of } 20-24 \text { year old females married } \\
\text { before age 15," using } 2010 \text { TDHS. } \\
\text { Highlighted cells are based on } 25-50 \\
\text { unweighted cases. }\end{array}$} \\
\hline
\end{tabular}

Table 14B: Percent of Females Aged 2024 Years Married Before Ages 15 and 18 (THMIS 2011-2012)

\begin{tabular}{|c|c|c|}
\hline Region & $\begin{array}{c}\text { Married } \\
\text { before } \\
\text { age } 15\end{array}$ & $\begin{array}{l}\text { Married } \\
\text { before } \\
\text { age } 18\end{array}$ \\
\hline \multicolumn{3}{|l|}{ Mainland } \\
\hline Arusha & 3.9 & 35.5 \\
\hline Dar es Salaam & 1.3 & 13.5 \\
\hline Dodoma & 17.9 & 44.6 \\
\hline Geita & 12.1 & 44.8 \\
\hline Iringa & 8.5 & 24.8 \\
\hline Kagera & 4.8 & 46.8 \\
\hline Katavi & 11.7 & 57.4 \\
\hline Kigoma & 2.5 & 18.4 \\
\hline Kilimanjaro & 0.0 & 8.9 \\
\hline Lindi & 6.2 & 39.0 \\
\hline Manyara & 4.2 & 21.7 \\
\hline Mara & 4.6 & 44.8 \\
\hline Mbeya & 2.4 & 25.2 \\
\hline Morogoro & 3.8 & 38.1 \\
\hline Mtwara & 14.1 & 47.8 \\
\hline Mwanza & 1.9 & 32.2 \\
\hline Njombe & 2.5 & 18.4 \\
\hline Pwani & 3.3 & 24.2 \\
\hline Rukwa & 14.3 & 39.8 \\
\hline Ruvuma & 4.3 & 24.3 \\
\hline Shinyanga & 9.2 & 45.5 \\
\hline Simiyu & 6.8 & 50.4 \\
\hline Singida & 1.3 & 12.5 \\
\hline Tabora & 9.3 & 43.3 \\
\hline Tanga & 6.2 & 31.0 \\
\hline \multicolumn{3}{|l|}{ Zanzibar } \\
\hline Kaskazini Unguja & 4.4 & 19.4 \\
\hline Kusini Unguja & 0.0 & 20.9 \\
\hline Mjini Magharibi & 3.3 & 13.7 \\
\hline Kaskazini Pemba & 6.0 & 29.3 \\
\hline Kusini Pemba & 2.9 & 24.2 \\
\hline Mainland & 5.4 & 31.6 \\
\hline Zanzibar & 3.5 & 18.0 \\
\hline Urban & 3.0 & 18.2 \\
\hline Rural & 6.2 & 35.9 \\
\hline National & 5.3 & 31.1 \\
\hline \multicolumn{3}{|c|}{$\begin{array}{l}\text { Note: Read the first column of data as } \\
\text { "Percent of 20-24 year old females married } \\
\text { before age 15," using 2011-12 THMIS. } \\
\text { Highlighted cells are based on 25-50 } \\
\text { unweighted cases }\end{array}$} \\
\hline
\end{tabular}

Annex Table 15 shows the incremental increase in percent of children married by age 15, 16, 17 and 18 , by region, respectively. 


\section{2. $\quad$ Age at First Sex}

In both the TDHS and THMIS, half or more of females ages 20-24 reported first having sex before the age of 18. While regional analysis for age of first sex varies by survey, in general young people who reside in rural and Mainland areas report transitioning to sexual activity at an earlier age relative to young people with residence in urban areas or in Zanzibar. Regions where there are consistently high reported rates of early sexual activity among females in both the TDHS and THMIS include Mtwara (for first sex before the age of 15) and Mara, Morogoro, Rukwa and Shinyanga (for first sex before the age of 18) (see Annex Tables 16A-1 and 16B). It should be noted that age at first sex (along with other sexual risk behaviours) may be under-reported given that adolescents may be reluctant to disclose these behaviours.

TDHS 2010: Tables 16A-1 and 16A-2 show the percent of females and males ages 20-24 who reported having had first intercourse before ages 15 and 18, respectively. A large percent of females ages 20-24 transitioned to sexual activity between the ages of 15 and 18 . Specifically, $14 \%$ of females ages 20-24 reported having had sex before age 15 and almost $60 \%$ reported this experience before age 18 . Of these girls, nearly one-third reported having had their first sexual experience at marriage.

In the surveys, males generally reported initiating sexual activity later in life than females (Table $16 \mathrm{~A}-2$ ). Only $6 \%$ of males ages $20-24$ reported having had sex before age 15 , and $40 \%$ reported this experience before the age of 18 (including those who reported first sexual experience at marriage). A substantially lower percent of males than females ages 20-24 reported having their first sexual experience at marriage ( $2 \%$ of males, compared to $32 \%$ of females).

\begin{tabular}{|c|c|c|c|}
\hline \multicolumn{4}{|c|}{ Table 16A-1: Sexual Initiation Before Ages 15 and 18, Among } \\
Females Ages 20-24, Percent (DHS 2010)
\end{tabular}

\begin{tabular}{|c|c|c|c|}
\hline \multicolumn{4}{|c|}{ Table 16A-2: Sexual Initiation Before Ages 15 and 18, Among } \\
Males Ages 20-24, Percent (DHS 2010)
\end{tabular}


2011-12 THMIS: Similar to the TDHS, data from the THMIS (Table 16B) also show that a large percent of females ages 20-24 have had sex before the age of 18 (48\%).

\begin{tabular}{|c|c|c|}
\hline \multicolumn{2}{|c|}{ Table 16B: Sexual Initiation by Ages 15 and 18, Among Females Ages 20- } \\
24, Percent THMIS (2011-2012)
\end{tabular}

\subsubsection{Age at First Sex by Household Wealth Quintile}

2010 TDHS: As data presented in Table 17 show, early sexual initiation does not appear to vary strongly by household wealth quintile. However, a lower percent of females ages 15-17 have transitioned to sexual activity before age 15 in the richest households (7\%), relative to the other quintiles.

\begin{tabular}{|c|c|c|}
\hline \multicolumn{3}{|c|}{$\begin{array}{c}\text { Table 17: Age At First Sex Among Females Ages 15-17, by } \\
\text { Household Wealth Quintile, Percent (DHS, 2010) }\end{array}$} \\
\hline $\begin{array}{l}\text { Household } \\
\text { Wealth Quintile }\end{array}$ & $\begin{array}{l}\text { First sex at or later } \\
\text { than age } 15\end{array}$ & $\begin{array}{l}\text { First sex before age } \\
15\end{array}$ \\
\hline Lowest & 89.0 & 11.0 \\
\hline Second & 85.7 & 14.3 \\
\hline Middle & 87.5 & 12.5 \\
\hline Fourth & 86.8 & 13.2 \\
\hline Highest & 92.7 & 7.3 \\
\hline \multicolumn{3}{|c|}{$\begin{array}{l}\text { Note: Read the first row and column of data as "Percent of } 15-17 \\
\text { year old females who had sex at or later than age } 15 \text { who reside in } \\
\text { the poorest households," using } 2010 \text { TDHS. }\end{array}$} \\
\hline
\end{tabular}

\subsection{Pregnancy and Childbearing among Females}

2010 TDHS: Data presented in Annex Table 18 show an increase in the likelihood of pregnancy with increasing age. Specifically, $5 \%$ of females aged 15 have ever been pregnant, while nearly all of females aged 24 (91\%) have ever been pregnant. The largest increase in females who have ever been pregnant occurs between ages the ages of 17 and 18, and between the ages of 19 and 20 (18\% increase, respectively). The likelihood of pregnancy is higher among females who reside in Mainland areas relative to Zanzibar. In general, rural females are also more likely to have ever been pregnant compared to those in urban areas. It should be noted that pregnancy data may be underreported given that adolescents may be reluctant to disclose a pregnancy. 


\subsubsection{Pregnancy Status by Household Wealth Quintile}

2010 TDHS: Annex Table 19 presents pregnancy status among females by household wealth quintile. Females who reside in wealthiest household are least likely to have ever been pregnant (7\%). In contrast, nearly one-fifth of females who reside in poorer households (19\%), and $15 \%$ of those in middle-income households, have ever been pregnant.

\subsubsection{Childbearing Before Ages 15 and 18 among Females}

2010 TDHS: Table 20 presents data on the percent of females ages 20-24 who have ever given birth before the ages of 15 and 18. Less than $10 \%$ of females ages $20-24$ have given birth before age $15(7 \%)$, while nearly half $(43 \%)$ have given birth before age 18 . Childbearing is higher among females who reside in Mainland and rural areas, relative to those who reside in Zanzibar or urban areas. The three regions with the highest percent of females who have ever given birth before age 15 are Arusha, Lindi and Morogoro (greater than 13\%). Regions with the highest percent of females who have ever given birth before age 18 are Dodoma, Lindi, Tabora (greater than 60\%).

\begin{tabular}{|c|c|c|}
\hline \multicolumn{3}{|c|}{$\begin{array}{c}\text { Table 20: Percent of 20-24 Year Old Females Who Ever Gave Birth } \\
\text { Before Ages } 15 \text { and } 18 \text { (2010 DHS) }\end{array}$} \\
\hline Region & Before Age 15 & Before Age 18 \\
\hline \multicolumn{3}{|l|}{ Mainland } \\
\hline Arusha & 13.4 & 36.9 \\
\hline Dar es Salaam & 5.4 & 26.2 \\
\hline Dodoma & 10.9 & 61.5 \\
\hline Iringa & 6.1 & 24.4 \\
\hline Kagera & 2.9 & 39.8 \\
\hline Kigoma & 8.6 & 34.9 \\
\hline Kilimanjaro & 11.7 & 28.9 \\
\hline Lindi & 15.2 & 60.8 \\
\hline Manyara & 3.8 & 26.5 \\
\hline Mara & 11.4 & 57.1 \\
\hline Mbeya & 6.3 & 48 \\
\hline Morogoro & 13.4 & 54.6 \\
\hline Mtwara & 4.1 & 54.2 \\
\hline Mwanza & 6.9 & 48.4 \\
\hline Pwani & 7.4 & 39.2 \\
\hline Rukwa & 5.0 & 43.4 \\
\hline Ruvuma & 5.3 & 52.4 \\
\hline Shinyanga & 4.7 & 54.7 \\
\hline Singida & 0.0 & 34.8 \\
\hline Tabora & 11.4 & 60.7 \\
\hline Tanga & 7.0 & 37.8 \\
\hline \multicolumn{3}{|l|}{ Zanzibar } \\
\hline Kaskazini Unguja & 4.2 & 15.9 \\
\hline Kusini Unguja & 4.6 & 20.2 \\
\hline Mjini Magharibi & 0.0 & 12.7 \\
\hline Kaskazini Pemba & 1.9 & 18.5 \\
\hline Kusini Pemba & 4.8 & 26.0 \\
\hline Mainland & 7.4 & 43.9 \\
\hline Zanzibar & 2.2 & 17.0 \\
\hline Urban & 6.2 & 31.5 \\
\hline Rural & 7.7 & 48.7 \\
\hline National & 7.2 & 43.0 \\
\hline
\end{tabular}




\subsection{Age Difference between Current Partners}

In many LMICs, the younger the age of a girl at marriage, the larger the age difference between the girl and her husband (Luke 2003). On average, the husbands of married girls are older than the partners of sexually active unmarried girls. A large age gap between girls and their partners or husbands may put those girls at a disadvantage in avoiding violence and in negotiating healthy sexual behaviour (Clark et al. 2006; LeClerc-Madlala 2008). The age difference between partnerswhether married or not-has implications for the woman's ability to negotiate voluntary, safe, and protected sexual relations (Population Council 2004). In addition, older men are likely to have had a higher number of lifetime sexual partners and to be HIV infected than younger women, increasing their younger partner's risk of exposure to the virus (Gregson et al. 2002; Hallet et al. 2010).

2011-12 THMIS: Table 21 shows that most females ages 15-24 (approximately 75\%) have partners within 0-4 and 5-9 years older than their own age. Results suggest females who have the most extreme age difference with their current partner (15 years or more) are more likely to live in Zanzibar rather than in Mainland areas of Tanzania, although data are limited by small sample sizes among females ages 15-19. A higher percent of females with a 15 or greater age year difference with their current partner live in rural rather than urban areas. This difference is more apparent among younger aged females.

Analysis of regional data is presented in Annex Table 21. Of areas with sufficient sample size, Dar es Salaam, Mara and Simiyu have notably high percents of females ages 20-24 with a greater than ten year age difference with their current partner ( $25 \%$ or greater).

\begin{tabular}{|c|c|c|c|c|c|c|c|c|}
\hline \multirow[b]{2}{*}{ Region } & \multicolumn{4}{|c|}{ Ages 15-19 } & \multicolumn{4}{|c|}{ Ages 20-24 } \\
\hline & $\begin{array}{c}\text { Partner } \\
0-4 \\
\text { years } \\
\text { older }\end{array}$ & $\begin{array}{c}\text { Partner } \\
5-9 \\
\text { years } \\
\text { older }\end{array}$ & $\begin{array}{c}\text { Partner } \\
10-14 \\
\text { years } \\
\text { older }\end{array}$ & $\begin{array}{c}\text { Partner } \\
15+ \\
\text { years } \\
\text { older }\end{array}$ & $\begin{array}{c}\text { Partner } \\
\text { 0-4 } \\
\text { years } \\
\text { older }\end{array}$ & $\begin{array}{c}\text { Partner } \\
5-9 \\
\text { years } \\
\text { older }\end{array}$ & $\begin{array}{c}\text { Partner } \\
10-14 \\
\text { years } \\
\text { older }\end{array}$ & $\begin{array}{c}\text { Partne } \\
15+ \\
\text { years } \\
\text { older }\end{array}$ \\
\hline Mainland & 33.0 & 40.3 & 17.2 & 9.6 & 36.7 & 38.7 & 13.6 & 11 \\
\hline Zanzibar & 16.8 & 52.8 & 3.2 & 27.2 & 40.5 & 28.5 & 11.1 & 19.9 \\
\hline Urban & 28.5 & 44.1 & 20.7 & 6.7 & 28.1 & 48.6 & 12.4 & 10.9 \\
\hline Rural & 33.4 & 39.9 & 16.5 & 10.2 & 39.1 & 35.8 & 13.8 & 11.4 \\
\hline National & 32.8 & 40.4 & 17.0 & 9.8 & 36.8 & 38.4 & 13.5 & 11.3 \\
\hline
\end{tabular}

\subsection{Gender Norms related to Domestic Violence}

Gender norms influence perceptions of the acceptability of using violence to control female decision-making, mobility, and activities, including sexual relations (Plummer and Wight 2011). Acceptance of the use of violence towards females early in life can lay a foundation for future unequal sexual relationships. Previous research has documented an association between acceptance of unequal gender norms and the experience of violence (Population Council 2004). Moreover, the adverse consequences of violence against females include an association with unintended pregnancy and HIV infection (Jewkes et al. 2010).

2010 TDHS: Table 22A shows that more than half (55\%) of females ages 15-24 agree with at least one justification for wife beating, while $11 \%$ believe that wife beating is completely justified (i.e., 
agree with all five reasons). Among surveyed reasons for wife beating, 39\% of females agreed that it was acceptable for a husband to beat his wife if she neglected the children, or if she argued with her husband.

The highest percent of females ages 15-24 who agreed with at least one justification for wife beating live in Kagera (82\%), Kigoma (81\%), and Mara (76\%). In contrast, girls in Zanzibar or Dar es Salaam have the lowest percent who agreed with at least one reason. See Annex Table 22A for additional data on gender norms surrounding domestic violence by region.

\begin{tabular}{|c|c|c|c|c|c|c|c|}
\hline Region & $\begin{array}{c}\text { If wife } \\
\text { goes out } \\
\text { without } \\
\text { telling } \\
\text { husband }\end{array}$ & $\begin{array}{c}\text { If wife } \\
\text { neglects } \\
\text { children }\end{array}$ & $\begin{array}{l}\text { If wife } \\
\text { argues } \\
\text { with } \\
\text { husband }\end{array}$ & $\begin{array}{l}\text { If wife } \\
\text { refuses } \\
\text { to have } \\
\text { sex with } \\
\text { husband }\end{array}$ & $\begin{array}{l}\text { If wife } \\
\text { burns } \\
\text { the food }\end{array}$ & $\begin{array}{c}\text { Percent } \\
\text { who said } \\
\text { yes to at } \\
\text { least one } \\
\text { reason }\end{array}$ & $\begin{array}{l}\text { Agreed } \\
\text { with all } \\
\text { five } \\
\text { reasons }\end{array}$ \\
\hline Mainland & 35.4 & 39.6 & 39.6 & 25.8 & 17.4 & 56.2 & 10.8 \\
\hline Zanzibar & 22.4 & 18.7 & 16.4 & 13.8 & 4.7 & 29.8 & 4.3 \\
\hline Urban & 27.4 & 32.7 & 32.1 & 16.3 & 10.2 & 46.1 & 6.2 \\
\hline Rural & 38.3 & 41.7 & 41.9 & 29.5 & 20.0 & 59.5 & 12.7 \\
\hline National & 34.9 & 38.9 & 38.8 & 25.4 & 17.0 & 55.3 & 10.6 \\
\hline
\end{tabular}

Agreement with justifications for wife beating is slightly lower among same aged males (Table 22B). Specifically, half of males ages 15-24 agreed with at least one justification for wife beating, while only $3 \%$ agreed with all five surveyed reasons. The reason with the highest agreement among males was also if the wife neglected the children (28\%), followed by if the wife goes out without telling her husband (24\%). Examination of regional variation among males was limited by small sample sizes (see Annex Table 22B). More rural than urban males (55\% and 35\%) agreed with at least one justification for wife beating or all five reasons ( $5 \%$ rural vs. $<1 \%$ urban).

Table 22B: Percent of Males Ages 15-24 Who Agree It Is Acceptable for Husband to Beat Wife (DHS, 2010)

\begin{tabular}{|c|c|c|c|c|c|c|c|}
\hline Region & $\begin{array}{c}\text { If wife } \\
\text { goes out } \\
\text { without } \\
\text { telling } \\
\text { husband }\end{array}$ & $\begin{array}{c}\text { If wife } \\
\text { neglects } \\
\text { children }\end{array}$ & $\begin{array}{c}\text { If wife } \\
\text { argues } \\
\text { with } \\
\text { husband }\end{array}$ & $\begin{array}{c}\text { If wife } \\
\text { refuses } \\
\text { to have } \\
\text { sex with } \\
\text { husband }\end{array}$ & $\begin{array}{c}\text { If wife } \\
\text { burns } \\
\text { the food }\end{array}$ & $\begin{array}{c}\text { who said } \\
\text { yes to at } \\
\text { least one } \\
\text { reason }\end{array}$ & $\begin{array}{c}\text { Agreed } \\
\text { with all } \\
\text { five } \\
\text { reasons }\end{array}$ \\
\hline Mainland & 24.1 & 27.9 & 22.6 & 11.3 & 6.6 & 50.7 & 3.3 \\
\hline Zanzibar & 15.5 & 14.0 & 11.1 & 13.7 & 3.5 & 28.7 & 3.1 \\
\hline Urban & 12.5 & 19.5 & 12.3 & 4.8 & 1.3 & 35.0 & 0.1 \\
\hline Rural & 28.0 & 30.4 & 25.9 & 13.8 & 8.4 & 55.4 & 4.6 \\
\hline National & 23.8 & 27.5 & 22.3 & 11.4 & 6.5 & 50.0 & 3.3 \\
\hline $\begin{array}{l}\text { Note: Read the first column of data as “Percent of 15-24 year old males who agree that wife beating is } \\
\text { justified if the wife goes out without telling her husband," using 2010 TDHS. }\end{array}$
\end{tabular}




\section{EXPOSURE TO VIOLENCE}

An increasing body of research has highlighted the health burdens, intergenerational effects, and social and emotional consequences of violence (Panos Institute 2003; Andersson et al. 2008; Campbell et al. 2008). While women bear the brunt of domestic violence and its physiological and health consequences, violence against adolescents has been less documented (Wood et al. 1998). In many societies, including Tanzania, some victims of violence are socialized to accept, tolerate and even rationalize violence (Wood et al. 2007; Plummer and Wight 2011). Experiencing violence at an early age also can have negative implications for a healthy transition into adulthood. In particular, exposure to childhood violence is associated with sexual risk-taking in adolescence and adulthood (Arriola et al. 2005; Hoffman et al. 2006; Gwandure 2007).

The cultural silence and sensitive nature of violence makes data collection particularly challenging. The 2010 TDHS and 2009 VACS both included questions on experiences of violence. Specifically, the 2010 TDHS interviewed women (ages 15 and older) on experiences of domestic violence occurring within the household. The 2009 VACS also asked males and females (ages 13 to 24) to report on exposure to violence. Both surveys undertook steps to ensure confidentiality and privacy during the interview necessary for the validity of collected data, as well as the security of respondents. However, questions included in the VACS related to violence were both more broadly and more specifically defined, allowing for inclusion of more experiences. In addition, VACS questions were preceded by comments to the respondent on steps taken to ensure confidentiality and the importance of truthful responses, and interviews involved more in-depth probing, both of which may have facilitated reporting. As a result, the VACS found a much higher prevalence of reported violence than the TDHS. Further details on the collection of data related to violence are provided in the final reports of each survey (see Technical Notes, page 1). Despite all of the above measures, the possibility of underreporting of violence cannot be ruled out in any survey.

\section{1. $\quad$ Forced First Sex}

Understanding the first sexual experience of girls and boys is important as it has been linked with future reproductive health outcomes (Pettifor et al. 2004).

2010 TDHS: $12 \%$ of sexually experienced females ages 15-19 reported that their first intercourse was forced and against their will (Table 23A). Specifically, they were asked, "The first time you had sexual intercourse, would you say that you had it because you wanted to, or because you were forced to have it against your will?" Among sexually experienced females ages 15-19, the percent whose first sex was forced is higher among females in Mainland Tanzania relative to Zanzibar and in rural areas relative to urban areas. Among females ages 20-24, nearly one in ten (9\%) report their first sex was forced. This percent does not differ appreciably by Mainland-Zanzibar or urban-rural residence. 


\begin{tabular}{|c|c|c|}
\hline \multicolumn{3}{|c|}{$\begin{array}{c}\text { Table 23A: Percent of Sexually Experienced Females Who } \\
\text { Were Forced at Sexual Initiation, by Age (DHS 2010) }\end{array}$} \\
\hline Region & Ages 15-19 & Ages 20-24 \\
\hline Mainland & 11.9 & 8.8 \\
\hline Zanzibar & 6.6 & 7.6 \\
\hline Urban & 8.5 & 9.8 \\
\hline Rural & 13.1 & 8.3 \\
\hline National & 11.9 & 8.8 \\
\hline
\end{tabular}

Note: Read the first column of data as "Percent of 15-19 year old females who ever had sex who say that their first experience of sexual intercourse was forced against their will," using 2010 TDHS. Figures in highlighted cells are based on 25-50 unweighted cases.

2009 VACS: The 2009 VACS also surveyed sexually experienced young people on whether their first sexual intercourse was forced by asking if during their first sex they "wanted sex, or were forced, pressurized, deceived, or threatened in any way" (Table 23B). A substantial percent of sexually experienced females and males ages 15-24 report their first sex was unwanted in one or more of these ways. Specifically, $28 \%$ or more of females and $19 \%$ of males ages $15-19$ reported this. Similar to findings in the 2010 TDHS, a sizeable, but slightly lower percent of sexually experienced young people ages $20-24$ report their first sex was forced (25\% of females; $15 \%$ of males).

Table 23B: Percent of Sexually Experienced Females and Males Who Were Forced, Pressurised, Deceived, or Threatened at Sexual Initiation, by Age (VACS 2009)

\begin{tabular}{|c|c|c|c|c|}
\hline \multirow{2}{*}{ Region } & \multicolumn{2}{|c|}{ Females } & \multicolumn{2}{c|}{ Males } \\
\cline { 2 - 5 } & Ages 15-19 & Ages 20-24 & Ages 15-19 & Ages 20-24 \\
\hline Mainland & 28.2 & 24.8 & 19.1 & 15.1 \\
\hline Zanzibar & 14.2 & 10.8 & 9.1 & 4.3 \\
\hline National & 28.1 & 24.6 & 19.0 & 15.0 \\
\hline
\end{tabular}

Note: Read the first column of data as "Percent of 15-19 year old females who ever had sexual intercourse who say that they were forced, pressurized, deceived, or threatened at first sexual intercourse," using 2009 VACS. Figures in highlighted cells are based on 25-50 unweighted cases.

In subsequent presentation of data here, the VACS category of 'forced, pressured, deceived, or threatened' will be written simply as 'forced'.

\subsubsection{Age of First Forced Sex}

Tables 24A and 24B1-2 present data on the age at which young people experienced force at their sexual initiation. Due to differences in indicator construction, results from the two surveys are not directly comparable. Specifically, TDHS data show the age of first forced sex among females who experienced force at sexual initiation, while VACS data show the age of first forced sex among all sexually experienced adolescents. Replicating the TDHS indicator construction was not possible in the VACS dataset due to smaller sample size and lower relative number of adolescents who experienced force at sexual initiation. Taken together, however, data indicate a sizeable percent of young people experience forced sexual initiation at an early age.

2010 DHS: Table 24A shows that, among females ages 15-19 who have experienced forced sex at sexual initiation, the vast majority of experiences occurred at or before the age of 18 (81\%), while approximately one-quarter occurred at or before age 15 (27\%). Among females ages 20-24 who experienced forced sex at sexual initiation, a slightly lower percent had the experience by the age of $15(23 \%)$ while a little over half (55\%) had the experience by the age of 18. 


\begin{tabular}{|c|c|c|c|c|}
\hline \multicolumn{5}{|c|}{ Table 24A: Among Females Ages 15-24 Years Whose First Sex was Forced, Percent For Whom It } \\
Occurred by Ages 15 and 18 (DHS 2010) \\
\hline \multirow{2}{*}{ Region } & \multicolumn{2}{|c|}{ By Age 15 } & \multicolumn{2}{c|}{ By Age 18 } \\
\cline { 2 - 5 } & Ages 15-19 & Ages 20-24 & Ages 15-19 & Ages 20-24 \\
\hline Mainland & 27.0 & 23.2 & 80.7 & 54.9 \\
\hline Zanzibar & $\star$ & $\star$ & $*$ & * \\
\hline Urban & 34.7 & 18.5 & 80.4 & 53.1 \\
\hline Rural & 24.5 & 26 & 80.9 & 54.7 \\
\hline National & 27.1 & 23.2 & 80.7 & \\
\hline
\end{tabular}

Note: Read the first column of data as "Among females ages 15-19 who say that their first experience of sexual intercourse was forced against their will, percent that experienced forced sex by age 15" using 2010 DHS. Figures in highlighted cells are based on 25-50 unweighted cases; Highlighted figures with asterisk are based on less than 25 unweighted cases and have been suppressed.

2009 VACS: Tables 24B1-2 show the percent of adolescents whose first sex was forced by ages 15 or 18 , among all sexually experienced adolescents. Specifically, $13 \%$ of females and $8 \%$ of males ages 15-19 reported their first sexual intercourse was forced at or before age 15; while about onequarter (26\%) of females and nearly one-fifth (18\%) of males reported their first intercourse was forced at or before age 18.

Table 24B-1: Among All Sexually Experienced Females, Percent Whose First Sex was Forced by Age 15 or 18 (VACS 2009)

\begin{tabular}{|c|c|c|c|c|}
\hline \multirow{2}{*}{ Region } & \multicolumn{2}{|c|}{ First Forced Sex by Age 15 } & \multicolumn{2}{c|}{ First Forced Sex by Age 18 } \\
\cline { 2 - 5 } & Ages 15-19 & Ages 20-24 & Ages 15-19 & Ages 20-24 \\
\hline Mainland & 13 & 8.9 & 25.8 & 19.1 \\
\hline Zanzibar & 0.9 & 0.8 & 14.2 & 4.4 \\
\hline National & 12.9 & 8.7 & 25.7 & 18.9 \\
\hline
\end{tabular}

Notes: Read the first column of data as "Percent of females ages 15-19 who say that their first experience of sexual intercourse was forced against their will at or before age 15, among adolescents who are sexually experienced" using 2009 VACS. Figures in highlighted cells are based on 25-50 unweighted cases.

Table 24B-2: Among All Sexually Experienced Males, Percent Whose First Sex was Forced by Ages 15 or 18 (VACS 2009)

\begin{tabular}{|c|c|c|c|c|}
\hline \multirow{2}{*}{ Region } & \multicolumn{2}{|c|}{ First Forced Sex by Age 15 } & \multicolumn{2}{c|}{ First Forced Sex by Age 18 } \\
\cline { 2 - 5 } & Ages 15-19 & Ages 20-24 & Ages 15-19 & Ages 20-24 \\
\hline Mainland & 7.8 & 1.3 & 18.0 & 12.1 \\
\hline Zanzibar & 7.7 & 0.0 & 7.7 & 1.1 \\
\hline National & 7.8 & 1.3 & 17.8 & 12.0 \\
\hline
\end{tabular}

Notes: Read the first column of data as "Percent of males ages 15-19 who say that their first experience of sexual intercourse was forced against their will at or before age 15, among adolescents who are sexually experienced" using 2009 VACS. Figures in highlighted cells are based on 25-50 unweighted cases.

\subsubsection{Perpetrators of First Forced Sex}

2010 TDHS: Table 25A presents data on the persons reported to have forced a woman's first sexual experience against her will. Among females who reported this, most said that someone other than their current or former spouse, live-in partner, boyfriend, or relative perpetrated the act. The likelihood that a woman reported that her current or former spouse was the perpetrator of her first forced sex increased with age (from $7 \%$ of females ages $15-17$, to $26 \%$ of females ages $20-24$ ), whereas the likelihood of some 'other' person committing forced sex decreased with age (from $64 \%$ among females ages $15-17$, to 31\% among females ages $20-24$ ). 
Table 25A: Among Females Whose First Intercourse was Forced, Percent of Perpetrators Reported to be Partner, Relative, or Other (DHS 2010)

\begin{tabular}{|c|c|c|c|c|}
\hline Ages & Spouse & Boyfriend & Relative & Other person \\
\hline $15-17$ & 6.6 & 13.2 & 9.1 & 64.1 \\
\hline $18-19$ & 15.3 & 21.5 & 12.6 & 39.3 \\
\hline $15-19$ & 10.2 & 16.6 & 10.6 & 53.9 \\
\hline $20-24$ & 25.9 & 19.6 & 0.4 & 30.9 \\
\hline
\end{tabular}

Notes: Read the first column of data as "Among all females ages 15-17 who report that their first experience of sexual intercourse was forced, percent who say the perpetrator was their spouse" using 2010 DHS. Percents do not sum to $100 \%$ because not all respondents provided full information on perpetrators.

2009 VACS: Adolescent reports of type of perpetrator are limited by small sample sizes and are presented in Annex Tables 25B1-2.

\subsection{Ever Experience Sexual Violence}

Both the TDHS and VACS asked respondents if they had ever experienced sexual violence. The prevalence of reported sexual violence differs by survey and reflects variation in how questions related to sexual violence were asked, in addition to different dates of data collection and surveyed respondents. Nonetheless, both surveys found that a sizeable percent of females and males experience sexual violence during adolescence, and that that possibility increases with age. VACS data in particular indicate that a higher proportion of females experience sexual violence by ages $15-17$ relative to males ( $36 \%$ vs. $16 \%$ ).

2010 TDHS: In addition to investigating if a female's first sexual intercourse was forced against her will, the 2010 TDHS asked questions about whether sexual acts were ever forced by a woman's current husband or partner (if she was currently married), or by her most recent husband or partner (if she was currently divorced, separated, or widowed). A second question asked all women whether she ever, as a child or as an adult, was forced to have sexual intercourse or to perform any other sexual acts against her will. Table 26A shows that 13\% of females ages 15-19 had experienced such sexual violence (including first forced sex). The likelihood of experiencing sexual violence increases with a female's age, from $11 \%$ of $15-17$ year olds to $19 \%$ of $20-24$ year olds.

\begin{tabular}{|c|c|c|c|c|}
\hline Region & Ages 15-17 & Ages 18-19 & Ages 15-19 & Ages 20-24 \\
\hline Mainland & 11.2 & 17.9 & 13.6 & 18.9 \\
\hline Zanzibar & 2.3 & 3.3 & 2.7 & 9.8 \\
\hline Urban & 10.5 & 11.2 & 10.7 & 19.5 \\
\hline Rural & 11 & 20.1 & 14.2 & 18.1 \\
\hline National & 10.8 & 17.4 & 13.2 & 18.6 \\
\hline \multicolumn{5}{|c|}{$\begin{array}{l}\text { Notes: Read the first column of data as "Percent of } 15-17 \text { year old females who ever } \\
\text { experienced sexual violence," using } 2010 \text { TDHS. } \\
\text { a 'Sexual violence' includes: sexual violence by husband/partner; ever forced to perform } \\
\text { unwanted sexual acts by anyone; ever forced to have sex by anyone other than current partner } \\
\text { in past } 12 \text { months; and first sex was forced by anyone. }\end{array}$} \\
\hline
\end{tabular}

Regions with more than 20\% of females ages 15-19 reporting sexual violence include Iringa, Kagera, Kigoma, Mara, Mbeya, Morogoro and Ruvuma (greater than 20\%). Among females ages 2024, more than 20\% reported this in Dar es Salaam, Kagera, Kigoma, Mara, Mbeya, Mwanza, Rukwa, Ruvuma and Singida (see Annex Table 26A). 
2009 VACS: The VACS defines 'sexual violence' as any sexual act perpetrated against someone's will, including: (1) unwanted touching in a sexual way; (2) attempted unwanted intercourse; (3) physically forced intercourse; and (4) coerced intercourse, in which the respondent was pressured or threatened in a non-physical way against his or her will. Specifically, respondents were asked how many times, since s/he was born did, "(1) a male or female person touch you sexually although $\mathrm{s} /$ he did not force you to have sexual intercourse; (2) anyone tried to make you have sex against your will but did not succeed; (3) you were physically forced to have sex against your will and the sex was completed; and (4) someone forced you to have sex that was completed when you actually did not want to have sex". Each of these questions is preceded by a detailed description of what constitutes "unwanted touching", "forced", or "coerced" sex. Data from the VACS (Table 26B-1) show that nearly 4 out of 10 females ages 15-19 reported experiencing at least one incident of such sexual violence. Among males of the same age, nearly 2 in 10 reported experiencing one incident of sexual violence (Table 26B-2).

Similar to TDHS findings, the likelihood of ever experiencing sexual violence increased with age, particularly among boys, from $16 \%$ of $15-17$ year olds to $30 \%$ of $20-24$ year olds. For females, sexual violence generally occurred earlier. Among females ages 15-17, 36\% had ever experienced sexual violence, while by ages $20-24,40 \%$ reported at least one incident. Importantly, in Zanzibar, higher rates of sexual violence were reported among males compared to females, but overall, reported rates of sexual violence were higher in Mainland compared to Zanzibar.

\begin{tabular}{|c|c|c|c|c|}
\hline \multicolumn{5}{|c|}{ Table 26B-1: Percent of Females Who Ever Experienced Sexual Violence ${ }^{\text {a }}$, by Age } \\
(VACS 2009) & Ages 20-24 15-19 & Ages \\
\hline Region & Ages 15-17 & Ages 18-19 & Ages 15 & 40.5 \\
\hline Mainland & 36.5 & 40.5 & 38.1 & 12.6 \\
\hline Zanzibar & 5.6 & 13.1 & 8.6 & 39.7 \\
\hline National & 35.6 & 39.7 & 37.3 & \\
\hline
\end{tabular}

Note: Read the first column of data as "Percent of 15-17 year old females who have ever experienced sexual violence," using 2009 VACS.

a 'Sexual violence' includes: sexual violence by husband/partner; ever forced to perform unwanted sexual acts by anyone; ever forced to have sex by anyone other than current partner in past 12 months; and first sex was forced by anyone

\begin{tabular}{|c|c|c|c|c|}
\hline \multicolumn{5}{|c|}{$\begin{array}{l}\text { Table 26B-2: Percent of Males Who Ever Experienced Sexual Violence }{ }^{\text {, by Age }} \\
\text { (VACS 2009) }\end{array}$} \\
\hline Region & Ages 15-17 & Ages 18-19 & Ages 15-19 & Ages 20-24 \\
\hline Mainland & 16.3 & 22.5 & 18.6 & 29.9 \\
\hline Zanzibar & 12.2 & 11.8 & 12.0 & 20.9 \\
\hline National & 16.1 & 22.1 & 18.4 & 29.6 \\
\hline
\end{tabular}

Note: Read the first column of data as "Percent of 15-17 year old males who have ever experienced sexual violence," using 2009 VACS.

a 'Sexual violence' includes: sexual violence by husband/partner; ever forced to perform unwanted sexual acts by anyone; ever forced to have sex by anyone other than current partner in past 12 months; and first sex was forced by anyone

\subsection{Experience of Physical Violence}

Both the TDHS and the VACS found that a substantial percent of young people who have ever experienced physical violence, although, as with measures of sexual violence, there is large variability in the prevalence of reported physical violence due to differences in question wording, survey samples, and dates of data collection. Despite such differences, both surveys found that a higher percent of females ages 15 to 24 years on the Mainland than in Zanzibar reported experience of physical violence. For males, experiences of physical violence was higher among 
Mainland ages 15-19, but was higher in Zanzibar among males ages 20-24. Survey specific methodology and findings are discussed below.

2010 TDHS: The TDHS asked women if they ever experienced an incident of physical violence by their current or former spouse since the age of 15 . Spousal violence was measured by asking evermarried women if their current or former spouse ever did the following: pushed/shook her; threw something; slapped her; twisted her arm; pulled her hair; kicked/dragged her; beat her; tried to choke her; burned her on purpose; threatened her with a weapon; or forced her to have unwanted sexual intercourse or other sexual acts. In addition to spousal violence, women were asked if they had experienced violence at the hands of anyone other than their current or last husband using the question: "From the time you were 15 years old, has anyone (other than your current/last husband) hit, slapped, kicked, or done anything else to hurt you physically?"

Results presented in Table 27A present data on women who responded 'yes' to either question on physical violence. Nearly one-quarter of females ages 15-19 had experienced spousal violence or physical violence from another person since the age of 15 . The prevalence of physical violence increases with age. By ages 20-24, 37\% of females have experienced physical violence.

\begin{tabular}{|c|c|c|c|c|}
\hline \multicolumn{5}{|c|}{$\begin{array}{l}\text { Table 27A: Percent of Females Who Ever Experienced Physical Violencea (DHS } \\
2010)\end{array}$} \\
\hline Region & Ages 15-17 & Ages 18-19 & Ages 15-19 & Ages 20-24 \\
\hline Mainland & 20.7 & 30.0 & 24.1 & 38.4 \\
\hline Zanzibar & 5.4 & 13.4 & 8.4 & 9.8 \\
\hline Urban & 18.7 & 29.5 & 22.8 & 37.6 \\
\hline Rural & 20.7 & 29.4 & 23.8 & 37.4 \\
\hline Zanzibar & 4.6 & 5.3 & 4.9 & 9.2 \\
\hline National & 20.1 & 29.4 & 23.5 & 37.4 \\
\hline
\end{tabular}

There are notable variations in the prevalence of physical violence by region (Annex Table 27A). In four regions, experiences of physical violence among females ages 15-19 exceeds 35\%: Dodoma (49\%), Kagera (37\%), Mara (41\%) and Morogoro (47\%). By contrast, Kaskazini Pemba has the lowest prevalence of physical violence among females ages 15-19 (2\%).

2009 VACS: The 2009 VACS measured physical violence among young people by asking all respondents if they had been: (1) slapped, pushed, hit with a fist, kicked, or whipped; or (2) threatened with a weapon, such as a gun or a knife. Specifically, respondents were asked if either type of violence was ever committed by the following individuals: a current/former lover; a parent or adult relative; or an authority figure (i.e., teacher, police, religious leader, soldier or other authoritative leader). Tables 27B1-2 show that $81 \%$ of females and $80 \%$ of males ages $15-19$ reported experiences of such physical violence. A large, but slightly lower, percent of young people ages 20-24 also reported having experienced physical violence ( $67 \%$ of females and $63 \%$ of males). 


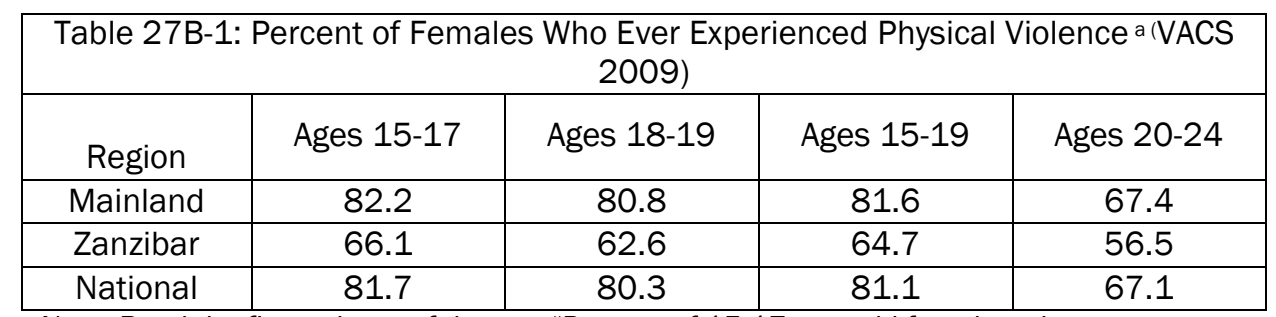

Note: Read the first column of data as "Percent of 15-17 year old females who ever experienced physical violence," using 2009 VACS.

a Physical violence' includes violence by a current or former spouse, or physical violence from someone else since the age of 15.

\begin{tabular}{|c|c|c|c|c|}
\hline \multicolumn{5}{|c|}{ Table 27B-2: Percent of Males Who Ever Experienced Physical Violence ${ }^{\text {a }}$} \\
(VACS 2009) \\
Region & Ages 15-17 & Ages 18-19 & Ages 15-19 & Ages 20-24 \\
\hline Mainland & 77.4 & 85.0 & 80.3 & 62.6 \\
\hline Zanzibar & 70.9 & 69.0 & 70.1 & 72.1 \\
\hline National & 77.2 & 84.5 & 80.0 & 62.9 \\
\hline
\end{tabular}

Note: Read the first column of data as "Percent of 15-17 year old males who ever experienced physical violence," using 2009 VACS.

a Physical violence' includes violence by a current or former spouse, or physical violence from someone else since the age of 15.

\subsection{Combinations of Violence Experienced}

Tables 28A and 28B1-2 show the percent of young people who have experienced different combinations of physical and sexual violence, by age, according to the 2010 TDHS and 2009 VACS. The prevalence of different forms of violence varies largely between the two surveys, reflecting the differences in data collection and methodology previously described. Overall, experience of physical and/or sexual violence is higher among Mainland females than Zanzibar females. This trend is also evident among males, except that males ages 20-24 have a higher reported experience of physical violence in Zanzibar relative to Mainland areas.

2010 TDHS: Almost one-third of females ages 15-19 (30\%) and 44\% of females ages 20-24 have experienced either physical or sexual violence. The likelihood of having experienced any form of violence increases with age, from $26 \%$ of females ages $15-17$, to $44 \%$ of females ages $20-24 \%$ (see Annex Table 28A). The prevalence of sexual and/or physical violence does not vary substantially according to urban or rural residence among females. Both types of violence are lower among females in Zanzibar relative to Mainland areas.

More than $10 \%$ of females ages 15-19 report experiences of both physical and sexual violence in four regions: Kagera, Mara, Morogoro, and Ruvuma (Annex 28A). Morogoro has the highest percent at $22 \%$ of females ages $15-19$. The regions where at least $20 \%$ of females ages $20-24$ report both types of violence are Mara (32\%), followed by Mbeya (26\%), Kagera (25\%) and Ruvuma (21\%). 
Table 28A: Types of Violence Ever Experienced among Females Ages 15-24, Percent (DHS 2010)

\begin{tabular}{|c|c|c|c|c|c|c|c|c|}
\hline \multirow{2}{*}{ Region } & \multicolumn{2}{|c|}{ Physical violencea only } & \multicolumn{2}{|c|}{ Sexual violence ${ }^{\mathrm{b}}$ only } & \multicolumn{2}{|c|}{$\begin{array}{c}\text { Sexual or physical } \\
\text { violence }\end{array}$} & \multicolumn{2}{|c|}{$\begin{array}{c}\text { Sexual and physical } \\
\text { violence }\end{array}$} \\
\hline & $\begin{array}{l}\text { Ages } \\
15-19\end{array}$ & $\begin{array}{l}\text { Ages } \\
20-24\end{array}$ & $\begin{array}{l}\text { Ages } \\
15-19\end{array}$ & $\begin{array}{l}\text { Ages } \\
20-24\end{array}$ & $\begin{array}{l}\text { Ages } \\
15-19\end{array}$ & $\begin{array}{l}\text { Ages } \\
20-24\end{array}$ & $\begin{array}{l}\text { Ages } \\
15-19\end{array}$ & $\begin{array}{l}\text { Ages } \\
20-24\end{array}$ \\
\hline Mainland & 17.1 & 25.9 & 6.6 & 6.3 & 30.7 & 44.8 & 7.0 & 12.6 \\
\hline Zanzibar & 7.1 & 7.5 & 1.4 & 7.5 & 9.8 & 17.3 & 1.3 & 2.3 \\
\hline Urban & 16.9 & 25.9 & 4.8 & 7.8 & 27.6 & 45.4 & 5.9 & 11.7 \\
\hline Rural & 16.7 & 24.9 & 7.1 & 5.7 & 30.9 & 43.1 & 7.1 & 12.4 \\
\hline National & 16.7 & 25.2 & 6.4 & 6.4 & 29.9 & 43.8 & 6.8 & 12.2 \\
\hline
\end{tabular}

Notes: Read the first column of data as "Percent of 15-19 year old females who ever experienced physical violence but not sexual violence," using 2010 DHS.

a 'Physical violence' includes violence by current/former spouse, or physical violence from someone other than spouse since the age of 15. ' 'Sexual violence' includes sexual violence by husband/partner; ever forced to perform unwanted sexual acts by anyone; ever forced to have sex by anyone other than current partner in past 12 months; and first sex was forced by anyone.

2009 VACS: Tables 28B-1 and 28B-2 show that the large majority of females ages 15-19 (84\%) and ages 20-24 (76\%) have experienced either physical or sexual violence, while approximately one-third of females ages 15-19 (33\%) and 20-24 (30\%) have experienced both forms of violence. An equally high percent of males ages 15-19 (81\%) and 20-24 (70\%) report experiencing sexual or physical violence, while $15 \%$ of males ages $15-19$, and $22 \%$ of those ages $20-24$, have experienced both forms.

As as found in the TDHS, Mainland females have higher reported rates of both forms of violence. Mainland-Zanzibar discrepancies are notably larger for physical violence and for having experienced both sexual and physical violence. Specifically, over one-third (34\%) of females ages 15-19 report experiencing both physical and sexual violence, compared to $5 \%$ of those in Zanzibar. This trend is also observed among males ages 15-19. Specifically, the percent of males ages 15-19 experiencing both forms of violence is nearly double in Mainland areas (16\%) relative to Zanzibar (9\%). For males ages 20-24, there is less difference between Mainland-Zanzibar prevalences.

\begin{tabular}{|c|c|c|c|c|c|c|c|c|}
\hline & 281 & Viol & Ex & am & ales & 24, P & ACS & \\
\hline \multirow{2}{*}{ Region } & \multicolumn{2}{|c|}{ Physical violence ${ }^{a}$ only } & \multicolumn{2}{|c|}{ Sexual violence ${ }^{b}$ only } & \multicolumn{2}{|c|}{$\begin{array}{c}\text { Sexual or physical } \\
\text { violence }\end{array}$} & \multicolumn{2}{|c|}{$\begin{array}{c}\text { Sexual and physical } \\
\text { violence }\end{array}$} \\
\hline & $\begin{array}{l}\text { Ages } \\
15-19\end{array}$ & $\begin{array}{c}\text { Ages } \\
20-24\end{array}$ & $\begin{array}{c}\text { Ages } \\
15-19\end{array}$ & $\begin{array}{c}\text { Ages } \\
20-24\end{array}$ & $\begin{array}{c}\text { Ages } \\
15-19\end{array}$ & $\begin{array}{l}\text { Ages } \\
20-24\end{array}$ & $\begin{array}{l}\text { Ages } \\
15-19\end{array}$ & $\begin{array}{c}\text { Ages } \\
20-24\end{array}$ \\
\hline Mainland & 46.7 & 35.1 & 3.5 & 9.6 & 84.9 & 76.4 & 34.3 & 30.2 \\
\hline Zanzibar & 58.6 & 47.9 & 3.2 & 4.2 & 67.5 & 60.5 & 5.3 & 8.3 \\
\hline National & 47.1 & 35.4 & 3.5 & 9.4 & 84.4 & 76.0 & 33.4 & 29.6 \\
\hline
\end{tabular}

Note: Read the first column of data as "Percent of 15-19 year old females who have ever experienced physical violence but not sexual violence," using 2009 VACS.

a 'Physical violence' includes violence by current/former spouse, or physical violence from someone other than spouse since the age of 15. ' 'Sexual violence' includes sexual violence by husband/partner; ever forced to perform unwanted sexual acts by anyone; ever forced to have sex by anyone other than current partner in past 12 months; and first sex was forced by anyone.

\begin{tabular}{|c|c|c|c|c|c|c|c|c|}
\hline \multirow{2}{*}{ Region } & \multicolumn{2}{|c|}{ Physical violence ${ }^{a}$ only } & \multicolumn{2}{|c|}{ Sexual violence ${ }^{b}$ only } & \multicolumn{2}{|c|}{$\begin{array}{c}\text { Sexual or physical } \\
\text { violence }\end{array}$} & \multicolumn{2}{|c|}{$\begin{array}{c}\text { Sexual and physical } \\
\text { violence }\end{array}$} \\
\hline & $\begin{array}{l}\text { Ages } \\
15-19\end{array}$ & $\begin{array}{l}\text { Ages } \\
20-24\end{array}$ & $\begin{array}{c}\text { Ages } \\
15-19\end{array}$ & $\begin{array}{l}\text { Ages } \\
20-24\end{array}$ & $\begin{array}{l}\text { Ages } \\
15-19\end{array}$ & $\begin{array}{c}\text { Ages } \\
20-24\end{array}$ & $\begin{array}{l}\text { Ages } \\
15-19\end{array}$ & $\begin{array}{l}\text { Ages } \\
20-24\end{array}$ \\
\hline Mainland & 61.9 & 39.4 & 2.3 & 7.6 & 81.0 & 69.4 & 16.0 & 22.2 \\
\hline Zanzibar & 60.2 & 53.3 & 2.6 & 2.4 & 72.6 & 74.5 & 9.3 & 18.3 \\
\hline National & 61.9 & 39.8 & 2.3 & 7.5 & 80.8 & 69.5 & 15.8 & 22.1 \\
\hline
\end{tabular}

Note: Read the first column of data as "Percent of 15-19 year old males who have ever experienced physical violence but not sexual violence," using 2009 VACS.

a 'Physical violence' includes violence by current/former spouse, or physical violence from someone other than spouse since the age of 15. ' 'Sexual violence' includes sexual violence by husband/partner; ever forced to perform unwanted sexual acts by anyone; ever forced to have sex by anyone other than current partner in past 12 months; and first sex was forced by anyone. 


\subsection{Perpetrators of Sexual Violence}

Tables 29A and 29B1-2 show the types of persons who are reported to have committed sexual violence against young people. The TDHS questioned ever-married women about spousal violence, and additionally asked all women to list anyone else who had committed violence. The 2009 VACS included more detailed questioning about specific types of perpetrator (i.e., current/former lover; parent or adult relative; people with authority, including police, teacher, religious leader or soldier). Across both the TDHS and VACS datasets, with increasing age, sexual violence is more likely to be perpetrated by a partner or spouse, rather than a relative or other person (e.g., authority figure, teacher, stranger).

2010 TDHS: Among 20-24 year old females who had experienced sexual violence, the majority (56\%) reported a spouse as the perpetrator, while at younger ages, such as ages $15-17$, only $10 \%$ of sexual violence reportedly was perpetrated by a spouse.

\begin{tabular}{|c|c|c|c|c|}
\hline \multicolumn{6}{|c|}{ Table 29A: Among Females Who Ever Experienced Sexual Violence, Percent Who Report } \\
Spouse as Perpetrator, by Age (DHS 2010) \\
\hline Region & Ages 15-17 & Ages 18-19 & Ages 15-19 & Ages 20-24 \\
\hline Mainland & 10.0 & 36.3 & 22.5 & 56.5 \\
\hline Zanzibar & $\star$ & $*$ & $*$ & 20.1 \\
\hline Urban & 11.4 & 16.2 & 13.3 & 43.3 \\
\hline Rural & 9.5 & 40.9 & 25.2 & 62.5 \\
\hline National & 10.0 & 36.0 & 22.4 & 55.9 \\
\hline
\end{tabular}

Note: Read the first column of data as "Percent of 15-17 year old females who have ever

experienced sexual violence who reported that spouse perpetrated the sexual violence," using 2010 DHS.

2009 VACS: Tables 29B1-2 focus on the perpetrators of sexual violence for each of the four types of sexual violence surveyed (see section 4.2). Females were most likely to report that someone other than their current or former boyfriend, romantic partner, spouse, or relative perpetrated the sexual violence. Specifically, 'other' perpetrators listed include neighbours, strangers and authority figures (the majority of whom were male teachers). Males ages 15-19 were most likely to report that a girlfriend, romantic partner or spouse perpetrated the violence, while males ages 20-24 most often reported another person was responsible for the violence. Across both genders and age groups, young people were least likely to report that a relative had perpetrated sexual violence.

\begin{tabular}{|c|c|c|c|c|c|c|}
\hline \multirow[b]{2}{*}{ Region } & \multicolumn{2}{|c|}{$\begin{array}{c}\text { Partner (current or } \\
\text { former) }\end{array}$} & \multicolumn{2}{|c|}{ Relative } & \multicolumn{2}{|c|}{ Otherb } \\
\hline & $\begin{array}{l}\text { Ages } \\
15-19\end{array}$ & $\begin{array}{c}\text { Ages } \\
20-24\end{array}$ & $\begin{array}{l}\text { Ages } \\
15-19\end{array}$ & $\begin{array}{c}\text { Ages } \\
20-24\end{array}$ & $\begin{array}{l}\text { Ages } \\
15-19\end{array}$ & $\begin{array}{c}\text { Ages } \\
20-24\end{array}$ \\
\hline Mainland & 18.3 & 25.7 & 4.3 & 7.0 & 29.0 & 37.4 \\
\hline Zanzibar & 6.0 & 12.4 & 3.6 & 4.0 & 5.2 & 25.5 \\
\hline National & 18.2 & 25.6 & 4.3 & 7.0 & 28.8 & 37.3 \\
\hline
\end{tabular}

Notes: Read the first column of data as "Percent of 15-19 year old females who ever experienced sexual violence who reported that their spouse, boyfriend or romantic partner perpetrated the sexual violence," using 2009 VACS. Figures in highlighted cells are based on 25-50 unweighted counts. a Percents do not sum to $100 \%$ because person is reporting on up to 8 incidents of sexual violence, each of which could have a different perpetrator. Also, not all respondents provided full information on perpetrators. ${ }^{b}$ Including teacher, religious leader, police, employer, or stranger. 


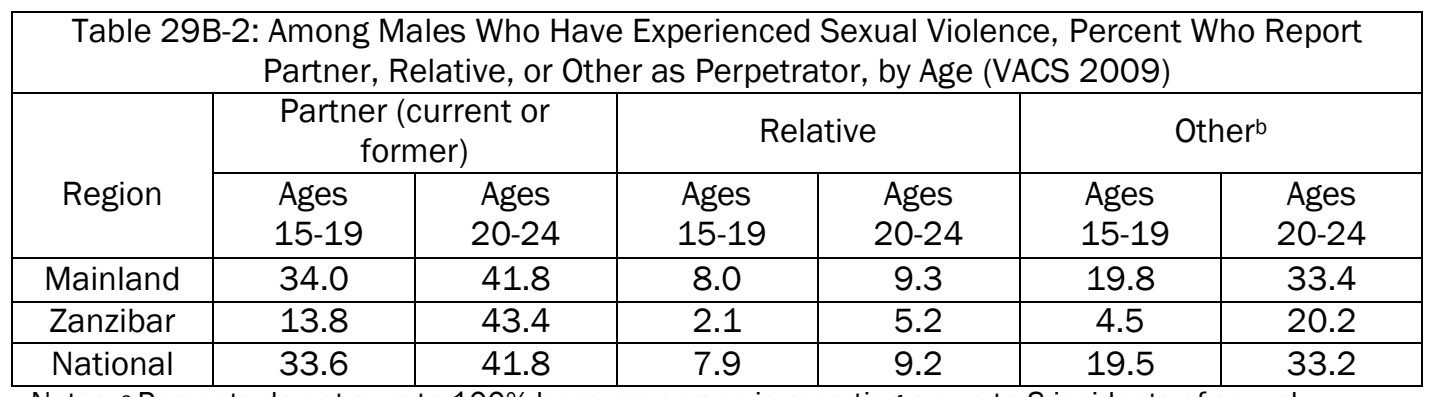

Notes: a Percents do not sum to $100 \%$ because person is reporting on up to 8 incidents of sexual violence, each of which could have a different perpetrator and not all respondents provided full information.

b Including teacher, religious leader, police, employer, or stranger.

\subsection{Perpetrators of Physical Violence}

2010 DHS: Table 30A shows data on the types of persons who were reported to commit physical violence against females. Similar to the findings on sexual violence, an increasing percent of females reported experiencing spousal violence with increasing age (4\% of females ages 15-17, relative to $22 \%$ of those ages $20-24$ ). This trend likely reflects the fact that a higher percent of girls are married by ages 20-24, and the main perpetrator of physical violence for married females is their spouse. For younger females (ages 15-19), relatives and 'other' persons are the primary perpetrators of physical violence. Among relatives, the primary perpetrators reported were mothers or a sibling (cited by 17\% of females ages 15-19 who had experienced physical violence, respectively), while the most cited 'other' perpetrators were teachers (cited by $29 \%$ of females ages 15-19 who had experienced physical violence).

\begin{tabular}{|c|c|c|c|c|c|}
\hline \multicolumn{6}{|c|}{$\begin{array}{c}\text { Table 30A: Among Females Who Ever Experienced Physical Violence, }{ }^{\text {a Percent }} \text { Who Report } \\
\text { Partner, Relative, or Other as Perpetrator, by Age (DHS 2010) }\end{array}$} \\
\hline Ages & Region & Spouse & $\begin{array}{l}\text { Boyfriend or } \\
\text { former partner }\end{array}$ & Relative & $\begin{array}{l}\text { Other } \\
\text { personb }\end{array}$ \\
\hline \multirow[t]{3}{*}{$15-17$} & Urban & 0.0 & 0.0 & 57.0 & 47.4 \\
\hline & Rural & 4.8 & 4.7 & 53.9 & 45.4 \\
\hline & National & 3.5 & 3.4 & 54.7 & 46 \\
\hline \multirow[t]{3}{*}{$18-19$} & Urban & 1.0 & 9.3 & 49.3 & 31.3 \\
\hline & Rural & 12.9 & 4.2 & 22.2 & 38.2 \\
\hline & National & 9.3 & 5.8 & 30.4 & 36.1 \\
\hline \multirow[t]{3}{*}{$15-19$} & Urban & 0.5 & 4.6 & 53.2 & 39.5 \\
\hline & Rural & 8.4 & 4.5 & 40 & 42.3 \\
\hline & National & 6.2 & 4.5 & 43.7 & 41.5 \\
\hline \multirow[t]{3}{*}{$20-24$} & Urban & 20.6 & 12.9 & 16.9 & 15.7 \\
\hline & Rural & 22.9 & 2.1 & 16.9 & 12.4 \\
\hline & National & 22.1 & 5.6 & 16.9 & 13.5 \\
\hline
\end{tabular}

Notes: Read the first column of data as "Among 15-17 year old females who have ever experienced physical violence, percent who reportde spouse as perpetrator," using 2010 DHS.

a 'Physical violence' includes violence by a current or former spouse, or physical violence from someone other than spouse since the age of 15.

b Includes teachers, police, employers or someone else.

Figures in highlighted cells are based on 25-50 unweighted counts. Percents do not sum to $100 \%$ as categories are not mutually exclusive and due to some missing data. 
2009 VACS: Tables 30B1-2 show that among 15-19 year olds reporting physical violence, about $80 \%$ reported that the perpetrator was a relative ( $81 \%$ of females; $79 \%$ of males) and $75 \%$ reported the perpetrator was someone other than an intimate partner or relative ( $75 \%$ of females; $79 \%$ of males). The 'other' person most often reported by young people was a teacher. In contrast to findings on sexual violence, a much lower proportion of young people reported that an intimate partner (e.g., spouse, romantic partner, or girlfriend/boyfriend) committed physical violence against them. However, with increasing age, the likelihood of reporting that an intimate partner committed physical violence increases. Specifically, $6 \%$ of females and $1 \%$ of males ages $15-17$ reported that a partner had committed physical violence, compared to $29 \%$ of females and $18 \%$ of males ages 20 24 (see Annex Tables 30B1-2).

\begin{tabular}{|c|c|c|c|c|c|c|}
\hline \multicolumn{7}{|c|}{$\begin{array}{c}\text { Table 30B-1: Among Females Who Ever Experienced Physical Violence, Percenta Who Report } \\
\text { Partner, Relative, or Other as Perpetrator, by Age (VACS 2009) }\end{array}$} \\
\hline \multirow[b]{2}{*}{ Region } & \multicolumn{2}{|c|}{ Partner (Current/former) } & \multicolumn{2}{|c|}{ Parent or adult relative } & \multicolumn{2}{|c|}{ Otherb $^{b}$} \\
\hline & $\begin{array}{l}\text { Ages } \\
15-19\end{array}$ & $\begin{array}{c}\text { Ages } \\
20-24\end{array}$ & $\begin{array}{l}\text { Ages } \\
15-19\end{array}$ & $\begin{array}{c}\text { Ages } \\
20-24\end{array}$ & $\begin{array}{l}\text { Ages } \\
15-19\end{array}$ & $\begin{array}{c}\text { Ages } \\
20-24\end{array}$ \\
\hline Mainland & 9.8 & 29.8 & 80.7 & 75.2 & 74.4 & 69.7 \\
\hline Zanzibar & 3.7 & 7.4 & 78.2 & 64.8 & 75.0 & 72.7 \\
\hline National & 9.7 & 29.3 & 80.6 & 75.0 & 74.5 & 69.8 \\
\hline
\end{tabular}

Notes: Read the first column of data as "Percent of 15-19 year old females who ever experienced physical violence who reported that their spouse, boyfriend or romantic partner perpetrated the violence," using 2009 VACS. a Percents do not sum to 100\% because person is reporting on up to 8 incidents of sexual violence, each of which could have a different perpetrator. Also, not all respondents provided full information. ${ }^{b}$ Includes teacher, religious leader, police, employer, or stranger.

\begin{tabular}{|c|c|c|c|c|c|c|}
\hline \multicolumn{7}{|c|}{$\begin{array}{c}\text { Table 30B-2: Among Males Who Have Experienced Physical Violence, Percent }{ }^{a} \text { Who Report } \\
\text { Partner, Relative, or Other sa Perpetrator, by Age (VACS 2009) }\end{array}$} \\
\hline \multirow[b]{2}{*}{ Region } & \multicolumn{2}{|c|}{ Partner (Current/former) } & \multicolumn{2}{|c|}{ Parent or adult relative } & \multicolumn{2}{|c|}{ Otherb } \\
\hline & $\begin{array}{l}\text { Ages } \\
15-19\end{array}$ & $\begin{array}{l}\text { Ages } \\
20-24\end{array}$ & $\begin{array}{l}\text { Ages } \\
15-19\end{array}$ & $\begin{array}{l}\text { Ages } \\
20-24\end{array}$ & $\begin{array}{l}\text { Ages } \\
15-19\end{array}$ & $\begin{array}{l}\text { Ages } \\
20-24\end{array}$ \\
\hline Mainland & 4.3 & 18.3 & 78.5 & 74.8 & 79.4 & 61.8 \\
\hline Zanzibar & 6.6 & 15.4 & 86.4 & 85.1 & 63.2 & 65.8 \\
\hline National & 4.4 & 18.2 & 78.7 & 75.2 & 79.0 & 61.9 \\
\hline
\end{tabular}

Read the first column of data as "Percent of 15-19 year old males who ever experienced physical violence who reported that their spouse, girlfriend or romantic partner perpetrated the violence," using 2009 VACS. a Percents do not sum to $100 \%$ because person is reporting on up to 8 incidents of sexual violence, each of which could have a different perpetrator. Also, not all respondents provided full information. ${ }^{b}$ Including teacher, religious leader, police, employer, or stranger.

\subsection{Violence during Pregnancy}

2010 TDHS: The 2010 TDHS asked women who have ever been pregnant if anyone "hit, slapped, kicked, or did anything else to hurt you physically while you were pregnant?" Table 31A shows that 9\% of both 15-19 and 20-24 year old females experienced physical violence during pregnancy. The likelihood of having experienced violence during pregnancy is approximately equivalent across ages 15-17 to 20-24 years. Analyses of differences by regional variation are limited by small sample size. 


\begin{tabular}{|c|c|c|c|c|}
\hline \multicolumn{5}{|c|}{ Table 31A: Percent of Ever Pregnant Females Who Experienced Physical Violence } \\
During Pregnancy, by Age (DHS 2010) \\
\hline \multirow{2}{*}{ Region } & $\begin{array}{c}\text { Ages } \\
15-17\end{array}$ & $\begin{array}{c}\text { Ages } \\
18-19\end{array}$ & $\begin{array}{c}\text { Ages } \\
15-19\end{array}$ & $\begin{array}{c}\text { Ages } \\
20-24\end{array}$ \\
\hline Mainland & 8.9 & 9.5 & 9.3 & 8.9 \\
\hline Zanzibar & $\star$ & 20.8 & 18.3 & 7.1 \\
\hline Urban & $*$ & 10.4 & 7.4 & 10.0 \\
\hline Rural & 10.5 & 9.4 & 9.8 & 8.4 \\
\hline National & 8.9 & 9.6 & 9.4 & 8.8 \\
\hline
\end{tabular}

Notes: Read the first column of data as "Percent of 15-17 year old ever pregnant females who have ever experienced physical violence during pregnancy," using 2010 DHS.

Figures in highlighted cells are based on 25-50 unweighted cases; highlighted figures marked with an asterisk are based on less than 25 unweighted cases.

2009 VACS: The VACS also asked females about experiences of violence and pregnancy, but the question differed from the one used in the TDHS. Specifically, females were asked, "Did you ever get pregnant as a result of forced sex?" Table 31B shows that $5 \%$ of females ages $15-19$ and $8 \%$ ages 20-24 reported a pregnancy which resulted from forced sex. With increasing age, a higher percent of females reported this (4\% of those ages 15-17, compared to $8 \%$ of those ages 20-24) (see Annex Table 31B).

Females on the Mainland are more likely than those in Zanzibar to report pregnancy from forced sex. Also of note is that approximately $90 \%$ of females responded that they "Did Not Know" if they ever became pregnant as the result of forced sex.

\begin{tabular}{|l|c|c|c|c|c|c|}
\hline \multicolumn{2}{|c|}{ Table 31B: Percent of Females Whose Pregnancy Ever Resulted from Forced Sex, by } \\
Age (VACS 2009) \\
\hline \multirow{3}{*}{ Region } & \multicolumn{2}{|c|}{ No } & \multicolumn{2}{c|}{ Yes } & \multicolumn{2}{c|}{ Don't Know } \\
\cline { 2 - 7 } & Ages & Ages & Ages & Ages & Ages & Ages \\
& $15-19$ & $20-24$ & $15-19$ & $20-24$ & $15-19$ & $20-24$ \\
\hline Mainland & 2.6 & 3.4 & 5.5 & 8.5 & 91.9 & 88.0 \\
\hline Zanzibar & 0.7 & 0.5 & 1.1 & 1.1 & 98.2 & 98.5 \\
\hline National & 2.6 & 3.4 & 5.4 & 8.3 & 92.1 & 88.3 \\
\hline
\end{tabular}

Note: Read the first column of data as "Percent of 15-19 year old females who did not become pregnant as a result of coerced or forced sex," using 2009 VACS.

\subsection{Orphan Status and Exposure to Violence}

The relationship between orphan status and exposure to violence was examined in both the TDHS and the VACS, because adolescents living without one or both parents may be at higher risk of violence.

2010 TDHS: Of females ages 15-17 whose mother and/or father had died, 6\% report having experienced sexual violence, compared to $12 \%$ of those who have both parents living (Table 32). 


\begin{tabular}{|c|c|c|c|}
\hline \multicolumn{4}{|c|}{ Table 32: Percent of Females 15-17 Who Ever Experienced Sexual Violence, } \\
by Orphan Status (DHS 2010)
\end{tabular}

Notes: Read the first column of data as "Percent of 15-17 year old females whose mothre and/or father had died who ever experienced sexual violence," using 2010 DHS; Figures in highlighted cells are based on 25-50 unweighted cases; highlighted figures marked with an asterisk are based on less than 25 unweighted cases.

2009 VACS: The prevalence of childhood emotional and sexual violence was somewhat higher for females ages 13-24 whose mother and/or father had died, compared to those who had not lost a parent (36\% versus $25 \%$ ). The prevalence of childhood emotional violence among males who lost their mother before the age of 18 was higher for the males. There was no observed correlation between physical violence and orphan status.

As with other violence indicators, the TDHS and VACS results are not directly comparable because of differences in the age difference of respondents, survey sampling, and the wording of the questions. 


\section{HIV/AIDS: KNOWLEDGE AND PREVALENCE}

This chapter presents data on HIV/AIDS knowledge, attitudes, related risks, and prevention behaviours. The chapter also details findings on HIV prevalence among young people according to the 2011-12 THMIS. These results can be used to target the most at-risk young people in need of prevention and treatment services.

\subsection{Knowledge of HIV Prevention Methods}

Knowledge of key sexual risk reduction methods, such as condom use and limiting partner number, is critical in preventing HIV infection (Mavedzenge et al. 2011). Tables 33A1-2 and 33B1-2 provide information on young people's knowledge of those behaviours, according to theTDHS and THMIS, respectively.

The majority of adolescents ages 15-19 have knowledge of both prevention methods (64\% of females and $60 \%$ of males in the TDHS; $53 \%$ of females and $61 \%$ of males in the THMIS). The surveys found higher levels of knowledge among respondents ages $20-24$ (73\% of females and $74 \%$ of males in the TDHS; $66 \%$ of females and $73 \%$ of males in the THMIS). Approximately threequarters of young people have knowledge of at least one HIV/AIDS prevention method across gender, age groups, and surveys. A higher percent know that HIV risk is reduced by limiting sexual intercourse to one uninfected partner who has no other partners, than know that using a condom reduces the risk of infection.

Other observed patterns in the two datasets are that more young people in Mainland areas than in Zanzibar have knowledge of both prevention methods. Similarly, urban females are likely to have higher knowledge of both prevention methods than rural females. This pattern is also observed for males ages 15-19 and 20-24 surveyed in the 2011-12 THMIS, but only among males ages 15-19 in the 2010 TDHS.

2010 TDHS: As shown in Tables 33A1-2, 7 in 10 respondents ages 15-19 (71\% of females and 69\% of males) know that using a condom during sexual intercourse can reduce the chance of acquiring HIV. Eight in 10 of same-aged respondents know that limiting sexual intercourse to one uninfected partner who has no other sexual partners can reduce the risk of infection. More than half of respondents ages $15-19$ have knowledge of both of these methods ( $64 \%$ of females and $60 \%$ of males). A higher percent of youth ages 20-24 relative to those ages 15-19 have knowledge of prevention methods.

There are notable differences in prevention knowledge by geographic area. In general, a greater proportion of youth in Mainland than in Zanzibar are aware of HIV prevention methods; HIV prevention knowledge was particularly low among males in Zanzibar. Prevention knowledge is higher in urban areas relative to rural areas for adolescents ages 15-19, and for females ages 20-24. There is also notable regional variation among females (see Annex Tables 33A1-2). For example, knowledge of both methods among females ages 15-19 is lowest in Kaskazini Unguja (44\%) while highest in Dodoma (83\%) and Pwani (93\%). Among males analysis of regional variation is limited by small sample sizes. 


\begin{tabular}{|c|c|c|c|c|c|c|}
\hline \multirow{2}{*}{ Table 33A-1: HIV Prevention Knowledge among Females Ages 15-24, Percent (DHS 2010) } \\
\hline \multirow{2}{*}{ Region } & \multicolumn{2}{|c|}{$\begin{array}{c}\text { Know that using a condom } \\
\text { can reduce risk of HIVa }\end{array}$} & $\begin{array}{c}\text { Know that having one } \\
\text { partner and no others can } \\
\text { reduce risk of HIV }\end{array}$ & \multicolumn{3}{|c|}{$\begin{array}{c}\text { Knowledge of both } \\
\text { prevention methods }\end{array}$} \\
\cline { 2 - 7 } & Ages 15-19 & Ages 20-24 & Ages 15-19 & Ages 20-24 & Ages 15-19 & Ages 20-24 \\
\hline Mainland & 71.7 & 78.3 & 82.3 & 89.3 & 64.2 & 73.5 \\
\hline Zanzibar & 59.7 & 63.3 & 85.6 & 91.9 & 55.1 & 60.8 \\
\hline Urban & 73.5 & 80.2 & 89.6 & 94.8 & 68.0 & 78.0 \\
\hline Rural & 70.2 & 76.6 & 79.4 & 86.7 & 62.1 & 70.7 \\
\hline National & 71.2 & 77.8 & 82.5 & 89.4 & 63.8 & 73.1 \\
\hline
\end{tabular}

Notes: Read the first column of data as "Percent of 15-19 year old females who know that people can reduce the risk of getting the AIDS virus by using condoms every time they have sexual intercourse," using 2010 DHS. a Using condoms every time they have sexual intercourse; b partner who has no other partners.

\begin{tabular}{|c|c|c|c|c|c|c|}
\hline \multirow{2}{*}{ Table 33 A-2: HIV Prevention Knowledge among Males Ages 15-24, Percent (DHS 2010) } \\
\hline \multirow{2}{*}{ Region } & $\begin{array}{c}\text { Know that using a condom } \\
\text { can reduce risk of HIVa }\end{array}$ & $\begin{array}{c}\text { Know that having one } \\
\text { partner and no others can } \\
\text { reduce risk of HIVb }\end{array}$ & \multicolumn{3}{c|}{$\begin{array}{c}\text { Knowledge of both } \\
\text { prevention methods }\end{array}$} \\
\cline { 2 - 7 } & Ages 15-19 & Ages 20-24 & Ages 15-19 & Ages 20-24 & Ages 15-19 & Ages 20-24 \\
\hline Mainland & 70.0 & 78.1 & 83.6 & 93.0 & 60.6 & 74.4 \\
\hline Zanzibar & 49.1 & 52.7 & 69.8 & 78.7 & 36.3 & 47.3 \\
\hline Urban & 76.6 & 75.0 & 89.0 & 95.3 & 70.3 & 72.9 \\
\hline Rural & 66.9 & 78.3 & 81.2 & 91.4 & 56.2 & 73.8 \\
\hline National & 69.3 & 77.3 & 83.1 & 92.6 & 59.7 & 73.5 \\
\hline
\end{tabular}

Notes: Read the first column of data as "Percent of 15-19 year old males who know that people can reduce the risk of getting the AIDS virus by using condoms every time they have sexual intercourse," using 2010 DHS. a Using condoms every time they have sexual intercourse; ${ }^{b}$ partner who has no other partners.

2011-12 THMIS: Similar to findings in the TDHS, Tables 33B1-2 show a reasonable level of prevention knowledge among youth related to condom use and limiting number of sexual partners. About 6 in 10 females (61\%) and 7 in 10 males (72\%) ages 15-19 are aware that using a condom during sexual intercourse can reduce one's chance of getting the AIDS virus. Slightly more youth ages 15-19, nearly 8 in 10, are aware that limiting number of sexual partners can reduce the chance of getting the virus ( $78 \%$ of females and $79 \%$ of males, respectively). Males have higher knowledge of both methods than females (61\% of males, $53 \%$ of females ages $15-19)$. Older youth (ages 20-24) have higher levels of knowledge when compared to those in middle adolescence (ages 15-19).

Prevention knowledge varies markedly by area of residence. Generally, youth in Mainland and urban areas have greater knowledge of both prevention methods relative to respondents in Zanzibar or rural areas. At the regional level, knowledge of both prevention methods is lowest among girls ages 15-19 in Tanga and Simiyu (29\% and 30\% respectively) and Mijini Magharibi and Kaskazini Pemba among males (34\% and 35\% respectively). Knowledge of both methods is high in Pwani (81\% of females ages 15-19) and Iringa (87\% of males ages 15-19) (see Annex Tables 33B1-2). 


\begin{tabular}{|c|c|c|c|c|c|c|}
\hline \multirow{2}{*}{ Table 33B-1: HIV Prevention Knowledge among Females Ages 15-24, Percent (THMIS 2011-2012) } \\
\hline \multirow{2}{*}{ Region } & \multicolumn{2}{|c|}{$\begin{array}{c}\text { Know that using a condom } \\
\text { can reduce risk of HIVa }\end{array}$} & $\begin{array}{c}\text { Know that having one } \\
\text { partner and no others can } \\
\text { reduce risk of HIVb }\end{array}$ & \multicolumn{3}{|c|}{$\begin{array}{c}\text { Knowledge of both } \\
\text { prevention methods }\end{array}$} \\
\cline { 2 - 7 } & Ages 15-19 & Ages 20-24 & Ages 15-19 & Ages 20-24 & Ages 15-19 & Ages 20-24 \\
\hline Mainland & 61.4 & 73.6 & 77.6 & 84.9 & 53.4 & 66.6 \\
\hline Zanzibar & 42.1 & 56.3 & 83.8 & 93.4 & 40.2 & 54.8 \\
\hline Urban & 70.3 & 78.8 & 87.8 & 93.7 & 65.6 & 76.3 \\
\hline Rural & 57.0 & 70.7 & 74.2 & 82.1 & 48.3 & 62.4 \\
\hline National & 60.6 & 72.9 & 77.9 & 85.3 & 52.9 & 66.1 \\
\hline
\end{tabular}

Notes: Read the first column of data as "Percent of 15-19 year old females who know that people can reduce the risk of getting the AIDS virus by using condoms every time they have sexual intercourse," using 2011-12 THMIS. a Using condoms every time they have sexual intercourse; ${ }^{b}$ partner who has no other partners.

\begin{tabular}{|c|c|c|c|c|c|c|}
\hline \multirow{2}{*}{ Table 33B-2: HIV Prevention Knowledge among Males Ages 15-24, Percent (THMIS 2011-2012) } \\
\hline \multirow{2}{*}{ Region } & \multicolumn{2}{|c|}{$\begin{array}{c}\text { Know that using a condom } \\
\text { can reduce risk of HIVa }\end{array}$} & $\begin{array}{c}\text { Know that having one } \\
\text { partner and no others can } \\
\text { reduce risk of HIV }\end{array}$ & \multicolumn{3}{c|}{$\begin{array}{c}\text { Knowledge of both } \\
\text { prevention methods }\end{array}$} \\
\cline { 2 - 8 } & Ages 15-19 & Ages 20-24 & Ages 15-19 & Ages 20-24 & Ages 15-19 & Ages 20-24 \\
\hline Mainland & 73.4 & 80.0 & 78.4 & 88.3 & 61.5 & 73.9 \\
\hline Zanzibar & 46.6 & 43.1 & 79.1 & 82.2 & 39.0 & 39.3 \\
\hline Urban & 71.0 & 81.5 & 86.7 & 92.8 & 64.4 & 77.3 \\
\hline Rural & 72.8 & 77.4 & 75.9 & 86.0 & 59.5 & 70.6 \\
\hline National & 72.4 & 78.6 & 78.5 & 88.0 & 60.7 & 72.6 \\
\hline
\end{tabular}

Notes: Read the first column of data as "Percent of 15-19 year old males who know that people can reduce the risk of getting the AIDS virus by using condoms every time they have sexual intercourse," using 2011-12 THMIS. a Using condoms every time they have sexual intercourse; b partner who has no other partners.

\subsection{Comprehensive HIV Knowledge}

Both the TDHS and the THMIS asked youth about common misconceptions regarding HIV/AIDS. Comprehensive HIV knowledge is defined as: knowledge that a healthy-looking person can have the AIDS virus; rejection of two of the most common local misconceptions about HIV/AIDS transmission and prevention; and knowledge that consistent condom use during sexual intercourse and having just one uninfected faithful partner can reduce the risk of contracting HIV/AIDS. According to the 2010 TDHS, the two most common misconceptions regarding HIV/AIDS are that AIDS can be transmitted by mosquito bites or by supernatural means. Tables 34A1-2 and 34B1-2 present data on comprehensive HIV knowledge among youth ages 15-24, respectively.

Taken together, data from both surveys indicate that there is high overall rejection of common misconceptions about HIV/AIDS transmission among youth. Comprehensive HIV knowledge is low, however. On the whole, less than half of youth surveyed have comprehensive knowledge in both the TDHS and the THMIS.

2010 TDHS: The large majority of youth surveyed in the 2010 TDHS knew that a healthy person can have HIV, and that AIDS cannot be transmitted by mosquito bites or supernatural means (greater than 8 in 10 respondents aged 15-19 and 20-24, respectively). Approximately half of females (46\% of females ages $15-19$, and $50 \%$ of females ages $20-24$ ) and slightly less than half of males (41\% of boys ages $15-19$, and $45 \%$ of those ages $20-24$ ) have comprehensive HIV knowledge, as defined above.

Age differences in rejection of AIDS misconceptions are minimal, although a slightly (4\%) greater percent of older respondents (ages 20-24) have comprehensive knowledge than younger respondents (ages 15-19). 15-19 year old females in Zanzibar are less knowledgeable about AIDS than those in Mainland areas (30\% and $47 \%$, respectively). The same pattern was true for $15-19$ year old males (27\% and $41 \%$ in Zanzibar and Mainland areas, respectively). Respondents in rural 
compared to urban areas also have lower levels of comprehensive knowledge. Comprehensive knowledge also varies widely at the regional level. Among females ages 15-19, comprehensive knowledge ranged from 21\% and 22\% in Mwanza and Kaskazini Unguja, respectively, to 65\% in Dodoma. Analysis of regional variation among males is limited by small sample size (see Annex Tables 34A1-2).

\begin{tabular}{|c|c|c|c|c|c|c|c|c|}
\hline \multirow[t]{2}{*}{ Region } & \multicolumn{2}{|c|}{$\begin{array}{c}\text { A healthy-looking } \\
\text { person can have the } \\
\text { AIDS virus }\end{array}$} & \multicolumn{2}{|c|}{$\begin{array}{l}\text { AIDS cannot be } \\
\text { transmitted by } \\
\text { mosquito bites }\end{array}$} & \multicolumn{2}{|c|}{$\begin{array}{c}\text { AIDS cannot be } \\
\text { transmitted by } \\
\text { supernatural means }\end{array}$} & \multicolumn{2}{|c|}{$\begin{array}{c}\text { Percent with a } \\
\text { comprehensive } \\
\text { knowledge about } \\
\text { HIV/AIDS }\end{array}$} \\
\hline & $\begin{array}{c}\text { Ages } \\
15-19\end{array}$ & $\begin{array}{l}\text { Ages } \\
20-24\end{array}$ & $\begin{array}{l}\text { Ages } \\
15-19\end{array}$ & $\begin{array}{c}\text { Ages } \\
20-24\end{array}$ & $\begin{array}{c}\text { Ages } \\
15-19\end{array}$ & $\begin{array}{l}\text { Ages } \\
20-24\end{array}$ & $\begin{array}{c}\text { Ages } \\
15-19\end{array}$ & $\begin{array}{c}\text { Ages } \\
20-24\end{array}$ \\
\hline Mainland & 81.8 & 85.2 & 85.1 & 81.6 & 87.8 & 84.2 & 46.9 & 50.8 \\
\hline Zanzibar & 82.4 & 89.7 & 84.6 & 80.6 & 74.0 & 75.0 & 30.2 & 38.6 \\
\hline Urban & 88.2 & 92.2 & 79.4 & 85.3 & 90.6 & 85.1 & 53.5 & 56.0 \\
\hline Rural & 79.1 & 82.0 & 90.2 & 79.6 & 85.9 & 83.3 & 43.3 & 47.7 \\
\hline National & 81.8 & 85.4 & 85.1 & 81.5 & 87.3 & 83.9 & 46.3 & 50.4 \\
\hline
\end{tabular}

Notes: Read the first column of data as "Percent of 15-19 year old females who know that a healthy-looking person can have the AIDS virus," using 2010 TDHS.

\begin{tabular}{|c|c|c|c|c|c|c|c|c|}
\hline \multirow[t]{2}{*}{ Region } & \multicolumn{2}{|c|}{$\begin{array}{c}\text { A healthy-looking } \\
\text { person can have the } \\
\text { AIDS virus }\end{array}$} & \multicolumn{2}{|c|}{$\begin{array}{l}\text { AIDS cannot be } \\
\text { transmitted by } \\
\text { mosquito bites }\end{array}$} & \multicolumn{2}{|c|}{$\begin{array}{c}\text { AIDS cannot be } \\
\text { transmitted by } \\
\text { supernatural means }\end{array}$} & \multicolumn{2}{|c|}{$\begin{array}{c}\text { Percent with a } \\
\text { comprehensive } \\
\text { knowledge about } \\
\text { HIV/AIDS }\end{array}$} \\
\hline & $\begin{array}{l}\text { Ages } \\
15-19\end{array}$ & $\begin{array}{c}\text { Ages } \\
20-24\end{array}$ & $\begin{array}{c}\text { Ages } \\
15-19\end{array}$ & $\begin{array}{l}\text { Ages } \\
20-24\end{array}$ & $\begin{array}{l}\text { Ages } \\
15-19\end{array}$ & $\begin{array}{l}\text { Ages } \\
20-24\end{array}$ & $\begin{array}{c}\text { Ages } \\
15-19\end{array}$ & $\begin{array}{l}\text { Ages } \\
20-24\end{array}$ \\
\hline Mainland & 79.9 & 88.9 & 77.3 & 76.1 & 89.6 & 89.4 & 41.4 & 45.8 \\
\hline Zanzibar & 83.7 & 93.0 & 84.5 & 87.6 & 86.7 & 86.6 & 26.6 & 34.9 \\
\hline Urban & 89.2 & 93.8 & 90.6 & 80.5 & 92.0 & 96.8 & 60.1 & 52.8 \\
\hline Rural & 77.0 & 87.0 & 73.1 & 74.8 & 88.6 & 86.2 & 34.5 & 42.3 \\
\hline National & 80.0 & 89.0 & 77.5 & 76.5 & 89.5 & 89.3 & 40.9 & 45.4 \\
\hline
\end{tabular}

Notes: Read the first column of data as "Percent of 15-19 year old males who know that a healthy-looking person can have the AIDS virus," using 2010 TDHS.

2011-12 THMIS: Tables 34B1-2 present findings on comprehensive knowledge of AIDS according to the THMIS. Similar to the 2010 TDHS, the vast majority of youth reject common myths about HIV/AIDS. 8 in 10 15-19 year old respondents know a healthy-looking person can have AIDS (76\% of females and $80 \%$ of males) and that AIDS cannot be transmitted by mosquito bites ( $84 \%$ of females and $83 \%$ of males), while 9 in 10 (89\% of females and $88 \%$ of males) know that AIDS cannot be transmitted by supernatural means. Less than half of respondents ages 15-19 (37\% of females and $42 \%$ of males) have comprehensive knowledge of AIDS. A higher percent of 20-24 year old respondents have comprehensive knowledge (44\% of females and $53 \%$ of males ages $20-24$ ). Similarly, a higher percent of older respondents are aware that a healthy-looking person can have AIDS ( $80 \%$ of females, and $87 \%$ of males ages $20-24$ ), relative to younger respondents. Knowledge that AIDS cannot be transmitted by mosquito bites or though supernatural means is approximately equivalent among age groups.

Unlike findings observed in the 2010 TDHS, respondents in Mainland areas do not have consistently higher levels of comprehensive AIDS knowledge than those in Zanzibar. Specifically, Mainland males, but not females, have higher levels of knowledge relative to those in Zanzibar. However, 
similar to the 2010 TDHS, 15-19 year old urban residents have greater comprehensive HIV/AIDS knowledge (51\% and $32 \%$ of females, and $48 \%$ and $40 \%$ of males, respectively). Regional data comprehensive AIDS knowledge is presented in Annex Tables 34B1-2. Only 13\% of females ages 1519 in Simiyu and 16\% of those in Kaskazini Unguja have comprehensive knowledge, while the rate is $69 \%$ among females in Pwani. Regional variation among 15-19 year old boys is also high, ranging from $22 \%$ of males in Kaskazini Pemba to $69 \%$ in Iringa.

\begin{tabular}{|c|c|c|c|c|c|c|c|c|}
\hline \multicolumn{9}{|c|}{ 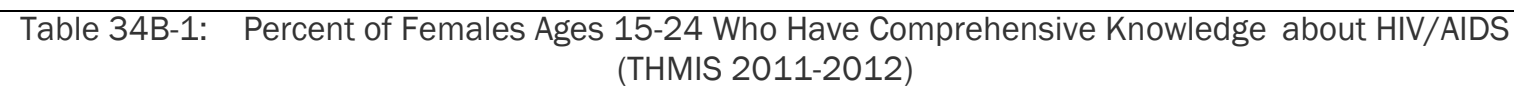 } \\
\hline \multirow[t]{2}{*}{ Region } & \multicolumn{2}{|c|}{$\begin{array}{l}\text { A healthy-looking } \\
\text { person can have the } \\
\text { AIDS virus }\end{array}$} & \multicolumn{2}{|c|}{$\begin{array}{l}\text { AIDS cannot be } \\
\text { transmitted by } \\
\text { mosquito bites }\end{array}$} & \multicolumn{2}{|c|}{$\begin{array}{l}\text { AIDS cannot be } \\
\text { transmitted by } \\
\text { supernatural means }\end{array}$} & \multicolumn{2}{|c|}{$\begin{array}{c}\text { Percent with a } \\
\text { comprehensive } \\
\text { knowledge about } \\
\text { HIV/AIDS }\end{array}$} \\
\hline & $\begin{array}{c}\text { Ages } \\
15-19\end{array}$ & $\begin{array}{c}\text { Ages } \\
20-24\end{array}$ & $\begin{array}{c}\text { Ages } \\
15-19\end{array}$ & $\begin{array}{c}\text { Ages } \\
20-24\end{array}$ & $\begin{array}{c}\text { Ages } \\
15-19\end{array}$ & $\begin{array}{c}\text { Ages } \\
20-24\end{array}$ & $\begin{array}{c}\text { Ages } \\
15-19\end{array}$ & $\begin{array}{c}\text { Ages } \\
20-24\end{array}$ \\
\hline Mainland & 75.2 & 87.2 & 84.3 & 82.2 & 90.0 & 87.6 & 37.2 & 44.3 \\
\hline Zanzibar & 93.6 & 76.4 & 87.7 & 86.3 & 72.3 & 74.1 & 27.1 & 42.1 \\
\hline Urban & 81.5 & 87.2 & 90.1 & 87.3 & 93.2 & 88.4 & 50.5 & 53.6 \\
\hline Rural & 73.8 & 76.4 & 82.3 & 80.6 & 87.8 & 86.5 & 31.8 & 40.7 \\
\hline National & 75.9 & 79.3 & 84.4 & 82.4 & 89.3 & 87.0 & 36.8 & 44.2 \\
\hline
\end{tabular}

\begin{tabular}{|c|c|c|c|c|c|c|c|c|}
\hline \multicolumn{2}{|c|}{ Table 34B-2: Percent of Males Ages 15-24 Who Have Comprehensive Knowledge about HIV/AIDS } \\
(THMIS 2011-2012) \\
\hline \multirow{3}{*}{ Region } & $\begin{array}{c}\text { A healthy-looking } \\
\text { person can have the } \\
\text { AIDS virus }\end{array}$ & \multicolumn{2}{|c|}{$\begin{array}{c}\text { AIDS cannot be } \\
\text { transmitted by } \\
\text { mosquito bites }\end{array}$} & $\begin{array}{c}\text { AIDS cannot be } \\
\text { transmitted by } \\
\text { supernatural means }\end{array}$ & $\begin{array}{c}\text { Percent with a } \\
\text { comprehensive } \\
\text { knowledge about } \\
\text { HIV/AIDS }\end{array}$ \\
\cline { 2 - 10 } & $\begin{array}{c}\text { Ages } \\
15-19\end{array}$ & $\begin{array}{c}\text { Ages } \\
20-24\end{array}$ & $\begin{array}{c}\text { Ages } \\
15-19\end{array}$ & $\begin{array}{c}\text { Ages } \\
20-24\end{array}$ & $\begin{array}{c}\text { Ages } \\
15-19\end{array}$ & $\begin{array}{c}\text { Ages } \\
20-24\end{array}$ & $\begin{array}{c}\text { Ages } \\
15-19\end{array}$ & $\begin{array}{c}\text { Ages } \\
20-24\end{array}$ \\
\hline Mainland & 79.6 & 86.3 & 82.6 & 82.7 & 88.3 & 90.6 & 42.4 & 53.7 \\
\hline Zanzibar & 87.6 & 93.6 & 82.9 & 88.4 & 82.9 & 92.4 & 27.6 & 35.0 \\
\hline Urban & 90.8 & 94.1 & 85.8 & 91.5 & 91.6 & 91.5 & 48.4 & 64.5 \\
\hline Rural & 76.5 & 83.4 & 81.7 & 79.2 & 87.1 & 90.3 & 39.9 & 48.1 \\
\hline National & 79.9 & 86.6 & 82.6 & 82.9 & 88.1 & 90.6 & 41.9 & 53.0 \\
\hline
\end{tabular}

\subsection{Knowledge of Prevention of Mother-to-Child HIV Transmission (PMTCT)}

Knowledge of methods to prevent HIV transmission from mother to child is critical for effective HIV prevention during pregnancy, delivery and breastfeeding. To assess PMTCT knowledge, respondents in both theTDHS and THMIS were asked: (1) if the virus that causes AIDS can be transmitted from mother to child through breastfeeding; and (2) whether a mother with HIV can reduce the risk of transmission to her infant by taking certain drugs during pregnancy. Tables 35A1-2 and 35B1-2 present data on PMTCT knowledge among youth.

2010 TDHS: Tables 35A1-2 show that $61 \%$ of females and 51\% of males ages 15-19 are aware that HIV can be transmitted by breastfeeding and that the risk of mother-to-child transmission can be reduced by taking special drugs during pregnancy. Older respondents have higher knowledge of both aspects of PMTCT prevention (78\% of females and $61 \%$ of males ages $20-24)$. Among both sexes and across age groups, knowledge that HIV can be transmitted by breastfeeding is higher than knowledge that HIV-positive mothers can take special drugs to reduce the risk of mother-tochild transmission during pregnancy.

In contrast to observed patterns of comprehensive and preventative HIV knowledge, awareness of both aspects of PMTCT is higher among respondents in Zanzibar relative to Mainland areas. For 
example, $72 \%$ of Zanzibar females ages $15-19$ are aware of both aspects of PMTCT relative to $60 \%$ of those in Mainland areas. Similarly, 62\% of Zanzibar males ages 15-19 are aware of both aspects of PMTCT relative to 51\% in Mainland areas. 15-19 year old urban respondents also have higher knowledge of both aspects of PMTCT than those in rural areas $(73 \%$ and $56 \%$ of females, and $65 \%$ and $47 \%$ of males, respectively). See Annex Tables 35A1-2 for additional data related to respondent age group and region.

\begin{tabular}{|c|c|c|c|c|c|c|}
\hline \multicolumn{2}{|c|}{ Table 35A-1: Percent of Females Ages 15-24 Who Have Knowledge of Prevention of Mother-to- } \\
Child Transmission of HIV (DHS, 2010)
\end{tabular}
transmitted from mother to child by breastfeeding," using 2010 TDHS.

\begin{tabular}{|c|c|c|c|c|c|c|}
\hline \multicolumn{7}{|c|}{$\begin{array}{c}\text { Table 35A-2: Percent of Males Ages 15-24 Who Have Knowledge of Prevention of Mother-to-Child } \\
\text { Transmission of HIV (DHS, 2010) }\end{array}$} \\
\hline \multirow[t]{2}{*}{ Region } & \multicolumn{2}{|c|}{$\begin{array}{l}\text { HIV can be transmitted by } \\
\text { breastfeeding }\end{array}$} & \multicolumn{2}{|c|}{$\begin{array}{l}\text { Risk of MTCT can be } \\
\text { reduced by mother taking } \\
\text { special drugs during } \\
\text { pregnancy }\end{array}$} & \multicolumn{2}{|c|}{$\begin{array}{l}\text { HIV can be transmitted by } \\
\text { breastfeeding, and risk of } \\
\text { MTCT can be reduced by } \\
\text { special drugs in pregnancy }\end{array}$} \\
\hline & Ages 15-19 & Ages 20-24 & Ages 15-19 & Ages 20-24 & Ages 15-19 & Ages 20-24 \\
\hline Mainland & 77.0 & 85.1 & 66.6 & 69.6 & 50.8 & 60.6 \\
\hline Zanzibar & 77.0 & 92.2 & 78.1 & 86.3 & 62.0 & 79.8 \\
\hline Urban & 81.0 & 90.2 & 82.9 & 81.8 & 65.2 & 73.8 \\
\hline Rural & 75.7 & 83.4 & 61.1 & 64.9 & 46.5 & 55.9 \\
\hline National & 77.0 & 85.4 & 67.0 & 70.1 & 51.2 & 61.2 \\
\hline
\end{tabular}

Note: Read the first column of data as "Percent of 15-19 year old males who know that HIV can be transmitted from mother to child by breastfeeding," using 2010 TDHS.

2011-12 THMIS: Tables 35B1-2 show that 52\% of females and 46\% of males ages $15-19$ are aware that HIV can be transmitted by breastfeeding and that the risk of mother-to-child transmission can be reduced by taking special drugs during pregnancy. As seen in the 2010 TDHS, older respondents have higher knowledge of both aspects of PMTCT prevention (70\% of females and $56 \%$ of males ages 20-24). A higher percent of respondents know that HIV can be transmitted by breastfeeding than know that mother-to-child transmission can be prevented by the mother taking special drugs during pregnancy.

PMTCT knowledge varies by area of residence. As seen in the 2010 TDHS, Zanzibar respondents generally have higher knowledge than those in Mainland areas. Knowledge is also higher among youth in urban relative to rural areas. See Annex Tables 35B1-2 for additional data by respondent age group and region. 


\begin{tabular}{|c|c|c|c|c|c|c|}
\hline \multirow[t]{2}{*}{ Region } & \multicolumn{2}{|c|}{$\begin{array}{l}\text { HIV can be transmitted by } \\
\text { breastfeeding }\end{array}$} & \multicolumn{2}{|c|}{$\begin{array}{l}\text { Risk of MTCT can be } \\
\text { reduced by mother taking } \\
\text { special drugs during } \\
\text { pregnancy }\end{array}$} & \multicolumn{2}{|c|}{$\begin{array}{l}\text { HIV can be transmitted by } \\
\text { breastfeeding, and risk of } \\
\text { MTCT can be reduced by } \\
\text { mother taking special } \\
\text { drugs during pregnancy }\end{array}$} \\
\hline & $\begin{array}{c}\text { Ages } \\
15-19\end{array}$ & $\begin{array}{c}\text { Ages } \\
20-24\end{array}$ & $\begin{array}{c}\text { Ages } \\
15-19\end{array}$ & $\begin{array}{c}\text { Ages } \\
20-24\end{array}$ & $\begin{array}{c}\text { Ages } \\
15-19\end{array}$ & $\begin{array}{c}\text { Ages } \\
20-24\end{array}$ \\
\hline Mainland & 76.9 & 87.0 & 65.9 & 78.1 & 51.3 & 69.5 \\
\hline Zanzibar & 91.4 & 93.8 & 70.3 & 86.2 & 64.1 & 81.1 \\
\hline Urban & 84.2 & 92.8 & 77.5 & 88.4 & 65.3 & 83.5 \\
\hline Rural & 74.9 & 85.1 & 61.5 & 74.5 & 46.7 & 64.9 \\
\hline National & 77.4 & 87.2 & 66.1 & 78.5 & 51.8 & 70.0 \\
\hline
\end{tabular}

Note: Read the first column of data as "Percent of 15-19 year old females who know that HIV can be transmitted from mother to child by breastfeeding," using 2011-12 TDHS.

\begin{tabular}{|c|c|c|c|c|c|c|}
\hline \multicolumn{7}{|c|}{ Table 35B-2: } \\
\hline \multirow[t]{2}{*}{ Region } & \multicolumn{2}{|c|}{$\begin{array}{l}\text { HIV can be transmitted by } \\
\text { breastfeeding }\end{array}$} & \multicolumn{2}{|c|}{$\begin{array}{l}\text { Risk of MTCT can be } \\
\text { reduced by mother taking } \\
\text { special drugs during } \\
\text { pregnancy }\end{array}$} & \multicolumn{2}{|c|}{$\begin{array}{l}\text { HIV can be transmitted by } \\
\text { breastfeeding, and risk of } \\
\text { MTCT can be reduced by } \\
\text { mother taking special } \\
\text { drugs during pregnancy }\end{array}$} \\
\hline & $\begin{array}{c}\text { Ages } \\
15-19\end{array}$ & $\begin{array}{c}\text { Ages } \\
20-24\end{array}$ & $\begin{array}{c}\text { Ages } \\
15-19\end{array}$ & $\begin{array}{c}\text { Ages } \\
20-24\end{array}$ & $\begin{array}{c}\text { Ages } \\
15-19\end{array}$ & $\begin{array}{c}\text { Ages } \\
20-24\end{array}$ \\
\hline Mainland & 70.9 & 79.3 & 64.3 & 69.2 & 45.9 & 55.9 \\
\hline Zanzibar & 83.8 & 88.8 & 64.5 & 73.1 & 56.8 & 66.3 \\
\hline Urban & 75.9 & 88.1 & 71.3 & 72.5 & 54.7 & 64.6 \\
\hline Rural & 70.0 & 76.0 & 62.1 & 67.9 & 43.7 & 52.8 \\
\hline National & 71.4 & 79.6 & 64.3 & 69.4 & 46.3 & 56.3 \\
\hline
\end{tabular}

Note: Read the first column of data as "Percent of 15-19 year old males who know that HIV can be

transmitted from mother to child by breastfeeding," using 2011-12 THMIS.

\section{4. $\quad$ Attitudes Towards People Living with HIV/AIDS}

Stigma towards people living with HIV/AIDS can detrimentally affect people's willingness to undergo HIV testing and counseling, their initiation and continuation in care and treatment, and their adherence to antiretroviral therapy (Mills et al. 2006; Ostermann et al. 2011). To better understand stigma, tolerance, and acceptance towards people with HIV/AIDS, theTDHS and the THMIS asked respondents what their attitudes would be in particular scenarios. Specifically, the surveys asked respondents if: (1) they would care for a relative who was sick with AIDS in their own household; (2) they would buy fresh vegetables from a market vendor who had the AIDS virus; (3) they thought a female teacher who had the AIDS virus but was not sick should be allowed to continue teaching; and (4) they would want to keep a family member's HIV seropositivity status a secret.

Tables 36A1-2 and 36B1-2 present results of youth's attitudes towards people living with HIV/AIDS, as well as the percent of respondents who express acceptance towards people living with AIDS, as indicated by desirable responses to all four indicators.

2010 TDHS: Of all of the four indicators, youth were most likely to express willingness to care for a family member with the AIDS virus in their own home ( 9 in 10 of females and males ages 15-19 and 20-24, respectively). More than 7 in 10 youth would buy fresh vegetables from a shopkeeper who had the AIDS virus (70\% and $73 \%$ of females ages $15-19$ and $20-24$, respectively; $72 \%$ and $77 \%$ of 
males ages 15-19 and 20-24, respectively). More than half of females would want to keep it a secret that a family member was infected with the AIDS virus (58\% and $55 \%$ of females ages $15-19$ and 20-24, respectively). A lower percent of males would want to keep it secret that a family member was infected with AIDS (49\% and $41 \%$ of males ages $15-19$ and $20-24$, respectively). Less than one-third of females (30\% and $32 \%$ of those ages 15-19 and 20-24, respectively) and about $40 \%$ of males (36\% and $42 \%$ of males ages $15-19$ and $20-24$, respectively) gave desirable responses to all four indicators. Older respondents (ages 20-24) generally have more favorable attitudes towards persons living with HIV/AIDS than those ages 15-19.

Respondents ages 20-24 in Zanzibar show higher acceptance of all four tolerance indicators (42\% and $52 \%$ of females and males, respectively) relative to those in Mainland areas (31\% and $42 \%$ of females and males, respectively). Respondents in urban areas are about one and a half times as likely as those in rural areas favorably respond to all four indicators. Among females, the lowest rate of acceptance is in Manyara (15\% of females ages 15-19) and Dodoma (16\% of females ages 20 24 ), while the highest is in Kilimanjaro (49\% of females ages 15-19) and Mijini Magharibi (54\% of females ages 20-24). Analysis of regional variation among males is limited by small sample size (Annex Tables 36A1-2).

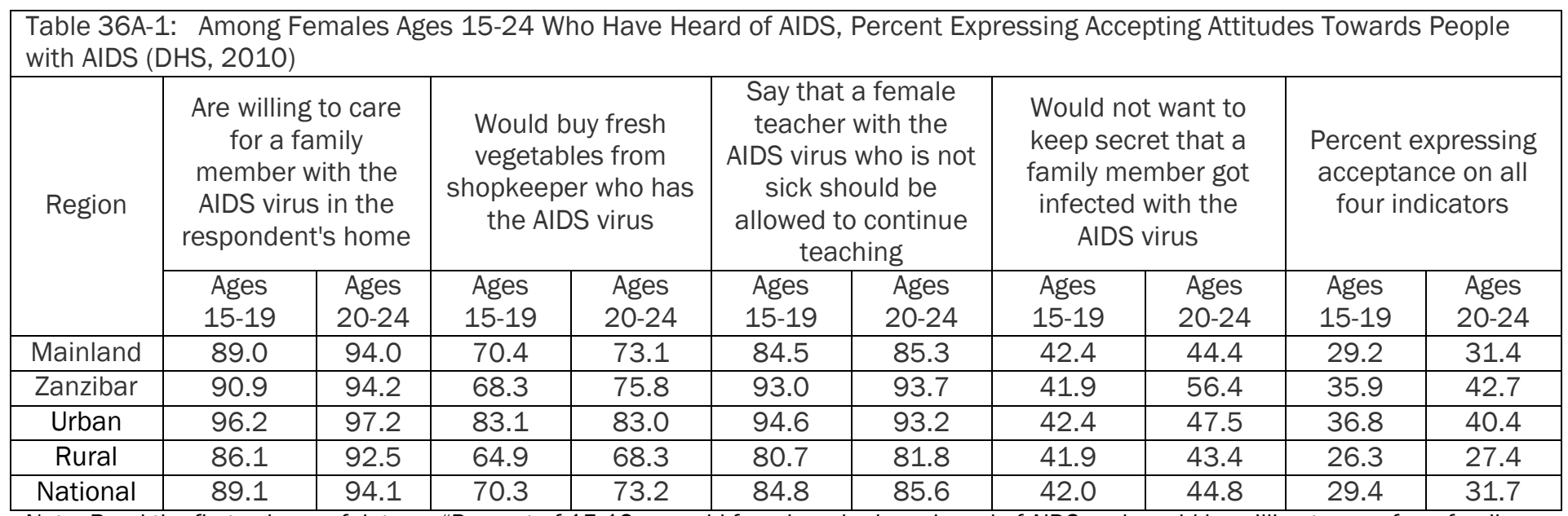

Note: Read the first column of data as "Percent of 15-19 year old females who have heard of AIDS and would be willing to care for a family member with the AIDS virus in the respondent's home," using 2010 TDHS.

\begin{tabular}{|c|c|c|c|c|c|c|c|c|c|c|}
\hline \multirow[t]{2}{*}{ Region } & \multicolumn{2}{|c|}{$\begin{array}{c}\text { Are willing to care for } \\
\text { a family member } \\
\text { with the AIDS virus in } \\
\text { the respondent's } \\
\text { home }\end{array}$} & \multicolumn{2}{|c|}{$\begin{array}{l}\text { Would buy fresh } \\
\text { vegetables from } \\
\text { shopkeeper who has } \\
\text { the AIDS virus }\end{array}$} & \multicolumn{2}{|c|}{$\begin{array}{l}\text { Say that a female } \\
\text { teacher with the } \\
\text { AIDS virus who is not } \\
\text { sick should be } \\
\text { allowed to continue } \\
\text { teaching }\end{array}$} & \multicolumn{2}{|c|}{$\begin{array}{l}\text { Would not want to } \\
\text { keep secret that a } \\
\text { family member got } \\
\text { infected with the } \\
\text { AIDS virus }\end{array}$} & \multicolumn{2}{|c|}{$\begin{array}{l}\text { Percent expressing } \\
\text { acceptance on all } \\
\text { four indicators }\end{array}$} \\
\hline & $\begin{array}{l}\text { Ages } \\
15-19\end{array}$ & $\begin{array}{c}\text { Ages } \\
20-24\end{array}$ & $\begin{array}{l}\text { Ages } \\
15-19\end{array}$ & $\begin{array}{c}\text { Ages } \\
20-24\end{array}$ & $\begin{array}{l}\text { Ages } \\
15-19\end{array}$ & $\begin{array}{c}\text { Ages } \\
20-24\end{array}$ & $\begin{array}{c}\text { Ages } \\
15-19\end{array}$ & $\begin{array}{c}\text { Ages } \\
20-24\end{array}$ & $\begin{array}{l}\text { Ages } \\
15-19\end{array}$ & $\begin{array}{c}\text { Ages } \\
20-24\end{array}$ \\
\hline Mainland & 91.8 & 96.6 & 71.3 & 76.3 & 79.4 & 83.5 & 50.9 & 59.1 & 35.7 & 41.8 \\
\hline Zanzibar & 90.9 & 96.2 & 75.1 & 83.9 & 92.3 & 90.7 & 60.4 & 64.2 & 44.4 & 52.0 \\
\hline Urban & 96.8 & 99.2 & 86.9 & 92.2 & 40.5 & 36.9 & 56.5 & 62 & 47.7 & 53.2 \\
\hline Rural & 90.1 & 95.5 & 66.3 & 69.9 & 48.7 & 39.8 & 49.5 & 58.1 & 32.1 & 37.4 \\
\hline National & 91.8 & 96.6 & 71.5 & 76.6 & 46.6 & 38.9 & 51.2 & 59.3 & 36.0 & 42.1 \\
\hline
\end{tabular}

Note: Read the first column of data as "Percent of 15-19 year old males who have heard of AIDS and would be willing to care for a family member with the AIDS virus in the respondent's home," using 2010 TDHS.

2011-12 THMIS: Similar to findings in the 2010 TDHS, of the four tolerance indicators surveyed among youth in the 2011-12 THMIS, respondents are most likely to express willingness to care for a 
family member with the AIDS virus in their own home (about 9 in 10 of females and males ages 1519 and 20-24, respectively). 6 in 10 respondents would buy fresh vegetables from a shopkeeper who had the AIDS virus (60\% and $65 \%$ of females ages $15-19$ and $20-24 ; 63 \%$ and $73 \%$ of males ages 15-19 and 20-24, respectively). More than half of females would want to keep it a secret that a family member was infected with the AIDS virus (62\% and 59\% of those ages 15-19 and 20-24, respectively), while about half of males would want to do so (49\% and $44 \%$ of those ages $15-19$ and 20-24, respectively). One-quarter or less of females (23\% and 26\% of those ages 15-19 and 20-24, respectively) and one-third or more of males (33\% and $40 \%$ of males ages $15-19$ and $20-24$, respectively) express acceptance in their responses to all four indicators. Older respondents (ages 20-24) generally have more favorable views towards persons living with HIV/AIDS than those ages 15-19.

As in the 2010 TDHS, females and males in Zanzibar show a higher acceptance of all four tolerance indicators relative to those in Mainland areas. Also similar to the 2010 TDHS, respondents in urban areas are about one and a half times as likely as those in rural areas to show acceptance on all four indicators. Among females, the lowest acceptance was in Simiyu (6\% of those ages 15-19) and Geita (5\% of those ages 20-24), while the highest is in Mijini Magharibi (43\% of those ages 15-19) and Kilimanjaro (62\% of those ages 20-24). Among males, the lowest acceptance was also in Simiyu (15\% of those ages 15-19) and Dodoma (18\% of those ages 20-24), while the highest was in Dar es Salaam (52\% of those ages 15-19) and Mijini Magharibi (66\% of those ages 20-24) (see Annex Tables 36B1-2).

\begin{tabular}{|c|c|c|c|c|c|c|c|c|}
\hline \multicolumn{2}{|c|}{ Table 36B-1: Among Females Ages 15-24 Who Have Heard of AIDS, Percent Expressing Accepting Attitudes Towards People } \\
with AIDS (THMIS 2011-2012)
\end{tabular}

Note: Read the first column of data as "Percent of 15-19 year old females who would be willing to care for a family member with the AIDS virus in the respondent's home," using 2011-12 THMIS. 


\begin{tabular}{|c|c|c|c|c|c|c|c|c|c|c|}
\hline \multicolumn{11}{|c|}{ Sחוג } \\
\hline Region & \multicolumn{2}{|c|}{$\begin{array}{c}\text { Are willing to care } \\
\text { for a family member } \\
\text { with the AIDS virus } \\
\text { in the respondent's } \\
\text { home }\end{array}$} & \multicolumn{2}{|c|}{$\begin{array}{l}\text { Would buy fresh } \\
\text { vegetables from } \\
\text { shopkeeper who has } \\
\text { the AIDS virus }\end{array}$} & \multicolumn{2}{|c|}{$\begin{array}{l}\text { Say that a female } \\
\text { teacher with the } \\
\text { AIDS virus who is not } \\
\text { sick should be } \\
\text { allowed to continue } \\
\text { teaching }\end{array}$} & \multicolumn{2}{|c|}{$\begin{array}{l}\text { Would not want to } \\
\text { keep secret that a } \\
\text { family member got } \\
\text { infected with the } \\
\text { AIDS virus }\end{array}$} & \multicolumn{2}{|c|}{$\begin{array}{c}\text { Percent } \\
\text { expressing } \\
\text { acceptance on all } \\
\text { four indicators }\end{array}$} \\
\hline Mainland & 92.1 & 97.3 & 62.9 & 72.6 & 80.1 & 84.5 & 51.2 & 55.0 & 32.3 & 39.6 \\
\hline Zanzibar & 93.9 & 97.4 & 74.1 & 85.0 & 82.5 & 87.5 & 53.9 & 70.4 & 38.8 & 57.9 \\
\hline Urban & 96.9 & 98.7 & 79.4 & 85.6 & 89.9 & 94.8 & 57.4 & 61.6 & 45.4 & 51.8 \\
\hline Rural & 90.8 & 96.6 & 58.4 & 67.7 & 77.2 & 80.2 & 49.4 & 52.9 & 28.6 & 35.3 \\
\hline National & 92.2 & 97.3 & 63.3 & 73.1 & 80.2 & 84.6 & 51.3 & 55.5 & 32.6 & 40.2 \\
\hline
\end{tabular}

Note: Read the first column of data as "Percent of 15-19 year old males who would be willing to care for a family member with the AIDS virus in the respondent's home," using 2011-12 THMIS.

\subsection{HIV Testing and Counselling}

Knowing one's HIV serostatus can guide decision-making to reduce one's own HIV risk, to protect one's sexual partners, and to access treatment services as needed. To measure the awareness and coverage of HIV testing services in the TDHS and the THMIS, respondents were asked: (1) whether they had ever been tested for HIV; (2) if they had been tested, whether they had received the results of their last test; (3) the time since their last HIV test; and (4) if they knew of a place of where they could get tested.

Tables 37A1-2 and 37B1-2 provide data on awareness of HIV testing locations and HIV testing experience among females and males, according to the TDHS and THMIS, respectively. Taken together, data from both surveys show that awareness of HIV testing locations is high (about 8 in 10 of respondents aged 15-19, and 9 in 10 of respondents aged 20-24, respectively). The tables also show HIV testing increases substantially with age. Specifically, one in five girls ages $15-17$ (22\% in both TDHS and THMIS) and less than one-fifth of boys ages 15-17 (17\% in TDHS, and 22\% in THMIS) have ever been tested, while about three-quarters of girls ages 20-24 (71\% in TDHS and $78 \%$ and THMIS) and about half of boys ages 20-24 (45\% in TDHS and 52\% in THMIS) have ever been tested.

In both datasets, females and males ages 20-24 are most likely to have been tested for HIV, relative to younger aged adolescents (ages 15-17 or 18-19). Respondents in urban areas are more likely than those in rural areas to have had an HIV test. Youth residing in Mainland areas relative to Zanzibar are also more likely to have been tested and to have received their test results. Similar patterns are observed for HIV testing and receiving results in the past 12 months for females and males, though overall levels were much lower.

TDHS 2010: As shown in Annex Tables 37A1-2, regional variation in HIV testing exists. The proportion of females who ever had an HIV test and received results ranges from $12 \%$ in Kusini Unguja to $60 \%$ in Lindi among females ages 15-19, and from 45\% in Kaskazini Pemba to $89 \%$ in Mtwara among females ages 20-24. Among males, analysis of regional variation is limited by small sample size. 


\begin{tabular}{|c|c|c|c|c|c|c|c|c|}
\hline \multirow[b]{2}{*}{ Region } & \multicolumn{4}{|c|}{ Ever tested and received results } & \multicolumn{4}{|c|}{ Tested and received results in past 12 months } \\
\hline & $\begin{array}{l}\text { Ages } \\
15-17\end{array}$ & $\begin{array}{c}\text { Ages } \\
18-19\end{array}$ & $\begin{array}{c}\text { Ages } \\
15-19\end{array}$ & $\begin{array}{c}\text { Ages } \\
20-24\end{array}$ & $\begin{array}{l}15-17 \\
\text { years }\end{array}$ & $\begin{array}{l}\text { 18-19 } \\
\text { years }\end{array}$ & $\begin{array}{c}\text { Ages } \\
15-19\end{array}$ & $\begin{array}{l}\text { Ages } \\
20-24\end{array}$ \\
\hline Mainland & 19.7 & 48.5 & 29.9 & 67.9 & 14.0 & 33.3 & 20.9 & 38.2 \\
\hline Zanzibar & 7.7 & 24.5 & 13.9 & 52.7 & 5.9 & 16.3 & 9.7 & 28.1 \\
\hline Urban & 23.9 & 56.0 & 35.3 & 74.2 & 16.5 & 37.6 & 24.0 & 46.3 \\
\hline Rural & 17.2 & 44.0 & 26.8 & 64.0 & 12.6 & 30.6 & 19.0 & 33.7 \\
\hline National & 19.2 & 47.6 & 29.3 & 67.4 & 13.7 & 32.7 & 20.5 & 37.9 \\
\hline
\end{tabular}

Note: Read the first column of data as "Percent of 15-17 year old females who ever received HIV testing and the results of the last HIV test, "using 2010 TDHS.

\begin{tabular}{|c|c|c|c|c|c|c|c|c|}
\hline \multirow{2}{*}{ Region } & \multicolumn{4}{|c|}{ Ever tested and received results } & \multicolumn{4}{|c|}{ Tested and received results in past 12 months } \\
\hline & $\begin{array}{l}\text { Ages } \\
15-17\end{array}$ & $\begin{array}{l}\text { Ages } \\
18-19\end{array}$ & $\begin{array}{c}\text { Ages } \\
15-19\end{array}$ & $\begin{array}{c}\text { Ages } \\
20-24\end{array}$ & $\begin{array}{c}\text { Ages } \\
15-17\end{array}$ & $\begin{array}{c}\text { Ages } \\
18-19\end{array}$ & $\begin{array}{c}\text { Ages } \\
15-19\end{array}$ & $\begin{array}{c}\text { Ages } \\
20-24\end{array}$ \\
\hline Mainland & 15.6 & 22.7 & 18.3 & 42.6 & 12.1 & 15.1 & 13.2 & 27.9 \\
\hline Zanzibar & 3.5 & 17.9 & 9.5 & 35.1 & 2.5 & 13.8 & 7.1 & 25.9 \\
\hline Urban & 20.5 & 27.8 & 23.7 & 48.6 & 19.5 & 21.7 & 20.5 & 34.3 \\
\hline Rural & 13.7 & 20.3 & 16.1 & 39.7 & 9.5 & 12.3 & 10.5 & 25.2 \\
\hline National & 15.2 & 22.5 & 18.0 & 42.3 & 11.8 & 15.1 & 13.0 & 27.9 \\
\hline
\end{tabular}

Note: Read the first column of data as "Percent of 15-17 year old males who ever received HIV testing and the results of the last HIV test, “using 2010 TDHS.

THMIS 2011-12: Data presented in Annex Tables 37B1-2 also show marked regional variation in HIV testing among females and males. Rates of HIV testing among females ages 15-19 ranges from $11 \%$ in Kusini Pemba to 59\% in Lindi, and among females ages $20-24$ ranges from $57 \%$ in Kaskazini Unguja to 94\% Mtwara. Among males ages 15-19, HIV testing is least common in Geita, Kaskazini Unguja, and Kusini Pemba (6\%) and most common in Kilimanjaro (34\%). Among males ages 20-24, testing is least common in Kaskazini Pemba (14\%) and most common in Njombe (75\%).

\begin{tabular}{|c|c|c|c|c|c|c|}
\hline \multicolumn{2}{|c|}{ Table 37B-1: } & Percent of Females Ages 15-24 Who Have Been Tested for HIV and Received Results of their Last \\
Test (THMIS 2011-2012)
\end{tabular}

Note: Read the first column of data as "Percent of 15-17 year old females who ever received HIV testing and the results of the last HIV test," using 2011-12 THMIS. 


\begin{tabular}{|c|c|c|c|c|c|c|c|c|}
\hline \multicolumn{9}{|c|}{ Table 37B-2: } \\
\hline \multirow{2}{*}{ Region } & \multicolumn{4}{|c|}{ Ever tested and received results } & \multicolumn{4}{|c|}{ Tested and received results in past 12 months } \\
\hline & $\begin{array}{c}\text { Ages } \\
15-17\end{array}$ & $\begin{array}{c}\text { Ages } \\
18-19\end{array}$ & $\begin{array}{c}\text { Ages } \\
15-19\end{array}$ & $\begin{array}{c}\text { Ages } \\
20-24\end{array}$ & $\begin{array}{l}\text { Ages } \\
15-17\end{array}$ & $\begin{array}{l}\text { Ages } \\
18-19\end{array}$ & $\begin{array}{l}\text { Ages } \\
15-19\end{array}$ & $\begin{array}{l}\text { Ages } \\
20-24\end{array}$ \\
\hline Mainland & 14.9 & 28.2 & 20.2 & 48.8 & 11.8 & 20.2 & 15.2 & 37.0 \\
\hline Zanzibar & 3.4 & 15.7 & 8.2 & 44.6 & 2.4 & 11.1 & 5.8 & 28.5 \\
\hline Urban & 19.9 & 35.8 & 26.8 & 60.1 & 15.9 & 22.4 & 18.7 & 45.4 \\
\hline Rural & 13.0 & 25.0 & 17.6 & 43.8 & 10.3 & 19.0 & 13.6 & 33.0 \\
\hline National & 14.5 & 27.7 & 19.8 & 48.7 & 11.5 & 19.9 & 14.8 & 36.7 \\
\hline
\end{tabular}

Note: Read the first column of data as "Percent of 15-17 year old males who ever received HIV testing and the results of the last HIV test, “using 2011-12 THMIS.

\subsection{HIV Prevalence}

To obtain an updated estimate of HIV prevalence among the general population and to allow for improved monitoring of the epidemic, the 2011-12 THMIS conducted HIV testing among respondents. The methodology used for HIV testing is described in detail in the final report for the survey (see Technical Notes). Overall, $85 \%$ of THMIS respondents who were eligible for testing were interviewed and tested.

Figures 3, 4 and 5 show HIV point prevalence for females, males and all youth ages 15-24, respectively.

Annex Table 38 presents data on youth ages 15-24 who were interviewed and tested for HIV. HIV prevalence increases with age, and the risk of HIV infection increases enormously (almost 3.8 fold) for girls in their transition to adulthood (from 1.3\% among those ages 15-19, to 4.4\% among those ages 20-24). For males, HIV prevalence increases from $0.8 \%$ among those ages $15-19$, to $1.7 \%$ among those ages 20-24.

Annex Table 38 also displays variation in HIV positivity by area of residence, although these estimates should be interpreted with extreme caution. In general, seropositivity is higher among Mainland youth than Zanzibar youth. Seropositivity is also higher among urban youth than rural youth. Among Mainland areas, the highest prevalence estimate among adolescents ages 15-19 is in Dar es Salaam for females (4\%) and Dodoma and Kigoma for males (5\%, respectively). Among youth ages 20-24, the highest prevalence estimate is in Njombe among females (16\%) and Kagera among males (7\%). See Annex Table 39 for data on HIV prevalence among youth by specific year of age. 


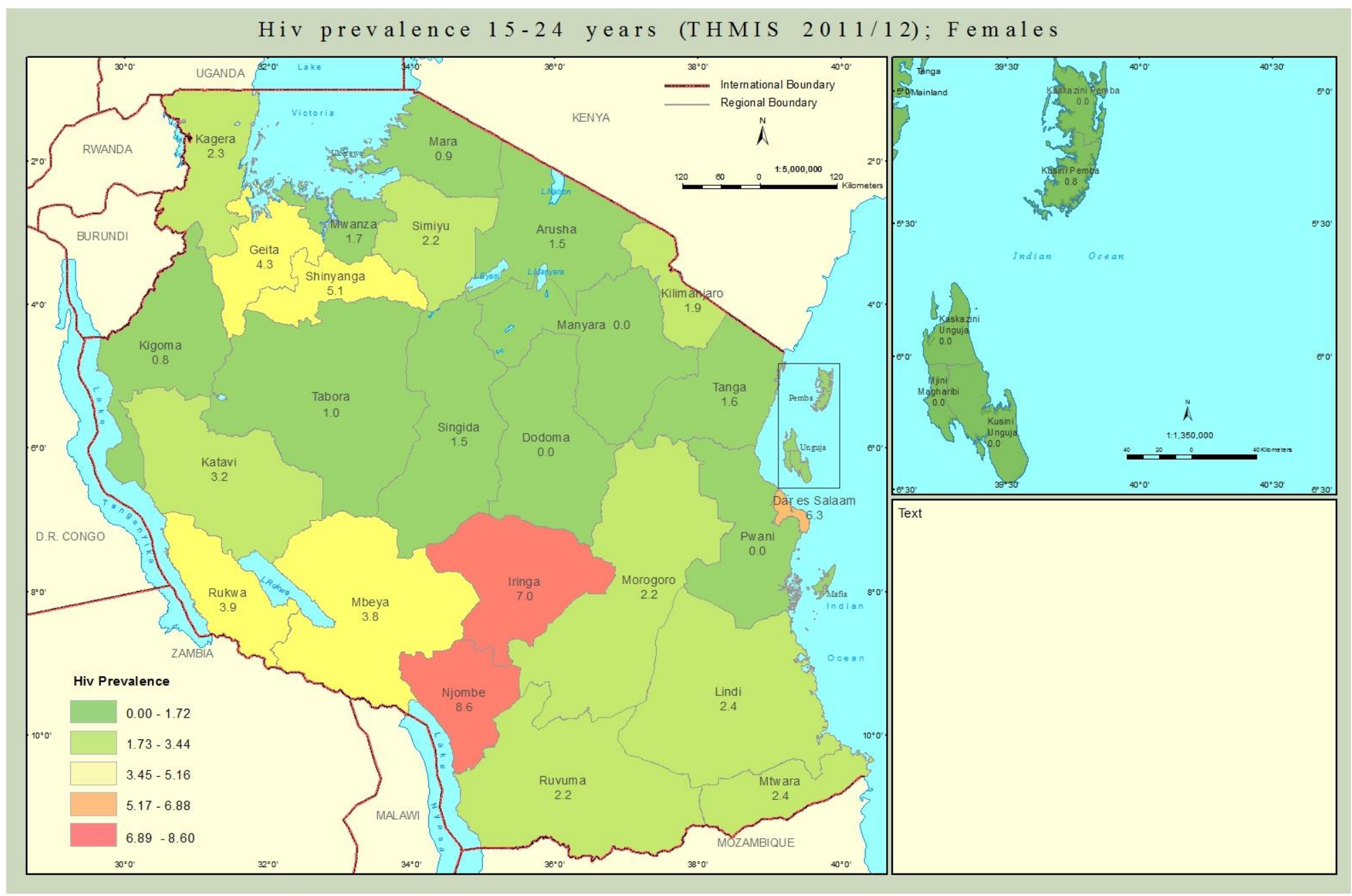

Figure 3. Regional HIV prevalence for females ages 15-24 in Tanzania, 2011-2012.

Source: TACAIDS et al. 2013. HIV/AIDS and Malaria Indicator Survey 2011-12. Dar es Salaam: Tanzania Commission for AIDS (TACAIDS), Zanzibar AIDS Commission, NBS, Office of the Chief Government Statistician, and ICF International. 


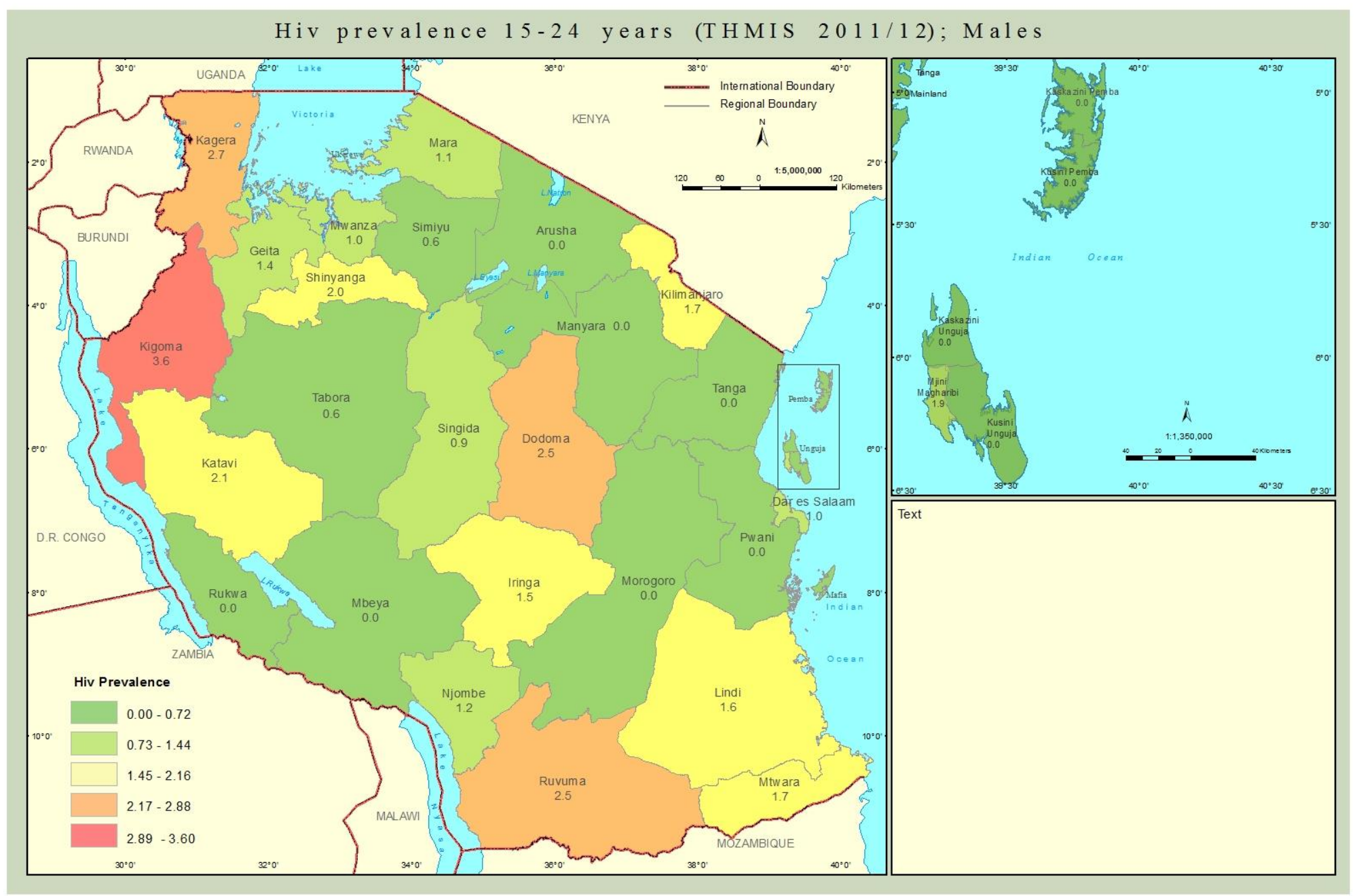

Figure 4. Regional HIV prevalence for males ages 15-24 in Tanzania, 2011-2012.

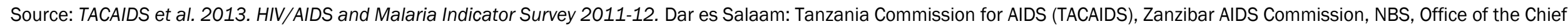
Government Statistician, and ICF International. 


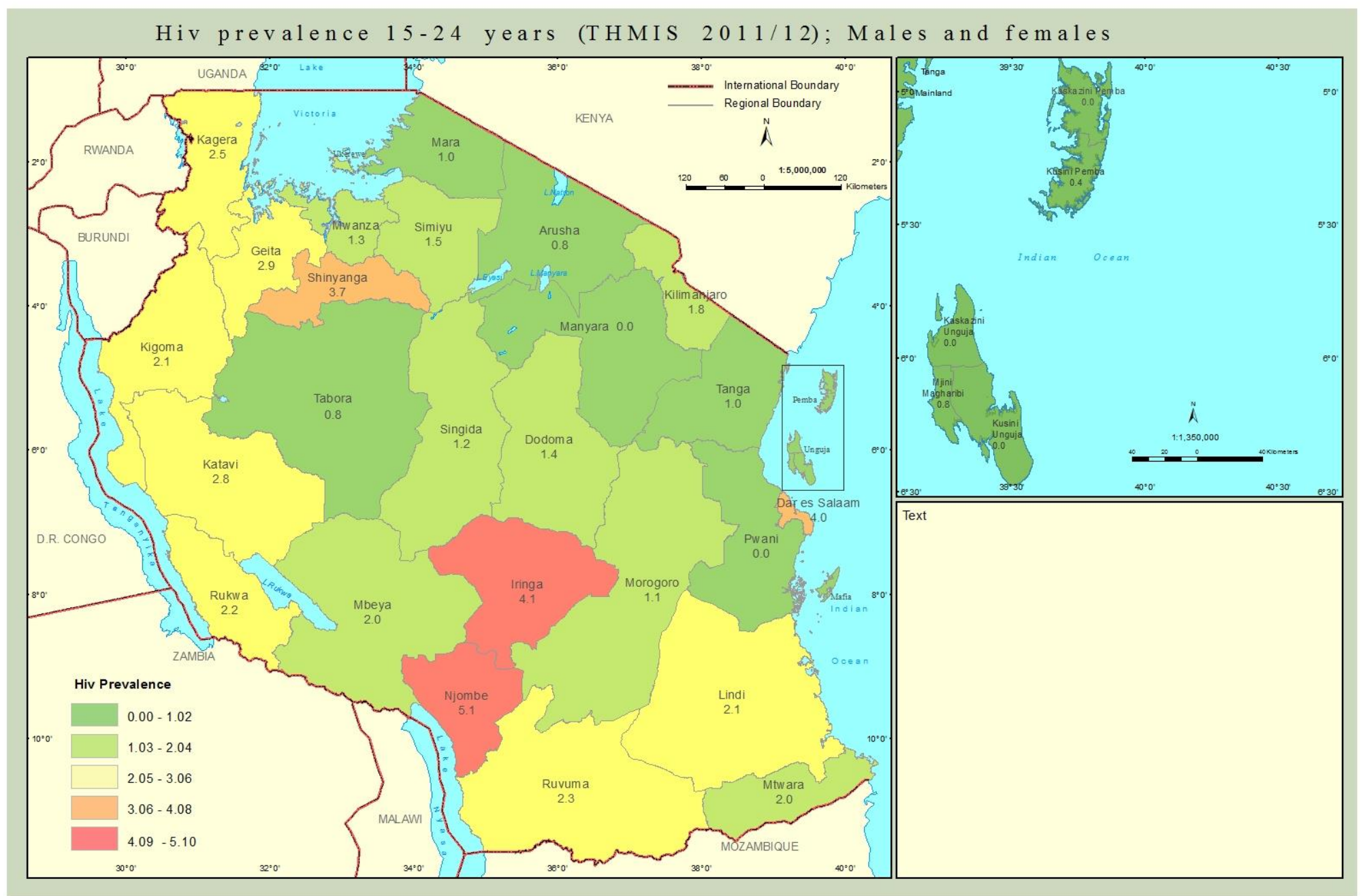

Figure 5. Regional HIV prevalence for youth ages 15-24 in Tanzania, 2011-2012.

Source: TACAIDS et al. 2013. HIV/AIDS and Malaria Indicator Survey 2011-12. Dar es Salaam: Tanzania Commission for AIDS (TACAIDS), Zanzibar AIDS Commission, NBS, Office of the Chief Government Statistician, and ICF International. 


\section{SEXUAL RISK BEHAVIOURS}

Information about sexual risk behaviour among youth is important to inform interventions to reduce unintended pregnancy and sexually transmitted infections, including HIV/AIDS (Doyle et al. 2012; Plummer 2012). This section presents data from the TDHS and THMIS. It should be noted, however, that self-reported survey information can be inaccurate due to a number of reasons, including poor recall, misunderstanding, or intentionally false statements made due to fear of criticism or embarrassment (Catania et al. 1993; Fenton et al. 2001; Turner et al. 2009). Self-reported data can be especially problematic in the study of a highly sensitive topic such as sexual behaviour, and particularly when it involves young people in sub-Saharan Africa, who may fear punishment for honest disclosure of sexual activity (Huygens et al. 1996; Cowan et al. 2002; Mensch et al. 2003; Beguy et al. 2009). In sub-Saharan Africa, as elsewhere in the world, adolescents tend to underreport sexual behaviours in surveys, but in some cases may over-report them, for example, if boys want to exaggerate their sexual experience to appear more masculine, or if individuals believe it is socially desirable to report a publically promoted behaviour, such as condom use (Catania et al. 1990; Agnew and Loving 1998; Devine and Aral 2004). With those caveats, the following section presents young people's reported sexual behaviour from the TDHS and the THMIS.

\subsection{Multiple Sexual Partners and Condom Use}

Tables 40A and 40B show that a relatively small percent of females and males ages 15-19 reported more than one sexual partner in the last 12 months (2\% of females in TDHS, $3 \%$ of females in THMIS; $7 \%$ of males in TDHS and THMIS). For youth ages 20-24 years, the percent of females reporting multiple sexual partners is only slightly greater (5\% of females in TDHS and THMIS), while for males it is substantially larger (21\% of males in TDHS and $23 \%$ in THMIS). In both surveys, youth who reside in Mainland areas tended to be more likely to have multiple partners than those residing in Zanzibar. Although limited by small sample sizes, data by region are presented in Annex Tables $40 \mathrm{~A}$ and $40 \mathrm{~B}$.

\begin{tabular}{|c|c|c|c|c|c|c|c|c|}
\hline \multirow[b]{2}{*}{ Region } & \multicolumn{4}{|c|}{ Females } & \multicolumn{4}{|c|}{ Males } \\
\hline & $\begin{array}{c}\text { Ages } \\
15-17\end{array}$ & $\begin{array}{c}\text { Ages } \\
18-19\end{array}$ & $\begin{array}{c}\text { Ages } \\
15-19\end{array}$ & $\begin{array}{c}\text { Ages } \\
20-24\end{array}$ & $\begin{array}{c}\text { Ages } \\
15-17\end{array}$ & $\begin{array}{c}\text { Ages } \\
18-19\end{array}$ & $\begin{array}{c}\text { Ages } \\
15-19\end{array}$ & $\begin{array}{c}\text { Ages } \\
20-24\end{array}$ \\
\hline Mainland & 0.9 & 4.0 & 2.0 & 4.9 & 4.2 & 11.7 & 7.0 & 21.4 \\
\hline Zanzibar & 0.0 & 0.3 & 0.1 & 0.8 & 0.7 & 2.0 & 1.2 & 1.7 \\
\hline Urban & 1.1 & 2.2 & 1.5 & 3.6 & 2.5 & 5.2 & 3.7 & 11.3 \\
\hline Rural & 0.8 & 4.5 & 2.1 & 5.3 & 4.6 & 13.8 & 7.9 & 24.8 \\
\hline National & 0.9 & 3.9 & 1.9 & 4.7 & 4.1 & 11.3 & 6.8 & 20.8 \\
\hline
\end{tabular}

Note: Read the first column of data as "Percent of 15-17 year old females who had more than one sexual partner in the 12 months preceding the survey," using 2010 TDHS.

\begin{tabular}{|c|c|c|c|c|c|c|c|c|}
\hline $\begin{array}{l}\text { Table 40B: } \\
\text { Months (THMIS 2011-2012) }\end{array}$ \\
\hline \multirow{3}{*}{ Region } & \multicolumn{9}{|c|}{ Females } \\
\cline { 2 - 10 } & Ages & Ages & Ages & Ages & Ages & Ages & Ages & Ages \\
& $15-17$ & $18-19$ & $15-19$ & $20-24$ & $15-17$ & $18-19$ & $15-19$ & $20-24$ \\
\hline Mainland & 2.8 & 3.5 & 3.1 & 4.8 & 4.5 & 11.4 & 7.2 & 23.8 \\
\hline Zanzibar & 0.2 & 0.0 & 0.1 & 0.3 & 0.4 & 5.2 & 2.3 & 4.4 \\
\hline Urban & 2.1 & 4.6 & 3.1 & 5.9 & 2.4 & 3.9 & 3.1 & 24.8 \\
\hline Rural & 2.9 & 3.0 & 2.9 & 4.2 & 4.9 & 13.7 & 8.3 & 22.3 \\
\hline National & 2.7 & 3.4 & 3.0 & 4.6 & 4.3 & 11.2 & 7.1 & 23.1 \\
\hline
\end{tabular}

Note: Read the first column of data as "Percent of 15-17 year old females who had more than one sexual partner in the 12 months preceding the survey," using 2011-12 THMIS. 
The youngest aged respondents were the least likely to have more than one sexual partner, while the reverse pattern is observed for condom use. Table $41 \mathrm{~A}$ and $41 \mathrm{~B}$ show that condom use during last sexual intercourse among males and females with more than one partner is highest among younger respondents. In the TDHS, 30\% of females ages 20-24 who reported multiple sex partners in the past year also reported using a condom at last sex; the proportion of 15-19 year old women reporting this was slightly higher (35\%). Similarly, 38\% of males aged $20-24$ reported this, compared to $34 \%$ of those aged 15-19. The same trend is observed in the THMIS. Small sample sizes limit the ability to examine condom use among those with multiple sex partners in the past year by region (Annex Tables 41A-B).

\begin{tabular}{|c|c|c|c|c|c|c|c|c|}
\hline \multirow[b]{2}{*}{ Region } & \multicolumn{4}{|c|}{ Females } & \multicolumn{4}{|c|}{ Males } \\
\hline & $\begin{array}{c}\text { Ages } \\
15-17\end{array}$ & $\begin{array}{c}\text { Ages } \\
18-19\end{array}$ & $\begin{array}{c}\text { Ages } \\
15-19\end{array}$ & $\begin{array}{c}\text { Ages } \\
20-24\end{array}$ & $\begin{array}{c}\text { Ages } \\
15-17\end{array}$ & $\begin{array}{c}\text { Ages } \\
18-19\end{array}$ & $\begin{array}{c}\text { Ages } \\
15-19\end{array}$ & $\begin{array}{c}\text { Ages } \\
20-24\end{array}$ \\
\hline Mainland & * & * & 35.3 & 29.9 & * & * & 34.2 & 37.9 \\
\hline Zanzibar & * & * & * & * & * & * & * & * \\
\hline Urban & * & * & * & * & * & * & * & * \\
\hline Rural & * & * & 38.4 & 28.5 & * & * & 35.1 & 36.3 \\
\hline National & * & * & 35.3 & 29.9 & * & * & 34.2 & 38.1 \\
\hline
\end{tabular}

Note: Read the first column of data as "Among 15-17 year old females who had more than one sexual partner in the 12 months preceding the survey, percent that used a condom at last sexual intercourse," using 2010 TDHS. Figures in highlighted cells are based on 25-50 unweighted cases; highlighted figures marked with an asterisk are based on less than 25 unweighted cases.

\begin{tabular}{|c|c|c|c|c|c|c|c|c|}
\hline \multirow[b]{2}{*}{ Region } & \multicolumn{4}{|c|}{ Females } & \multicolumn{4}{|c|}{ Males } \\
\hline & $\begin{array}{c}\text { Ages } \\
15-17\end{array}$ & $\begin{array}{c}\text { Ages } \\
18-19\end{array}$ & $\begin{array}{c}\text { Ages } \\
15-19\end{array}$ & $\begin{array}{c}\text { Ages } \\
20-24\end{array}$ & $\begin{array}{c}\text { Ages } \\
15-17\end{array}$ & $\begin{array}{c}\text { Ages } \\
18-19\end{array}$ & $\begin{array}{c}\text { Ages } \\
15-19\end{array}$ & $\begin{array}{c}\text { Ages } \\
20-24\end{array}$ \\
\hline Mainland & 46.2 & 27.9 & 37.8 & 30.9 & 44.7 & 44.6 & 44.6 & 38.7 \\
\hline Zanzibar & * & * & * & * & * & * & * & 60.8 \\
\hline Urban & * & * & * & * & * & * & * & 49.1 \\
\hline Rural & * & * & * & * & * & * & * & 33.9 \\
\hline National & 46.1 & 27.9 & 37.7 & 30.8 & 44.5 & 45.5 & 45.2 & 38.8 \\
\hline
\end{tabular}

Note: Read the first column of data as "Among 15-17 year old females who had more than one sexual partner in the 12 months preceding the survey, percent that used a condom at last sexual intercourse," using 2011-12 THMIS.

Figures in highlighted cells are based on 25-50 unweighted cases; highlighted figures marked with an asterisk are based on less than 25 unweighted cases.

\subsection{Paid Sex in Last 12 Months and Condom use (Males)}

Transactional sex in Tanzania usually involves a boy or man giving a girl or woman money or a gift in exchange for a sexual encounter. This is a widespread practice among sexually active, unmarried youth in Tanzania (Nnko and Pool 1997; Silberschmidt and Rasch 2001; Wamoyi et al. 2010), as it is in many parts of sub-Saharan Africa (Caldwell, Caldwell, and Quiggin 1989; Hunter 2002; Dunkle et al. 2004; Tawfik and Watkins 2007; Boileau et al. 2008). Such material exchange for sex partly reflects girls' poverty and limited access to the cash economy relative to boys, but it also relates to cultural values about reciprocity and self-esteem (Plummer and Wight 2011). Much less common is the practice of commercial sex work, which is stigmatizing for the girls and women who engage in it.

The THMIS asked males whether they had paid for sex in the 12 months preceding the survey and if they used a condom during their last paid sexual encounter. Table 42 shows that $15 \%$ of males aged $15-19$ and $16 \%$ of those aged $20-24$ reported paying for sexual intercourse in the last 12 
months. Reports of paid sex by males ages 15-19 were more common in rural than urban areas (17\% compared to $4 \%$ ), and also among Mainland young men when compared to those in Zanzibar.

\begin{tabular}{|c|c|c|c|c|c|c|c|c|}
\hline \multirow{3}{*}{ Region } & \multicolumn{4}{|c|}{ Among all men } & \multicolumn{4}{|c|}{$\begin{array}{l}\text { Among men who paid for sex in past } 12 \\
\text { months }\end{array}$} \\
\hline & \multicolumn{4}{|c|}{$\begin{array}{l}\text { Percent who paid for sexual intercourse in } \\
\text { past } 12 \text { months }\end{array}$} & \multicolumn{4}{|c|}{$\begin{array}{c}\text { Percent reporting condom use at last paid } \\
\text { sexual intercourse }\end{array}$} \\
\hline & $\begin{array}{l}\text { Ages } \\
15-17\end{array}$ & $\begin{array}{l}\text { Ages } \\
18-19 \\
\end{array}$ & $\begin{array}{l}\text { Ages } \\
15-19\end{array}$ & $\begin{array}{l}\text { Ages } \\
20-24\end{array}$ & $\begin{array}{l}\text { Ages } \\
15-17\end{array}$ & $\begin{array}{l}\text { Ages } \\
18-19\end{array}$ & $\begin{array}{l}\text { Ages } \\
15-19\end{array}$ & $\begin{array}{l}\text { Ages } \\
20-24\end{array}$ \\
\hline Mainland & 15.8 & 13.9 & 14.7 & 16.3 & 33.3 & 42.0 & 37.9 & 51.8 \\
\hline Zanzibar & 0.0 & 4.4 & 2.7 & 0.5 & * & * & * & * \\
\hline Urban & 4.7 & 3.7 & 4.0 & 13.6 & * & * & * & 60.9 \\
\hline Rural & 17.3 & 16.9 & 17.1 & 17.2 & 31.7 & 42.7 & 37.5 & 48.7 \\
\hline National & 15.7 & 13.8 & 14.6 & 16.1 & 33.3 & 41.9 & 37.9 & 51.8 \\
\hline
\end{tabular}

Note: Read the first column of data as "Percent of 15-17 year old males who paid for sex in the 12 months preceding the survey," using 2011-12 THMIS. Figures in highlighted cells are based on 25-50 unweighted cases; highlighted figures marked with an asterisk are based on less than 25 unweighted cases.

About half of males ages 20-24 reported they used a condom the last time they paid for sex, while slightly more than one-third of males ages 15-19 reported this. Due to the small number of men who reported transactional sex, it is not possible to examine differences in condom use by age or area of residence.

\subsection{Attitudes Towards Negotiating Condom Use with Husband}

Regardless of marital status, girls and young women often are at a disadvantage when negotiating condom use with a sexual partner, because of power dynamics related to their gender, youth, and financial dependence (Bogale et al. 2010; Maticka-Tyndale and Kyeremeh 2010; Plummer 2012). Limited negotiating power for condom use may place adolescent girls at increased risk of sexually transmitted infections (STIS), HIV, and unintended pregnancy.

2010 TDHS: Table 43A shows that about three-fourths (76\%) of females ages $15-19$ and $83 \%$ of those ages 20-24 believe that if a woman's husband has a STI, she is justified in asking that he use a condom. A slightly lower percent of younger females believe a woman is justified in this circumstance ( $72 \%$ of those ages 15-17). The table also shows that a lower proportion of females in Zanzibar than in Mainland areas agree that a woman is justified in asking for condom use, across age groups. Females in rural than in urban areas were less likely to support women's empowerment to use condoms in this instance (e.g., $81 \%$ of those ages $15-19$ in urban areas, and $73 \%$ in rural areas).

Table 43A: Percent of Females Ages 15-24 Who Believe, If Husband Has a
Sexually Transmitted Disease, His Wife is Justified in Asking that He Use a
Condom (DHS, 2010)
\begin{tabular}{|l|c|c|c|c|}
\hline \multirow{2}{*}{ Region } & Ages & Ages & Ages & Ages \\
& $15-17$ & $18-19$ & $15-19$ & $20-24$ \\
\hline Mainland & 72.9 & 82.8 & 76.4 & 82.9 \\
\hline Zanzibar & 50.9 & 63.4 & 55.6 & 73.3 \\
\hline Urban & 79.2 & 85.0 & 81.3 & 88.9 \\
\hline Rural & 69.0 & 80.9 & 73.3 & 79.5 \\
\hline National & 72.1 & 82.1 & 75.7 & 82.6 \\
\hline
\end{tabular}

Note: Read the first column of data as "Percent of 15-17 year old females who believe if husband has a STI, his wife is justified in asking that he use a condom," using 2010 TDHS. 
2011-12 THMIS: Table 43B shows that a similarly high percent of females ages 15-19 and 20-24 believe that, if a woman's husband has a STI, she is justified in asking that he use a condom $(70 \%$ and $82 \%$, respectively). A slightly lower percent of younger females believe a woman is justified in doing this (64\% of those ages 15-17). Also, reflecting patterns observed in the 2010 TDHS data, a lower proportion of females in Zanzibar than in the Mainland agree that a woman is justified in this, across age groups. Lower proportions of females in rural relative to urban areas also supported women's empowerment towards condom use.

\begin{tabular}{|c|c|c|c|c|}
\hline Region & $\begin{array}{c}\text { Ages } \\
15-17\end{array}$ & $\begin{array}{c}\text { Ages } \\
18-19\end{array}$ & $\begin{array}{c}\text { Ages } \\
15-19\end{array}$ & $\begin{array}{c}\text { Ages } \\
20-24\end{array}$ \\
\hline Mainland & 64.8 & 79.6 & 70.8 & 82.5 \\
\hline Zanzibar & 40.1 & 57.1 & 47.1 & 72.3 \\
\hline Urban & 74.5 & 90.1 & 80.4 & 89.4 \\
\hline Rural & 59.7 & 74.9 & 66.0 & 79.3 \\
\hline National & 63.8 & 78.7 & 69.8 & 82.1 \\
\hline
\end{tabular}

Note: Read the first column of data as "Percent of 15-17 year old females who believe if husband has a STI, his wife is justified in asking that he use a condom," using 2011-12 THMIS.

Although limited by small sample sizes, additional tables by region can be found in Annex Tables $43 \mathrm{~A}$ and $43 \mathrm{~B}$.

\subsection{Condom Use During Premarital Sex}

Youth who practice low-risk behaviours such as condom use from the onset of their sexual activity are more likely to continue those behaviours as they get older than youth who have established high-risk behaviours (Gallant and Maticka-Tyndale 2004). Reported condom use at first sex thus can serve as an indicator of reduced risk of exposure at the beginning of sexual activity, if the reports are valid. In addition, the period between first premarital sex and marriage may be a time of relatively great sexual experimentation (such as frequent partner change), which in HIV prevalent areas can mean increased risk of exposure.

2010 TDHS: Table 44A shows that across the ages of 15 to 24, approximately half of never-married females who reported sex in the past 12 months also reported condom use at their last sexual intercourse (49\% of females ages $15-17,52 \%$ of females ages $18-19$, and $48 \%$ of those ages 20 24). Young women in urban areas ages $15-19$ and 20-24 are slightly more likely than those in rural areas to report sex in the last year and condom use at last sex ( $54 \%$ and $51 \%$, respectively). Table 44B shows that, although condom use is lower among males ages 15-17 compared to same-aged females (38\% versus 49\%), a higher proportion of males ages $20-24$ reported condom use at last sexual intercourse compared to girls of the same age (60\% versus $48 \%$ ). The low number of young women and men who reported sex in the past year limits the assessment of reporting by area of residence. 
Table 44A: Of Never-Married Females Ages 15-24 who Had Sex in Past 12 Months, Percent who Reported Condom Use at Last Sexual Intercourse (DHS, 2010)

\begin{tabular}{|c|c|c|c|c|}
\hline Region & $\begin{array}{c}\text { Ages } \\
15-17\end{array}$ & $\begin{array}{c}\text { Ages } \\
18-19\end{array}$ & $\begin{array}{c}\text { Ages } \\
15-19\end{array}$ & $\begin{array}{c}\text { Ages } \\
20-24\end{array}$ \\
\hline Mainland & 48.7 & 52.2 & 50.3 & 47.8 \\
\hline Zanzibar & $\star$ & $\star$ & $\star$ & * \\
\hline Urban & 58.0 & 50.9 & 48.2 & 51.2 \\
\hline Rural & 45.0 & 52.8 & 50.2 & 43.5 \\
\hline National & 48.7 & 52.1 & 50.2 & 47.6 \\
\hline
\end{tabular}

Note: Read the first column of data as "Of never-married females ages 15-17 who reported having had sex in the past 12 months, percent who reported condom use at last sexual intercourse," using 2010 TDHS. Highlighted figures marked with an asterisk are based on less than 25 unweighted cases.

Table 44B: Of Never-Married Males Ages 15-24 who Had Sex in Past 12 Months, Percent who Reported Condom Use at Last Sexual Intercourse (DHS, 2010)

\begin{tabular}{|c|c|c|c|c|}
\hline \multirow{2}{*}{ Region } & Ages & Ages & Ages & Ages \\
& $15-17$ & $18-19$ & $15-19$ & $20-24$ \\
\hline Mainland & 38.4 & 53.1 & 46.4 & 60.6 \\
\hline Zanzibar & $\star$ & $*$ & $*$ & * \\
\hline Urban & 42.7 & 60.2 & 52.6 & 75.3 \\
\hline Rural & 37.1 & 51.3 & 44.7 & 53.2 \\
\hline National & 38.0 & 52.9 & 46.1 & 60.4 \\
\hline
\end{tabular}

Note: Read the first column of data as "Of never-married males ages 15-17 who reported having had sex in the past 12 months, percent who reported condom use at last sexual intercourse," using 2010 TDHS. Figures in highlighted cells are based on 25-50 unweighted cases; highlighted figures marked with an asterisk are based on less than 25 unweighted cases. 


\section{REPRODUCTIVE AND MATERNAL HEALTH}

This chapter presents findings about several areas of importance to maternal health, including youth use of contraceptive methods, experience of antenatal and delivery care, and exposure to mass media. These topics relate to national and global objectives to reduce maternal morbidity and mortality.

\subsection{Current Contraceptive Use by Marital Status}

Ensuring contraceptive choice and safety is crucial to adolescent sexual and reproductive health. Lack of access to and limited use of modern contraceptives are major causes of unintended pregnancies (Williamson et al. 2009). Adolescents have significantly higher unmet need for modern contraception than the general population (Population Council 2004).

2010 TDHS: Table 45 presents data on current contraceptive use by marital status. Two in 10 (21\%) currently married females ages 15-24 reported using a modern contraceptive method, while three in ten never-married sexually experienced females reported the same. A greater proportion of females in Mainland areas (21\% of those currently-married, and $29 \%$ of those sexually experienced and never-married) reported using modern contraception relative than females in Zanzibar (14\% of those currently-married, and $0 \%$ of those sexually experienced and never-married). Urban girls and young women who are currently married are twice as likely to be using a modern contraceptive method $(32 \%)$ as those in rural areas (14\%), while an equivalent proportion of sexually experienced nevermarried females use modern contraception in both areas. Additional information by region is provided in Annex Table 45, but findings are limited by small sample sizes. Currently- married females ages 15-19 are half as likely to use any modern contraceptive method than those ages 2024 (12\% versus $24 \%$ ). Among never-married females who are sexually experienced, 35\% of those ages $15-19$ and $48 \%$ of those ages $20-24$ report current use of a modern contraception (data not shown).

\begin{tabular}{|c|c|c|}
\hline Region & Currently-married & $\begin{array}{c}\text { Never married (and ever } \\
\text { had sex) }\end{array}$ \\
\hline Mainland & 21.1 & 29.3 \\
\hline Zanzibar & 13.7 & 0.0 \\
\hline Urban & 32.1 & 29.0 \\
\hline Rural & 17.8 & 29.2 \\
\hline National & 20.9 & 29.1 \\
\hline \multicolumn{3}{|c|}{$\begin{array}{l}\text { Read the first column of data as "Of currently-married females ages 15-24, } \\
\text { percent who are currently using a modern contraceptive method," using } 2010 \\
\text { TDHS. a Including: female sterilization, oral contraceptive, intrauterine device, } \\
\text { injectable, implant, male condom, and the lactational amenorrhea method. }\end{array}$} \\
\hline
\end{tabular}

\section{2. $\quad$ Antenatal Care During Most Recent Pregnancy}

Antenatal care (ANC) is most effective in preventing adverse pregnancy outcomes when accessed early and throughout pregnancy (Lawn and Kerber 2006). WHO guidelines recommend that a pregnant woman without complications have at least four ANC visits for sufficient care.

Table 46 shows the mean number of ANC visits during the most recent pregnancy of 15-24 year olds who had had a live birth in the five years preceding the survey. There was not great variation in antenatal care by age group, which is on average three visits. The mean number of ANC visits is 64 
slightly lower among younger respondents than older ones (3.1\% of those ages $15-17$, and $3.4 \%$ of those ages 20-24), although the discrepancy is marginal. Mean ANC visits are also slightly lower in rural areas relative to urban areas, as well as in Mainland Tanzania relative to Zanzibar.

\begin{tabular}{|c|c|c|c|c|}
\hline \multicolumn{4}{|c|}{ Table 46: } & Mean Number of Antenatal Care Visits a among Females Ages 15-24 (DHS, 2010) \\
\hline Region & $\begin{array}{c}\text { Ages } \\
15-17\end{array}$ & $\begin{array}{c}\text { Ages } \\
18-19\end{array}$ & $\begin{array}{c}\text { Ages } \\
15-19\end{array}$ & $\begin{array}{c}\text { Ages } \\
20-24\end{array}$ \\
\hline Mainland & 3.13 & 3.32 & 3.26 & 3.43 \\
\hline Zanzibar & $*$ & $*$ & 3.83 & 3.79 \\
\hline Urban & $*$ & 3.44 & 3.65 & 3.93 \\
\hline Rural & 2.83 & 3.29 & 3.16 & 3.28 \\
\hline National & 3.14 & 3.32 & 3.26 & 3.44 \\
\hline
\end{tabular}

Read the first column of data as "Mean number of antenatal care visits among females ages 15-24 who gave birth in last 5 years preceding the survey," using 2010 TDHS. a For most recent birth in last 5 years preceding the survey. Figures in highlighted cells are based on 25-50 unweighted cases; highlighted figures marked with an asterisk are based on less than 25 unweighted cases.

\section{3. $\quad$ Birth Attendance During Delivery}

The type of assistance received during childbirth is often used as an indicator of the quality of maternal and postnatal infant care. Annex Table 47 shows the percent distribution of births in the five years preceding the survey by type of assistance during delivery among girls and young women. If more than one person was in attendance, only the provider with the highest qualifications was considered during data collection.

During their most recent delivery, more than half of females (62\% ages $15-19$, and $58 \%$ ages $20-24$ ) were assisted by a health professional (i.e., doctors, clinical officers, nurses, midwives and maternal and child health aides). One in ten births was assisted by a traditional birth attendant, while approximately three in ten were assisted by a friend or village health worker, with little variation by age. Urban females were more likely to deliver in the presence of a health professional (85\% ages $15-19 ; 86 \%$ ages $20-24$ ) relative to rural females (54\% ages $15-19 ; 48 \%$ ages $20-24$ ). Of note is that 20-24 year old females with residence in Zanzibar were much more likely to deliver with a traditional birth attendant than those in Mainland Tanzania (36\% compared to $12 \%$, respectively). 


\section{EXPOSURE TO MASS MEDIA}

Mass media can be a major mechanism for dissemination of public health information, including sexual and reproductive health messages (Bertrand and Anhang 2006). Information about access to various types of media allows policymakers to use the most effective means of communication for various young populations, and can also shed light on gender differences that may contribute to inequalities in access to information.

The TDHS and the THMIS collected information on respondents' exposure to various forms of print and electronic media. Respondents were asked how often they read a newspaper, listened to the radio, or watched television in a week. The 2011-2012 THMIS survey additionally asked individual respondents if they had access to a mobile phone.

2010 TDHS: Table 48A shows the percent of females ages 15-24 who have access to at least one of three types of media (newspaper/magazine, television, or radio) at least once per week. Two-thirds of females (70\% of those ages 15-19; $67 \%$ of those ages $20-24$ ) access at least one of the three media sources once or more per week, compared to $79 \%$ and $83 \%$ of boys ages 15-19 and 20-24, respectively (data not shown). Rural females are nearly four times more likely to lack access to all three media sources compared to urban females (39\% vs. 9\% among females ages $15-19 ; 43 \%$ vs. $14 \%$ among females ages 20-24, respectively). Females in Zanzibar also have higher levels of access relative to those in Mainland areas.

Access to media sources also varies greatly by region, with Ruvuma having the highest percent of girls ages 15-19 with access to none of the three media sources a least per week (56\%), and Dar es Salaam and Mjini Magharibi having the lowest percent of same-aged girls without access ( $4 \%$ and $10 \%$, respectively).

Of the different forms of media, females are most likely to listen to the radio (60\% of those ages 15$19,59 \%$ of those ages $20-24$ ), followed by watching the television (32\% of those ages $15-19 ; 28 \%$ of those ages 20-24), and or reading a newspaper or magazine (27\% of those ages 15-19; $19 \%$ ages 20-24). Women ages 20-24 have slightly lower access levels than 15-19 year old girls and women. See Annex Table 48A for additional data on media source and age groups. 


\begin{tabular}{|c|c|c|c|c|}
\hline \multicolumn{5}{|c|}{$\begin{array}{c}\text { Table 48A: Percent of Females Ages 15-24 Who Are Exposed to Specific Media } \\
\text { on at Least a Weekly Basis (DHS, 2010) }\end{array}$} \\
\hline \multirow[t]{2}{*}{ Region } & \multicolumn{2}{|c|}{$\begin{array}{l}\text { Accesses at least one of } \\
\text { three media sources } \\
\text { (newspaper/magazine, TV, } \\
\text { radio) at least once a week }\end{array}$} & \multicolumn{2}{|c|}{$\begin{array}{l}\text { Accesses none of the three } \\
\text { media at least once a week }\end{array}$} \\
\hline & $\begin{array}{l}\text { Ages } \\
15-19\end{array}$ & $\begin{array}{l}\text { Ages } \\
20-24\end{array}$ & $\begin{array}{l}\text { Ages } \\
15-19\end{array}$ & $\begin{array}{l}\text { Ages } \\
20-24\end{array}$ \\
\hline \multicolumn{5}{|l|}{ Mainland } \\
\hline Arusha & 76.5 & 62.0 & 23.5 & 38.0 \\
\hline Dar es Salaam & 95.9 & 90.6 & 4.1 & 9.4 \\
\hline Dodoma & 53.9 & 47.9 & 46.1 & 52.1 \\
\hline Iringa & 68.1 & 80.0 & 31.9 & 20.0 \\
\hline Kagera & 67.7 & 76.0 & 32.3 & 24.0 \\
\hline Kigoma & 85 & 67.7 & 15.0 & 32.3 \\
\hline Kilimanjaro & 82.8 & 82.0 & 17.2 & 18.0 \\
\hline Lindi & 48.4 & 63.5 & 51.6 & 36.5 \\
\hline Manyara & 53.0 & 46.0 & 47.0 & 54.0 \\
\hline Mara & 49.7 & 49.3 & 50.3 & 50.7 \\
\hline Mbeya & 81.0 & 75.5 & 19.0 & 24.5 \\
\hline Morogoro & 91.0 & 67.1 & 9.0 & 32.9 \\
\hline Mtwara & 63.7 & 56.0 & 36.3 & 44.0 \\
\hline Mwanza & 55.8 & 45.1 & 44.2 & 54.9 \\
\hline Pwani & 82.1 & 80.1 & 17.9 & 19.9 \\
\hline Rukwa & 66.6 & 65.0 & 33.4 & 35.0 \\
\hline Ruvuma & 44.2 & 61.8 & 55.8 & 38.2 \\
\hline Shinyanga & 68.2 & 64.3 & 31.8 & 35.7 \\
\hline Singida & 66.1 & 74.6 & 33.9 & 25.4 \\
\hline Tabora & 56.6 & 53.3 & 43.4 & 46.7 \\
\hline Tanga & 72.1 & 57.6 & 27.9 & 42.4 \\
\hline \multicolumn{5}{|l|}{ Zanzibar } \\
\hline Kaskazini Unguja & 74.1 & 73.6 & 25.9 & 26.4 \\
\hline Kusini Unguja & 87.3 & 94.3 & 12.7 & 5.7 \\
\hline Mjini Magharibi & 89.9 & 95.4 & 10.1 & 4.6 \\
\hline Kaskazini Pemba & 62.9 & 65.5 & 37.1 & 34.5 \\
\hline Kusini Pemba & 80.6 & 86.5 & 19.4 & 13.5 \\
\hline Mainland & 69.9 & 66.3 & 30.1 & 33.7 \\
\hline Zanzibar & 79.9 & 85.4 & 20.1 & 14.6 \\
\hline Urban & 91 & 86.1 & 9 & 13.9 \\
\hline Rural & 61.4 & 57.5 & 38.6 & 42.5 \\
\hline National & 70.2 & 66.9 & 29.8 & 33.1 \\
\hline
\end{tabular}

Notes: Read the first column of data as "Percent of females ages 15-19 who have access to at least one of three media sources (newspaper/magazine, radio, or television) at least once per week," using 2010 TDHS. Figures in highlighted cells are based on 25-50 unweighted cases. 
2011-12 THMIS: This survey measured access to four types of media, including weekly access to a newspaper/magazine, television, or radio, or ownership of a mobile phone. Table 48B shows that 6 in 10 females (62\% ages 15-19; 67\% of ages 20-24) have access at least one of the four media sources. Boys are more likely than girls to have a mobile phone, and have access to newspaper/magazine, television and radio (data not shown). Similar to TDHS findings, rural females have lower levels of media access than urban females. Specifically, rural females ages 15-19 are three times more likely to lack access to all four media sources compared to their urban counterparts (46\% versus $15 \%$, respectively). The urban-rural discrepancy was even more pronounced among females ages 20-24, as rural 20-24 year olds were 5 times more likely to lack access to all four media sources than their urban counterparts ( $42 \%$ versus $8 \%$, respectively). Females in Zanzibar also have higher levels of access relative to those in Mainland areas. This pattern is most evident among females ages 20-24 (86\% have access to at least one source in Zanzibar, compared to $66 \%$ in Mainland areas).

Also similar to the TDHS is that females are most likely to listen to the radio (48\% of those ages 15$19 ; 50 \%$ of those ages $20-24$ ) and are least likely to read a newspaper or magazine (16\% of those ages 15-19; $12 \%$ of those ages 20-24). A higher percent of women ages $20-24$ have a mobile phone compared to those ages $15-19$ (37\% versus $16 \%$, respectively). Approximately one-quarter of girls watch television once per week. This finding does not vary meaningfully by age (25\% of those ages $15-19 ; 23 \%$ of those ages 20-24). See Annex Table 48B for data on access to media specific sources by additional age groups. 


\begin{tabular}{|c|c|c|c|c|}
\hline \multicolumn{5}{|c|}{$\begin{array}{cc}\text { Table 48B: } & \text { Percent of Females Ages 15-24 Who Are Exposed to Specific Media on } \\
\text { at Least a Weekly Basis (THMIS 2011-2012) }\end{array}$} \\
\hline \multirow[t]{2}{*}{ Region } & \multicolumn{2}{|c|}{$\begin{array}{l}\text { Has access to at least } 1 \text { of } \\
\quad 4 \text { sources } \\
\text { (newspaper/magazine, TV, } \\
\text { radio at least once a week) } \\
\text { or individual has mobile } \\
\text { phone }\end{array}$} & \multicolumn{2}{|c|}{$\begin{array}{l}\text { Has access to none of the } 4 \\
\text { sources } \\
\text { (newspaper/magazine, TV, } \\
\text { radio at least once a week) or } \\
\text { individual has no mobile } \\
\text { phone }\end{array}$} \\
\hline & $\begin{array}{l}\text { Ages } \\
15-19\end{array}$ & $\begin{array}{l}\text { Ages } \\
20-24\end{array}$ & $\begin{array}{l}\text { Ages } \\
15-19\end{array}$ & $\begin{array}{l}\text { Ages } \\
20-24\end{array}$ \\
\hline \multicolumn{5}{|l|}{ Mainland } \\
\hline Arusha & 63.8 & 61.1 & 36.2 & 38.9 \\
\hline Dar es Salaam & 90.4 & 96.5 & 9.6 & 3.5 \\
\hline Dodoma & 53.3 & 41.8 & 46.7 & 58.2 \\
\hline Geita & 57.6 & 61.4 & 42.4 & 38.6 \\
\hline Iringa & 59.7 & 72.8 & 40.3 & 27.2 \\
\hline Kagera & 65.9 & 63.3 & 34.1 & 36.7 \\
\hline Katavi & 47.6 & 41.8 & 52.4 & 58.2 \\
\hline Kigoma & 71.2 & 82.1 & 28.8 & 17.9 \\
\hline Kilimanjaro & 67.9 & 89.7 & 32.1 & 10.3 \\
\hline Lindi & 61.0 & 71.5 & 39.0 & 28.5 \\
\hline Manyara & 37.7 & 63.8 & 62.3 & 36.2 \\
\hline Mara & 55.9 & 60.8 & 44.1 & 39.2 \\
\hline Mbeya & 70.2 & 72.7 & 29.8 & 27.3 \\
\hline Morogoro & 82.6 & 73.5 & 17.4 & 26.5 \\
\hline Mtwara & 67.9 & 74.2 & 32.1 & 25.8 \\
\hline Mwanza & 61.2 & 59.2 & 38.8 & 40.8 \\
\hline Njombe & 70.4 & 82.1 & 29.6 & 17.9 \\
\hline Pwani & 72.1 & 76.4 & 27.9 & 23.6 \\
\hline Rukwa & 47.6 & 57.9 & 52.4 & 42.1 \\
\hline Ruvuma & 67.8 & 57.1 & 32.2 & 42.9 \\
\hline Shinyanga & 39.5 & 45.6 & 60.5 & 54.4 \\
\hline Simiyu & 22.7 & 33.4 & 77.3 & 66.6 \\
\hline Singida & 63.8 & 54.4 & 36.2 & 45.6 \\
\hline Tabora & 63.9 & 66.2 & 36.1 & 33.8 \\
\hline Tanga & 53.5 & 63.5 & 46.5 & 36.5 \\
\hline \multicolumn{5}{|l|}{ Zanzibar } \\
\hline Kaskazini & 59.7 & 70.4 & 40.3 & 29.6 \\
\hline Kusini & 87.0 & 98.2 & 13.0 & 1.8 \\
\hline Mjini Magharibi & 77.3 & 91.5 & 22.7 & 8.5 \\
\hline Kaskazini Pemba & 72.1 & 83.5 & 27.9 & 16.5 \\
\hline Kusini Pemba & 60.8 & 73.5 & 39.2 & 26.5 \\
\hline Mainland & 61.6 & 66.1 & 38.4 & 33.9 \\
\hline Zanzibar & 73.5 & 85.9 & 26.5 & 14.1 \\
\hline Urban & 85.1 & 91.7 & 14.9 & 8.3 \\
\hline Rural & 53.6 & 57.6 & 46.4 & 42.4 \\
\hline National & 62.0 & 67.0 & 38.0 & 33.0 \\
\hline
\end{tabular}

Notes: Read the first column of data as "Percent of females ages 15-19 who have access to at least one of four media sources (i.e., reads newspaper/magazine, listens to radio, watches television at least once per week, respectively, or individual has mobile phone," using 2011-12 THMIS. Figures in highlighted cells are based on 25-50 unweighted cases. 


\section{GEOGRAPHIC HOTSPOTS}

Based on the results of the data analysis, we identified regions which are "hotspots", that is, geographic areas particularly unfavorable in terms of HIV vulnerability and risk for either boys or girls when compared to the national mean. Specifically, we identified nine variables which can influence HIV risk and vulnerability, as listed in the text box. Regions were identified as extreme hotspots if three of the key variables were exceptionally unfavorable compared with national means, and while they were identified as moderate hotspots if two of the key variables were exceptionally unfavorable compared with national means.

Extreme hotspots for girls are highlighted in Figure 6. These areas merit special consideration and programmatic interventions:

Dar es Salaam: Girls ages 10-14 residing in Dar have among the highest rates of being out of school and not residing with either parent (10\%). Here girls ages 15-19 have the highest estimated national HIV prevalence for

The following key variables were considered in the process of categorizing regional hotspot:

- School attendance (ages 10-14)

- School attendance and parental residence

- Early childbearing (girls only)

- Early marriage (girls only)

- Partner age differences (greater than 10 year age difference) (girls only)

- Sexual violence (girls only, because no regional estimates for boys)

- $\quad$ HIV prevention knowledge

- Comprehensive HIV knowledge

- HIV prevalence that age group (4\%). Females ages $20-24$ have extremely high levels of partnering with men more than 10 years older than themselves (25\%).

Tabora: In Tabora girls ages 10-14 have one of the highest rates of not attending school (30\%), as well as being out of school and not residing with either parent (8\%); 1 in 8 females ages 20-24 was married before the age of 15 years.

Morogoro: In Morogoro one-quarter of girls ages 10-14 were not attending school; $11 \%$ of women ages $20-24$ were married before the age of 15 years; and $13 \%$ of females ages $20-24$ gave birth before the age of 15 years.

Mara: In Mara more than 1 in 5 girls ages 15-19 has experienced sexual violence; $12 \%$ of females ages 20-24 were married before the age of 15; and more than one in four 20-24 year old females has a sexual partner 10 years older than herself.

Simiyu: In Simiyu, girls have extremely low levels of HIV knowledge and are partners with much older men. Only 30\% of females ages 15-19 know the two basic HIV prevention methods (that is, limiting sexual partners to one and using a condom) and only $13 \%$ have comprehensive HIV/ AIDS knowledge. One-quarter of females ages 20-24 reported having a partner more than 10 years their senior.

Figure 7 illustrates geographic areas proving to be moderate hotspots for girls, i.e., those for which two key outcomes are exceptionally unfavorable compared with national means, as follows:

Kagera: Both school attendance and sexual violence are problematic for girls in Kagera: $22 \%$ of girls ages $10-14$ years were not attending school the year of survey; and $21 \%$ of females ages $15-19$ had experienced sexual violence.

Mbeya: Low school attendance and high rates of sexual violence are issues for girls in Mbeya. Here $22 \%$ of girls ages $10-14$ were not attending school the year of the survey, and $21 \%$ of females ages 15-19 had experienced sexual violence. 
Kigoma: Girls in Kigoma experience low school attendance and high levels of sexual violence: $22 \%$ of girls ages 10-14 were not attending school the year of the survey, and $26 \%$ of females ages 15 19 had experienced sexual violence.

Arusha: Girls in Arusha experience high rates of social marginalization and isolation. 10\% of girls ages 10-14 are not in school and not living with either parent. This is combined with high early pregnancy rates: $13 \%$ of females ages 20-24 had given birth before the age of 15 .

Kaskazini Unguja: HIV knowledge is extremely low among females in Kaskazini Unguja: only $44 \%$ of females ages 15-19 know of the two most common methods (that is, limiting sexual partners to one and consistent condom use). Comprehensive HIV knowledge is also extremely poor there at only $16 \%$ of females ages $15-19$.

Lindi: Lindi is characterized by high rates of child marriage and early pregnancy: among females ages $20-24,13 \%$ were married and $15 \%$ gave birth before the age 15 .

Iringa and Njombe: Exposure to sexual violence and HIV are high: 24\% of females ages 15-19 had experienced sexual violence, while HIV prevalence among females ages $20-24$ is estimated at $12 \%$ in Iringa and $16 \%$ in Njombe.

Ruvuma: In Ruvuma girls face high rates of sexual violence and limited access to information. Here $21 \%$ of females ages 15-19 had experienced sexual violence, and $56 \%$ of females ages $15-19$ had no exposure to radio, TV, newspaper, or a phone.

Among boys, there were no geographic areas that were extreme hotspots, likely because four of the key variable could be measured for girls only. There were, however, several moderate hotspots for boys, which are illustrated in Figure 8 and include the following:

Lindi: Young boys in Lindi face high rates of school dropout and social exclusion: $22 \%$ of boys ages 10-14 had not attended school the year of the survey; and 9\% were neither in school nor living with any parent.

Kagera: In Kagera boys face the dual threats of early school leaving and high rates of HIV: $22 \%$ of boys ages 10-14 had not attended school the year of the survey; the HIV prevalence rate among males 20-24 in Kagera is estimated at 7\%.

Dodoma: Boys in Dodoma are socially marginalized and face high exposure to HIV: $22 \%$ of boys ages 10-14 had not attended school the year of the survey; the HIV prevalence among males 15-19 was estimated at $5 \%$.

Kaskazini Pemba: HIV knowledge is low among young males here. Among males ages 15-19, knowledge of the two most common HIV prevention methods was only at $35 \%$, while comprehensive HIV knowledge stood at only $22 \%$. 


\section{FEMALE HOTSPOTS (EXTREME)}

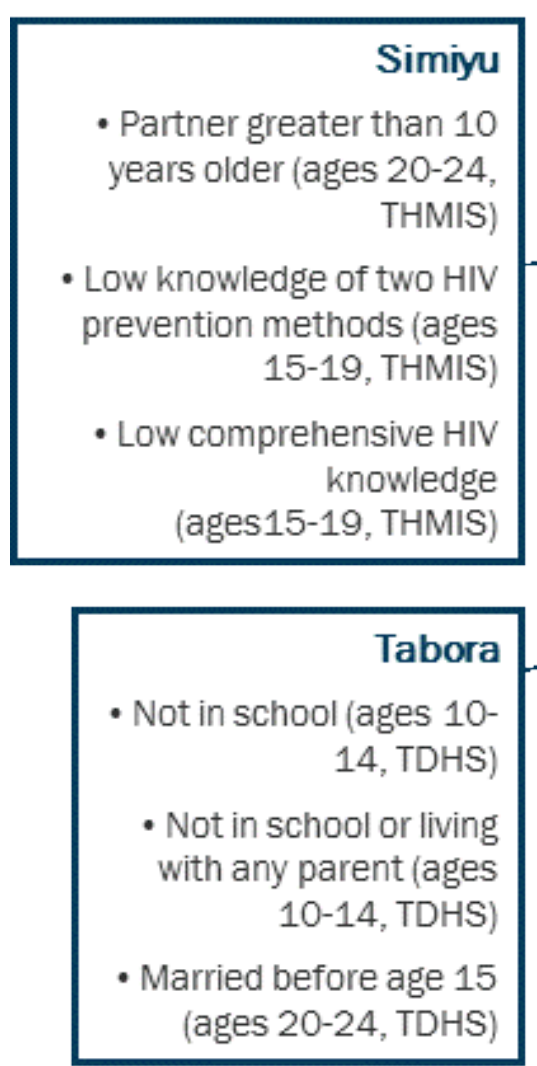

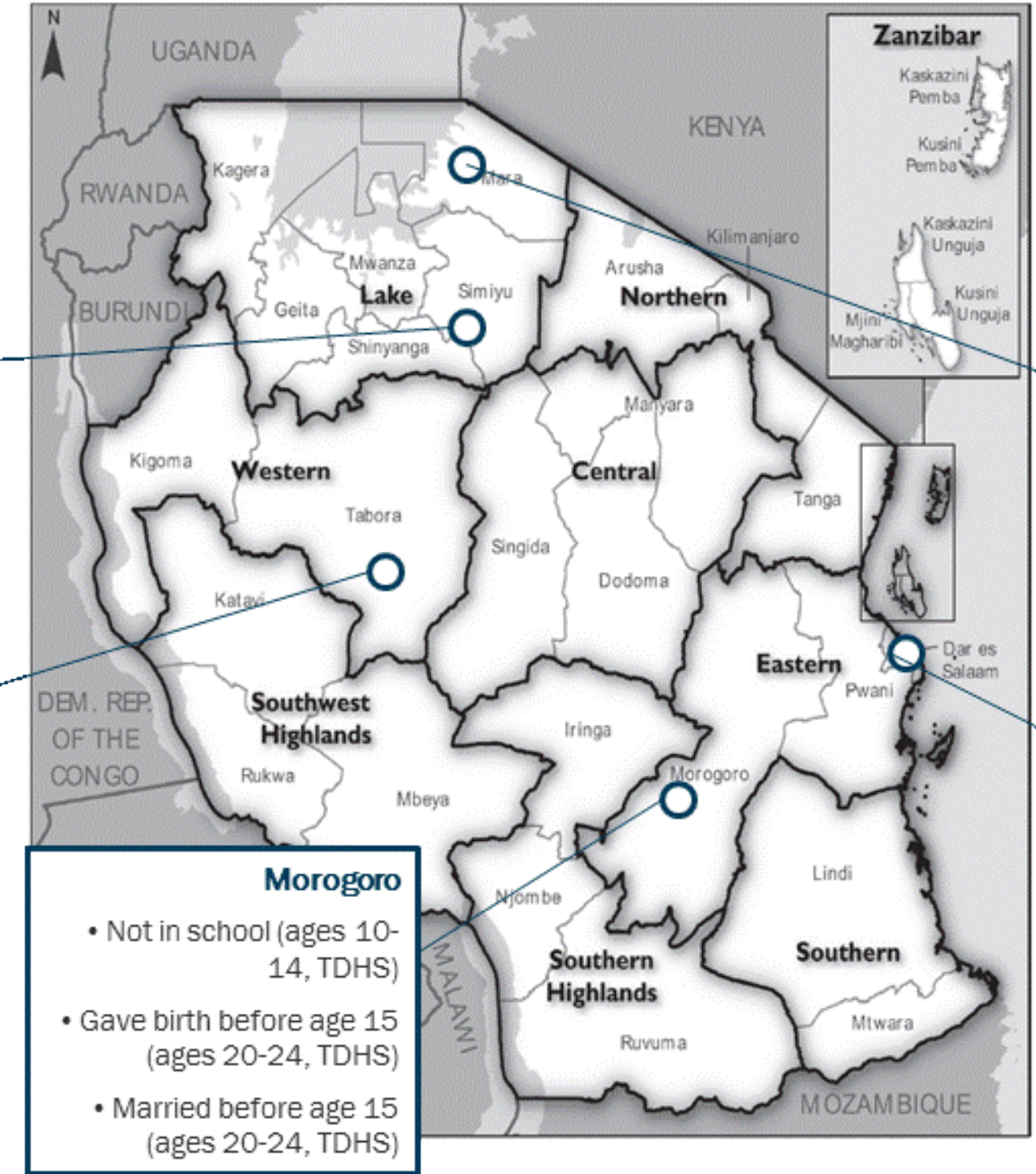

Figure 6. Map of "extreme hotspots" for girls in Tanzania, i.e., regions which had exceptionally unfavorable results for three or more of nine variables which can influence HIV risk and vulnerability.

Base map is adapted from: TACAIDS et al. 2013. HIV/AIDS and Malaria Indicator Survey 2011-12. Dar es Salaam: Tanzania Commission for AIDS (TACAIDS), Zanzibar AIDS

Commission, NBS, Office of the Chief Government Statistician, and ICF International.

- Ever experienced sexual violence (ages 15-19, TDHS)

- Married before age 15 (ages 20-24, TDHS)

- Partner greater than 10 years older (ages 20-24,

THMIS) with any parent (ages 10-14, TDHS

- Partner greater than 10 years older (ages 20-24, THMIS)

- High HIV prevalence (ages 15-19, THMIS) 


\section{FEMALE HOTSPOTS (MODERATE)}
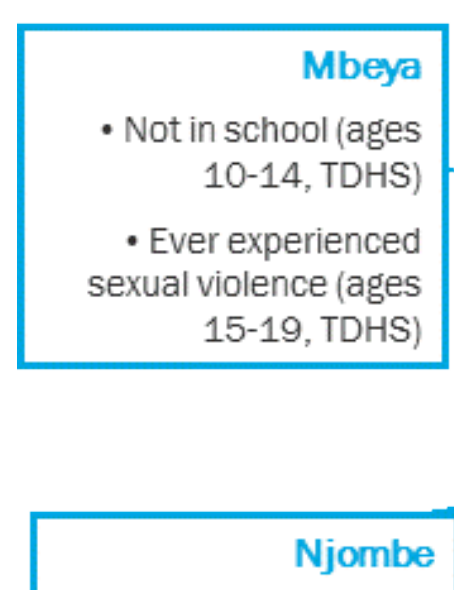

- Ever experienced sexual violence (ages 15-19, TDHS)

- High HIV prevalence (ages 20-24, TDHS)

\section{Arusha}

- Not in school or living with any parent (ages 1014, TDHS)

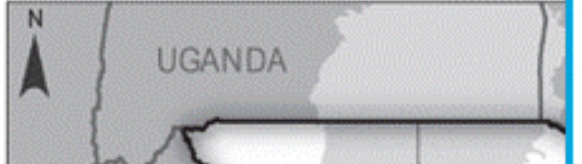

- Gave birth before age 15 (ages 20-24, TDHS)

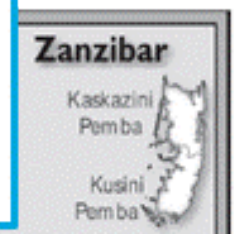

$$
\begin{array}{r}
\text { Kaskazini Unguja } \\
\text { - Low knowledge of two } \\
\text { HIV prevention } \\
\text { methods (ages 15-19, } \\
\text { TDHS) } \\
\text { Low comprehensive } \\
\text { HIV knowledge } \\
\text { (ages 15-19, THMIS) }
\end{array}
$$

Iring

Ever experienced sexual violence (ages 15-19, TDHS)

- High HIV prevalence

(ages 20-24, TDHS)

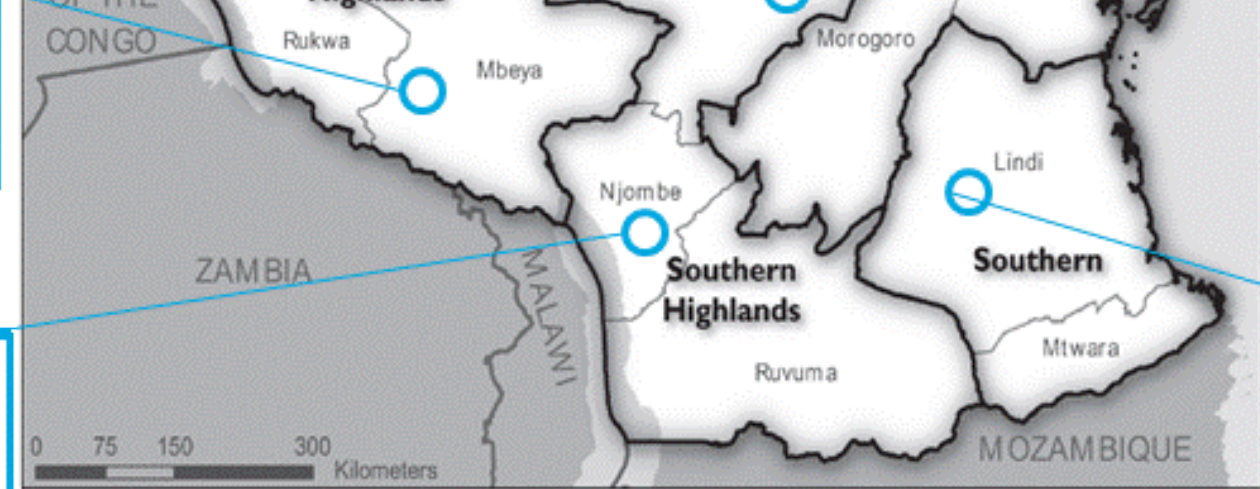

Figure 7. Map of "moderate hotspots" for girls in Tanzania, i.e., regions which had exceptionally unfavorable results for two of nine variables which can influence HIV risk and vulnerability.

Base map is adapted from: TACAIDS et al. 2013. HIV/AIDS and Malaria Indicator Survey 2011-12. Dar es Salaam: Tanzania

Commission for AIDS (TACAIDS), Zanzibar AIDS Commission, NBS, Office of the Chief Government Statistician, and ICF International. 


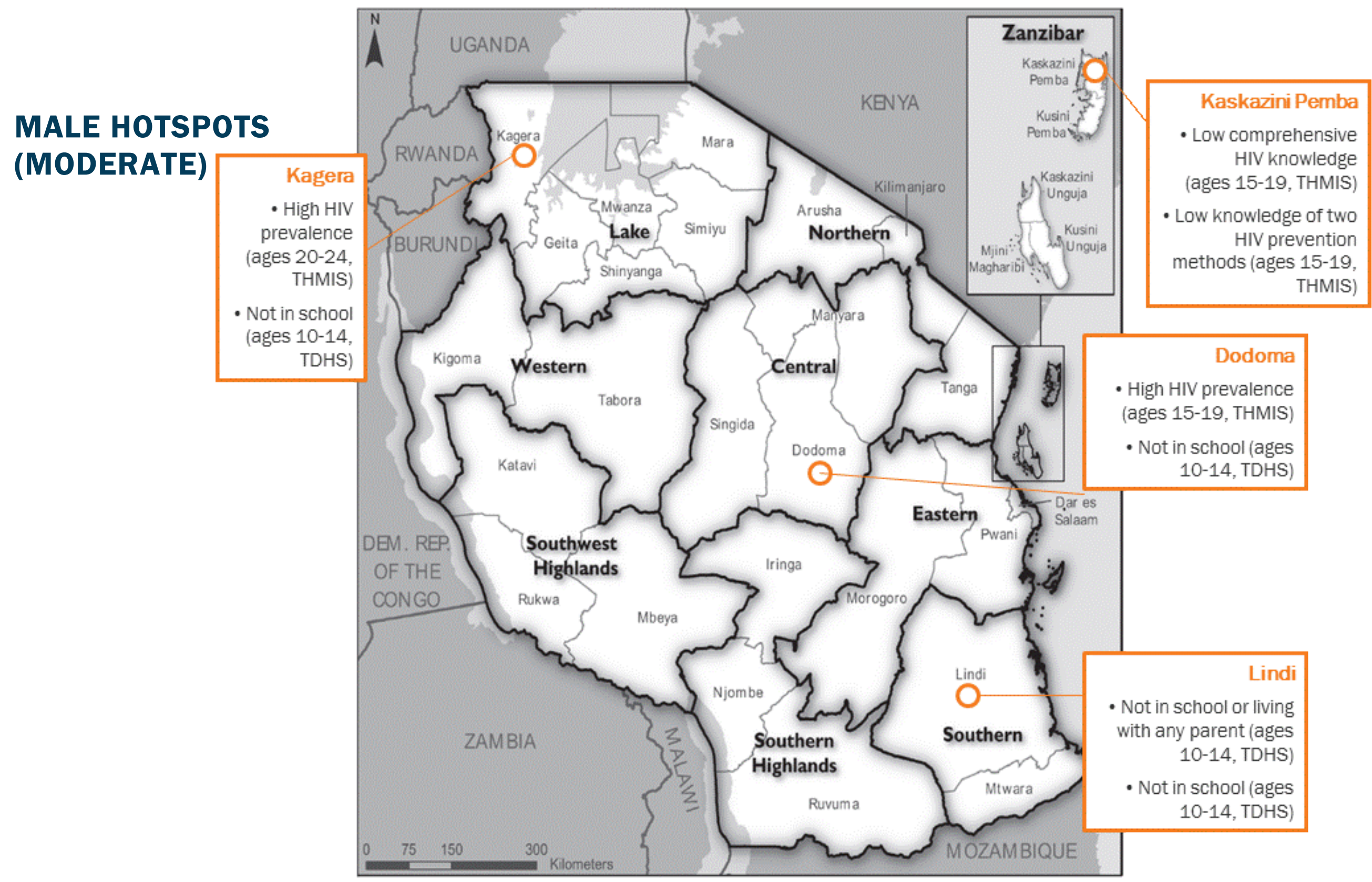

Figure 8. Map of "moderate hotspots" for boys in Tanzania, i.e., regions which had exceptionally unfavorable results for two of five variables which can influence HIV risk and vulnerability. 


\section{POLICY, PROGRAMMATIC AND RESEARCH RECOMMENDATIONS}

\section{A. Policy Recommendations:}

1. Create an overarching Child Policy rooted in an ecological approach (individual, family, community, society) which addresses different age groups, and outlines clearly defined roles and responsibilities for ministries, departments, agencies, and others responsible for child well-being.

2. Establish a Child Policy Unit in a responsible Ministry with the requisite human and financial resources to fulfill the mandate of the new Child Policy.

3. Identify comprehensive, quality education and child protection as the highest priority within the national budget and national plans, as well as within regional and Local Government Authority (LGA) plans and budgets.

4. Increase the lawful age of marriage to 18 , and address marital rape, by aligning conflicting laws, e.g., in accordance with the Mainland Law of the Child Act (2009) and the Zanzibar Children's Act (2011).

5. Establish and ensure that education is free through Form 4 in both the Mainland and Zanzibar.

6. Require a best practice, evidence-based comprehensive sexuality education (CSE) curriculum be taught within the broader school curriculum, including systematic monitoring of quality and coverage of teaching, and annual evaluation within national examinations.

7. Harmonize the Child Labour Policy with other existing policies and specify a job creation scheme within it.

8. Reduce the age of HIV testing and counselling $(\mathrm{HTC})$ without parent/guardian consent from 18 to 12 years old.

\section{B. Programmatic Recommendations - Child Protection and Economic Livelihoods:}

9. Train government authorities from regional to LGA level in relevant regulations related to children's rights, e.g., the Law of the Child Act and the Sexual Offence Special Provision Act of 1998.

10. Enforce implementation of the Sexual Offence Special Provision Act across sectors (e.g., justice, police, social work, health, education) to address issues of violence and abuse of adolescents.

11. Customize and contextualize child protection interventions to the particular needs and norms of different regions.

12. Expand parent/caregiving programmes to target parents/guardians, elderly, and young mothers and fathers (including urban, rural, married, un-married) to reduce family vulnerabilities to violence and HIV.

13. Scale up best practices in securing economic livelihoods for adolescents and young people, and prioritize young women (ages 18-24) during their transition to adulthood.

\section{Programmatic Recommendations - Education, including Comprehensive Sexuality Education:}

14. Continue scaling up conditional cash transfer programmes to keep children in school and facilitate their re-entry if they have dropped out.

15. Mobilize communities to promote sustainable, community-driven school meal programmes.

16. Require higher levels of qualifications to enter teacher training colleges, and improve the quality of teacher training college coursework.

17. Make the education system more skills-based and oriented towards real, relevant life situations.

18. Develop and disseminate guidelines to facilitate re-entry to school after dropout, marriage, or pregnancy (as per Education Training Policy).

19. Develop and disseminate guidelines and circulars for school re-entry programmes (e.g., complementary basic education in Tanzania (COBET), integrated post primary education (IPPE)) to establish clear criteria for selection and to address cost implications.

20. Sensitize communities about the economic and health benefits of education and the risks of child marriage and early pregnancy. 
21. Implement intensive campaigns to raise awareness of and create commitment to adolescent CSE amongst parents, teachers, community, and government authorities, from LGA to national level.

22. Widely disseminate CSE guidelines to schools (primary, secondary, tertiary) and implement largescale pre-service and in-service training courses to orient teachers to deliver CSE curricula.

23. Deliver extracurricular CSE to transform gender norms and reduce adolescents' vulnerabilities to violence and HIV.

24. Reach out-of-school adolescents and youth with CSE interventions.

25. Revive adult education programmes to reduce illiteracy among women in their transition to adulthood especially in rural areas.

\section{Programmatic Recommendations - Health Care:}

26. Disseminate HTC guidelines to clarify that mature minors (i.e., any person below 18 years who is married, pregnant, sexually active, or otherwise believed to be at risk for HIV infection) can be tested without parental/guardian consent.

27. Revise pre-service and in-service curricula for clinical training institutions to include CSE, youthfriendly services, and psychosocial support to HIV-positive adolescents (e.g., disclosure).

28. Train professional, non-medical HTC counsellors to perform HIV testing as part of task-sharing.

29. Increase access to friendly HIV and sexual and reproductive health (including contraception, condoms and post-violence services) for adolescents and other young people.

30. Disseminate the National Policy Guidelines for Reproductive and Child Health Services (2005), which allows for family planning and other sexual reproductive health services for adolescents without parental or partner consent.

31. Disseminate available adolescent-friendly SRH education and service guidelines for health workers.

32. Work with public and private media organizations to develop and disseminate appropriate and accurate information on CSE and youth-friendly services to reach adolescents and other youth through mobile technology, social media, radio and television.

33. Increase access to public and socially marketed condoms for sexually active adolescents and other youth, especially in rural areas, and address underlying barriers to condom use.

\section{E. Research and Monitoring and Evaluation Recommendations:}

34. Embed more robust age-disaggregated analyses in existing national surveys (e.g., DHS, THMIS) for adolescents and young adults (10-14, 15-19, 20-24), with adequate sample sizes to track results by region (including but not limited to violence and HIV prevalence among males and females).

35. Accommodate age disaggregation in routine reporting of health service statistics to track service uptake of adolescents and young adults (10-14, 15-19, 20-24) in care and treatment centre databases and the health management information system.

36. Systematically monitor the impact of social protection programmes on school attendance, risk behaviours and child marriage among adolescent and young adult beneficiaries, by sex.

37. Systematically monitor and evaluate both the quality and the coverage of life skills, HIV/AIDS, and sexuality education in schools across the country (primary, secondary, tertiary).

38. Map cultural practices and social norms at a regional level to better develop effective, contextualized child protection interventions.

39. Conduct focused research on different types of violence and the related vulnerabilities, including possible contributing factors, e.g., poverty.

40. Investigate how adolescents access media, particularly mobile technology, to better understand media potential for research and intervention.

41. Explore effective ways to increase condom access for sexually active youth, to better inform condom promotion and distribution programmes.

42. Conduct both quantitative (e.g., retrospective analysis of clinical data) and qualitative research with HIV-positive adolescents to better understand the differences in transmission among adolescents and to better respond to the needs of both perinatally and sexually infected youth.

43. Conduct quantitative and qualitative research to better understand and meet the needs of other vulnerable children, including those identified through household surveys (e.g., out-of-school children who do not live with a parent), and those who may not be reached or identified in such surveys (e.g., homeless children; key populations; migrant labourers; boarding school students). 


\section{REFERENCES}

Agnew, Christopher R., and Timothy J. Loving. 1998. The role of social desirability in self-reported condom use attitudes and intentions. AIDS and Behaviour 2(3):229-39.

Andersson, Neil, Anne Cockcroft, and Bev Shea. 2008. Gender-based violence and HIV: Relevance for HIV prevention in hyperendemic countries of southern Africa. AIDS 22 (Supplement 4):S73-S86.

Arriola, K. R., T. Louden, M. A. Doldren, and R. M. Fortenberry. 2005. A metaanalysis of the relationship of child sexual abuse to HIV risk behaviour among women. Child Abuse and Neglect 29:725-46.

Beguy, Donatien, Caroline W. Kabiru, Evangeline N. Nderu, and Moses W. Ngware. 2009. Inconsistencies in self-reporting of sexual activity among young people in Nairobi, Kenya. Journal of Adolescent Health 45:595-601.

Bertrand, Jane T., and Rebecca Anhang. 2006. The effectiveness of mass media in changing HIV/AIDS related behaviour among young people in developing countries. In Preventing HIV/AIDS in young people: A systematic review of the evidence from developing countries. World Health Organization Technical Report Series 938, ed. David A. Ross, Bruce Dick, and Jane Ferguson, 205-41. Geneva: WHO.

Bogale, G. W., H. Boer, and E. R. and Seydel. 2010. Condom use among low-literate, rural females in Ethiopia: The role of vulnerability to HIV infection, condom attitude, and self-efficacy. AIDS Care 22(7):851-7.

Boileau C., B. Vissandjee, V. K. Nguyen, S. Rashed, M. Sylla, and M. V. Zunzunegui. 2008. Gender dynamics and sexual norms among youth in Mali in the context of HIV/AIDS prevention. African Journal of Reproductive Health 12(3):173-84.

Caldwell, John C., Pat Caldwell, and Pat Quiggin. 1989. The social context of AIDS in sub-Saharan Africa. Population and Development Review 15(2):185-234.

Caldwell, John C., Pat Caldwell, Bruce K. Caldwell, and Indrani Pieris. 1998. The construction of adolescence in a changing world: Implications for sexuality, reproduction, and marriage. Studies in Family Planning 29(2):137-53.

Campbell, J. C., M. L. Baty, R. M. Ghandour, J. K. Stockman, L. Francisco, and J. Wagman. 2008. The intersection of intimate partner violence against women and HIV/AIDS: A review. International Journal of Injury Control and Safety Promotion 15: 221-31.

Catania, Joseph A., David R. Gibson, Dale D. Chitwood, and Thomas J. Coates. 1990. Methodological problems in AIDS behavioural research: Influences on measurement error and participation bias in studies of sexual behaviour. Psychological Bulletin 108(3):339-62.

Catania, Joseph A., Heather Turner, Robert C. Pierce, Eve Golden, Carol Stocking, Diane Binson, and Karen Mast. 1993. Response bias in surveys of AIDS related sexual behaviour. In Methodological issues in AIDS behavioural research, ed. D. G. Ostrow and R. C. Kessler, 133-62. New York: Plenum Press.

Clark, Shelley, Judith Bruce, and Annie Dude. 2006. Protecting young women from HIV/AIDS: The case against child and adolescent marriage. International Family Planning Perspectives 32(2):79-88.

Cowan, Frances M., Lisa F. Langhaug, George P. Mashungupa, Tellington Nyamurera, John Hargrove, Shabbar Jaffar, Rosanna W. Peeling et al. 2002. School based HIV prevention in Zimbabwe: Feasibility and acceptability of evaluation trials using biological outcomes. AIDS 16:1673-8.

Devine, Owen J., and Sevgi O. Aral. 2004. The impact of inaccurate reporting of condom use and imperfect diagnosis of sexually transmitted disease infection in studies of condom effectiveness. Sexually Transmitted Diseases 31(10):588-95.

Doyle, Aoife M., Sue Napierala Mavedzenge, Mary L. Plummer, and David A. Ross. 2012. The sexual behaviour of adolescents in sub-Saharan Africa: Patterns and trends from national surveys. Tropical Medicine and International Health 17(7): 796-807.

Dunkle, K., R. Jewkes, H. Brown, G. Gray, J. Mcintyre, and S. Harlow. 2004. Transactional sex among women in Soweto, South Africa: Prevalence, risk factors and association with HIV. Social Science and Medicine 59:1581-92.

Fenton, K. A., A. M. Johnson, S. McManus, and B. Erens. 2001. Measuring sexual behaviour: Methodological challenges in survey research. Sexually Transmitted Infections 77:84-92.

Gallant, Melanie, and Eleanor Maticka-Tyndale. 2004. School-based HIV prevention programmes for African youth. Social Science and Medicine 58(7):1337-51. 
Gregson, Simon, Constance A. Nyamukapa, Geoffrey P. Garnett, Peter R. Mason, Tom Zhuwau, Michel Caraël, Stephen K. Chandiwana, and Roy M. Anderson. 2002. Sexual mixing patterns and sexdifferentials in teenage exposure to HIV infection in rural Zimbabwe. Lancet 359:1896-1903.

Gwandure, C. 2007. Sexual assault in childhood: Risk HIV and AIDS behaviours in adulthood. AIDS Care 19:1313-15.

Hallett, Timothy B., John Stover, Vinod Mishra, Peter D. Ghys, Simon Gregson, and Ties Boerma. 2010. Estimates of HIV incidence from household-based prevalence surveys. AIDS 24(1):147-52.

Hargreaves, J. R., C. P. Bonell, T. Boler, D. Boccia, I. Birdthistle, A. Fletcher, P. M. Pronyk, and J. R. Glynn. 2008. Systematic review exploring time trends in the association between education attainment and risk of HIV infection in sub-Saharan Africa. AIDS 22:403-14.

Hoffman, S., L. F. O'Sullivan, A. Harrison, C. Dolezal, and A. Monroe-Wise. 2006. HIV risk behaviours and the context of sexual coercion in young adults' sexual interactions: Results from a diary study in rural South Africa. Sexually Transmitted Diseases 33(1):52-8.

Hunter, M. 2002. The materiality of everyday sex: Thinking beyond prostitution. African Studies 61(1):99-120.

Huygens, Pierre, Ellen Kajura, Janet Seeley, and Tom Barton. 1996. Rethinking methods for the study of sexual behaviour. Social Science and Medicine 42(2):221-31.

Jewkes, R. K., K. Dunkle, M. Nduna, and N. Shai. 2010. Intimate partner violence, relationship power inequity, and incidence of HIV infection in young women in South Africa: A cohort study. Lancet 376(9734):41-8.

Johnson, David. 2008. The changing landscape of education in Africa: Quality, equality and democracy. Oxford: Symposium Books.

Jukes, Matthew, Stephanie Simmons, and Donald Bundy. 2008. Education and vulnerability: The role of schools in protecting young women and girls from HIV in southern Africa. AIDS 22(Supplement 4):S41-56.

Lawn, J., and Kerber, K. (eds). 2006. Opportunities for Africa's newborns: Practical data, policy and programmatic support for newborn care in Africa, November 2006. Cape Town, South Africa: Partnership for Maternal, Newborn and Child Health.

LeClerc-Madlala, Suzanne. 2008. Age-disparate and intergenerational sex in southern Africa: The dynamics of hypervulnerability. AIDS 22(Supplement 4):S17-25.

Lloyd, Cynthia B., and Paul Hewett. 2009. Educational inequalities in the midst of persistent poverty: Diversity across Africa in educational outcomes. Journal of International Development 21:113751.

Luke, Nancy. 2003. Age and economic asymmetries in the sexual relationships of adolescent girls in sub-Saharan Africa. Studies in Family Planning 34(2):67-86.

Maticka-Tyndale, Eleanor, and Collins Kyeremeh. 2010. The trouble with condoms: Norms and meanings of sexuality and condom use among school-going youth in Kenya. International Journal of Sexual Health 22:234-47.

Mavedzenge, Sue M. Napierala, Aoife M. Doyle, and David A. Ross. 2011. HIV prevention in young people in sub-Saharan Africa: A systematic review. Journal of Adolescent Health 49(6):568-86.

Mensch, Barbara S., Paul C. Hewett, and Annabel S. Erulkar. 2003. The reporting of sensitive behaviour by adolescents: A methodological experiment in Kenya. Demography 40(2):247-68.

Mills, Edward J., Jean B. Nachega, David R. Bangsberg, Sonal Singh, Beth Rachlis, Ping Wu, Kumanan Wilson, lain Buchan, Christopher J. Gill, and Curtis Cooper. 2006. Adherence to HAART: A systematic review of developed and developing nation patient-reported barriers and facilitators. PLoS Medicine 3(11):2039-64.

NBS et al. 2011. Tanzania Demographic and Health Survey 2010. Dar es Salaam: National Bureau of Statistics.

Ngom, P., M. A. Magadi, and T. Owuor. 2003. Parental Presence and Adolescent Reproductive Health among the Nairobi Urban Poor. Journal of Adolescent Health 33(5): 369-77.

Nnko, Soori, and Robert Pool. 1997. Sexual discourse in the context of AIDS: Dominant themes on adolescent sexuality among primary school pupils in Magu district, Tanzania. Health Transition Review 7(Supplement 3):85-90.

Ostermann, Jan, Elizabeth A. Reddy, Meghan M. Shorter, Charles Muiruri, Antipas Mtalo, Dafrosa K. Itemba, Bernard Njau, John A. Bartlett, John A. Crump, and Nathan M. Thielman. 2011. Who tests, who doesn't, and why? Uptake of mobile HIV counseling and testing in the Kilimanjaro Region of Tanzania. PLoS ONE 6(1):e16488. 
Panos Institute. 2003. Beyond victims and villains: Addressing sexual violence in the education sector. PANOS Report No. 47. London: Panos.

Pettifor, Audrey E., Ariane van der Straten, Megan S. Dunbar, Stephen C. Shiboski, and Nancy S. Padian. 2004. Early age of first sex: A risk factor for HIV infection among women in Zimbabwe. AIDS 18:1435-42.

Plummer, Mary Louisa, and Daniel Wight. 2011. Young people's lives and sexual relationships in rural Africa: Findings from a large qualitative study in Tanzania. Lanham, Maryland: Lexington Books.

Plummer, Mary Louisa. 2012. Promoting abstinence, being faithful, and condom use with young Africans: Qualitative findings from an intervention trial in rural Tanzania. Lanham, Maryland: Lexington Books.

Population Council. 2004. Adolescent data guide, Tanzania. New York: Population Council.

Silberschmidt, Margrethe, and Vibeke Rasch. 2001. Adolescent girls, illegal abortions and "sugar daddies" in Dar es Salaam: Vulnerable victims and active social agents. Social Science and Medicine 52:1815-26.

TACAIDS et al. 2013. HIV/AIDS and Malaria Indicator Survey 2011-12. Dar es Salaam: Tanzania Commission for AIDS (TACAIDS), Zanzibar AIDS Commission, NBS, Office of the Chief Government Statistician, and ICF International.

Tawfik, L., and S. C. Watkins. 2007. Sex in Geneva, sex in Lilongwe, and sex in Balaka. Social Science and Medicine 64:1090-101.

Turner, Abigail Norris, Alana E. De Kock, Amy Meehan-Ritter, Kelly Blanchard, Mohlatlego H. Sebola, Anwar A. Hoosen, Nicol Coetzee, and Charlotte Ellertson. 2009. Many vaginal microbicide trial participants acknowledged they had misreported sensitive sexual behaviour in face-to-face interviews. Journal of Clinical Epidemiology 62(7):759-65.

UN CRC. 2003. General Comment No. 4, Adolescent health and development in the context of the Convention on the Rights of the Child. UN Document CRC/GC/2003/4.

UN Population Division. 2014. World urbanization prospects: The 2014 revision, highlights (ST/ESA/SER.A/352).

UNICEF et al. 2011. Violence against children in Tanzania: Findings from a national survey 2009. Dar es Salaam: Multi Sector Task Force on Violence Against Children.

UNICEF. 2011. Adolescence in Tanzania. Dar es Salaam, Tanzania: UNICEF.

UNICEF. 2012. Cities and children: The challenge of urbanisation in Tanzania. Dar es Salaam, Tanzania: UNICEF.

Wamoyi, Joyce, Angela Fenwick, Mark Urassa, Basia Zaba, and William Stones. 2010. 'Women's bodies are shops': Beliefs about transactional sex and implications for understanding gender power and HIV prevention in Tanzania. Archives of Sexual Behaviour DOI 10.1007/s10508-0109646-8.

Wamoyi, Joyce, Daniel Wight, and Pieter Remes. 2015. The structural influence of family and parenting on young people's sexual and reproductive health in rural northern Tanzania. Culture, Health and Sexuality DOI: 10.1080/13691058.2014.992044.

West, P., H. Sweeting, and A. Leyland. 2004. School effects of pupils' health behaviours: Evidence in support of the health promoting school. Research Papers in Education 19(3):261-91.

WHO. 2003. Creating an environment for emotional and social well-being: An important responsibility of a Health-Promoting and Child Friendly School. Geneva: WHO.

Williamson, Lisa M., Alison Parkes, Daniel Wight, Mark Petticrew, and Graham J. Hart. 2009. Limits to modern contraceptive use among women in developing countries: A systematic review of qualitative research. Reproductive Health 6:3.

Wood, K., F. Maforah, and R. Jewkes. 1998. 'He forced me to love him': Putting violence on the adolescent sexual health agenda. Social Science and Medicine 47: 233-42.

Wood, K., H. Lambert, and R. Jewkes. 2007. 'Showing roughness in a beautiful way': Talk about love, coercion, and rape in South African youth sexual culture. Medical Anthropology Quarterly 21:277300.

World Bank. 2014. Tanzania economic update: Who wants a job? The magnetic power of cities, June 2014. The World Bank Poverty Reduction and Economic Management Unit Africa Region. 


\section{ANNEXES}

\begin{tabular}{|c|c|c|c|c|}
\hline \multicolumn{5}{|c|}{$\begin{array}{l}\text { Annex Table 1B: Mainland-Zanzibar Residence and Population Distribution, } \\
\text { Percent }\end{array}$} \\
\hline & \multicolumn{2}{|c|}{ DHS } & \multicolumn{2}{|c|}{ THMIS } \\
\hline & Mainland & Zanzibar & Mainland & Zanzibar \\
\hline \multicolumn{5}{|c|}{ Girls (\% within sex) } \\
\hline Age 10-14 & 97.2 & 2.8 & 96.8 & 3.2 \\
\hline $15-19$ & 96.3 & 3.7 & 96.2 & 3.8 \\
\hline $15-17$ & 96.5 & 3.6 & 96.0 & 4.0 \\
\hline $18-19$ & 96.0 & 4.1 & 96.4 & 3.7 \\
\hline $20-24$ & 96.5 & 3.6 & 95.6 & 4.4 \\
\hline \multicolumn{5}{|c|}{ Boys (\% within sex) } \\
\hline Age 10-14 & 97.0 & 3.1 & 97.1 & 2.9 \\
\hline $15-19$ & 96.7 & 3.3 & 96.2 & 3.8 \\
\hline $15-17$ & 96.8 & 3.3 & 96.4 & 3.6 \\
\hline $18-19$ & 96.6 & 3.4 & 96.0 & 4.0 \\
\hline $20-24$ & 96.5 & 3.5 & 95.9 & 4.1 \\
\hline
\end{tabular}




\begin{tabular}{|c|c|c|c|c|c|c|c|c|}
\hline \multirow[b]{3}{*}{ Region } & rental Re & nce in & usehold & Male & d Female & ses, 1 & 4 , Percen & \\
\hline & \multicolumn{2}{|c|}{ Both parents in $\mathrm{HH}$} & \multicolumn{2}{|c|}{ Mother only in $\mathrm{HH}$} & \multicolumn{2}{|c|}{ Father only in $\mathrm{HH}$} & \multicolumn{2}{|c|}{$\begin{array}{c}\text { Neither parent in } \\
\mathrm{HH}\end{array}$} \\
\hline & $\begin{array}{c}\text { Females } \\
\text { (\% within } \\
\text { sex for } \\
\text { age) }\end{array}$ & $\begin{array}{l}\text { Males } \\
(\% \\
\text { within } \\
\text { sex for } \\
\text { age) }\end{array}$ & $\begin{array}{c}\text { Females } \\
\text { (\% within } \\
\text { sex for } \\
\text { age) }\end{array}$ & $\begin{array}{c}\text { Males } \\
(\% \\
\text { within } \\
\text { sex for } \\
\text { age) }\end{array}$ & $\begin{array}{c}\text { Females } \\
\text { (\% within } \\
\text { sex for } \\
\text { age) }\end{array}$ & $\begin{array}{l}\text { Males } \\
(\% \\
\text { within } \\
\text { sex for } \\
\text { age) }\end{array}$ & $\begin{array}{c}\text { Females } \\
\text { (\% within } \\
\text { sex for } \\
\text { age) }\end{array}$ & $\begin{array}{c}\text { Males } \\
(\% \\
\text { within } \\
\text { sex for } \\
\text { age) }\end{array}$ \\
\hline \multicolumn{9}{|l|}{ Mainland } \\
\hline Arusha & 50 & 60.8 & 17.8 & 15.2 & 7.6 & 8.2 & 24.6 & 15.8 \\
\hline Dar es Salaam & 36.7 & 49.6 & 19.8 & 20.2 & 6.7 & 7.4 & 36.8 & 22.8 \\
\hline Dodoma & 44.8 & 57 & 31.4 & 22.3 & 6.1 & 9.2 & 17.7 & 11.4 \\
\hline Iringa & 40.7 & 49.2 & 28.3 & 22 & 7.7 & 8.2 & 23.3 & 20.7 \\
\hline Kagera & 45.8 & 51.8 & 15.1 & 15.3 & 11.4 & 14.2 & 27.7 & 18.7 \\
\hline Kigoma & 57.8 & 62.7 & 19.5 & 24.2 & 3.9 & 4 & 18.8 & 9.1 \\
\hline Kilimanjaro & 48.2 & 45.9 & 14.3 & 20 & 5.2 & 7.3 & 32.3 & 26.8 \\
\hline Lindi & 44.5 & 32.9 & 27.3 & 32.7 & 4 & 10.6 & 24.2 & 23.8 \\
\hline Manyara & 69.4 & 73.3 & 8.5 & 5.3 & 4.1 & 7.8 & 17.9 & 13.6 \\
\hline Mara & 51.8 & 53.6 & 21.6 & 18.7 & 7.1 & 4.9 & 19.5 & 22.7 \\
\hline Mbeya & 52.1 & 51.2 & 15.8 & 18.7 & 8.6 & 9.3 & 23.5 & 20.7 \\
\hline Morogoro & 47.6 & 51.7 & 17.5 & 24.8 & 11.9 & 6.6 & 23 & 16.9 \\
\hline Mtwara & 28.6 & 41.2 & 23.1 & 20.3 & 12 & 11 & 36.3 & 27.5 \\
\hline Mwanza & 39.2 & 41.9 & 21.6 & 17.2 & 7.8 & 12.7 & 31.5 & 28.1 \\
\hline Pwani & 33.4 & 42.8 & 23 & 22.6 & 7 & 3.3 & 36.7 & 31.3 \\
\hline Rukwa & 67.4 & 62.1 & 8.4 & 10.6 & 7.6 & 10.6 & 16.6 & 16.7 \\
\hline Ruvuma & 58.3 & 52.8 & 12.4 & 16.6 & 8 & 13.4 & 21.3 & 17.3 \\
\hline Shinyanga & 53.6 & 57.6 & 15.3 & 11.9 & 11.5 & 6.1 & 19.7 & 24.4 \\
\hline Singida & 58.9 & 64 & 21.2 & 15.5 & 1.8 & 6.2 & 18.1 & 14.3 \\
\hline Tabora & 53.5 & 50.8 & 9.3 & 16.2 & 13.5 & 11.7 & 23.6 & 21.3 \\
\hline Tanga & 52.7 & 51.9 & 21 & 17.8 & 2.8 & 12.5 & 23.5 & 17.8 \\
\hline \multicolumn{9}{|l|}{ Zanzibar } \\
\hline Kaskazini Unguja & 47.6 & 66.2 & 15 & 10.4 & 5.2 & 4.3 & 32.2 & 19.1 \\
\hline Kusini Unguja & 39.5 & 50.4 & 16.2 & 19.3 & 5.5 & 5.8 & 38.7 & 24.5 \\
\hline Mjini Magharibi & 50.7 & 62.4 & 11.7 & 16.7 & 4.3 & 6.5 & 33.3 & 14.4 \\
\hline Kaskazini Pemba & 55.8 & 71.4 & 15 & 14.1 & 0.5 & 2.4 & 28.7 & 12.1 \\
\hline Kusini Pemba & 64.1 & 69.3 & 11 & 10.5 & 5.5 & 3.2 & 19.5 & 17 \\
\hline Mainland & 48.7 & 52.6 & 18.6 & 18 & 7.9 & 9 & 24.8 & 20.3 \\
\hline Zanzibar & 52.7 & 65.1 & 13.1 & 14.2 & 4.2 & 4.6 & 30.1 & 16.1 \\
\hline Urban & 36.7 & 49.8 & 20.7 & 20 & 7.1 & 9.8 & 35.5 & 20.4 \\
\hline Rural & 52.1 & 53.8 & 17.9 & 17.4 & 8 & 8.7 & 22 & 20.2 \\
\hline National & 48.8 & 53 & 18.5 & 17.9 & 7.8 & 8.9 & 24.9 & 20.2 \\
\hline
\end{tabular}




\begin{tabular}{|c|c|c|c|c|c|c|c|c|}
\hline \multicolumn{9}{|c|}{$\begin{array}{l}\text { Annex Table 2A-2: Parental Residence in } \\
\text { 2010) }\end{array}$} \\
\hline \multirow{2}{*}{ (n) } & \multicolumn{2}{|c|}{ Both parents in $\mathrm{HH}$} & \multicolumn{2}{|c|}{ Mother only in $\mathrm{HH}$} & \multicolumn{2}{|c|}{ Father only in $\mathrm{HH}$} & \multicolumn{2}{|c|}{$\begin{array}{c}\text { Neither parent in } \\
\mathrm{HH}\end{array}$} \\
\hline & $\begin{array}{l}\text { Females } \\
\text { (\% within } \\
\text { sex for } \\
\text { age) }\end{array}$ & $\begin{array}{l}\text { Males } \\
(\% \\
\text { within } \\
\text { sex for } \\
\text { age })\end{array}$ & $\begin{array}{l}\text { Females } \\
\text { (\% within } \\
\text { sex for } \\
\text { age) }\end{array}$ & $\begin{array}{l}\text { Males } \\
(\% \\
\text { within } \\
\text { sex for } \\
\text { age })\end{array}$ & $\begin{array}{l}\text { Females } \\
\text { (\% within } \\
\text { sex for } \\
\text { age) }\end{array}$ & $\begin{array}{l}\text { Males } \\
(\% \\
\text { within } \\
\text { sex for } \\
\text { age })\end{array}$ & $\begin{array}{l}\text { Females } \\
\text { (\% within } \\
\text { sex for } \\
\text { age) }\end{array}$ & $\begin{array}{c}\text { Males } \\
(\% \\
\text { within } \\
\text { sex for } \\
\text { age })\end{array}$ \\
\hline \multicolumn{9}{|l|}{ Mainland } \\
\hline Arusha & 32.6 & 58.3 & 19.9 & 23.4 & 13.6 & 3.7 & 34 & 14.7 \\
\hline Dar es Salaam & 27.9 & 52.3 & 10.9 & 7.1 & 3.9 & 6.7 & 57.3 & 33.8 \\
\hline Dodoma & 47 & 53.4 & 16.5 & 29.1 & 9.4 & 2.4 & 27.1 & 15 \\
\hline Iringa & 39.5 & 34.8 & 22.8 & 18.7 & 1.4 & 3.3 & 36.3 & 43.2 \\
\hline Kagera & 29.6 & 36.8 & 19.8 & 28.6 & 14.5 & 4.8 & 36.1 & 29.8 \\
\hline Kigoma & 46.4 & 56 & 23.7 & 21.6 & 1.1 & 5.4 & 28.8 & 17.1 \\
\hline Kilimanjaro & 38.1 & 47.7 & 9.5 & 12.5 & 6.7 & 0 & 45.7 & 39.8 \\
\hline Lindi & 46 & 16.9 & 19 & 29.7 & 3.7 & 7.8 & 31.3 & 45.6 \\
\hline Manyara & 68.4 & 65.8 & 3 & 12.5 & 0 & 0 & 28.6 & 21.7 \\
\hline Mara & 30.3 & 32.8 & 14.5 & 29.8 & 1.4 & 11.1 & 53.7 & 26.2 \\
\hline Mbeya & 41.1 & 50.2 & 14.1 & 17.4 & 8.9 & 10 & 35.8 & 22.4 \\
\hline Morogoro & 20.2 & 45.3 & 30 & 21.3 & 5.3 & 11 & 44.5 & 22.5 \\
\hline Mtwara & 24.1 & 39 & 25.5 & 19.3 & 8.3 & 16.5 & 42 & 25.2 \\
\hline Mwanza & 39.1 & 26.8 & 13.2 & 21.6 & 8.8 & 10.3 & 38.9 & 41.2 \\
\hline Pwani & 39.5 & 40.4 & 30.6 & 18.6 & 2.3 & 12.2 & 27.6 & 28.8 \\
\hline Rukwa & 57.3 & 68.1 & 12.4 & 8.4 & 4.5 & 6 & 25.9 & 17.5 \\
\hline Ruvuma & 37.8 & 46.8 & 17.8 & 5.3 & 10 & 16.3 & 34.4 & 31.6 \\
\hline Shinyanga & 47.8 & 44.3 & 14.6 & 14.7 & 6.5 & 16.2 & 31.1 & 24.8 \\
\hline Singida & 61.2 & 50.8 & 16.7 & 11.9 & 6.1 & 7.4 & 16 & 29.9 \\
\hline Tabora & 37.5 & 46.2 & 4.7 & 13.4 & 16.2 & 15.6 & 41.6 & 24.8 \\
\hline Tanga & 29.4 & 41.3 & 20.5 & 19.2 & 1.7 & 11.2 & 48.3 & 28.3 \\
\hline \multicolumn{9}{|l|}{ Zanzibar } \\
\hline Kaskazini Unguja & 53.1 & 54.9 & 14.5 & 18 & 1.3 & 5.9 & 31.1 & 21.1 \\
\hline Kusini Unguja & 32.8 & 50.1 & 27.7 & 13.5 & 1.5 & 9.5 & 38.1 & 27 \\
\hline Mjini Magharibi & 42.6 & 48.7 & 20.2 & 15.7 & 6.3 & 11.5 & 31 & 24 \\
\hline Kaskazini Pemba & 62.2 & 69.6 & 10.9 & 15.4 & 1.5 & 3.7 & 25.3 & 11.2 \\
\hline Kusini Pemba & 51.6 & 75.2 & 18.5 & 9.7 & 7.3 & 4.5 & 22.6 & 10.6 \\
\hline Mainland & 38.5 & 44.1 & 16.5 & 18.7 & 6.9 & 8.7 & 38.2 & 28.5 \\
\hline Zanzibar & 49.6 & 59.1 & 17.5 & 14.7 & 4.2 & 7.5 & 28.6 & 18.7 \\
\hline Urban & 28.7 & 40.8 & 15.6 & 14.8 & 5.4 & 9 & 50.3 & 35.4 \\
\hline Rural & 43 & 45.8 & 16.9 & 19.7 & 7.3 & 8.6 & 32.7 & 25.9 \\
\hline National & 38.9 & 44.6 & 16.5 & 18.5 & 6.8 & 8.7 & 37.8 & 28.2 \\
\hline
\end{tabular}




\begin{tabular}{|c|c|c|c|c|c|c|c|c|}
\hline \multicolumn{9}{|c|}{$\begin{array}{l}\text { Annex Table Table 2B-1: Parental Residence in Household (HH), Males and Females Ages, 10-14, Percent } \\
\text { (THMIS 2011-2012) }\end{array}$} \\
\hline \multirow[b]{2}{*}{ Region } & \multicolumn{2}{|c|}{ Both parents in $\mathrm{HH}$} & \multicolumn{2}{|c|}{ Mother only in $\mathrm{HH}$} & \multicolumn{2}{|c|}{ Father only in $\mathrm{HH}$} & \multicolumn{2}{|c|}{ Neither parent in $\mathrm{HH}$} \\
\hline & $\begin{array}{c}\text { Females } \\
\text { (\% within } \\
\text { sex for } \\
\text { age) }\end{array}$ & $\begin{array}{l}\text { Males (\% } \\
\text { within } \\
\text { sex for } \\
\text { age) }\end{array}$ & $\begin{array}{c}\text { Females } \\
\text { (\% within } \\
\text { sex for } \\
\text { age) }\end{array}$ & $\begin{array}{l}\text { Males (\% } \\
\text { within } \\
\text { sex for } \\
\text { age) }\end{array}$ & $\begin{array}{l}\text { Females } \\
\text { (\% within } \\
\text { sex for } \\
\text { age) }\end{array}$ & $\begin{array}{l}\text { Males (\% } \\
\text { within } \\
\text { sex for } \\
\text { age) }\end{array}$ & $\begin{array}{l}\text { Females } \\
\text { (\% within } \\
\text { sex for } \\
\text { age) }\end{array}$ & $\begin{array}{c}\text { Males (\% } \\
\text { within } \\
\text { sex for } \\
\text { age) }\end{array}$ \\
\hline \multicolumn{9}{|l|}{ Mainland } \\
\hline Arusha & 49 & 59.5 & 27.2 & 21.3 & 2.5 & 2.6 & 21.4 & 16.6 \\
\hline Dar es Salaam & 44.3 & 52 & 21.4 & 15.6 & 3.4 & 11.2 & 30.9 & 21.2 \\
\hline Dodoma & 54.4 & 51.3 & 20.1 & 15.3 & 1.3 & 5 & 24.2 & 28.5 \\
\hline Geita & 52.1 & 57 & 16.2 & 13 & 11.4 & 8 & 20.3 & 21.9 \\
\hline Iringa & 41.9 & 50.8 & 18.2 & 20.9 & 1.5 & 0.8 & 38.4 & 27.4 \\
\hline Kagera & 55.4 & 64 & 26.3 & 17.1 & 4.1 & 6.6 & 14.2 & 12.3 \\
\hline Katavi & 59.6 & 59.6 & 12 & 6 & 9.9 & 8.1 & 18.4 & 26.2 \\
\hline Kigoma & 55.4 & 54 & 22.1 & 28.9 & 1.7 & 1.8 & 20.8 & 15.3 \\
\hline Kilimanjaro & 48.4 & 52.4 & 26.5 & 17.1 & 3.7 & 6.1 & 21.4 & 24.4 \\
\hline Lindi & 45.2 & 29.5 & 21.4 & 26.9 & 6.5 & 9.7 & 26.9 & 33.9 \\
\hline Manyara & 61.3 & 68.6 & 10 & 8.9 & 2.4 & 6.2 & 26.4 & 16.2 \\
\hline Mara & 58.3 & 47.8 & 18.8 & 27.6 & 9.3 & 7.3 & 13.5 & 17.3 \\
\hline Mbeya & 61.8 & 55.5 & 10.2 & 12.6 & 7.9 & 10.4 & 20.1 & 21.5 \\
\hline Morogoro & 38.3 & 51.5 & 29.5 & 15.5 & 11.8 & 17.2 & 20.3 & 15.7 \\
\hline Mtwara & 27.8 & 29.8 & 32.1 & 26.8 & 11.6 & 12.5 & 28.6 & 31 \\
\hline Mwanza & 50.1 & 49.6 & 18 & 16.8 & 5.8 & 12.5 & 26.1 & 21.1 \\
\hline Njombe & 44.4 & 46 & 18 & 21 & 11.6 & 9.9 & 26 & 23.1 \\
\hline Pwani & 33.8 & 52.2 & 16.5 & 8.4 & 13.3 & 9.5 & 36.3 & 29.8 \\
\hline Rukwa & 72.1 & 64.5 & 13.1 & 11.1 & 0.4 & 7.8 & 14.3 & 16.6 \\
\hline Ruvuma & 49.5 & 48.2 & 20.3 & 21.4 & 8.6 & 11.5 & 21.5 & 18.9 \\
\hline Shinyanga & 47 & 43.1 & 31.1 & 19.8 & 6.2 & 12.8 & 15.7 & 24.3 \\
\hline Simiyu & 53.8 & 51.9 & 21.2 & 26.1 & 5.7 & 6.8 & 19.3 & 15.2 \\
\hline Singida & 55.2 & 61.6 & 20.1 & 9.3 & 6.4 & 7.2 & 18.2 & 21.9 \\
\hline Tabora & 51.1 & 53.9 & 15.9 & 12.4 & 12.2 & 11.8 & 20.7 & 21.9 \\
\hline Tanga & 46 & 42.1 & 16.8 & 23.9 & 7.9 & 9.6 & 29.4 & 24.4 \\
\hline \multicolumn{9}{|l|}{ Zanzibar } \\
\hline $\begin{array}{l}\text { Kaskazini } \\
\text { Unguja }\end{array}$ & 61.8 & 70.6 & 14 & 14.9 & 0.7 & 1.3 & 23.5 & 13.2 \\
\hline Kusini Unguja & 32.9 & 43.7 & 17.5 & 15.8 & 7.7 & 10.9 & 41.9 & 29.7 \\
\hline $\begin{array}{c}\text { Mjini } \\
\text { Magharibi }\end{array}$ & 49.5 & 55.2 & 24.7 & 14.6 & 3.6 & 18.6 & 22.2 & 11.7 \\
\hline $\begin{array}{l}\text { Kaskazini } \\
\text { Pemba }\end{array}$ & 64.7 & 67.7 & 10.1 & 9.8 & 5.4 & 3.3 & 19.8 & 19.2 \\
\hline Kusini Pemba & 54.8 & 66.5 & 12.8 & 12.2 & 2.5 & 4 & 29.8 & 17.3 \\
\hline Mainland & 50.7 & 51.8 & 20.1 & 18.1 & 6.7 & 8.8 & 22.5 & 21.4 \\
\hline Zanzibar & 52.8 & 60.3 & 19 & 13.5 & 3.7 & 10.9 & 24.5 & 15.3 \\
\hline Urban & 42.4 & 46.6 & 21.1 & 21.6 & 5.4 & 9.1 & 31.2 & 22.7 \\
\hline Rural & 52.9 & 53.2 & 19.8 & 17.1 & 6.9 & 8.8 & 20.4 & 20.9 \\
\hline National & 50.8 & 52 & 20.1 & 17.9 & 6.6 & 8.9 & 22.6 & 21.2 \\
\hline
\end{tabular}




\begin{tabular}{|c|c|c|c|c|c|c|c|c|}
\hline \multicolumn{9}{|c|}{$\begin{array}{l}\text { Annex Table 2B-2: Parental Residence in Household (HH), Males and Females Ages, 15-17, Percent (THMIS } \\
\text { 2011-2012) }\end{array}$} \\
\hline \multirow[b]{2}{*}{ Region } & \multicolumn{2}{|c|}{ Both parents in $\mathrm{HH}$} & \multicolumn{2}{|c|}{ Mother only in $\mathrm{HH}$} & \multicolumn{2}{|c|}{ Father only in $\mathrm{HH}$} & \multicolumn{2}{|c|}{ Neither parent in $\mathrm{HH}$} \\
\hline & Females & Males & Females & Males & Females & Males & Females & Males \\
\hline \multicolumn{9}{|l|}{ Mainland } \\
\hline Arusha & 45 & 62.9 & 11.7 & 11.8 & 2.1 & 11.2 & 41.3 & 14.1 \\
\hline Dar es Salaam & 9.8 & 42.2 & 13.3 & 10.7 & 6.5 & 8 & 70.4 & 39 \\
\hline Dodoma & * & 63.7 & * & 17 & * & 0 & * & 19.2 \\
\hline Geita & 39.6 & 44.9 & 13.7 & 11.4 & 10.7 & 9.7 & 36 & 34 \\
\hline Iringa & 39.7 & 34.2 & 27.7 & 22.2 & 2.8 & 2.4 & 29.8 & 41.1 \\
\hline Kagera & 42.9 & 43 & 22.4 & 23.4 & 4.6 & 5.6 & 30.1 & 28 \\
\hline Katavi & 45.4 & 66 & 13 & 15.6 & 8.2 & 4.4 & 33.4 & 14.1 \\
\hline Kigoma & 49.3 & 47.2 & 24.5 & 29.9 & 3.5 & 4 & 22.7 & 19 \\
\hline Kilimanjaro & 40.2 & 50.4 & 13 & 11.1 & 5.5 & 10.4 & 41.3 & 28 \\
\hline Lindi & 26.4 & 20.5 & 42.6 & 36.1 & 7.1 & 12.2 & 23.9 & 31.1 \\
\hline Manyara & 61.4 & 63.6 & 11.8 & 10.7 & 13.1 & 12.8 & 13.6 & 12.9 \\
\hline Mara & 25.7 & 40.1 & 15.8 & 14.6 & 5.6 & 11.6 & 52.9 & 33.7 \\
\hline Mbeya & 43.5 & 49.6 & 12.6 & 12.5 & 0 & 9.3 & 43.9 & 28.5 \\
\hline Morogoro & 44.9 & 36.7 & 5.9 & 27.8 & 12.6 & 25.4 & 36.5 & 10.1 \\
\hline Mtwara & 18.1 & 20.1 & 20.2 & 23.3 & 6.7 & 12.1 & 55 & 44.5 \\
\hline Mwanza & 29.2 & 36.4 & 21.7 & 15.8 & 6.3 & 9.3 & 42.8 & 38.6 \\
\hline Njombe & 40 & 23.8 & 15.6 & 29.4 & 9.6 & 16.4 & 34.8 & 30.4 \\
\hline Pwani & 22.4 & 35.2 & 25.7 & 11.4 & 5.7 & 18.3 & 46.1 & 35.1 \\
\hline Rukwa & 43.6 & 58.8 & 18.4 & 17.3 & 8.4 & 1.7 & 29.6 & 22.2 \\
\hline Ruvuma & 26.4 & 36.5 & 13.2 & 21.3 & 7.6 & 9.9 & 52.8 & 32.4 \\
\hline Shinyanga & 28.1 & 44.8 & 24.1 & 17.1 & 5.1 & 6.7 & 42.6 & 31.5 \\
\hline Simiyu & 42.1 & 52.7 & 13.4 & 17.1 & 7.5 & 10.1 & 37 & 20.1 \\
\hline Singida & 42.4 & 40.1 & 23.6 & 22.9 & 4.3 & 5.2 & 29.7 & 31.7 \\
\hline Tabora & 24.9 & 41 & 18.7 & 11.9 & 11.7 & 9.7 & 44.7 & 37.4 \\
\hline Tanga & 42.4 & 37.1 & 31.3 & 21.2 & 3.8 & 15.8 & 22.5 & 26 \\
\hline \multicolumn{9}{|l|}{ Zanzibar } \\
\hline $\begin{array}{l}\text { Kaskazini } \\
\text { Unguja }\end{array}$ & 76.1 & 53.1 & 10.6 & 19.2 & 1.4 & 1.5 & 11.9 & 26.2 \\
\hline Kusini Unguja & 44.5 & 23.6 & 2.9 & 21.5 & 6.7 & 15.4 & 46 & 39.4 \\
\hline $\begin{array}{c}\text { Mjini } \\
\text { Magharibi }\end{array}$ & 39.4 & 55.3 & 19 & 15.3 & 15.7 & 12.2 & 25.9 & 17.2 \\
\hline $\begin{array}{l}\text { Kaskazini } \\
\text { Pemba }\end{array}$ & 63.3 & 60.3 & 17 & 6.6 & 0 & 5.6 & 19.7 & 27.6 \\
\hline Kusini Pemba & 55.2 & 58.1 & 9.7 & 11.4 & 0 & 9 & 35.1 & 21.5 \\
\hline Mainland & 35.1 & 43.8 & 17.5 & 17.8 & 6.2 & 9.6 & 41.2 & 28.7 \\
\hline Zanzibar & 49.1 & 53.6 & 15.7 & 14.5 & 9.3 & 9.7 & 25.9 & 22.1 \\
\hline Urban & 24.4 & 33.6 & 18.2 & 20.2 & 4.9 & 7.2 & 52.5 & 39 \\
\hline Rural & 40.1 & 47 & 17.1 & 17.1 & 6.9 & 10.3 & 35.9 & 25.6 \\
\hline National & 35.6 & 44.2 & 17.4 & 17.7 & 6.4 & 9.6 & 40.6 & 28.5 \\
\hline
\end{tabular}




\begin{tabular}{|c|c|c|c|c|c|c|}
\hline \multirow{2}{*}{ Annex Table 3A-1: Parental Survival among $10-14$ year olds, Percent (DHS 2010) } \\
\hline \multirow{2}{*}{ Region } & \multicolumn{2}{|c|}{ Both parents alive } & \multicolumn{2}{c|}{ One parent dead } & \multicolumn{2}{c|}{ Neither parent alive } \\
\cline { 2 - 7 } & Females & Males & Females & Males & Females & Males \\
\hline Mainland & & & & & & \\
\hline Arusha & 81.1 & 86.4 & 17.9 & 13.3 & 1 & 0.3 \\
\hline Dar es Salaam & 80.8 & 75.1 & 15.9 & 22.6 & 2.1 & 2.3 \\
\hline Dodoma & 78.7 & 87.8 & 18.4 & 10 & 2.9 & 2.2 \\
\hline Iringa & 75.1 & 74 & 21.5 & 17 & 3.4 & 9 \\
\hline Kagera & 81.3 & 77.2 & 17.2 & 21.6 & 1.5 & 0.7 \\
\hline Kigoma & 87.4 & 91.4 & 9.7 & 8.6 & 2.9 & 0 \\
\hline Kilimanjaro & 82.1 & 86.5 & 15.9 & 11.4 & 2 & 2.1 \\
\hline Lindi & 88 & 90.5 & 10.6 & 8.7 & 1.3 & 0.8 \\
\hline Manyara & 92.4 & 94.1 & 6.1 & 5.5 & 1.4 & 0.4 \\
\hline Mara & 79.9 & 82.9 & 15.8 & 12.9 & 3.1 & 3.7 \\
\hline Mbeya & 85.5 & 80.6 & 8.5 & 16.9 & 6 & 2.5 \\
\hline Morogoro & 86.1 & 87 & 12.2 & 10.5 & 1.7 & 2.5 \\
\hline Mtwara & 84.4 & 87.8 & 14.8 & 12.2 & 0.7 & 0 \\
\hline Mwanza & 86.4 & 82.1 & 12.5 & 16.1 & 1.1 & 1.8 \\
\hline Pwani & 86.2 & 79.9 & 11 & 20.1 & 2.8 & 0 \\
\hline Rukwa & 87.8 & 81 & 9.9 & 15.3 & 2.4 & 3.7 \\
\hline Ruvuma & 85.6 & 85.7 & 12.2 & 11.6 & 1.6 & 2.7 \\
\hline Shinyanga & 84.6 & 86.6 & 12.7 & 12.9 & 2.7 & 0.5 \\
\hline Singida & 91.8 & 90.3 & 7 & 8.3 & 1.2 & 0.9 \\
\hline Tabora & 82.6 & 88.9 & 14.8 & 9.8 & 2.6 & 1.3 \\
\hline Tanga & 84 & 90.8 & 11.9 & 7.4 & 4.1 & 1.8 \\
\hline Zanzibar & & & & & & \\
\hline Kaskazini Unguja & 88.5 & 90.9 & 11.5 & 9.1 & 0 & 0 \\
\hline Kusini Unguja & 87.2 & 94.5 & 12.2 & 4.8 & 0 & 0 \\
\hline Mjini Magharibi & 90 & 91 & 9.3 & 7.8 & 0.7 & 1.3 \\
\hline Kaskazini Pemba & 90.3 & 92.6 & 9 & 6.9 & 0.6 & 0.5 \\
\hline Kusini Pemba & 91.3 & 93 & 8.7 & 7 & 0 & 0 \\
\hline Mainland & 84 & 84.6 & 13.4 & 13.4 & 2.5 & 1.9 \\
\hline Zanzibar & 89.8 & 92 & 9.8 & 7.4 & 0.4 & 0.6 \\
\hline Urban & 82.6 & 85.7 & 13 & 12.9 & 4.1 & 1.5 \\
\hline Rural & 84.6 & 84.7 & 13.4 & 13.3 & 1.9 & 1.9 \\
\hline National & 84.9 & 13.3 & 13.2 & 2.4 & 1.8 \\
\hline
\end{tabular}




\begin{tabular}{|c|c|c|c|c|c|c|}
\hline \multicolumn{2}{|c|}{ Annex Table 3A-2 Parental survival among $15-17$ year olds, Percent (DHS 2010) } \\
\hline \multirow{2}{*}{ Region } & \multicolumn{2}{|c|}{ Both parents alive } & \multicolumn{2}{c|}{ One parent alive } & \multicolumn{2}{c|}{ Neither parent alive } \\
\cline { 2 - 8 } & Females & Males & Females & Males & Females & Males \\
\hline Mainland & & & & & & \\
\hline Arusha & 73.6 & 75.3 & 24 & 23.9 & 2.4 & 0.7 \\
\hline Dar es Salaam & 60.2 & 85 & 26.3 & 10.7 & 13.5 & 4.2 \\
\hline Dodoma & 80.1 & 75.1 & 14.2 & 23 & 5.7 & 1.9 \\
\hline Iringa & 78.5 & 57.4 & 12.4 & 28.3 & 9.2 & 14.3 \\
\hline Kagera & 66.6 & 73.4 & 27.3 & 22 & 6.1 & 4.6 \\
\hline Kigoma & 79.6 & 81.4 & 20.4 & 16.5 & 0 & 2.1 \\
\hline Kilimanjaro & 78.3 & 79.9 & 15 & 18.5 & 6.7 & 1.6 \\
\hline Lindi & 86.8 & 86.5 & 13.2 & 10.5 & 0 & 3 \\
\hline Manyara & 92.3 & 80.4 & 5.8 & 17.7 & 1.9 & 1.9 \\
\hline Mara & 75.6 & 64.8 & 16.7 & 29.7 & 7.7 & 5.5 \\
\hline Mbeya & 77.9 & 71.2 & 9.6 & 26.2 & 12.5 & 2.6 \\
\hline Morogoro & 87.3 & 77.3 & 12.7 & 18.1 & 0 & 4.6 \\
\hline Mtwara & 75 & 89.5 & 25 & 10.5 & 0 & 0 \\
\hline Mwanza & 82.2 & 80.7 & 13.9 & 13.4 & 4 & 5.9 \\
\hline Pwani & 82.9 & 76.3 & 14.5 & 18 & 2.6 & 5.7 \\
\hline Rukwa & 76.9 & 82.5 & 18.6 & 11.7 & 4.5 & 5.7 \\
\hline Ruvuma & 74 & 75.3 & 21.6 & 20.2 & 4.4 & 4.5 \\
\hline Shinyanga & 83.5 & 83 & 16.5 & 14.8 & 0 & 1.2 \\
\hline Singida & 87.7 & 87.7 & 12.3 & 9.6 & 0 & 1.7 \\
\hline Tabora & 75.3 & 82.7 & 21.7 & 13.7 & 3.1 & 3.6 \\
\hline Tanga & 71.9 & 72.2 & 24.7 & 26.2 & 0 & 1.6 \\
\hline Zanzibar & & & & & & \\
\hline Kaskazini Unguja & 79.8 & 85.1 & 18.9 & 13.5 & 1.3 & 1.4 \\
\hline Kusini Unguja & 84.1 & 87.3 & 15.9 & 12.7 & 0 & 0 \\
\hline Mjini Magharibi & 87.4 & 85.6 & 12.6 & 9.9 & 0 & 4.4 \\
\hline Kaskazini Pemba & 92 & 97.7 & 8 & 1.1 & 0 & 1.3 \\
\hline Kusini Pemba & 86.6 & 92.2 & 12.5 & 7.8 & 0.9 & 0 \\
\hline Mainland & 77 & 77.3 & 18 & 18.6 & 4.9 & 4 \\
\hline Zanzibar & 86.6 & 89.3 & 13 & 8.7 & 0.4 & 2 \\
\hline Urban & 74.1 & 79.7 & 21.1 & 12.6 & 4.8 & 7.7 \\
\hline Rural & 78.7 & 77.1 & 16.4 & 20.1 & 4.6 & 2.6 \\
\hline National & 77.7 & 17.8 & 18.3 & 4.7 & 3.9 \\
\hline
\end{tabular}




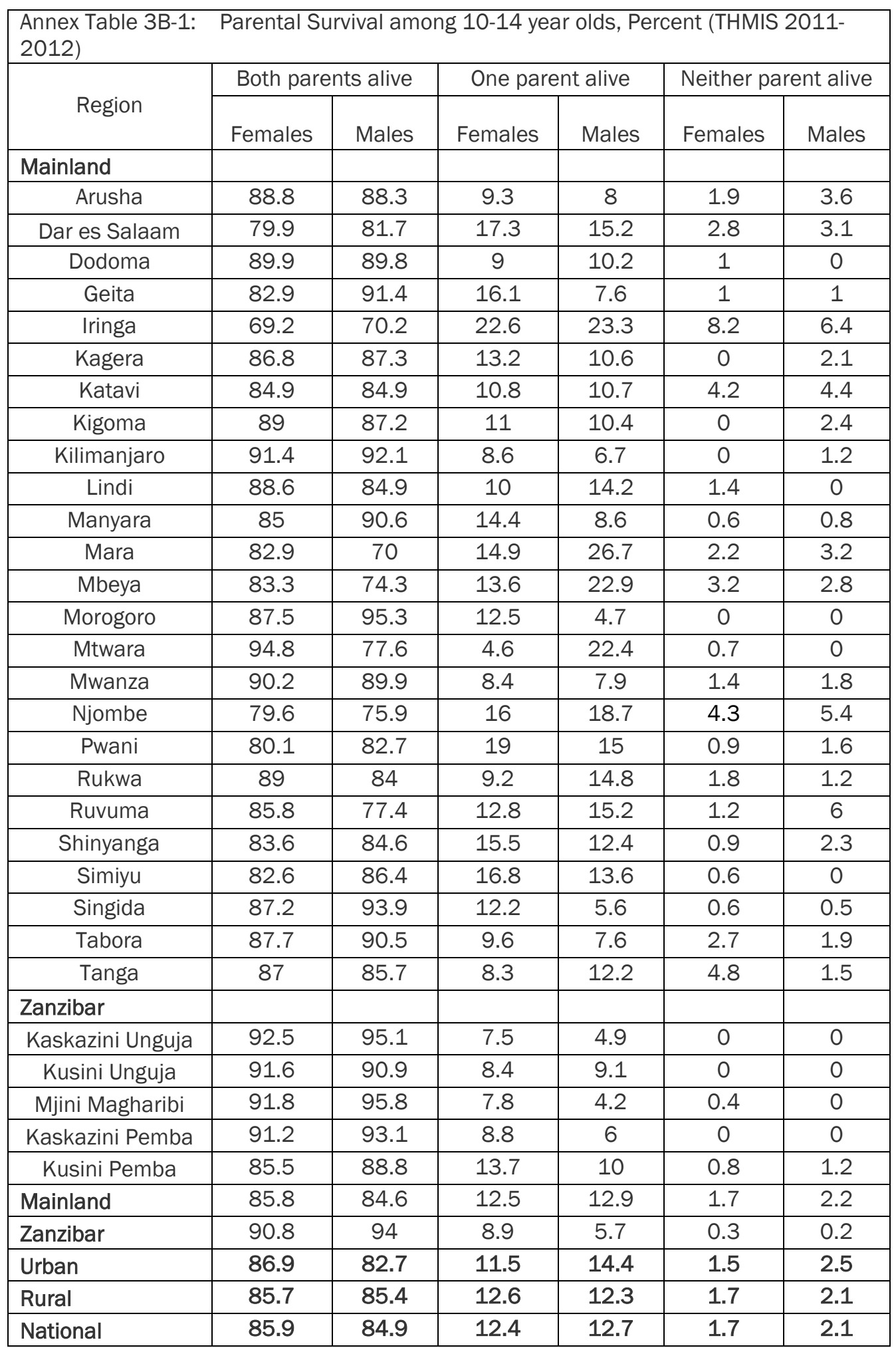




\begin{tabular}{|c|c|c|c|c|c|c|}
\hline \multicolumn{7}{|c|}{$\begin{array}{l}\text { Annex Table 3B-2: Parental Survival among 15-17 year olds, Percent (THMIS 2011- } \\
\text { 2012) }\end{array}$} \\
\hline \multirow{2}{*}{ Region } & \multicolumn{2}{|c|}{ Both parents alive } & \multicolumn{2}{|c|}{ One parent alive } & \multicolumn{2}{|c|}{ Neither parent alive } \\
\hline & Females & Males & Females & Males & Females & Males \\
\hline \multicolumn{7}{|l|}{ Mainland } \\
\hline Arusha & 88.2 & 87.7 & 10.7 & 7.3 & 1.1 & 5 \\
\hline Dar es Salaam & 82.7 & 73.3 & 13.3 & 25.2 & 4 & 1.5 \\
\hline Dodoma & * & 91.2 & * & 4.3 & * & 4.6 \\
\hline Geita & 77 & 81.4 & 18 & 15.7 & 4.9 & 1.1 \\
\hline Iringa & 62.5 & 63.4 & 27.6 & 26.3 & 9.8 & 10.2 \\
\hline Kagera & 81 & 79.6 & 16.3 & 15.9 & 2.6 & 4.5 \\
\hline Katavi & 68.7 & 85.6 & 24.2 & 14.4 & 7 & 0 \\
\hline Kigoma & 82.7 & 76.3 & 17.3 & 23 & 0 & 0.7 \\
\hline Kilimanjaro & 79.3 & 77.6 & 17.2 & 22.4 & 1.8 & 0 \\
\hline Lindi & 74.6 & 83.8 & 21 & 9.2 & 4.4 & 7 \\
\hline Manyara & 92.1 & 87 & 7.9 & 12.3 & 0 & 0.7 \\
\hline Mara & 62.6 & 76 & 29.4 & 22.7 & 7.5 & 1.3 \\
\hline Mbeya & 74.5 & 68 & 18.4 & 22 & 7.1 & 9.9 \\
\hline Morogoro & 81.8 & 81.1 & 18.2 & 18.9 & 0 & 0 \\
\hline Mtwara & 78.5 & 79.5 & 21.5 & 20.5 & 0 & 0 \\
\hline Mwanza & 83.9 & 76 & 14.7 & 14.8 & 1.4 & 6.9 \\
\hline Njombe & 69.9 & 74 & 27.1 & 19 & 3.1 & 7 \\
\hline Pwani & 80.4 & 75.1 & 14.6 & 17.3 & 4.9 & 7.5 \\
\hline Rukwa & 76.2 & 85.4 & 20.1 & 12.1 & 3.8 & 2.5 \\
\hline Ruvuma & 67.1 & 82.6 & 31.5 & 12.5 & 1.4 & 4.8 \\
\hline Shinyanga & 88.5 & 86.4 & 11.5 & 13.6 & 0 & 0 \\
\hline Simiyu & 90.5 & 92.1 & 7.5 & 7.9 & 2 & 0 \\
\hline Singida & 81 & 76 & 16 & 18.5 & 3 & 5.5 \\
\hline Tabora & 76.3 & 85.1 & 17.4 & 12.8 & 6.4 & 2 \\
\hline Tanga & 82.3 & 77.6 & 16.3 & 11.1 & 1.4 & 11.3 \\
\hline \multicolumn{7}{|l|}{ Zanzibar } \\
\hline Kaskazini Unguja & 100 & 88.5 & 0 & 11.5 & 0 & 0 \\
\hline Kusini Unguja & 87.3 & 83.4 & 12.7 & 13.6 & 0 & 3 \\
\hline Mjini Magharibi & 86.6 & 88.1 & 8 & 11.9 & 5.4 & 0 \\
\hline Kaskazini Pemba & 88.3 & 82.3 & 11.7 & 17.7 & 0 & 0 \\
\hline Kusini Pemba & 85.9 & 79.5 & 12.1 & 20.5 & 2 & 0 \\
\hline Mainland & 79.4 & 79.8 & 17.3 & 16.2 & 3.2 & 3.7 \\
\hline Zanzibar & 88.2 & 85.5 & 8.5 & 14.3 & 3.3 & 0.2 \\
\hline Urban & 76.6 & 75.4 & 19.7 & 20.3 & 3.7 & 4.3 \\
\hline Rural & 81.1 & 81.3 & 15.9 & 15.1 & 3 & 3.4 \\
\hline National & 79.8 & 80.1 & 17 & 16.2 & 3.2 & 3.6 \\
\hline
\end{tabular}




\begin{tabular}{|c|c|c|c|c|c|c|}
\hline \multicolumn{7}{|c|}{$\begin{array}{l}\text { Annex Table 4-A3: Current School Attendance }{ }^{a} \text { among 15-17 year olds, Percent (DHS } \\
\text { 2010) }\end{array}$} \\
\hline \multirow[b]{2}{*}{ Region } & \multicolumn{3}{|c|}{ Females (\% within sex for age) } & \multicolumn{3}{|c|}{ Males (\% within sex for age) } \\
\hline & $\begin{array}{l}\text { Not in } \\
\text { school }\end{array}$ & $\begin{array}{c}\text { Attending } \\
\text { primary }\end{array}$ & $\begin{array}{l}\text { Attending } \\
\text { secondary }\end{array}$ & $\begin{array}{l}\text { Not in } \\
\text { school }\end{array}$ & $\begin{array}{l}\text { Attending } \\
\text { primary }\end{array}$ & $\begin{array}{l}\text { Attending } \\
\text { secondary }\end{array}$ \\
\hline \multicolumn{7}{|l|}{ Mainland } \\
\hline Arusha & 39.9 & 14 & 46.1 & 48.8 & 34.3 & 16.9 \\
\hline Dar es Salaam & 49.2 & 8 & 42.9 & 38.8 & 11.4 & 49.8 \\
\hline Dodoma & 64.9 & 13.8 & 21.3 & 44.9 & 48.2 & 6.9 \\
\hline Iringa & 44.7 & 8.3 & 47.1 & 39.2 & 14.5 & 46.3 \\
\hline Kagera & 45.9 & 35.8 & 18.3 & 47.5 & 29 & 23.5 \\
\hline Kigoma & 60.4 & 22.7 & 16.8 & 24.4 & 35.4 & 40.2 \\
\hline Kilimanjaro & 15.8 & 13.9 & 70.3 & 30.4 & 24.2 & 45.4 \\
\hline Lindi & 68.4 & 27.6 & 3.9 & 65.4 & 14.4 & 20.2 \\
\hline Manyara & 54 & 22.4 & 23.6 & 46.9 & 27.2 & 25.9 \\
\hline Mara & 72.3 & 8.2 & 19.5 & 50.7 & 29 & 20.3 \\
\hline Mbeya & 62.3 & 11.8 & 25.9 & 57.2 & 24.1 & 18.7 \\
\hline Morogoro & 45.8 & 12.8 & 41.4 & 50.7 & 22.7 & 26.5 \\
\hline Mtwara & 52.6 & 15.3 & 32 & 44.2 & 22.9 & 32.9 \\
\hline Mwanza & 51.8 & 22.8 & 25.5 & 46.5 & 22.8 & 30.7 \\
\hline Pwani & 42.9 & 28.9 & 28.2 & 34.1 & 38.9 & 27 \\
\hline Rukwa & 70 & 23.2 & 6.8 & 28.6 & 51.2 & 20.2 \\
\hline Ruvuma & 52.3 & 14.2 & 33.5 & 51.1 & 17.5 & 31.4 \\
\hline Shinyanga & 65.3 & 23.6 & 11.1 & 38.2 & 45.8 & 16 \\
\hline Singida & 52 & 15.7 & 32.4 & 56.3 & 22.6 & 21 \\
\hline Tabora & 65.2 & 14.4 & 20.4 & 48.5 & 30.4 & 21.1 \\
\hline Tanga & 42.3 & 16.5 & 41.2 & 34.6 & 44.8 & 20.6 \\
\hline \multicolumn{7}{|l|}{ Zanzibar } \\
\hline $\begin{array}{l}\text { Kaskazini } \\
\text { Unguja }\end{array}$ & 28.9 & 26.3 & 44.8 & 40.7 & 33.6 & 25.7 \\
\hline Kusini Unguja & 28.7 & 9.3 & 62 & 36.9 & 18.2 & 44.9 \\
\hline Mjini Magharibi & 16.9 & 9.4 & 73.6 & 17.7 & 19.8 & 62.5 \\
\hline $\begin{array}{l}\text { Kaskazini } \\
\text { Pemba }\end{array}$ & 27.8 & 21 & 51.3 & 26.3 & 44 & 29.7 \\
\hline Kusini Pemba & 26.6 & 27.3 & 46 & 23.3 & 35.1 & 41.6 \\
\hline Mainland & 53.2 & 17.5 & 29.3 & 44 & 28.8 & 27.2 \\
\hline Zanzibar & 24.4 & 18.5 & 57.1 & 26.3 & 29.7 & 44 \\
\hline Urban & 38.6 & 10.3 & 51.1 & 29.2 & 18.2 & 52.6 \\
\hline Rural & 57.8 & 20.5 & 21.7 & 47.8 & 32.2 & 20 \\
\hline National & 52.2 & 17.5 & 30.2 & 43.4 & 28.8 & 27.8 \\
\hline
\end{tabular}




\begin{tabular}{|c|c|c|c|c|c|c|}
\hline \multicolumn{7}{|c|}{$\begin{array}{l}\text { Annex Table 4-A4: Current School Attendance }{ }^{a} \text { among } 18-19 \text { year olds, Percent (DHS } \\
\text { 2010) }\end{array}$} \\
\hline \multirow[b]{2}{*}{ Region } & \multicolumn{3}{|c|}{ Females (\% within sex for age) } & \multicolumn{3}{|c|}{ Males (\% within sex for age) } \\
\hline & $\begin{array}{l}\text { Not in } \\
\text { school }\end{array}$ & $\begin{array}{l}\text { Attending } \\
\text { primary }\end{array}$ & $\begin{array}{l}\text { Attending } \\
\text { secondary }\end{array}$ & $\begin{array}{l}\text { Not in } \\
\text { school }\end{array}$ & $\begin{array}{l}\text { Attending } \\
\text { primary }\end{array}$ & $\begin{array}{l}\text { Attending } \\
\text { secondary }\end{array}$ \\
\hline \multicolumn{7}{|l|}{ Mainland } \\
\hline Arusha & 57.5 & 13.7 & 28.9 & 57.5 & 13.7 & 28.9 \\
\hline Dar es Salaam & 56.8 & 0 & 43.2 & 56.8 & 0 & 43.2 \\
\hline Dodoma & * & * & * & 77.5 & 4.9 & 17.6 \\
\hline Iringa & * & * & * & 59.3 & 1.5 & 39.2 \\
\hline Kagera & 56.9 & 5.9 & 37.2 & 56.9 & 5.9 & 37.2 \\
\hline Kigoma & 47.4 & 4.3 & 48.3 & 47.4 & 4.3 & 48.3 \\
\hline Kilimanjaro & 47.2 & 2.9 & 49.8 & 47.2 & 2.9 & 49.8 \\
\hline Lindi & 74.3 & 0 & 25.7 & * & * & * \\
\hline Manyara & * & * & * & 47.8 & 0 & 52.2 \\
\hline Mara & 55.2 & 2.3 & 42.5 & 55.2 & 2.3 & 42.5 \\
\hline Mbeya & 56.4 & 19.2 & 24.4 & 56.4 & 19.2 & 24.4 \\
\hline Morogoro & 62.9 & 8.8 & 28.3 & 62.9 & 8.8 & 28.3 \\
\hline Mtwara & * & * & * & 69.1 & 0 & 30.9 \\
\hline Mwanza & 56.3 & 10.1 & 33.6 & 56.3 & 10.1 & 33.6 \\
\hline Pwani & * & * & * & 60.2 & 10 & 29.8 \\
\hline Rukwa & 72.3 & 6.4 & 21.3 & 72.3 & 6.4 & 21.3 \\
\hline Ruvuma & * & * & * & 67 & 4.4 & 28.6 \\
\hline Shinyanga & 67.1 & 10.4 & 22.4 & 67.1 & 10.4 & 22.4 \\
\hline Singida & * & * & * & 78.9 & 1.5 & 19.6 \\
\hline Tabora & 74.7 & 11.6 & 13.7 & 74.7 & 11.6 & 13.7 \\
\hline Tanga & * & * & * & * & * & * \\
\hline \multicolumn{7}{|l|}{ Zanzibar } \\
\hline $\begin{array}{l}\text { Kaskazini } \\
\text { Unguja }\end{array}$ & 55.7 & 5.5 & 38.9 & 55.7 & 5.5 & 38.9 \\
\hline Kusini Unguja & 71.6 & 0 & 28.4 & 71.6 & 0 & 28.4 \\
\hline Mjini Magharibi & 51 & 3 & 46.1 & 51 & 3 & 46.1 \\
\hline $\begin{array}{l}\text { Kaskazini } \\
\text { Pemba }\end{array}$ & 43.4 & 1.7 & 54.9 & 43.4 & 1.7 & 54.9 \\
\hline Kusini Pemba & 43 & 8.3 & 48.7 & 43 & 8.3 & 48.7 \\
\hline Mainland & 76.8 & 1.8 & 21.4 & 61.4 & 6.5 & 32.1 \\
\hline Zanzibar & 51.8 & 1.2 & 47 & 50.4 & 4 & 45.7 \\
\hline Urban & 52.2 & 1.7 & 46.1 & 52.2 & 1.7 & 46.1 \\
\hline Rural & 64 & 8.1 & 28 & 64 & 8.1 & 28 \\
\hline National & 61 & 6.5 & 32.5 & 61 & 6.5 & 32.5 \\
\hline
\end{tabular}




\begin{tabular}{|c|c|c|c|c|c|c|c|c|c|c|}
\hline \multirow{3}{*}{$\begin{array}{c}\text { Annex Table } \\
\text { Region }\end{array}$} & \multirow{2}{*}{\multicolumn{2}{|c|}{$\frac{\text {-5: Adolescents Not }}{\text { Age } 10}$}} & \multirow{2}{*}{\multicolumn{2}{|c|}{$\begin{array}{c}\text { School, 10-14 yea } \\
\text { Age } 11 \\
\end{array}$}} & \multirow{2}{*}{\multicolumn{2}{|c|}{$\begin{array}{c}\text { blds, Percent (DHS } 2 \\
\text { Age } 12\end{array}$}} & \multirow{2}{*}{\multicolumn{2}{|c|}{ Age 13}} & \multirow{2}{*}{\multicolumn{2}{|c|}{ Age 14}} \\
\hline & & & & & & & & & & \\
\hline & Females & Males & Females & Males & Females & Males & Females & Males & Females & Males \\
\hline \multicolumn{11}{|l|}{ Mainland } \\
\hline Arusha & 4.7 & 13.2 & * & * & 10 & * & * & 13.3 & * & * \\
\hline $\begin{array}{l}\text { Dar es } \\
\text { Salaam }\end{array}$ & * & * & * & * & * & * & * & * & * & * \\
\hline Dodoma & * & * & 16.7 & 20.4 & * & 21.5 & 17.4 & * & * & * \\
\hline Iringa & * & * & * & * & * & * & * & * & 27.5 & * \\
\hline Kagera & 23.1 & 15.3 & * & * & 13.4 & * & 30.5 & 20.5 & * & * \\
\hline Kigoma & 8.2 & 0 & 12 & 3.2 & 7.6 & * & * & * & 56.5 & 27.7 \\
\hline Kilimanjaro & * & * & * & 0 & * & 0 & 0 & 13.7 & * & * \\
\hline Lindi & * & * & * & * & * & * & * & * & * & * \\
\hline Manyara & * & 7 & * & 6 & 7 & 6.8 & 15.9 & * & 34 & * \\
\hline Mara & 4.5 & 0 & 5 & 4.5 & * & 7 & 13.7 & 17.1 & 25.9 & * \\
\hline Mbeya & 6.9 & * & 8 & * & 5.8 & * & * & 11 & 58.6 & 39.5 \\
\hline Morogoro & 9.7 & * & * & * & * & 15.4 & 25.8 & * & 47.7 & 46.7 \\
\hline Mtwara & * & * & * & * & 9.7 & * & * & * & * & * \\
\hline Mwanza & 3.8 & 18.3 & 8.1 & 21.9 & 12.1 & 6.1 & 21.8 & 18.6 & 42.6 & 23.2 \\
\hline Pwani & 10.1 & 9.7 & 0 & 3.9 & $*$ & * & $*$ & * & $*$ & * \\
\hline Rukwa & 13.5 & 5.9 & 25.3 & 13.7 & 18.1 & 16.6 & 15.7 & 16.1 & * & * \\
\hline Ruvuma & 0 & 4.2 & 2.4 & 0 & 3.5 & * & * & * & * & 15.5 \\
\hline Shinyanga & 12.5 & 20.7 & 13.2 & 14.7 & 7.3 & 15.1 & 17.2 & 15.8 & 25.5 & 22.1 \\
\hline Singida & 0 & 11.4 & 4.9 & 9.1 & 7.8 & * & 9.7 & 6.6 & * & 17.1 \\
\hline Tabora & 23.2 & 25.5 & 34.6 & 29.7 & 31 & 10.9 & 22.6 & 17.4 & 37.4 & 25.9 \\
\hline Tanga & 0 & $*$ & 20.6 & 10.2 & 0 & 8.6 & 17.7 & 12.8 & $*$ & 21 \\
\hline \multicolumn{11}{|l|}{ Zanzibar } \\
\hline $\begin{array}{c}\text { Kaskazini } \\
\text { Unguja }\end{array}$ & 7.5 & 16.3 & 0 & 10.5 & 8.3 & 10.7 & 4.9 & * & * & 25.8 \\
\hline $\begin{array}{l}\text { Kusini } \\
\text { Unguja }\end{array}$ & 0 & 2.8 & 0 & 3.8 & 0 & * & 3.7 & * & 8.4 & 9.6 \\
\hline $\begin{array}{c}\text { Mjini } \\
\text { Magharibi }\end{array}$ & 3 & 0 & 0 & 0 & 4.3 & 7.3 & 6.3 & 2.9 & * & 0 \\
\hline $\begin{array}{c}\text { Kaskazini } \\
\text { Pemba }\end{array}$ & 20.8 & 28 & 14.2 & 5.7 & 9.9 & 9.9 & 4.1 & 8.3 & 20.8 & 14.2 \\
\hline $\begin{array}{l}\text { Kusini } \\
\text { Pemba }\end{array}$ & 0 & 17.7 & 7.9 & 6.7 & 0 & 7.8 & 7.8 & 6.6 & 6.2 & 12.9 \\
\hline Mainland & 8.4 & 11.8 & 10.4 & 10.5 & 10.3 & 11.8 & 18.5 & 16.5 & 34.4 & 24.5 \\
\hline Zanzibar & 5.7 & 11.5 & 4.3 & 4.1 & 4.9 & 8.3 & 5.8 & 6.3 & 7.5 & 9.8 \\
\hline Urban & 2 & 2.8 & 3.3 & 1.8 & 8.3 & 6.2 & 22.7 & 13 & 24.3 & 25.6 \\
\hline Rural & 10 & 13.7 & 12 & 12.8 & 10.6 & 12.8 & 16.6 & 17.1 & 36.3 & 23.6 \\
\hline National & 8.4 & 11.8 & 10.2 & 10.4 & 10.2 & 11.7 & 18.2 & 16.2 & 33.8 & 24 \\
\hline
\end{tabular}




\begin{tabular}{|c|c|c|c|c|c|c|}
\hline \multicolumn{7}{|c|}{$\begin{array}{l}\text { Annex Table 4B-1: THMIS 2011-2, Current School Attendance }{ }^{a} \text { among 10-14 year olds, } \\
\text { Percent }\end{array}$} \\
\hline \multirow[b]{2}{*}{ Region } & \multicolumn{3}{|c|}{ Females (\% within sex for age) } & \multicolumn{3}{|c|}{ Males (\% within sex for age) } \\
\hline & $\begin{array}{l}\text { Not in } \\
\text { school }\end{array}$ & $\begin{array}{l}\text { Attending } \\
\text { primary }\end{array}$ & $\begin{array}{l}\text { Attending } \\
\text { secondary }\end{array}$ & $\begin{array}{l}\text { Not in } \\
\text { school }\end{array}$ & $\begin{array}{l}\text { Attending } \\
\text { primary }\end{array}$ & $\begin{array}{l}\text { Attending } \\
\text { secondary }\end{array}$ \\
\hline \multicolumn{7}{|l|}{ Mainland } \\
\hline Arusha & 2.8 & 92.5 & 3.9 & 15.9 & 83.6 & 0.5 \\
\hline Dar es Salaam & 4.3 & 85.9 & 9.8 & 10.2 & 77.1 & 12.7 \\
\hline Dodoma & 15.5 & 83.4 & 0.4 & 25 & 72.4 & 1.1 \\
\hline Geita & 16.1 & 82.9 & 0.3 & 19 & 80.3 & 0 \\
\hline Iringa & 2.6 & 95.6 & 1.7 & 5.1 & 88.1 & 3.8 \\
\hline Kagera & 9 & 88 & 2.2 & 9.3 & 89.7 & 0 \\
\hline Katavi & 30.2 & 69 & 0.5 & 28.2 & 69.9 & 0.7 \\
\hline Kigoma & 7.6 & 86.2 & 5.6 & 11.3 & 85.9 & 2.5 \\
\hline Kilimanjaro & 3.8 & 85.8 & 10.4 & 5 & 85 & 10 \\
\hline Lindi & 6.7 & 91.7 & 1.5 & 20.8 & 78.3 & 1 \\
\hline Manyara & 14.9 & 81.8 & 1.9 & 19.2 & 79.1 & 0.8 \\
\hline Mara & 9 & 88.1 & 2.9 & 8.5 & 89.1 & 2.4 \\
\hline Mbeya & 12.3 & 82.9 & 4.8 & 20.9 & 76.5 & 2.6 \\
\hline Morogoro & 14.9 & 82.4 & 2.7 & 17.3 & 80.5 & 2.2 \\
\hline Mtwara & 6.2 & 92.3 & 1.4 & 10 & 86.9 & 3.1 \\
\hline Mwanza & 6.5 & 90.7 & 2.8 & 10.7 & 86 & 2.9 \\
\hline Njombe & 4 & 94.6 & 1.4 & 4.5 & 95 & 0.5 \\
\hline Pwani & 6 & 92.5 & 0.7 & 9.6 & 89.5 & 0.9 \\
\hline Rukwa & 19.1 & 79.8 & 0.4 & 22.1 & 77.9 & 0 \\
\hline Ruvuma & 13.5 & 83.9 & 2.6 & 4.4 & 91.1 & 4.5 \\
\hline Shinyanga & 19.9 & 77.6 & 2.5 & 20.6 & 79.4 & 0 \\
\hline Simiyu & 13.3 & 85.2 & 0.5 & 16.6 & 80.2 & 0 \\
\hline Singida & 16.2 & 82.1 & 1.7 & 17.3 & 78.3 & 1.9 \\
\hline Tabora & 19.3 & 79.7 & 1 & 26.1 & 73.2 & 0.3 \\
\hline Tanga & 9.7 & 86.1 & 4.1 & 9.8 & 86.9 & 1.5 \\
\hline \multicolumn{7}{|l|}{ Zanzibar } \\
\hline $\begin{array}{l}\text { Kaskazini } \\
\text { Unguja }\end{array}$ & 5 & 92.5 & 1.7 & 14.3 & 83.5 & 0.9 \\
\hline Kusini Unguja & 0 & 97.5 & 2.5 & 3 & 93.7 & 3.3 \\
\hline $\begin{array}{c}\text { Mjini } \\
\text { Magharibi }\end{array}$ & 2.1 & 92.6 & 5.3 & 1.2 & 98.3 & 0.5 \\
\hline $\begin{array}{l}\text { Kaskazini } \\
\text { Pemba }\end{array}$ & 12.9 & 86.1 & 0.9 & 12.9 & 87.1 & 0 \\
\hline Kusini Pemba & 5.7 & 91.2 & 3.1 & 13.9 & 84.2 & 1.9 \\
\hline Mainland & 11.5 & 85.3 & 3 & 14.2 & 82.5 & 2.6 \\
\hline Zanzibar & 4.4 & 91.8 & 3.7 & 7 & 92 & 0.8 \\
\hline Urban & 4.9 & 87.3 & 7.8 & 4.2 & 88.9 & 6.9 \\
\hline Rural & 12.8 & 85 & 1.8 & 16.1 & 81.5 & 1.6 \\
\hline National & 11.2 & 85.5 & 3 & 14 & 82.8 & 2.5 \\
\hline
\end{tabular}




\begin{tabular}{|c|c|c|c|c|c|c|}
\hline \multicolumn{7}{|c|}{$\begin{array}{l}\text { Annex Table 4B-2: THMIS 2011-2, Current School Attendance a among 15-19 year olds, } \\
\text { Percent }\end{array}$} \\
\hline \multirow[b]{2}{*}{ Region } & \multicolumn{3}{|c|}{ Females (\% within sex for age) } & \multicolumn{3}{|c|}{ Males (\% within sex for age) } \\
\hline & $\begin{array}{l}\text { Not in } \\
\text { school }\end{array}$ & $\begin{array}{l}\text { Attending } \\
\text { primary }\end{array}$ & $\begin{array}{l}\text { Attending } \\
\text { secondary }\end{array}$ & $\begin{array}{l}\text { Not in } \\
\text { school }\end{array}$ & $\begin{array}{l}\text { Attending } \\
\text { primary }\end{array}$ & $\begin{array}{l}\text { Attending } \\
\text { secondary }\end{array}$ \\
\hline \multicolumn{7}{|l|}{ Mainland } \\
\hline Arusha & 45.3 & 14.3 & 40.4 & 28.3 & 34.1 & 37.6 \\
\hline Dar es Salaam & 63 & 8.8 & 28.2 & 42 & 3.6 & 54.4 \\
\hline Dodoma & 71.1 & 18.6 & 10.2 & 55.1 & 29.4 & 15.5 \\
\hline Geita & 62.2 & 29.8 & 8.1 & 51.5 & 37.6 & 11 \\
\hline Iringa & 39.3 & 24 & 36.7 & 37.1 & 31.8 & 31.2 \\
\hline Kagera & 46.4 & 35.4 & 18.2 & 39.6 & 40.9 & 19.5 \\
\hline Katavi & 66.8 & 23.4 & 9.8 & 49.3 & 30.2 & 20.4 \\
\hline Kigoma & 62 & 18.7 & 19.3 & 39.4 & 23 & 37.6 \\
\hline Kilimanjaro & 29.9 & 10.4 & 59.6 & 36.3 & 11.8 & 51.8 \\
\hline Lindi & 46.7 & 28.2 & 25.1 & 51.2 & 23.8 & 25 \\
\hline Manyara & 46.9 & 30.9 & 22.2 & 42.8 & 26 & 31.2 \\
\hline Mara & 63.8 & 20.9 & 15.3 & 48.1 & 35.5 & 15.9 \\
\hline Mbeya & 46 & 21.4 & 32.6 & 43 & 25.9 & 31.1 \\
\hline Morogoro & 64.5 & 7.5 & 28 & 47.1 & 19.8 & 33.1 \\
\hline Mtwara & 53.2 & 20.3 & 26.6 & 42.8 & 12.4 & 44.8 \\
\hline Mwanza & 54.6 & 21.5 & 23.9 & 34.9 & 34.7 & 30.5 \\
\hline Njombe & 38.3 & 20.7 & 41 & 51.4 & 18.5 & 30.1 \\
\hline Pwani & 52.6 & 17.6 & 29.9 & 31.5 & 28.8 & 39.7 \\
\hline Rukwa & 48.5 & 24.7 & 26.8 & 44.2 & 31.1 & 24.8 \\
\hline Ruvuma & 56.2 & 17.5 & 26.3 & 40.2 & 30.2 & 29.6 \\
\hline Shinyanga & 66.2 & 20.1 & 13.7 & 56.8 & 24.6 & 18.6 \\
\hline Simiyu & 69.7 & 19.5 & 10.8 & 53.1 & 33.7 & 12.7 \\
\hline Singida & 64.9 & 9.2 & 25.9 & 59.1 & 15.8 & 25 \\
\hline Tabora & 57.3 & 24.1 & 18.6 & 54.9 & 26.2 & 19 \\
\hline Tanga & 44.6 & 16.5 & 38.9 & 56.2 & 18.3 & 25.5 \\
\hline \multicolumn{7}{|l|}{ Zanzibar } \\
\hline $\begin{array}{c}\text { Kaskazini } \\
\text { Unguja }\end{array}$ & 32.1 & 22.2 & 45.7 & 41.3 & 28.9 & 29.9 \\
\hline Kusini Unguja & 30.7 & 11.2 & 58 & 28.5 & 13.8 & 57.7 \\
\hline Mjini Magharibi & 34.5 & 3 & 62.5 & 23.2 & 18.3 & 58.5 \\
\hline Kaskazini & & & & & & \\
\hline Pemba & 29.1 & 33.4 & 37.4 & 39.1 & 41.1 & 19.7 \\
\hline Kusini Pemba & 25.1 & 20.3 & 54.6 & 30.8 & 31.3 & 37.9 \\
\hline Mainland & 56.2 & 19.1 & 24.8 & 45.6 & 25.4 & 28.9 \\
\hline Zanzibar & 32 & 12 & 56 & 29 & 24.3 & 46.7 \\
\hline Urban & 49.8 & 11.7 & 38.5 & 29.9 & 15.1 & 54.9 \\
\hline Rural & 57.3 & 21.5 & 21.2 & 49.6 & 28.6 & 21.8 \\
\hline National & 55.2 & 18.8 & 26 & 44.9 & 25.4 & 29.6 \\
\hline
\end{tabular}




\begin{tabular}{|c|c|c|c|c|c|c|}
\hline \multicolumn{7}{|c|}{$\begin{array}{l}\text { Annex Table 4B-3: THMIS 2011-2, Current School Attendance a among 15-17 year olds, } \\
\text { Percent }\end{array}$} \\
\hline \multirow[b]{2}{*}{ Region } & \multicolumn{3}{|c|}{ Females (\% within sex for age) } & \multicolumn{3}{|c|}{ Males (\% within sex for age) } \\
\hline & $\begin{array}{l}\text { Not in } \\
\text { school }\end{array}$ & $\begin{array}{l}\text { Attending } \\
\text { primary }\end{array}$ & $\begin{array}{l}\text { Attending } \\
\text { secondary }\end{array}$ & $\begin{array}{l}\text { Not in } \\
\text { school }\end{array}$ & $\begin{array}{l}\text { Attending } \\
\text { primary }\end{array}$ & $\begin{array}{l}\text { Attending } \\
\text { secondary }\end{array}$ \\
\hline \multicolumn{7}{|l|}{ Mainland } \\
\hline Arusha & 34.7 & 23 & 42.3 & 29.1 & 40.5 & 30.4 \\
\hline Dar es Salaam & 54.4 & 15.7 & 29.9 & 31.7 & 7.5 & 60.8 \\
\hline Dodoma & * & * & * & 43.8 & 43.3 & 12.9 \\
\hline Geita & 46.9 & 43.7 & 9.4 & 41.4 & 52.8 & 5.9 \\
\hline Iringa & 22.6 & 40.4 & 37 & 32.2 & 35.9 & 31.9 \\
\hline Kagera & 31 & 49 & 20 & 27 & 57.5 & 15.6 \\
\hline Katavi & 60.1 & 33.1 & 6.8 & 42.8 & 38.1 & 19.1 \\
\hline Kigoma & 48.9 & 27.3 & 23.8 & 37.5 & 30 & 32.6 \\
\hline Kilimanjaro & 22.5 & 14.2 & 63.3 & 32.1 & 17.4 & 50.5 \\
\hline Lindi & 30.3 & 42 & 27.7 & 41.1 & 30.5 & 28.4 \\
\hline Manyara & 34.3 & 41.4 & 24.2 & 40.9 & 37.8 & 21.3 \\
\hline Mara & 54.3 & 29 & 16.7 & 34.9 & 47.5 & 16.9 \\
\hline Mbeya & 30.1 & 31.3 & 38.6 & 37.1 & 39.9 & 22.9 \\
\hline Morogoro & 49.5 & 13.9 & 36.7 & 27.6 & 37.3 & 35.2 \\
\hline Mtwara & 43 & 28.9 & 28.1 & 39.6 & 18.3 & 42 \\
\hline Mwanza & 39.4 & 27.3 & 33.4 & 35.7 & 40.8 & 23.5 \\
\hline Njombe & 16.7 & 35.3 & 47.9 & 43.9 & 25.7 & 30.4 \\
\hline Pwani & 40.8 & 26.3 & 32.9 & 26.8 & 33 & 40.2 \\
\hline Rukwa & 42 & 38.6 & 19.4 & 42 & 41.9 & 16.1 \\
\hline Ruvuma & 50.7 & 26.3 & 23 & 36.4 & 36.4 & 27.2 \\
\hline Shinyanga & 55.9 & 29.4 & 14.7 & 50.9 & 30.2 & 18.9 \\
\hline Simiyu & 62.2 & 30.4 & 7.4 & 43.1 & 45 & 11.1 \\
\hline Singida & 66.4 & 16.3 & 17.3 & 53.7 & 23.7 & 22.5 \\
\hline Tabora & 46.4 & 36.4 & 17.2 & 50.3 & 35.8 & 13.8 \\
\hline Tanga & 33.1 & 30.4 & 36.5 & 43.7 & 30.5 & 25.7 \\
\hline \multicolumn{7}{|l|}{ Zanzibar } \\
\hline $\begin{array}{l}\text { Kaskazini } \\
\text { Unguja }\end{array}$ & 25.6 & 27.2 & 47.1 & 34.8 & 37.7 & 27.5 \\
\hline Kusini Unguja & 16.7 & 18.8 & 64.5 & 9.6 & 22.4 & 68 \\
\hline Mjini Magharibi & 22.1 & 5 & 73 & 15.2 & 33.3 & 51.6 \\
\hline $\begin{array}{l}\text { Kaskazini } \\
\text { Pemba }\end{array}$ & 20.4 & 51.6 & 27.9 & 28.2 & 59.9 & 11.9 \\
\hline Kusini Pemba & 10.1 & 30.9 & 59 & 23.8 & 43.1 & 33 \\
\hline Mainland & 44.6 & 29.2 & 26.2 & 38.6 & 35.8 & 25.5 \\
\hline Zanzibar & 20.3 & 18.3 & 61.4 & 20.4 & 38 & 41.6 \\
\hline Urban & 41.6 & 17.2 & 41.1 & 21.6 & 23.1 & 55.1 \\
\hline Rural & 44.4 & 33.3 & 22.3 & 42.4 & 39.3 & 18.3 \\
\hline National & 43.6 & 28.7 & 27.6 & 38 & 35.8 & 26.1 \\
\hline
\end{tabular}




\begin{tabular}{|c|c|c|c|c|c|c|}
\hline \multicolumn{7}{|c|}{$\begin{array}{l}\text { Annex Table 4B-4: THMIS 2011-2, Current School Attendancea among 18-19 year olds, } \\
\text { Percent }\end{array}$} \\
\hline \multirow[b]{2}{*}{ Region } & \multicolumn{3}{|c|}{ Females (\% within sex for age) } & \multicolumn{3}{|c|}{ Males (\% within sex for age) } \\
\hline & $\begin{array}{l}\text { Not in } \\
\text { school }\end{array}$ & $\begin{array}{l}\text { Attending } \\
\text { primary }\end{array}$ & $\begin{array}{l}\text { Attending } \\
\text { secondary }\end{array}$ & $\begin{array}{l}\text { Not in } \\
\text { school }\end{array}$ & $\begin{array}{l}\text { Attending } \\
\text { primary }\end{array}$ & $\begin{array}{l}\text { Attending } \\
\text { secondary }\end{array}$ \\
\hline \multicolumn{7}{|l|}{ Mainland } \\
\hline Arusha & 62.7 & 0 & 37.3 & 26.8 & 22.5 & 50.7 \\
\hline Dar es Salaam & 72.9 & 0.8 & 26.3 & 51.4 & 0 & 48.6 \\
\hline Dodoma & * & * & * & * & * & * \\
\hline Geita & 91.4 & 3 & 5.6 & 68.8 & 11.3 & 19.8 \\
\hline Iringa & 53.9 & 9.6 & 36.5 & 44.3 & 25.6 & 30.1 \\
\hline Kagera & 71.9 & 12.9 & 15.2 & * & * & * \\
\hline Katavi & 79.3 & 5.3 & 15.4 & * & * & * \\
\hline Kigoma & 77.3 & 8.7 & 14 & 41.2 & 16.6 & 42.2 \\
\hline Kilimanjaro & * & * & * & 41.6 & 4.9 & 53.5 \\
\hline Lindi & * & * & * & * & * & * \\
\hline Manyara & 78.1 & 4.9 & 17 & 45.1 & 11.2 & 43.7 \\
\hline Mara & 78.5 & 8.4 & 13.1 & 74 & 11.9 & 14.1 \\
\hline Mbeya & 71.1 & 5.8 & 23.1 & 51.3 & 6 & 42.7 \\
\hline Morogoro & 82 & 0 & 18 & 67.7 & 1.3 & 30.9 \\
\hline Mtwara & * & * & * & * & * & * \\
\hline Mwanza & 86.2 & 9.6 & 4.2 & 33.6 & 24.7 & 41.8 \\
\hline Njombe & 65.8 & 2 & 32.2 & 65 & 5.3 & 29.7 \\
\hline Pwani & 72.5 & 2.8 & 24.7 & * & * & * \\
\hline Rukwa & * & * & * & 47.6 & 13.7 & 38.6 \\
\hline Ruvuma & 65.3 & 3 & 31.7 & * & * & * \\
\hline Shinyanga & 81.6 & 6.1 & 12.3 & * & * & * \\
\hline Simiyu & 81 & 3.1 & 15.9 & 73.8 & 10 & 16.1 \\
\hline Singida & 63 & 0 & 37 & 67.3 & 3.9 & 28.8 \\
\hline Tabora & 76.5 & 2.4 & 21.1 & 61.5 & 12 & 26.5 \\
\hline Tanga & 56.9 & 1.6 & 41.5 & 71.7 & 3.2 & 25.1 \\
\hline \multicolumn{7}{|l|}{ Zanzibar } \\
\hline $\begin{array}{l}\text { Kaskazini } \\
\text { Unguja }\end{array}$ & 45 & 12.2 & 42.8 & 52.2 & 14 & 33.8 \\
\hline Kusini Unguja & 51.6 & 0 & 48.4 & 58.8 & 0 & 41.2 \\
\hline Mjini Magharibi & 53.4 & 0 & 46.6 & 32.9 & 0 & 67.1 \\
\hline $\begin{array}{l}\text { Kaskazini } \\
\text { Pemba }\end{array}$ & 42.5 & 5.4 & 52 & 53.3 & 16.9 & 29.8 \\
\hline Kusini Pemba & 50 & 2.7 & 47.3 & 42.5 & 11.5 & 46.1 \\
\hline Mainland & 73.4 & 4 & 22.6 & 56.3 & 9.6 & 34.2 \\
\hline Zanzibar & 50.6 & 2.2 & 47.3 & 40.8 & 5.4 & 53.9 \\
\hline Urban & 62.9 & 2.7 & 34.4 & 39.9 & 5.5 & 54.6 \\
\hline Rural & 76 & 4.4 & 19.6 & 61.5 & 10.9 & 27.6 \\
\hline National & 72.5 & 3.9 & 23.5 & 55.6 & 9.4 & 35 \\
\hline
\end{tabular}




\begin{tabular}{|c|c|c|c|c|c|c|c|c|c|c|}
\hline \multicolumn{11}{|c|}{ Annex Table 4B-5: THMIS 2011-12, Adolescents Not in School, 10-14 year olds, Percent } \\
\hline \multirow[b]{2}{*}{ Region } & \multicolumn{2}{|c|}{ Age 10} & \multicolumn{2}{|c|}{ Age 11} & \multicolumn{2}{|c|}{ Age 12} & \multicolumn{2}{|c|}{ Age 13} & \multicolumn{2}{|c|}{ Age 14} \\
\hline & $\begin{array}{c}\text { Females } \\
(\% \\
\text { within } \\
\text { sex for } \\
\text { age) }\end{array}$ & $\begin{array}{c}\text { Males } \\
(\% \\
\text { within } \\
\text { sex for } \\
\text { age) }\end{array}$ & $\begin{array}{c}\text { Females } \\
(\% \\
\text { within } \\
\text { sex for } \\
\text { age) }\end{array}$ & $\begin{array}{c}\text { Males } \\
(\% \\
\text { within } \\
\text { sex for } \\
\text { age) }\end{array}$ & $\begin{array}{c}\text { Females } \\
(\% \\
\text { within } \\
\text { sex for } \\
\text { age) }\end{array}$ & $\begin{array}{l}\text { Males } \\
\text { (\% } \\
\text { within } \\
\text { sex for } \\
\text { age) }\end{array}$ & $\begin{array}{c}\text { Females } \\
\text { (\% } \\
\text { within } \\
\text { sex for } \\
\text { age) }\end{array}$ & $\begin{array}{l}\text { Males } \\
\text { (\% } \\
\text { within } \\
\text { sex for } \\
\text { age) }\end{array}$ & $\begin{array}{c}\text { Females } \\
(\% \\
\text { within } \\
\text { sex for } \\
\text { age) }\end{array}$ & $\begin{array}{c}\text { Males } \\
(\% \\
\text { within } \\
\text { sex for } \\
\text { age) }\end{array}$ \\
\hline \multicolumn{11}{|l|}{ Mainland } \\
\hline Arusha & * & 37.7 & * & * & * & 17.8 & 8.5 & * & * & * \\
\hline $\begin{array}{c}\text { Dar es } \\
\text { Salaam }\end{array}$ & * & 0 & * & * & * & 17 & * & * & * & * \\
\hline Dodoma & 9.7 & 34.3 & * & 12.5 & 18.8 & 28.4 & 11.8 & 30 & * & * \\
\hline Geita & 22.2 & 21.7 & 8.9 & 13.2 & 16.3 & 10.5 & 10.6 & 31 & 18.4 & 19.8 \\
\hline Iringa & * & 6.1 & * & 0 & 0 & 7.3 & 0 & * & 7.3 & 5.4 \\
\hline Kagera & 4.3 & 5.5 & * & * & 7.3 & * & 7 & * & 18.3 & * \\
\hline Katavi & 40.7 & 43.5 & 23.8 & * & 21.1 & * & 42 & 31.1 & * & * \\
\hline Kigoma & 8.4 & 5.6 & 1.6 & 10.2 & 8.1 & 16 & 12.4 & 10.9 & 7 & 19.1 \\
\hline Kilimanjaro & * & 4.6 & 6.5 & 0 & 0 & 3 & 3.4 & * & * & 14.1 \\
\hline Lindi & * & 20.6 & * & 12.4 & * & * & * & 30 & * & * \\
\hline Manyara & 11.8 & 17.7 & 25.7 & 7.4 & 4.3 & * & 5.1 & 19.2 & 25.2 & * \\
\hline Mara & 0 & 5.2 & 11.3 & 11.1 & 7.6 & 5.4 & 6.2 & * & 21.5 & * \\
\hline Mbeya & * & 8.2 & 11 & 25.8 & 10.6 & 4 & 17.4 & * & 19.9 & 42.6 \\
\hline Morogoro & * & 23 & 2.4 & * & * & * & * & * & * & * \\
\hline Mtwara & 4.6 & 10.6 & * & 3.3 & 0 & * & * & * & * & * \\
\hline Mwanza & * & 9.8 & 6.1 & 7.9 & 2.8 & 9 & 4.8 & * & 12.5 & 9.7 \\
\hline Njombe & * & 4 & 5.6 & 0 & * & 0 & 4.7 & 1.6 & * & * \\
\hline Pwani & * & 8.1 & * & * & 9.2 & * & $\star$ & $*$ & * & 12.5 \\
\hline Rukwa & * & 23.4 & 8.3 & 17.9 & 25.2 & * & 25.4 & * & * & 24.8 \\
\hline Ruvuma & 21.6 & 8.8 & 6.8 & 1.2 & * & 1.7 & 9.5 & 9.9 & * & 1.9 \\
\hline Shinyanga & * & 17.7 & * & $*$ & * & 20 & 25.6 & 10.2 & * & * \\
\hline Simiyu & 19.4 & 11.6 & 6.4 & 20.4 & 14.8 & 14.8 & 13.5 & 11.5 & 13.7 & * \\
\hline Singida & 13.6 & 13.3 & 8.2 & 1.2 & * & 25.4 & * & 20.5 & * & * \\
\hline Tabora & 25.6 & 26.5 & 5.9 & 35.7 & 21.1 & $*$ & 19.7 & 25.6 & 25.5 & 23.8 \\
\hline Tanga & 9.4 & 13 & * & * & 14.5 & 5.2 & 3.1 & * & * & 12.3 \\
\hline \multicolumn{11}{|l|}{ Zanzibar } \\
\hline $\begin{array}{l}\text { Kaskazini } \\
\text { Unguja }\end{array}$ & * & 9.2 & * & * & * & * & * & 11.8 & * & * \\
\hline $\begin{array}{l}\text { Kusini } \\
\text { Unguja }\end{array}$ & * & 0 & * & * & * & * & 0 & * & * & * \\
\hline $\begin{array}{c}\text { Mjini } \\
\text { Magharibi }\end{array}$ & * & 0 & * & * & * & * & * & * & * & * \\
\hline $\begin{array}{l}\text { Kaskazini } \\
\text { Pemba }\end{array}$ & 21.2 & 11.3 & * & * & 11.4 & 15.3 & * & * & * & * \\
\hline $\begin{array}{l}\text { Kusini } \\
\text { Pemba }\end{array}$ & 4.2 & 44 & 14.9 & * & * & * & * & * & * & * \\
\hline Mainland & 11 & 14 & 8.1 & 10 & 11 & 12.9 & 11.4 & 15.6 & 17.1 & 19.4 \\
\hline Zanzibar & 5.9 & 8.5 & 5.7 & 5.9 & 3.1 & 5.4 & 1.5 & 5.8 & 5.9 & 9.1 \\
\hline Urban & 0.9 & 0.9 & 2 & 1.2 & 1.8 & 6.5 & 8 & 6.1 & 11.6 & 6 \\
\hline Rural & 12.8 & 16.2 & 9.4 & 11.8 & 12.9 & 14.2 & 12 & 17.5 & 18.2 & 22.2 \\
\hline National & 10.8 & 13.8 & 8 & 9.9 & 10.7 & 12.7 & 11.1 & 15.3 & 16.7 & 19.1 \\
\hline
\end{tabular}




\begin{tabular}{|c|c|c|c|c|}
\hline \multicolumn{5}{|c|}{$\begin{array}{l}\text { Annex Table 8A: Females who are Illiterate (Unable to Read a Sentence), Percent (DHS } \\
\text { 2010) }\end{array}$} \\
\hline Region & $\begin{array}{l}\text { 15-19 year } \\
\text { olds (\% within } \\
\text { sex and age) }\end{array}$ & $\begin{array}{l}\text { 15-17 year } \\
\text { olds (\% within } \\
\text { sex and age) }\end{array}$ & $\begin{array}{l}\text { 18-19 year } \\
\text { olds (\% within } \\
\text { sex and age) }\end{array}$ & $\begin{array}{c}20-24 \text { year } \\
\text { olds (\% } \\
\text { within sex } \\
\text { and age) }\end{array}$ \\
\hline \multicolumn{5}{|l|}{ Mainland } \\
\hline Arusha & 5.7 & 2.6 & 11.3 & 31.5 \\
\hline Dar es Salaam & 5.8 & 4.1 & 9.5 & 14.6 \\
\hline Dodoma & 21.4 & 23.4 & * & 40.7 \\
\hline Iringa & 13.1 & 9.8 & 17.8 & 10.7 \\
\hline Kagera & 12.6 & 10 & 16.7 & 27.1 \\
\hline Kigoma & 9 & 10 & 6.6 & 28 \\
\hline Kilimanjaro & 1.4 & 0 & * & 18.4 \\
\hline Lindi & 20.6 & * & * & 34.5 \\
\hline Manyara & 10.2 & 3.4 & 21.5 & 34 \\
\hline Mara & 15.3 & 13.5 & 18.7 & 35.8 \\
\hline Mbeya & 23.7 & 26.8 & * & 31.3 \\
\hline Morogoro & 14.1 & 12.8 & 15.4 & 37 \\
\hline Mtwara & 13.1 & 9.3 & * & 23.2 \\
\hline Mwanza & 19.1 & 19.1 & 19.2 & 29.9 \\
\hline Pwani & 11.8 & 6.5 & * & 34.3 \\
\hline Rukwa & 27.1 & 27.2 & * & 36.5 \\
\hline Ruvuma & 11.3 & 7.4 & * & 19.3 \\
\hline Shinyanga & 30.7 & 32.8 & 27.9 & 34.7 \\
\hline Singida & 18.8 & 14.5 & * & 18.6 \\
\hline Tabora & 29.9 & 27.6 & 33.5 & 52.2 \\
\hline Tanga & 12.9 & 11.4 & * & 31.5 \\
\hline \multicolumn{5}{|l|}{ Zanzibar } \\
\hline Kaskazini Unguja & 11.8 & 8.9 & 16.4 & 15.1 \\
\hline Kusini Unguja & 3 & 1.8 & 4.8 & 6.3 \\
\hline Mjini Magharibi & 3.1 & 1 & 6.4 & 1.9 \\
\hline Kaskazini Pemba & 15.2 & 11.5 & 22.3 & 23.9 \\
\hline Kusini Pemba & 10.7 & 12 & 8.2 & 19.5 \\
\hline Mainland & 16.3 & 14.9 & 18.8 & 29.1 \\
\hline Zanzibar & 8.4 & 6.8 & 11.2 & 10.9 \\
\hline Urban & 4.9 & 3.5 & 7.3 & 14.9 \\
\hline Rural & 20.7 & 19.4 & 23.2 & 35.2 \\
\hline National & 16 & 14.7 & 18.5 & 28.5 \\
\hline
\end{tabular}




\begin{tabular}{|c|c|c|c|c|}
\hline \multicolumn{5}{|c|}{$\begin{array}{l}\text { Annex Table 8B: Males who are Illiterate (Unable to Read a Sentence), Percent } \\
\text { (DHS 2010) }\end{array}$} \\
\hline Region & $\begin{array}{l}\text { 15-19 year } \\
\text { olds (\% within } \\
\text { sex and age) }\end{array}$ & $\begin{array}{l}\text { 15-17 year } \\
\text { olds (\% within } \\
\text { sex and age) }\end{array}$ & $\begin{array}{c}\text { 18-19 year } \\
\text { olds (\% } \\
\text { within sex } \\
\text { and age) }\end{array}$ & $\begin{array}{c}20-24 \text { year } \\
\text { olds (\% } \\
\text { within sex } \\
\text { and age) }\end{array}$ \\
\hline \multicolumn{5}{|l|}{ Mainland } \\
\hline Arusha & * & * & * & * \\
\hline Dar es Salaam & 3.2 & * & * & * \\
\hline Dodoma & * & * & * & * \\
\hline Iringa & 10.4 & * & * & * \\
\hline Kagera & 29.7 & * & * & * \\
\hline Kigoma & * & * & * & * \\
\hline Kilimanjaro & 7.5 & * & * & * \\
\hline Lindi & * & * & * & * \\
\hline Manyara & * & * & * & * \\
\hline Mara & 10.5 & * & * & * \\
\hline Mbeya & 14.6 & * & * & * \\
\hline Morogoro & 13.7 & * & * & * \\
\hline Mtwara & * & * & * & * \\
\hline Mwanza & 27.1 & 34.6 & * & 21.2 \\
\hline Pwani & * & * & * & * \\
\hline Rukwa & * & * & * & * \\
\hline Ruvuma & * & * & * & * \\
\hline Shinyanga & 14.6 & * & * & * \\
\hline Singida & 13.6 & * & * & * \\
\hline Tabora & 22.8 & * & * & * \\
\hline Tanga & * & * & * & * \\
\hline \multicolumn{5}{|l|}{ Zanzibar } \\
\hline $\begin{array}{l}\text { Kaskazini } \\
\text { Unguja }\end{array}$ & 20.2 & 22.6 & * & * \\
\hline Kusini Unguja & 0 & * & * & 0 \\
\hline Mjini Magharibi & 3.5 & * & * & * \\
\hline $\begin{array}{l}\text { Kaskazini } \\
\text { Pemba }\end{array}$ & 5.4 & * & * & * \\
\hline Kusini Pemba & 0 & * & * & 0 \\
\hline Mainland & 15.7 & 17 & 13.7 & 19.9 \\
\hline Zanzibar & 6.8 & 7.5 & 5.8 & 3.6 \\
\hline Urban & 5.6 & 8.5 & 1.9 & 6.7 \\
\hline Rural & 18.7 & 19.1 & 18.1 & 23.9 \\
\hline National & 15.4 & 16.6 & 13.4 & 18.8 \\
\hline
\end{tabular}




\begin{tabular}{|c|c|c|}
\hline \multicolumn{3}{|c|}{$\begin{array}{l}\text { Annex Table 11: Percent of 10-14 year olds Not } \\
\text { in School and Not Living with Either Parent (DHS } \\
\text { 2010) }\end{array}$} \\
\hline Region & $\begin{array}{c}\text { Girls (\% within } \\
\text { sex and age) }\end{array}$ & $\begin{array}{l}\text { Boys (\% } \\
\text { within sex } \\
\text { and age) }\end{array}$ \\
\hline \multicolumn{3}{|l|}{ Mainland } \\
\hline Arusha & 9.9 & 1.8 \\
\hline Dar es Salaam & 9.8 & 3.2 \\
\hline Dodoma & 2.7 & 4.3 \\
\hline Iringa & 7.1 & 4.1 \\
\hline Kagera & 6.4 & 2.8 \\
\hline Kigoma & 1.2 & 1.5 \\
\hline Kilimanjaro & 0.6 & 1.5 \\
\hline Lindi & 3.2 & 9 \\
\hline Manyara & 3.8 & 2.3 \\
\hline Mara & 1.4 & 2.7 \\
\hline Mbeya & 7.6 & 3.5 \\
\hline Morogoro & 4.6 & 4.2 \\
\hline Mtwara & 6.9 & 3.1 \\
\hline Mwanza & 6.5 & 6.8 \\
\hline Pwani & 3.3 & 3.6 \\
\hline Rukwa & 7.7 & 3.3 \\
\hline Ruvuma & 2.6 & 1.8 \\
\hline Shinyanga & 5.9 & 8.1 \\
\hline Singida & 1.8 & 3.7 \\
\hline Tabora & 8.1 & 5.8 \\
\hline Tanga & 3.9 & 1.6 \\
\hline \multicolumn{3}{|l|}{ Zanzibar } \\
\hline $\begin{array}{l}\text { Kaskazini } \\
\text { Unguja }\end{array}$ & 2.3 & 1.4 \\
\hline Kusini Unguja & 0.9 & 0.8 \\
\hline Mjini Magharibi & 1 & 0 \\
\hline $\begin{array}{c}\text { Kaskazini } \\
\text { Pemba }\end{array}$ & 3.7 & 2.3 \\
\hline Kusini Pemba & 2.2 & 2.5 \\
\hline Mainland & 5.3 & 4 \\
\hline Zanzibar & 1.9 & 1.3 \\
\hline Urban & 8.1 & 3.1 \\
\hline Rural & 4.4 & 4.1 \\
\hline National & 5.2 & 3.9 \\
\hline
\end{tabular}




\begin{tabular}{|c|c|c|c|}
\hline \multicolumn{4}{|c|}{$\begin{array}{l}\text { Annex Table 12. Females Ages 15-24 Who are Illiterate (unable to read a } \\
\text { sentence) and Married Before Ages } 15 \text { and 18, Percent (DHS 2010) }\end{array}$} \\
\hline Region & $\begin{array}{l}\text { Among those } \\
\text { married before } \\
\text { age } 15 \text { (\% within } \\
\text { sex and age) }\end{array}$ & $\begin{array}{l}\text { Among those } \\
\text { married before } \\
\text { age } 18 \text { (\% within } \\
\text { sex and age) }\end{array}$ & $\begin{array}{c}\text { Among the never } \\
\text { married (\% } \\
\text { within sex and } \\
\text { age) }\end{array}$ \\
\hline \multicolumn{4}{|l|}{ Mainland } \\
\hline Arusha & * & * & 6.3 \\
\hline Dar es Salaam & * & 23.7 & 5.8 \\
\hline Dodoma & * & 42.1 & 19.9 \\
\hline Iringa & * & * & 13 \\
\hline Kagera & * & 27.1 & 11.1 \\
\hline Kigoma & * & * & 8.9 \\
\hline Kilimanjaro & * & * & 3.1 \\
\hline Lindi & * & 35.9 & 16.5 \\
\hline Manyara & * & * & 6.8 \\
\hline Mara & * & 28.8 & 16.9 \\
\hline Mbeya & * & 53.9 & 10.9 \\
\hline Morogoro & * & 64.9 & 8.2 \\
\hline Mtwara & * & * & 11.8 \\
\hline Mwanza & * & 44 & 16.2 \\
\hline Pwani & * & 54.1 & 13.6 \\
\hline Rukwa & * & 43.5 & 23 \\
\hline Ruvuma & * & 24.5 & 6.6 \\
\hline Shinyanga & * & 45.6 & 25.3 \\
\hline Singida & * & 34.2 & 15.4 \\
\hline Tabora & * & 58.2 & 19.8 \\
\hline Tanga & * & * & 10.5 \\
\hline \multicolumn{4}{|l|}{ Zanzibar } \\
\hline Kaskazini Unguja & * & 32.4 & 7.7 \\
\hline Kusini Unguja & * & * & 1.6 \\
\hline Mjini Magharibi & * & * & 2.2 \\
\hline Kaskazini Pemba & * & 42 & 12.8 \\
\hline Kusini Pemba & * & 47.9 & 8.5 \\
\hline Mainland & 58.8 & 42.5 & 12.3 \\
\hline Zanzibar & 25.3 & 29 & 6.1 \\
\hline Urban & * & 25.9 & 4.9 \\
\hline Rural & 64 & 45.8 & 16.3 \\
\hline National & 58.4 & 42.2 & 12 \\
\hline
\end{tabular}




\begin{tabular}{|c|c|c|c|c|}
\hline Region & $\begin{array}{l}\text { Ever-married } \\
\text { with a child } \\
\text { (\% within sex } \\
\text { and age) }\end{array}$ & $\begin{array}{l}\text { Never- } \\
\text { married with } \\
\text { a child (\% } \\
\text { within sex } \\
\text { and age) }\end{array}$ & $\begin{array}{c}\text { Ever-married } \\
\text { no child (\% } \\
\text { within sex } \\
\text { and age) }\end{array}$ & $\begin{array}{c}\text { Never- } \\
\text { married no } \\
\text { child (\% } \\
\text { within sex } \\
\text { and age) }\end{array}$ \\
\hline \multicolumn{5}{|l|}{ Mainland } \\
\hline Arusha & * & * & * & 62.5 \\
\hline Dar es Salaam & * & * & * & 49.4 \\
\hline Dodoma & * & * & * & 50.2 \\
\hline Iringa & * & * & * & 53.7 \\
\hline Kagera & * & * & * & 66 \\
\hline Kigoma & * & * & * & 48.2 \\
\hline Kilimanjaro & * & * & * & 81.8 \\
\hline Lindi & * & * & * & 28.7 \\
\hline Manyara & * & * & * & 46.2 \\
\hline Mara & * & * & * & 42.1 \\
\hline Mbeya & * & * & * & 47.3 \\
\hline Morogoro & * & * & * & 64.8 \\
\hline Mtwara & * & * & * & 49.9 \\
\hline Mwanza & * & * & * & 47.9 \\
\hline Pwani & * & * & * & 49.9 \\
\hline Rukwa & * & * & * & 36.6 \\
\hline Ruvuma & * & * & * & 50.7 \\
\hline Shinyanga & * & * & * & 45.2 \\
\hline Singida & * & * & * & 49.1 \\
\hline Tabora & * & * & * & 44.1 \\
\hline Tanga & * & * & * & 53.9 \\
\hline \multicolumn{5}{|l|}{ Zanzibar } \\
\hline $\begin{array}{c}\text { Kaskazini } \\
\text { Unguja }\end{array}$ & * & * & * & 75.1 \\
\hline Kusini Unguja & * & * & * & 66.3 \\
\hline Mjini Magharibi & * & * & * & 72.3 \\
\hline $\begin{array}{c}\text { Kaskazini } \\
\text { Pemba }\end{array}$ & * & * & * & 74.8 \\
\hline Kusini Pemba & * & * & * & 76.4 \\
\hline Mainland & 0 & 8 & 1 & 52.4 \\
\hline Zanzibar & 0 & * & * & 73.6 \\
\hline Urban & 0 & 23.4 & * & 59.3 \\
\hline Rural & 0 & 0 & 0.1 & 50.4 \\
\hline National & 0 & 7.9 & 1.1 & 53.4 \\
\hline
\end{tabular}




\begin{tabular}{|c|c|c|c|c|}
\hline \multicolumn{5}{|c|}{$\begin{array}{l}\text { Annex Table 15: Marriage by Age 15-18, Among Females Aged 20-24, } \\
\text { Percent (DHS 2010) }\end{array}$} \\
\hline Region & $\begin{array}{c}\text { \% Married } \\
\text { before Age } \\
15\end{array}$ & $\begin{array}{c}\text { \% Married } \\
\text { before Age } \\
16\end{array}$ & $\begin{array}{c}\text { \% Married } \\
\text { before Age } \\
17\end{array}$ & $\begin{array}{c}\text { \% Married } \\
\text { before Age } \\
18\end{array}$ \\
\hline \multicolumn{5}{|l|}{ Mainlaind } \\
\hline Arusha & 7.2 & 14.7 & 22 & 27.3 \\
\hline Dar es Salaam & 5.7 & 12.4 & 15.4 & 18.6 \\
\hline Dodoma & 11.3 & 23 & 39.6 & 51.1 \\
\hline Iringa & 0 & 0 & 2.3 & 8.2 \\
\hline Kagera & 4.1 & 9.1 & 21 & 36.4 \\
\hline Kigoma & 6.4 & 13 & 21.7 & 25.5 \\
\hline Kilimanjaro & 6.4 & 16.2 & 21.4 & 26.6 \\
\hline Lindi & 12.9 & 24.7 & 35.7 & 47.7 \\
\hline Manyara & 8.3 & 10.2 & 20.7 & 33.7 \\
\hline Mara & 11.9 & 21.9 & 45.8 & 54.5 \\
\hline Mbeya & 7.6 & 17.8 & 30.3 & 45 \\
\hline Morogoro & 11 & 22.3 & 27.4 & 42.2 \\
\hline Mtwara & 2.1 & 13.1 & 29.2 & 35.2 \\
\hline Mwanza & 7.4 & 12.1 & 20.9 & 37.4 \\
\hline Pwani & 9.2 & 15.7 & 26.4 & 32.5 \\
\hline Rukwa & 11.4 & 16.6 & 28.9 & 40 \\
\hline Ruvuma & 4.4 & 13.5 & 24 & 39.2 \\
\hline Shinyanga & 3.4 & 17.5 & 34.9 & 58.8 \\
\hline Singida & 0 & 11.7 & 26.4 & 41.9 \\
\hline Tabora & 11.6 & 29.1 & 45.9 & 58.3 \\
\hline Tanga & 9.1 & 14.6 & 22.7 & 29.4 \\
\hline \multicolumn{5}{|l|}{ Zanzibar } \\
\hline $\begin{array}{l}\text { Kaskazini } \\
\text { Unguja }\end{array}$ & 3.3 & 5.4 & 17 & 23.6 \\
\hline Kusini Unguja & 3.3 & 7.4 & 12.9 & 18.6 \\
\hline $\begin{array}{c}\text { Mjini } \\
\text { Magharibi }\end{array}$ & 0 & 5.6 & 9.7 & 14 \\
\hline $\begin{array}{l}\text { Kaskazini } \\
\text { Pemba }\end{array}$ & 3.1 & 6.5 & 12.8 & 25.4 \\
\hline Kusini Pemba & 7 & 14 & 19.8 & 25.7 \\
\hline Mainland & 6.8 & 15.3 & 26.1 & 37.4 \\
\hline Zanzibar & 2.5 & 7.3 & 13.3 & 19.7 \\
\hline Urban & 4.2 & 9.9 & 16.5 & 22.5 \\
\hline Rural & 7.8 & 17.6 & 30.1 & 43.9 \\
\hline National & 6.6 & 15.1 & 25.6 & 36.9 \\
\hline
\end{tabular}


Annex Table 16A-1: Sexual Initiation Before Ages 15 and 18, Among Females Ages 20-24, Percent (DHS 2010)

\begin{tabular}{|c|c|c|c|}
\hline Region & $\begin{array}{l}\text { Had sex } \\
\text { before the } \\
\text { age of } 15^{a}\end{array}$ & $\begin{array}{c}\text { Had sex } \\
\text { before the } \\
\text { age of } 18^{a}\end{array}$ & $\begin{array}{c}\text { First sexual } \\
\text { experience at } \\
\text { marriage }\end{array}$ \\
\hline \multicolumn{4}{|l|}{ Mainlaind } \\
\hline Arusha & 9.9 & 43.3 & 41.9 \\
\hline Dar es Salaam & 8.5 & 48.3 & 10 \\
\hline Dodoma & 18.2 & 67 & 48.8 \\
\hline Iringa & 4.6 & 25.6 & 15.7 \\
\hline Kagera & 5.5 & 49.2 & 38.7 \\
\hline Kigoma & 16.3 & 40.8 & 33.5 \\
\hline Kilimanjaro & 12.9 & 34 & 44.2 \\
\hline Lindi & 31.7 & 83 & 18.6 \\
\hline Manyara & 11.5 & 45.8 & 41.8 \\
\hline Mara & 24.4 & 77.5 & 27.5 \\
\hline Mbeya & 9.7 & 55.5 & 48 \\
\hline Morogoro & 21.5 & 68.8 & 10.4 \\
\hline Mtwara & 27.5 & 71.9 & 8.3 \\
\hline Mwanza & 21.3 & 69.4 & 15.9 \\
\hline Pwani & 13.4 & 64.3 & 9 \\
\hline Rukwa & 12.6 & 47.9 & 63.4 \\
\hline Ruvuma & 19 & 79.1 & 9.5 \\
\hline Shinyanga & 11.4 & 78.5 & 55.5 \\
\hline Singida & 4.9 & 55.1 & 49.3 \\
\hline Tabora & 27.9 & 80.2 & 41.8 \\
\hline Tanga & 9.1 & 48.5 & 34.6 \\
\hline \multicolumn{4}{|l|}{ Zanzibar } \\
\hline $\begin{array}{c}\text { Kaskazini } \\
\text { Unguja }\end{array}$ & 3.3 & 23.3 & 54.1 \\
\hline Kusini Unguja & 5.9 & 25 & 32.3 \\
\hline $\begin{array}{c}\text { Mjini } \\
\text { Magharibi }\end{array}$ & 2.2 & 20 & 29.2 \\
\hline $\begin{array}{c}\text { Kaskazini } \\
\text { Pemba }\end{array}$ & 2.1 & 25.4 & 49.2 \\
\hline Kusini Pemba & 7 & 25.7 & 46.7 \\
\hline Mainland & 14.5 & 58.9 & 31.5 \\
\hline Zanzibar & 3.5 & 22.8 & 39.7 \\
\hline Urban & 9.4 & 47.9 & 17.4 \\
\hline Rural & 16.4 & 62.5 & 38.8 \\
\hline National & 14.1 & 57.7 & 31.8 \\
\hline
\end{tabular}


Annex Table 16B: Sexual Initiation Before Ages 15 and 18, Among Females Ages 20-24, Percent (THMIS 2011-2012)

\begin{tabular}{|c|c|c|}
\hline Region & $\begin{array}{c}\text { Had sex before the } \\
\text { age of } 15^{a}\end{array}$ & $\begin{array}{c}\text { Had sex before the } \\
\text { age of } 18^{a}\end{array}$ \\
\hline \multicolumn{3}{|l|}{ Mainland } \\
\hline Arusha & 3.9 & 55.6 \\
\hline Dar es Salaam & 4 & 28.7 \\
\hline Dodoma & 27.7 & 53.4 \\
\hline Geita & 13.5 & 72.7 \\
\hline Iringa & 8.7 & 20.2 \\
\hline Kagera & 6.4 & 51.5 \\
\hline Katavi & 16.5 & 73.3 \\
\hline Kigoma & 3.9 & 30.1 \\
\hline Kilimanjaro & 1.5 & 29.9 \\
\hline Lindi & 14.2 & 70.7 \\
\hline Manyara & 5.8 & 35 \\
\hline Mara & 5.7 & 71.3 \\
\hline Mbeya & 2.2 & 34.3 \\
\hline Morogoro & 4.7 & 73.8 \\
\hline Mtwara & 28.6 & 80.3 \\
\hline Mwanza & 9.5 & 51.5 \\
\hline Njombe & 3.4 & 36 \\
\hline Pwani & 4.9 & 51.6 \\
\hline Rukwa & 20.3 & 60.4 \\
\hline Ruvuma & 4.8 & 40.5 \\
\hline Shinyanga & 13.1 & 73.7 \\
\hline Simiyu & 8.2 & 65.3 \\
\hline Singida & 3.7 & 22.1 \\
\hline Tabora & 20 & 62.3 \\
\hline Tanga & 23.5 & 47 \\
\hline \multicolumn{3}{|l|}{ Zanzibar } \\
\hline Kaskazini & 4.4 & 19.4 \\
\hline Kusini & 4.5 & 29.1 \\
\hline Mjini magharibi & 3.3 & 16.5 \\
\hline Kaskazini Pemba & 8.1 & 31.3 \\
\hline Kusini pemba & 2.9 & 22.5 \\
\hline Mainland & 9.5 & 49.4 \\
\hline Zanzibar & 4 & 20.1 \\
\hline Urban & 5.3 & 37.8 \\
\hline \begin{tabular}{|l|} 
Rural \\
\end{tabular} & 10.8 & 52.1 \\
\hline National & 9.3 & 48.2 \\
\hline
\end{tabular}




\begin{tabular}{|c|c|c|c|}
\hline \multicolumn{4}{|c|}{$\begin{array}{c}\text { Annex Table 18: Percent of Females Who Have Ever Been Pregnant, by Specific } \\
\text { Year of Age (DHS 2010) }\end{array}$} \\
\hline Age & Region & $\begin{array}{c}\text { Never been pregnant } \\
\text { (\% within sex and } \\
\text { age) }\end{array}$ & $\begin{array}{c}\text { Ever been pregnant } \\
\text { (\% within sex and } \\
\text { age) }\end{array}$ \\
\hline \multirow[t]{5}{*}{ Age 15} & Mainland & 94.4 & 5.6 \\
\hline & Zanzibar & 100 & 0 \\
\hline & Urban & 98.8 & 1.2 \\
\hline & Rural & 92.8 & 7.2 \\
\hline & National & 94.6 & 5.4 \\
\hline \multirow[t]{5}{*}{ Age 16} & Mainland & 87.2 & 12.8 \\
\hline & Zanzibar & 98.1 & 1.9 \\
\hline & Urban & 87.3 & 12.7 \\
\hline & Rural & 87.6 & 12.4 \\
\hline & National & 87.5 & 12.5 \\
\hline \multirow{5}{*}{ Age 17} & Mainland & 78.1 & 21.9 \\
\hline & Zanzibar & 96.6 & 3.4 \\
\hline & Urban & 88.2 & 11.8 \\
\hline & Rural & 74.2 & 25.8 \\
\hline & National & 78.8 & 21.2 \\
\hline \multirow[t]{5}{*}{ Age 18} & Mainland & 59.3 & 40.7 \\
\hline & Zanzibar & 89.5 & 10.5 \\
\hline & Urban & 74 & 26 \\
\hline & Rural & 54.6 & 45.4 \\
\hline & National & 60.5 & 39.5 \\
\hline \multirow{5}{*}{ Age 19} & Mainland & 53.7 & 46.3 \\
\hline & Zanzibar & 79.7 & 20.3 \\
\hline & Urban & 73.2 & 26.8 \\
\hline & Rural & 47.3 & 52.7 \\
\hline & National & 54.7 & 45.3 \\
\hline \multirow[t]{5}{*}{ Age 20} & Mainland & 35.3 & 64.7 \\
\hline & Zanzibar & 62.3 & 37.7 \\
\hline & Urban & 57.1 & 42.9 \\
\hline & Rural & 28.3 & 71.7 \\
\hline & National & 36.3 & 63.7 \\
\hline \multirow[t]{5}{*}{ Age 21} & Mainland & 26.6 & 73.4 \\
\hline & Zanzibar & 69.1 & 30.9 \\
\hline & Urban & 39.4 & 60.6 \\
\hline & Rural & 20.9 & 79.1 \\
\hline & National & 27.9 & 72.1 \\
\hline \multirow[t]{5}{*}{ Age 22} & Mainland & 12.2 & 87.8 \\
\hline & Zanzibar & 63.6 & 36.4 \\
\hline & Urban & 27.9 & 72.1 \\
\hline & Rural & 8.2 & 91.8 \\
\hline & National & 14.3 & 85.7 \\
\hline \multirow[t]{5}{*}{ Age 23} & Mainland & 16 & 84 \\
\hline & Zanzibar & 45.7 & 54.3 \\
\hline & Urban & 32.2 & 67.8 \\
\hline & Rural & 8 & 92 \\
\hline & National & 16.7 & 83.3 \\
\hline \multirow[t]{5}{*}{ Age 24} & Mainland & 8.2 & 91.8 \\
\hline & Zanzibar & 30.9 & 69.1 \\
\hline & Urban & 15.2 & 84.8 \\
\hline & Rural & 5.9 & 94.1 \\
\hline & National & 9 & 91 \\
\hline
\end{tabular}

\footnotetext{
* Includes those currently pregnant
} 


\begin{tabular}{|c|c|c|c|}
\hline \multicolumn{4}{|c|}{$\begin{array}{l}\text { Annex Table 19: Percent of Females Ages 15-17 Ever Pregnan } \\
\text { by Household Wealth Quintile (DHS 2010) }\end{array}$} \\
\hline $\begin{array}{c}\text { Household } \\
\text { Wealth } \\
\text { Quintile }\end{array}$ & Region & $\begin{array}{l}\% \text { Never } \\
\text { pregnant }\end{array}$ & $\begin{array}{l}\text { \% Ever } \\
\text { pregnant }\end{array}$ \\
\hline \multirow[t]{5}{*}{ Lowest } & Urban & * & * \\
\hline & Rural & 86.3 & 13.7 \\
\hline & Mainland & 86.6 & 13.4 \\
\hline & Zanzibar & * & * \\
\hline & National & 86.8 & 13.2 \\
\hline \multirow[t]{5}{*}{ Second } & Urban & * & * \\
\hline & Rural & 80.3 & 19.7 \\
\hline & Mainland & 80.2 & 19.8 \\
\hline & Zanzibar & 98.6 & 1.4 \\
\hline & National & 80.6 & 19.4 \\
\hline \multirow[t]{5}{*}{ Middle } & Urban & * & * \\
\hline & Rural & 84.2 & 15.8 \\
\hline & Mainland & 84.4 & 15.6 \\
\hline & Zanzibar & 95.3 & 4.7 \\
\hline & National & 84.7 & 15.3 \\
\hline \multirow[t]{5}{*}{ Fourth } & Urban & 85 & 15 \\
\hline & Rural & 90 & 10 \\
\hline & Mainland & 88.2 & 11.8 \\
\hline & Zanzibar & 98.1 & 1.9 \\
\hline & National & 88.6 & 11.4 \\
\hline \multirow[t]{5}{*}{ Highest } & Urban & 93.2 & 6.8 \\
\hline & Rural & 90 & 10 \\
\hline & Mainland & 92.2 & 7.8 \\
\hline & Zanzibar & 98.7 & 1.3 \\
\hline & National & 92.6 & 7.4 \\
\hline
\end{tabular}


Annex Table 21: Age Difference Between Woman and Current Husband/Cohabitating Partnera, Among Females Ages 15-24, Percent (THMIS 2011-2012)

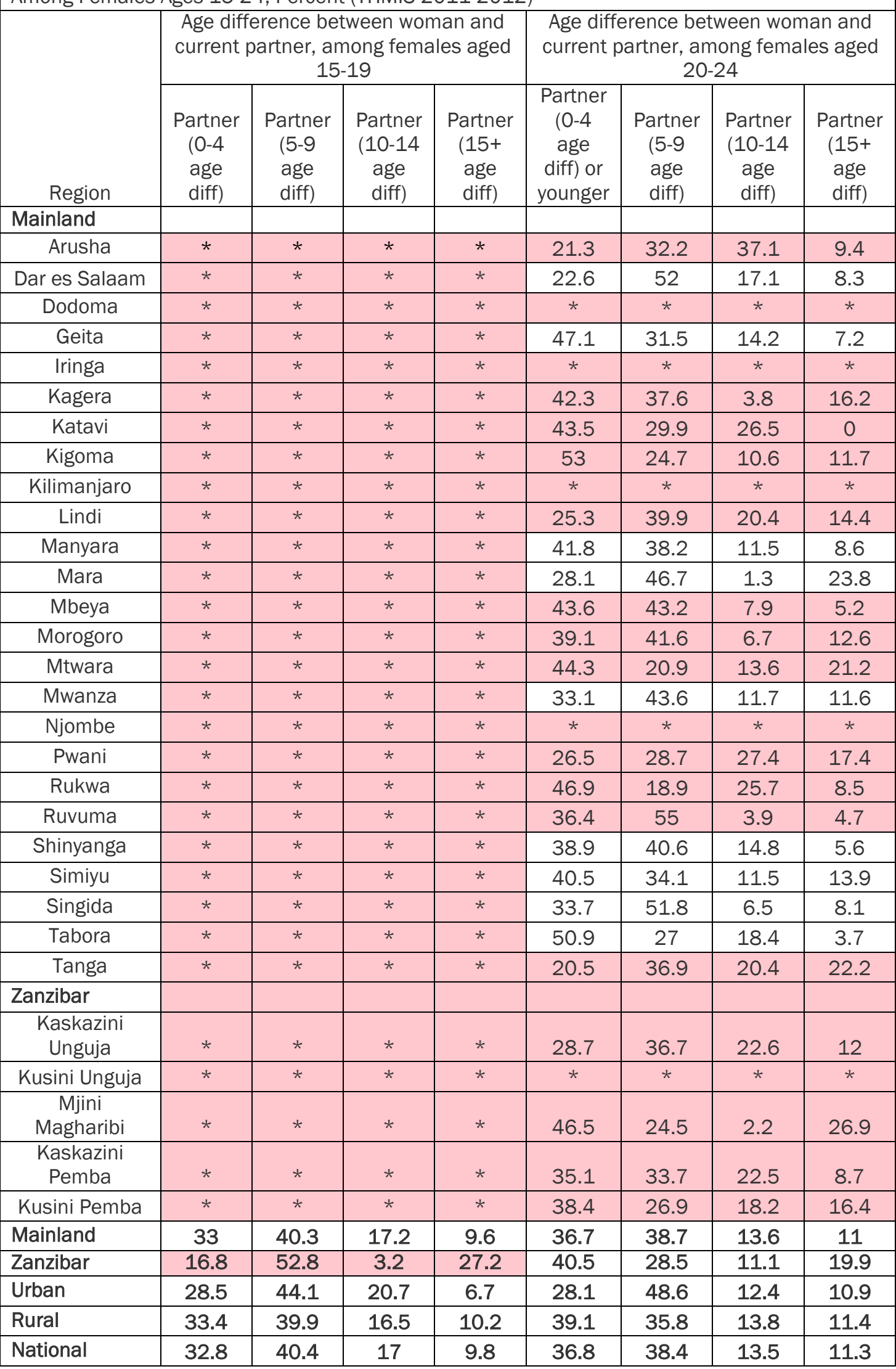

Notes: Read the first column of data as "Percent of 15-19 year old females with a husband/cohabitating partner who is the same age as she or within 4 years of her age," using 2011-12 THMIS; alncludes sexually experienced females only. 
Annex Table 22A: Percent of Females Ages 15-24 Who Agree It Is Acceptable for Husband to Beat Wife (DHS 2010)

\begin{tabular}{|c|c|c|c|c|c|c|c|}
\hline Region & $\begin{array}{l}\text { If wife } \\
\text { goes out } \\
\text { without } \\
\text { telling } \\
\text { husband }\end{array}$ & $\begin{array}{l}\text { If wife } \\
\text { neglects } \\
\text { children }\end{array}$ & $\begin{array}{l}\text { If wife } \\
\text { argues } \\
\text { with } \\
\text { husband }\end{array}$ & $\begin{array}{l}\text { If wife } \\
\text { refuses } \\
\text { to have } \\
\text { sex with } \\
\text { husband }\end{array}$ & $\begin{array}{l}\text { If wife } \\
\text { burns } \\
\text { the } \\
\text { food }\end{array}$ & $\begin{array}{l}\text { Percent } \\
\text { who } \\
\text { said yes } \\
\text { to at } \\
\text { least } \\
\text { one } \\
\text { reason }\end{array}$ & $\begin{array}{l}\text { Agreed } \\
\text { with all } \\
\text { five } \\
\text { reasons }\end{array}$ \\
\hline \multicolumn{8}{|l|}{ Mainland } \\
\hline Arusha & 31.8 & 51.1 & 35.6 & 23.5 & 15.8 & 54.8 & 14.9 \\
\hline Dar es Salaam & 21 & 41.3 & 21.4 & 9.4 & 7 & 34.2 & 4.3 \\
\hline Dodoma & 49.7 & 25.3 & 56.3 & 39.3 & 39.3 & 66.8 & 27.3 \\
\hline Iringa & 14.5 & 28.2 & 28.3 & 17.6 & 15.2 & 46.4 & 8.5 \\
\hline Kagera & 47.3 & 43.1 & 56.4 & 34.8 & 36.2 & 81.7 & 15 \\
\hline Kigoma & 53.1 & 53.3 & 58 & 47.6 & 35.2 & 80.9 & 20.1 \\
\hline Kilimanjaro & 21.8 & 22.2 & 28.3 & 13.4 & 6.5 & 37.6 & 3.9 \\
\hline Lindi & 39.4 & 38.1 & 42.9 & 35.2 & 20 & 56.8 & 16.5 \\
\hline Manyara & 27.3 & 22.7 & 23.8 & 21.4 & 8.5 & 39.7 & 10.1 \\
\hline Mara & 59.6 & 50.9 & 60 & 52 & 35.4 & 75.9 & 22.7 \\
\hline Mbeya & 30.7 & 32.1 & 36.3 & 26 & 8.2 & 56.7 & 4 \\
\hline Morogoro & 41.5 & 33.5 & 48.1 & 26.9 & 18 & 60.1 & 9.6 \\
\hline Mtwara & 23 & 38 & 22.9 & 19.8 & 9 & 34.3 & 7.5 \\
\hline Mwanza & 44.2 & 34.6 & 44 & 29.5 & 20.1 & 67.3 & 11.9 \\
\hline Pwani & 48.6 & 22 & 52.2 & 25.9 & 18 & 66.2 & 13.6 \\
\hline Rukwa & 30.7 & 70.1 & 33.6 & 31.1 & 9.8 & 62 & 5.8 \\
\hline Ruvuma & 50 & 46.7 & 45.7 & 39.6 & 22 & 64.1 & 20.1 \\
\hline Shinyanga & 20.4 & 60.6 & 27.3 & 14.9 & 10 & 38.6 & 5.1 \\
\hline Singida & 35.9 & 31.6 & 43.6 & 24.6 & 21.4 & 50.4 & 13.8 \\
\hline Tabora & 44.5 & 27.8 & 52.2 & 26 & 8.8 & 68.1 & 7.9 \\
\hline Tanga & 31.1 & 23.5 & 33.1 & 14.7 & 8.5 & 45.1 & 3.3 \\
\hline \multicolumn{8}{|l|}{ Zanzibar } \\
\hline $\begin{array}{c}\text { Kaskazini } \\
\text { Unguja }\end{array}$ & 36.4 & 9.3 & 29.2 & 24.5 & 5.8 & 49.5 & 5.7 \\
\hline Kusini Unguja & 28.1 & 13.6 & 18.7 & 14.7 & 7.2 & 40.2 & 4.7 \\
\hline $\begin{array}{c}\text { Mjini } \\
\text { Magharibi }\end{array}$ & 22.7 & 20.7 & 17.2 & 12.5 & 1.7 & 32.1 & 1.4 \\
\hline $\begin{array}{l}\text { Kaskazini } \\
\text { Pemba }\end{array}$ & 10.9 & 45.7 & 6.6 & 8 & 5.2 & 11.7 & 5.6 \\
\hline Kusini Pemba & 18.1 & 63.7 & 12 & 12.6 & 8.3 & 21.8 & 7.6 \\
\hline Mainland & 35.4 & 39.6 & 39.6 & 25.8 & 17.4 & 56.2 & 10.8 \\
\hline Zanzibar & 22.4 & 18.7 & 16.4 & 13.8 & 4.7 & 29.8 & 4.3 \\
\hline Urban & 27.4 & 32.7 & 32.1 & 16.3 & 10.2 & 46.1 & 6.2 \\
\hline Rural & 38.3 & 41.7 & 41.9 & 29.5 & 20 & 59.5 & 12.7 \\
\hline National & 34.9 & 38.9 & 38.8 & 25.4 & 17 & 55.3 & 10.6 \\
\hline
\end{tabular}




\begin{tabular}{|c|c|c|c|c|c|c|c|}
\hline \multicolumn{8}{|c|}{$\begin{array}{l}\text { Annex Table 22B: Percent of Males Ages 15-24 Who Agree It Is Acceptable for Husband to } \\
\text { Beat Wife (DHS 2010) }\end{array}$} \\
\hline Region & $\begin{array}{l}\text { If wife } \\
\text { goes out } \\
\text { without } \\
\text { telling } \\
\text { husband }\end{array}$ & $\begin{array}{c}\text { If wife } \\
\text { neglects } \\
\text { children }\end{array}$ & $\begin{array}{l}\text { If wife } \\
\text { argues } \\
\text { with } \\
\text { husband }\end{array}$ & $\begin{array}{l}\text { If wife } \\
\text { refuses } \\
\text { to have } \\
\text { sex with } \\
\text { husband }\end{array}$ & $\begin{array}{l}\text { If wife } \\
\text { burns } \\
\text { the } \\
\text { food }\end{array}$ & $\begin{array}{l}\text { Percent } \\
\text { who } \\
\text { said yes } \\
\text { to at } \\
\text { least } \\
\text { one } \\
\text { reason }\end{array}$ & $\begin{array}{l}\text { Agreed } \\
\text { with all } \\
\text { five } \\
\text { reasons }\end{array}$ \\
\hline \multicolumn{8}{|l|}{ Mainland } \\
\hline Arusha & * & * & * & * & * & * & * \\
\hline Dar es Salaam & 2.9 & 11.8 & 2 & 0.9 & 2 & 22.4 & 0 \\
\hline Dodoma & 12.6 & 22.2 & 16.7 & 16.3 & 3.4 & 28.6 & 3.4 \\
\hline Iringa & 7.1 & 22.2 & 8.1 & 4.6 & 0 & * & * \\
\hline Kagera & 43.3 & 62.4 & 31.9 & 22.1 & 21.2 & 86.6 & 7.9 \\
\hline Kigoma & 23.2 & 43.6 & 14 & 13.4 & 0 & * & * \\
\hline Kilimanjaro & 27.8 & 25.2 & 21.7 & 0 & 0 & 41.5 & 0 \\
\hline Lindi & * & * & * & * & * & * & * \\
\hline Manyara & 37.3 & 33.5 & 26.4 & 8.4 & 5.1 & * & * \\
\hline Mara & 31.8 & 39 & 47.4 & 18.2 & 14.8 & 58.8 & 3.3 \\
\hline Mbeya & 9.9 & 18.5 & 11.2 & 4 & 0 & * & * \\
\hline Morogoro & 26.6 & 39.9 & 22.9 & 4.2 & 0 & * & * \\
\hline Mtwara & 11.3 & 14.6 & 12.1 & 5.7 & 8.7 & 17.2 & 5.7 \\
\hline Mwanza & 28.7 & 24.6 & 33.8 & 9.4 & 9.8 & 49.3 & 3.1 \\
\hline Pwani & 52.7 & 46.4 & 45 & 17.2 & 7.3 & * & * \\
\hline Rukwa & 12.8 & 23 & 23.1 & 20 & 7.3 & 37.8 & 5.4 \\
\hline Ruvuma & 20.7 & 25.9 & 15.5 & 12.7 & 2 & 48.4 & 0 \\
\hline Shinyanga & 28.1 & 16.3 & 29 & 21.3 & 15.4 & 42.3 & 7.1 \\
\hline Singida & 15.3 & 14.3 & 0.8 & 2.6 & 3.3 & * & * \\
\hline Tabora & 28.5 & 19.6 & 19.5 & 5.8 & 4.1 & 48.5 & 3.1 \\
\hline Tanga & * & * & * & * & * & * & * \\
\hline \multicolumn{8}{|l|}{ Zanzibar } \\
\hline $\begin{array}{l}\text { Kaskazini } \\
\text { Unguja }\end{array}$ & 25.6 & 17.5 & 16.6 & 17.4 & 2.2 & 52.1 & 3.9 \\
\hline Kusini Unguja & 3.3 & 5.9 & 1.6 & 3.3 & 0 & 13.5 & 0 \\
\hline $\begin{array}{l}\text { Mjini } \\
\text { Magharibi }\end{array}$ & 16 & 14.3 & 12.4 & 14 & 4.1 & 27.1 & 2.1 \\
\hline $\begin{array}{c}\text { Kaskazini } \\
\text { Pemba }\end{array}$ & 15.1 & 14.5 & 12.3 & 15 & 4.3 & 21 & 4.4 \\
\hline Kusini Pemba & 14.8 & 16.4 & 9.4 & 16.9 & 5.6 & 35.1 & 6.1 \\
\hline Mainland & 24.1 & 27.9 & 22.6 & 11.3 & 6.6 & 50.7 & 3.3 \\
\hline Zanzibar & 15.5 & 14 & 11.1 & 13.7 & 3.5 & 28.7 & 3.1 \\
\hline Urban & 12.5 & 19.5 & 12.3 & 4.8 & 1.3 & 35 & 0.1 \\
\hline Rural & 28 & 30.4 & 25.9 & 13.8 & 8.4 & 55.4 & 4.6 \\
\hline National & 23.8 & 27.5 & 22.3 & 11.4 & 6.5 & 50 & 3.3 \\
\hline
\end{tabular}


Annex Table 25B-1: VACS 2009, Among Females Ages 15-24 Who Ever Experienced Coerced Sex, Percent Who Report Specific Persons Committing First Forced Sex

\begin{tabular}{|c|c|c|c|c|c|c|c|c|}
\hline \multirow[b]{2}{*}{ Region } & \multicolumn{4}{|c|}{ Partner (Spouse/ boyfriend) } & \multicolumn{4}{|c|}{ Someone Other than Partner } \\
\hline & $15-17$ years & 18-19 years & 15-19 years & 20-24 years & $15-17$ years & 18-19 years & $15-19$ years & 20-24 years \\
\hline Mainland & * & * & 52.1 & 66.4 & * & * & 37.6 & 26.7 \\
\hline Zanzibar & * & * & * & * & * & * & * & * \\
\hline National & * & * & 52.1 & 66.3 & * & * & 37.6 & 26.8 \\
\hline
\end{tabular}

Annex Table 25B-2: VACS 2009, Among Males Ages 15-24 Who Ever Experienced Coerced Sex, Percent Who Report Specific Persons Committing First Forced Sex

\begin{tabular}{|c|c|c|c|c|c|c|c|c|}
\hline \multirow[b]{2}{*}{ Region } & \multicolumn{4}{|c|}{ Partner (Spouse/ boyfriend) } & \multicolumn{4}{|c|}{ Someone Other than Partner } \\
\hline & $15-17$ years & 18-19 years & $15-19$ years & 20-24 years & 15-17 years & 18-19 years & 15-19 years & 20-24 years \\
\hline Mainland & * & * & * & * & * & * & * & * \\
\hline Zanzibar & * & * & * & * & * & * & * & * \\
\hline National & * & * & * & * & * & * & * & * \\
\hline
\end{tabular}




\begin{tabular}{|c|c|c|c|c|}
\hline Region & $15-17$ years & $18-19$ years & $15-19$ years & 20-24 years \\
\hline \multicolumn{5}{|l|}{ Mainland } \\
\hline Arusha & 15.1 & 7.3 & 12.5 & 18.2 \\
\hline Dar es Salaam & 13.7 & 9.9 & 12.5 & 35.7 \\
\hline Dodoma & 43.6 & * & 48.7 & 59.9 \\
\hline Iringa & 23.6 & 29.1 & 26.2 & 26 \\
\hline Kagera & 33.9 & 40.4 & 36.5 & 55.1 \\
\hline Kigoma & 25 & 7.8 & 20 & 39.5 \\
\hline Kilimanjaro & 4.4 & * & 5.9 & 32 \\
\hline Lindi & * & * & 14.8 & 24.8 \\
\hline Manyara & 3 & 0 & 2.1 & 20.3 \\
\hline Mara & 41.2 & 39.8 & 40.7 & 73.5 \\
\hline Mbeya & 22.5 & * & 28.5 & 49.3 \\
\hline Morogoro & 61.6 & 36.1 & 47 & 53.8 \\
\hline Mtwara & 7.4 & * & 16.5 & 20.7 \\
\hline Mwanza & 20.3 & 38.6 & 25.8 & 44 \\
\hline Pwani & 12.5 & * & 16.2 & 20.7 \\
\hline Rukwa & 6.7 & * & 14.1 & 40 \\
\hline Ruvuma & 17.7 & * & 30 & 42 \\
\hline Shinyanga & 13 & 37.7 & 22.8 & 23.3 \\
\hline Singida & 24.9 & * & 28.4 & 30.4 \\
\hline Tabora & 23.8 & 30.4 & 25.8 & 44.9 \\
\hline Tanga & 7.2 & * & 13.5 & 20.9 \\
\hline \multicolumn{5}{|l|}{ Zanzibar } \\
\hline Kaskazini Unguja & 4.4 & 10 & 6.5 & 8.5 \\
\hline Kusini Unguja & 8.2 & 13.3 & 10 & 12.1 \\
\hline Mjini Magharibi & 6.8 & 28.8 & 15.1 & 10.5 \\
\hline Kaskazini Pemba & 2.8 & 0 & 1.5 & 7.3 \\
\hline Kusini Pemba & 5.2 & 5.9 & 5.4 & 10.5 \\
\hline Mainland & 20.7 & 30 & 24.1 & 38.4 \\
\hline Zanzibar & 5.4 & 13.4 & 8.4 & 9.8 \\
\hline Urban & 18.7 & 29.5 & 22.8 & 37.6 \\
\hline Rural & 20.7 & 29.4 & 23.8 & 37.4 \\
\hline Zanzibar & 4.6 & 5.3 & 4.9 & 9.2 \\
\hline National & 20.1 & 29.4 & 23.5 & 37.4 \\
\hline
\end{tabular}

a Physical violence includes violence by a current or former spouse, or physical violence from someone other than spouse since the age of 15 . 


\begin{tabular}{|c|c|c|c|c|c|c|c|c|c|c|c|c|c|c|c|c|}
\hline \multirow[b]{2}{*}{ Region } & \multicolumn{4}{|c|}{ Physical violence ${ }^{a}$ only } & \multicolumn{4}{|c|}{ Sexual violence ${ }^{b}$ only } & \multicolumn{4}{|c|}{ Sexual or physical* violence } & \multicolumn{4}{|c|}{ Sexual and physical* violence } \\
\hline & $\begin{array}{l}15-17 \\
\text { years }\end{array}$ & $\begin{array}{l}18-19 \\
\text { years }\end{array}$ & $\begin{array}{l}15-19 \\
\text { years }\end{array}$ & $\begin{array}{l}20-24 \\
\text { years }\end{array}$ & $\begin{array}{l}15-17 \\
\text { years }\end{array}$ & $\begin{array}{l}18-19 \\
\text { years }\end{array}$ & $\begin{array}{l}15-19 \\
\text { years }\end{array}$ & $\begin{array}{l}20-24 \\
\text { years }\end{array}$ & $\begin{array}{l}15-17 \\
\text { years }\end{array}$ & $\begin{array}{l}18-19 \\
\text { years }\end{array}$ & $\begin{array}{l}15-19 \\
\text { years }\end{array}$ & $\begin{array}{l}20-24 \\
\text { years }\end{array}$ & $\begin{array}{l}15-17 \\
\text { years }\end{array}$ & $\begin{array}{l}18-19 \\
\text { years }\end{array}$ & $\begin{array}{l}15-19 \\
\text { years }\end{array}$ & $\begin{array}{l}20-24 \\
\text { years }\end{array}$ \\
\hline \multicolumn{17}{|l|}{ Mainland } \\
\hline Arusha & 11.6 & 2.9 & 8.7 & 13.6 & 0 & 17.1 & 5.7 & 5.6 & 15.1 & 24.4 & 18.3 & 23.9 & 3.6 & 4.4 & 3.8 & 4.7 \\
\hline Dar es Salaam & 6 & 2.7 & 5 & 20.9 & 7.7 & 2.7 & 6.1 & 9.5 & 21.4 & 12.6 & 18.6 & 45.2 & 7.6 & 7.2 & 7.5 & 14.7 \\
\hline Dodoma & 39.3 & * & 41.5 & 51.3 & 4.4 & * & 3 & 1.9 & 48 & * & 51.7 & 61.8 & 4.3 & * & 7.3 & 8.6 \\
\hline Iringa & 19.7 & 13.4 & 16.8 & 21.5 & 5.1 & 25.2 & 14.4 & 1.3 & 28.7 & 54.3 & 40.6 & 27.4 & 3.9 & 15.7 & 9.4 & 4.6 \\
\hline Kagera & 17.8 & 19 & 18.2 & 30.4 & 1.5 & 5 & 2.8 & 8.2 & 35.4 & 45.4 & 39.3 & 63.3 & 16.2 & 21.5 & 18.2 & 24.7 \\
\hline Kigoma & 24.1 & 7.8 & 19.4 & 23.3 & 27.9 & 20.7 & 25.8 & 13 & 52.9 & 28.5 & 45.8 & 52.5 & 0.9 & 0 & 0.7 & 16.2 \\
\hline Kilimanjaro & 4.4 & * & 5.9 & 32 & 1.7 & * & 2.3 & 4.2 & 6.1 & * & 8.2 & 36.2 & 0 & * & 0 & 0 \\
\hline Lindi & * & * & 14.8 & 15.7 & * & * & 7.5 & 14.8 & * & * & 22.3 & 39.6 & * & * & 0 & 9.1 \\
\hline Manyara & 3 & 0 & 2.1 & 20.3 & 2.2 & 20.8 & 7.9 & 6.4 & 5.2 & 20.8 & 10 & 26.8 & 0 & 0 & 0 & 0 \\
\hline Mara & 22.3 & 32.9 & 26 & 41.9 & 9.1 & 0 & 5.9 & 1 & 50.3 & 39.8 & 46.6 & 74.5 & 18.9 & 6.9 & 14.7 & 31.6 \\
\hline Mbeya & 14.1 & * & 19.1 & 23.5 & 7.8 & * & 11.2 & 5.6 & 30.2 & * & 39.7 & 54.9 & 8.4 & * & 9.4 & 25.7 \\
\hline Morogoro & 26.6 & 24.5 & 25.4 & 36.7 & 0 & 3.1 & 1.8 & 2.1 & 61.6 & 39.2 & 48.8 & 55.9 & 34.9 & 11.6 & 21.6 & 17.1 \\
\hline Mtwara & 0 & * & 8.4 & 14.2 & 9.6 & * & 5.8 & 2.2 & 17 & * & 22.3 & 23 & 7.4 & * & 8.2 & 6.5 \\
\hline Mwanza & 19.3 & 27.4 & 21.7 & 34 & 7.4 & 11 & 8.5 & 13.9 & 27.7 & 49.6 & 34.3 & 57.9 & 1 & 11.2 & 4.1 & 10 \\
\hline Pwani & 8.7 & * & 14 & 15.9 & 9.2 & * & 12.3 & 1.9 & 21.7 & * & 28.6 & 22.6 & 3.8 & * & 2.3 & 4.8 \\
\hline Rukwa & 6.7 & * & 8.2 & 23.6 & 0 & * & 5.1 & 7.8 & 6.7 & * & 19.2 & 47.8 & 0 & * & 5.9 & 16.4 \\
\hline Ruvuma & 17.7 & * & 16.5 & 20.9 & 5.4 & * & 7.7 & 10.2 & 23.2 & * & 37.7 & 52.2 & 0 & * & 13.5 & 21.1 \\
\hline Shinyanga & 13 & 32.9 & 20.9 & 14.8 & 4.2 & 0 & 2.5 & 3.2 & 17.2 & 37.7 & 25.3 & 26.4 & 0 & 4.8 & 1.9 & 8.4 \\
\hline Singida & 24.9 & * & 27.3 & 25.4 & 0 & * & 4.7 & 17.5 & 24.9 & * & 33.2 & 47.9 & 0 & * & 1.2 & 5 \\
\hline Tabora & 20.4 & 29.2 & 23.1 & 32.9 & 3.8 & 7.4 & 4.9 & 0 & 27.5 & 37.8 & 30.7 & 44.9 & 3.4 & 1.2 & 2.7 & 12.1 \\
\hline Tanga & 7.2 & * & 8.7 & 20.9 & 0 & * & 3.2 & 0 & 7.2 & * & 16.7 & 20.9 & 0 & * & 4.9 & 0 \\
\hline
\end{tabular}




\begin{tabular}{|c|c|c|c|c|c|c|c|c|c|c|c|c|c|c|c|c|}
\hline \multirow[b]{2}{*}{ Region } & \multicolumn{4}{|c|}{ Physical violence a only } & \multicolumn{4}{|c|}{ Sexual violence ${ }^{b}$ only } & \multicolumn{4}{|c|}{ Sexual or physical* violence } & \multicolumn{4}{|c|}{ Sexual and physical* violence } \\
\hline & $\begin{array}{l}15-17 \\
\text { years }\end{array}$ & $\begin{array}{l}18-19 \\
\text { years }\end{array}$ & $\begin{array}{l}15-19 \\
\text { years }\end{array}$ & $\begin{array}{l}20-24 \\
\text { years }\end{array}$ & $\begin{array}{l}15-17 \\
\text { years }\end{array}$ & $\begin{array}{l}18-19 \\
\text { years }\end{array}$ & $\begin{array}{l}15-19 \\
\text { years }\end{array}$ & $\begin{array}{l}20-24 \\
\text { years }\end{array}$ & $\begin{array}{l}15-17 \\
\text { years }\end{array}$ & $\begin{array}{l}18-19 \\
\text { years }\end{array}$ & $\begin{array}{l}15-19 \\
\text { years }\end{array}$ & $\begin{array}{l}20-24 \\
\text { years }\end{array}$ & $\begin{array}{l}15-17 \\
\text { years }\end{array}$ & $\begin{array}{l}18-19 \\
\text { years }\end{array}$ & $\begin{array}{l}15-19 \\
\text { years }\end{array}$ & $\begin{array}{l}20-24 \\
\text { years }\end{array}$ \\
\hline \multicolumn{17}{|l|}{ Zanzibar } \\
\hline $\begin{array}{l}\text { Kaskazini } \\
\text { Unguja }\end{array}$ & 4.4 & 5.9 & 5 & 8.5 & 1 & 11.2 & 4.8 & 11.2 & 5.4 & 21.2 & 11.3 & 19.7 & 0 & 4.1 & 1.5 & 0 \\
\hline Kusini Unguja & 8.2 & 13.3 & 10 & 12.1 & 0 & 12.4 & 4.5 & 11 & 8.2 & 25.6 & 14.5 & 23.1 & 0 & 0 & 0 & 0 \\
\hline $\begin{array}{c}\text { Mjini } \\
\text { Magharibi }\end{array}$ & 2 & 28.8 & 12.1 & 8.8 & 0 & 0 & 0 & 8.3 & 6.8 & 28.8 & 15.1 & 18.8 & 4.8 & 0 & 3 & 1.7 \\
\hline $\begin{array}{l}\text { Kaskazini } \\
\text { Pemba }\end{array}$ & 2.8 & 0 & 1.5 & 1.9 & 3 & 0 & 1.7 & 3.3 & 5.8 & 0 & 3.2 & 10.7 & 0 & 0 & 0 & 5.5 \\
\hline Kusini Pemba & 5.2 & 5.9 & 5.4 & 6.1 & 0 & 0 & 0 & 3.6 & 5.2 & 5.9 & 5.4 & 14.2 & 0 & 0 & 0 & 4.5 \\
\hline Mainland & 15.2 & 20.4 & 17.1 & 25.9 & 5.7 & 8.3 & 6.6 & 6.3 & 26.4 & 38.3 & 30.7 & 44.8 & 5.5 & 9.6 & 7 & 12.6 \\
\hline Zanzibar & 3.7 & 12.8 & 7.1 & 7.5 & 0.7 & 2.6 & 1.4 & 7.5 & 6.1 & 16 & 9.8 & 17.3 & 1.6 & 0.7 & 1.3 & 2.3 \\
\hline Urban & 13.5 & 22.4 & 16.9 & 25.9 & 5.3 & 4.2 & 4.8 & 7.8 & 24 & 33.6 & 27.6 & 45.4 & 5.2 & 7 & 5.9 & 11.7 \\
\hline Rural & 15.3 & 19.1 & 16.7 & 24.9 & 5.6 & 9.8 & 7.1 & 5.7 & 26.3 & 39.2 & 30.9 & 43.1 & 5.4 & 10.3 & 7.1 & 12.4 \\
\hline National & 14.8 & 20.1 & 16.7 & 25.2 & 5.5 & 8.1 & 6.4 & 6.4 & 25.7 & 37.5 & 29.9 & 43.8 & 5.3 & 9.3 & 6.8 & 12.2 \\
\hline
\end{tabular}

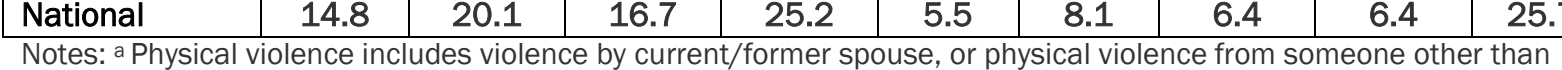

spouse since the age of 15. 'b Sexual violence includes sexual violence by husband/partner, ever forced to perform

unwanted sexual acts by anyone, ever forced to have sex by anyone other than current partner in past 12 months, and

first sex was forced by anyone.

Annex Table 30B-1: VACS 2009, Among Females Who Have Experienced Physical Violence, Percent Who Report Specific Persons ${ }^{a}$ Committing Violence, by Age

\begin{tabular}{|c|c|c|c|c|c|c|c|c|c|c|c|c|}
\hline \multirow[b]{2}{*}{ Region } & \multicolumn{4}{|c|}{ Partner (Current/former partner) } & \multicolumn{4}{|c|}{ Parent or adult relative } & \multicolumn{4}{|c|}{ Otherb $^{b}$} \\
\hline & $\begin{array}{l}15-17 \\
\text { years }\end{array}$ & $\begin{array}{l}18-19 \\
\text { years }\end{array}$ & $\begin{array}{l}15-19 \\
\text { years }\end{array}$ & $\begin{array}{l}20-24 \\
\text { years }\end{array}$ & $\begin{array}{l}15-17 \\
\text { years }\end{array}$ & $\begin{array}{l}18-19 \\
\text { years }\end{array}$ & $\begin{array}{l}15-19 \\
\text { years }\end{array}$ & $\begin{array}{l}20-24 \\
\text { years }\end{array}$ & $\begin{array}{l}15-17 \\
\text { years }\end{array}$ & $\begin{array}{l}18-19 \\
\text { years }\end{array}$ & $\begin{array}{l}15-19 \\
\text { years }\end{array}$ & 20-24 years \\
\hline Mainland & 6.2 & 15.1 & 9.8 & 29.8 & 83.2 & 76.8 & 80.7 & 75.2 & 79.9 & 66.3 & 74.4 & 69.7 \\
\hline Zanzibar & 0.7 & 8.4 & 3.7 & 7.4 & 82.8 & 71 & 78.2 & 64.8 & 79.9 & 67.2 & 75 & 72.7 \\
\hline National & 6.1 & 15 & 9.7 & 29.3 & 83.2 & 76.7 & 80.6 & 75 & 79.9 & 66.3 & 74.5 & 69.8 \\
\hline
\end{tabular}

a Percents do not sum to $100 \%$ because person is reporting on up to 8 incidents of sexual violence each of which could have a different perpetrator and not all respondents provided full information. ${ }^{b}$ Includes teacher, religious leader, police, employer, or stranger. 
Annex Table 30B-2: VACS 2009, Among Males Who Have Experienced Physical Violence, Percent Who Report Specific Persons ${ }^{a}$ Committing

Violence, by Age

\begin{tabular}{|c|c|c|c|c|c|c|c|c|c|c|c|c|}
\hline \multirow[b]{2}{*}{ Region } & \multicolumn{4}{|c|}{ Partner (Current/former partner) } & \multicolumn{4}{|c|}{ Parent or adult relative } & \multicolumn{4}{|c|}{ Otherb } \\
\hline & $\begin{array}{l}15-17 \\
\text { years }\end{array}$ & $\begin{array}{l}18-19 \\
\text { years }\end{array}$ & $\begin{array}{l}15-19 \\
\text { years }\end{array}$ & $\begin{array}{l}20-24 \\
\text { years }\end{array}$ & $\begin{array}{l}15-17 \\
\text { years }\end{array}$ & $\begin{array}{l}18-19 \\
\text { years }\end{array}$ & $\begin{array}{l}15-19 \\
\text { years }\end{array}$ & $\begin{array}{l}20-24 \\
\text { years }\end{array}$ & $\begin{array}{l}15-17 \\
\text { years }\end{array}$ & $\begin{array}{l}18-19 \\
\text { years }\end{array}$ & $\begin{array}{l}15-19 \\
\text { years }\end{array}$ & $\begin{array}{l}20-24 \\
\text { years }\end{array}$ \\
\hline Mainland & 1.2 & 9 & 4.3 & 18.3 & 80 & 76.1 & 78.5 & 74.8 & 78.6 & 80.5 & 79.4 & 61.8 \\
\hline ZNZ & 4.8 & 9.3 & 6.6 & 15.4 & 92.9 & 76.4 & 86.4 & 85.1 & 58 & 71.2 & 63.2 & 65.8 \\
\hline National & 1.3 & 9 & 4.4 & 18.2 & 80.4 & 76.1 & 78.7 & 75.2 & 78.1 & 80.3 & 79 & 61.9 \\
\hline
\end{tabular}

a Percents do not sum to $100 \%$ because person is reporting on up to 8 incidents of sexual violence each of which could have a different perpetrator and not all

respondents provided full information. ${ }^{\mathrm{b}}$ Includes teacher, religious leader, police, employer, or stranger.

Annex Table 31B: VACS 2009, Percent of Females Whose Pregnancy Ever Resulted from Forced Sex, by Age

\begin{tabular}{|c|c|c|c|c|c|c|c|c|c|c|c|c|}
\hline \multirow[b]{2}{*}{ Region } & \multicolumn{4}{|c|}{ No } & \multicolumn{4}{|c|}{ Yes } & \multicolumn{4}{|c|}{ Don't Know } \\
\hline & $\begin{array}{l}15-17 \\
\text { years }\end{array}$ & $\begin{array}{l}18-19 \\
\text { years }\end{array}$ & $\begin{array}{l}15-19 \\
\text { years }\end{array}$ & $\begin{array}{c}20-24 \\
\text { years }\end{array}$ & $\begin{array}{l}15-17 \\
\text { years }\end{array}$ & $\begin{array}{l}18-19 \\
\text { years }\end{array}$ & $\begin{array}{l}15-19 \\
\text { years }\end{array}$ & $\begin{array}{c}20-24 \\
\text { years }\end{array}$ & $\begin{array}{l}15-17 \\
\text { years }\end{array}$ & $\begin{array}{l}18-19 \\
\text { years }\end{array}$ & $\begin{array}{l}15-19 \\
\text { years }\end{array}$ & $\begin{array}{l}20-24 \\
\text { years }\end{array}$ \\
\hline Mainland & 3.1 & 1.9 & 2.6 & 3.4 & 4.1 & 7.5 & 5.5 & 8.5 & 92.8 & 90.6 & 91.9 & 88 \\
\hline Zanzibar & 0.5 & 1 & 0.7 & 0.5 & 0.1 & 2.6 & 1.1 & 1.1 & 99.4 & 96.4 & 98.2 & 98.5 \\
\hline National & 3 & 1.8 & 2.6 & 3.4 & 4 & 7.4 & 5.4 & 8.3 & 93 & 90.8 & 92.1 & 88.3 \\
\hline
\end{tabular}




\begin{tabular}{|c|c|c|c|c|c|c|c|c|c|c|c|c|}
\hline \multirow{3}{*}{$\begin{array}{c}\text { Annex Table } 3 \\
\text { Region }\end{array}$} & \multirow{2}{*}{\multicolumn{4}{|c|}{$\begin{array}{l}\text { L: HIV Prevention Knowledge amo } \\
\text { Know that using a condom can } \\
\text { reduce risk of HIVa }\end{array}$}} & \multirow{2}{*}{\multicolumn{4}{|c|}{$\begin{array}{c}\text { Females Ages } 15-24 \text {, Percent (DF } \\
\text { Know that having one partner } \\
\text { and no others can reduce risk of } \\
\text { HIV }\end{array}$}} & \multirow{2}{*}{\multicolumn{4}{|c|}{$\begin{array}{l}\text { Knowledge of both prevention } \\
\text { methods }\end{array}$}} \\
\hline & & & & & & & & & & & & \\
\hline & $\begin{array}{l}15-17 \\
\text { years }\end{array}$ & $\begin{array}{c}18- \\
19 \\
\text { years }\end{array}$ & $\begin{array}{l}15-19 \\
\text { years }\end{array}$ & $\begin{array}{c}20- \\
24 \\
\text { years }\end{array}$ & $\begin{array}{l}15-17 \\
\text { years }\end{array}$ & $\begin{array}{l}18-19 \\
\text { years }\end{array}$ & $\begin{array}{l}15-19 \\
\text { years }\end{array}$ & $\begin{array}{c}20- \\
24 \\
\text { years }\end{array}$ & $\begin{array}{c}15- \\
17 \\
\text { years }\end{array}$ & $\begin{array}{l}18-19 \\
\text { years }\end{array}$ & $\begin{array}{l}15-19 \\
\text { years }\end{array}$ & $\begin{array}{c}20- \\
24 \\
\text { years }\end{array}$ \\
\hline \multicolumn{13}{|l|}{ Mainland } \\
\hline Arusha & 50.6 & 70.1 & 57.8 & 63.8 & 86 & 79.6 & 83.6 & 78.5 & 43.7 & 60.7 & 49.9 & 57.1 \\
\hline Dar es Salaam & 77.8 & 80.9 & 78.8 & 80 & 87.7 & 90.3 & 88.6 & 93.2 & 71.1 & 73.9 & 72 & 75.5 \\
\hline Dodoma & 82.1 & * & 86.5 & 95 & 94 & * & 95.5 & 100 & 77.8 & * & 83.3 & 95 \\
\hline Iringa & 60.6 & 80.6 & 68.9 & 77.5 & 79.9 & 93.1 & 85.4 & 96 & 50.5 & 77.2 & 61.6 & 77.5 \\
\hline Kagera & 80 & 85.2 & 81.9 & 91.6 & 88 & 84.5 & 86.7 & 92.5 & 74.3 & 78.6 & 75.9 & 85.3 \\
\hline Kigoma & 72.3 & * & 73.7 & 78.1 & 81.8 & * & 83 & 96.6 & 62.8 & 64.8 & 63.3 & 77.2 \\
\hline Kilimanjaro & 54.4 & * & 61.7 & 85.3 & 92.2 & * & 94.5 & 97.7 & 54.4 & * & 60.8 & 85.3 \\
\hline Lindi & * & * & 84.2 & 79 & * & * & 82 & 95.7 & * & * & 72.4 & 77.5 \\
\hline Manyara & 45 & 78 & 58 & 63.1 & 73.6 & 91.6 & 80.7 & 88.2 & 36.7 & 75.8 & 51.4 & 59.6 \\
\hline Mara & 66.4 & 63.8 & 65.5 & 69.9 & 86 & 74.5 & 82 & 78 & 59.9 & 49.9 & 56.4 & 59.5 \\
\hline Mbeya & 71.4 & * & 74.9 & 77.2 & 83.2 & * & 81 & 93 & 63.3 & * & 65 & 75 \\
\hline Morogoro & 67.6 & 69 & 68.3 & 82.9 & 85.4 & 88 & 86.7 & 88.3 & 65.5 & 65 & 65.3 & 79.1 \\
\hline Mtwara & 78.6 & * & 78.1 & 88.5 & 86.4 & * & 91.3 & 98.1 & 72.5 & * & 74.1 & 85.1 \\
\hline Mwanza & 39.8 & 64.1 & 48.5 & 55.8 & 53.3 & 75.7 & 61.3 & 80.9 & 26.9 & 51 & 35.5 & 50.1 \\
\hline Pwani & 90.9 & * & 94.7 & 83.9 & 100 & * & 98.7 & 95.8 & 90.9 & * & 93.4 & 81.1 \\
\hline Rukwa & 69.9 & * & 70.1 & 73.6 & 82 & * & 85.4 & 84 & 61.3 & * & 64.5 & 68.6 \\
\hline Ruvuma & 79.6 & * & 77.8 & 88.8 & 81.7 & * & 83.3 & 88.9 & 66.3 & * & 67.7 & 83.5 \\
\hline Shinyanga & 71.2 & 80.7 & 75.3 & 80.7 & 68.6 & 78.1 & 72.7 & 77.1 & 60.2 & 74.3 & 66.3 & 69.8 \\
\hline Singida & 82.1 & * & 79.4 & 66 & 90.6 & * & 90 & 83 & 74.1 & * & 72.4 & 59.4 \\
\hline Tabora & 75.6 & 76.7 & 76 & 84.2 & 73 & 71.8 & 72.5 & 87.3 & 65.8 & 62.3 & 64.4 & 74.9 \\
\hline Tanga & 73.2 & * & 69.4 & 80.5 & 90.5 & * & 89.2 & 98.4 & 69.2 & * & 66.6 & 78.9 \\
\hline \multicolumn{13}{|l|}{ Zanzibar } \\
\hline $\begin{array}{c}\text { Kaskazini } \\
\text { Unguja }\end{array}$ & 46.3 & 49.4 & 47.5 & 57.6 & 83.8 & 85.8 & 84.6 & 85.9 & 43.7 & 43.6 & 43.7 & 54.7 \\
\hline Kusini Unguja & 67.9 & 73.4 & 70.1 & 71.5 & 72.9 & 80.8 & 76.1 & 87.6 & 56.5 & 61.4 & 58.4 & 63 \\
\hline $\begin{array}{c}\text { Mjini } \\
\text { Magharibi }\end{array}$ & 59.5 & 70.4 & 63.8 & 67 & 88.4 & 87.6 & 88.1 & 96.6 & 56.8 & 62.4 & 59 & 66.3 \\
\hline $\begin{array}{c}\text { Kaskazini } \\
\text { Pemba }\end{array}$ & 49.6 & 73.9 & 58 & 51.9 & 81.7 & 92.9 & 85.6 & 89.9 & 46 & 71.5 & 54.8 & 50.8 \\
\hline Kusini Pemba & 55.9 & 66.5 & 59.5 & 66.8 & 82.4 & 92.6 & 85.9 & 90 & 52.4 & 63.9 & 56.3 & 61.6 \\
\hline Mainland & 68.7 & 76.9 & 71.7 & 78.3 & 81.1 & 84.6 & 82.3 & 89.3 & 61.1 & 69.6 & 64.2 & 73.5 \\
\hline Zanzibar & 55.3 & 67.1 & 59.7 & 63.3 & 83.8 & 88.6 & 85.6 & 91.9 & 51.5 & 61.2 & 55.1 & 60.8 \\
\hline Urban & 69.5 & 80.9 & 73.5 & 80.2 & 88 & 92.4 & 89.6 & 94.8 & 63.9 & 75.5 & 68 & 78 \\
\hline Rural & 67.7 & 74.7 & 70.2 & 76.6 & 78.2 & 81.6 & 79.4 & 86.7 & 59.4 & 66.7 & 62.1 & 70.7 \\
\hline National & 68.3 & 76.5 & 71.2 & 77.8 & 81.2 & 84.8 & 82.5 & 89.4 & 60.8 & 69.3 & 63.8 & 73.1 \\
\hline
\end{tabular}

a Using condoms every time they have sexual intercourse; b partner who has no other partners. 


\begin{tabular}{|c|c|c|c|c|c|c|c|c|c|c|c|c|}
\hline \multicolumn{13}{|c|}{ Annex Table 33 A-2: HIV Prevention Knowledge among Males Ages 15-24, Percent (DHS 2010) } \\
\hline \multirow{2}{*}{ Region } & \multicolumn{4}{|c|}{$\begin{array}{l}\text { Know that using a condom can } \\
\text { reduce risk of HIVa }\end{array}$} & \multicolumn{4}{|c|}{$\begin{array}{c}\text { Know that having one partnerb } \\
\text { and no others can reduce risk of } \\
\text { HIV }\end{array}$} & \multicolumn{4}{|c|}{$\begin{array}{l}\text { Knowledge of both prevention } \\
\text { methods }\end{array}$} \\
\hline & $\begin{array}{l}15-17 \\
\text { years }\end{array}$ & $\begin{array}{c}18- \\
19 \\
\text { years } \\
\end{array}$ & $\begin{array}{l}15-19 \\
\text { years }\end{array}$ & $\begin{array}{c}20- \\
24 \\
\text { years }\end{array}$ & $\begin{array}{l}15-17 \\
\text { years }\end{array}$ & $\begin{array}{l}18-19 \\
\text { years }\end{array}$ & $\begin{array}{l}15-19 \\
\text { years }\end{array}$ & $\begin{array}{c}20- \\
24 \\
\text { years }\end{array}$ & $\begin{array}{c}15- \\
17 \\
\text { years }\end{array}$ & $\begin{array}{l}18-19 \\
\text { years }\end{array}$ & $\begin{array}{l}15-19 \\
\text { years }\end{array}$ & $\begin{array}{c}20- \\
24 \\
\text { years }\end{array}$ \\
\hline \multicolumn{13}{|l|}{ Mainland } \\
\hline Arusha & * & * & * & * & * & * & * & * & * & * & * & * \\
\hline Dar es Salaam & * & * & 69.3 & * & * & * & 82.1 & * & * & * & 59 & * \\
\hline Dodoma & * & * & * & * & * & * & * & * & * & * & * & * \\
\hline Iringa & * & * & 75.6 & * & * & * & 82.7 & * & * & * & 62.8 & * \\
\hline Kagera & * & * & 60.9 & * & * & * & 85.4 & * & * & * & 56.5 & * \\
\hline Kigoma & * & * & * & * & * & * & * & * & * & * & * & * \\
\hline Kilimanjaro & * & * & 60.7 & * & * & * & 85 & * & * & * & 53.2 & * \\
\hline Lindi & * & * & * & * & * & * & * & * & * & * & * & * \\
\hline Manyara & * & * & * & * & * & * & * & * & * & * & * & * \\
\hline Mara & * & * & 75.7 & * & * & * & 64.8 & * & * & * & 49.4 & * \\
\hline Mbeya & * & * & 65.5 & * & * & * & 80.1 & * & * & * & 61.5 & * \\
\hline Morogoro & * & * & 64.7 & * & * & * & 83.1 & * & * & * & 57.2 & * \\
\hline Mtwara & * & * & * & * & * & * & * & * & * & * & * & * \\
\hline Mwanza & 78 & * & 71.1 & 84.6 & 81 & * & 84.1 & 100 & 59 & * & 55.2 & 84.6 \\
\hline Pwani & * & * & * & * & * & * & * & * & * & * & * & * \\
\hline Rukwa & * & * & * & * & * & * & * & * & * & * & * & * \\
\hline Ruvuma & * & * & * & * & * & * & * & * & * & * & * & * \\
\hline Shinyanga & * & * & 72.5 & * & * & * & 90.4 & * & * & * & 66.1 & * \\
\hline Singida & * & * & 80.4 & * & * & * & 89.4 & * & * & * & 69.8 & * \\
\hline Tabora & * & * & 82.5 & * & * & * & 87.2 & * & * & * & 69.7 & * \\
\hline Tanga & * & * & * & * & * & * & * & * & * & * & * & * \\
\hline \multicolumn{13}{|l|}{ Zanzibar } \\
\hline $\begin{array}{c}\text { Kaskazini } \\
\text { Unguja }\end{array}$ & 47.7 & * & 43.2 & * & 70.4 & * & 67 & * & 40.1 & * & 35.1 & * \\
\hline Kusini Unguja & * & * & 63.6 & 74.3 & * & * & 65 & 76.5 & * & * & 41.5 & 59.8 \\
\hline $\begin{array}{c}\text { Mjini } \\
\text { Magharibi }\end{array}$ & * & * & 51.7 & * & * & * & 82.4 & * & * & * & 42.3 & * \\
\hline $\begin{array}{c}\text { Kaskazini } \\
\text { Pemba }\end{array}$ & * & * & 34.7 & * & * & * & 60.9 & * & * & * & 25.9 & * \\
\hline Kusini Pemba & * & * & 57.5 & 37.9 & * & * & 56.9 & 84.7 & * & * & 32.1 & 30.1 \\
\hline Mainland & 69.5 & 70.8 & 70 & 78.1 & 79.8 & 89.9 & 83.6 & 93 & 57.8 & 65.1 & 60.6 & 74.4 \\
\hline Zanzibar & 54.3 & 41.8 & 49.1 & 52.7 & 66.3 & 74.7 & 69.8 & 78.7 & 40.5 & 30.3 & 36.3 & 47.3 \\
\hline Urban & 76.4 & 76.9 & 76.6 & 75 & 83.7 & 95.7 & 89 & 95.3 & 68.2 & 73.1 & 70.3 & 72.9 \\
\hline Rural & 66.9 & 66.8 & 66.9 & 78.3 & 78.1 & 86.7 & 81.2 & 91.4 & 54.1 & 60 & 56.2 & 73.8 \\
\hline National & 69.1 & 69.7 & 69.3 & 77.3 & 79.4 & 89.4 & 83.1 & 92.6 & 57.3 & 63.8 & 59.7 & 73.5 \\
\hline
\end{tabular}

a Using condoms every time they have sexual intercourse; b partner who has no other partners. 


\begin{tabular}{|c|c|c|c|c|c|c|c|c|c|c|c|c|}
\hline \multicolumn{13}{|c|}{ Table 33B-1: HIV Prevention Knowledge among Females Ages 15-24, Percent (THMIS 2011-2012) } \\
\hline \multirow{2}{*}{ Region } & \multicolumn{4}{|c|}{$\begin{array}{l}\text { Know that using a condom can } \\
\text { reduce risk of HIVa }\end{array}$} & \multicolumn{4}{|c|}{$\begin{array}{c}\text { Know that having one partnerb } \\
\text { and no others can reduce risk of } \\
\text { HIV }\end{array}$} & \multicolumn{4}{|c|}{$\begin{array}{l}\text { Knowledge of both prevention } \\
\text { methods }\end{array}$} \\
\hline & $\begin{array}{l}15-17 \\
\text { years }\end{array}$ & $\begin{array}{c}18- \\
19 \\
\text { years }\end{array}$ & $\begin{array}{l}15-19 \\
\text { years }\end{array}$ & $\begin{array}{c}20- \\
24 \\
\text { years }\end{array}$ & $\begin{array}{l}15-17 \\
\text { years }\end{array}$ & $\begin{array}{c}18-19 \\
\text { years }\end{array}$ & $\begin{array}{l}15-19 \\
\text { years }\end{array}$ & $\begin{array}{c}20- \\
24 \\
\text { years }\end{array}$ & $\begin{array}{c}15- \\
17 \\
\text { years }\end{array}$ & $\begin{array}{l}18-19 \\
\text { years }\end{array}$ & $\begin{array}{l}15-19 \\
\text { years }\end{array}$ & $\begin{array}{c}20- \\
24 \\
\text { years }\end{array}$ \\
\hline \multicolumn{13}{|l|}{ Mainland } \\
\hline Arusha & 68.2 & * & 67.1 & 52.2 & 87.9 & * & 86.3 & 88.1 & 63.4 & 56.8 & 61 & 51.1 \\
\hline Dar es Salaam & 56.5 & 72.1 & 63.3 & 85.8 & 92.5 & 93.7 & 93 & 97.1 & 56.5 & 70 & 62.4 & 84.3 \\
\hline Dodoma & * & * & 72.9 & 61 & * & * & 84.9 & 80.9 & * & * & 63.1 & 58 \\
\hline Geita & 50.7 & 65.5 & 55.4 & 78.7 & 76 & 84.3 & 78.6 & 90.2 & 46.5 & 59 & 50.4 & 71.5 \\
\hline Iringa & 58.1 & 67.1 & 63.3 & 90.2 & 74.3 & 98 & 88 & 90.2 & 55.1 & 65.1 & 60.9 & 80.4 \\
\hline Kagera & 70.2 & 64.4 & 68.1 & 79.8 & 89.8 & 84.3 & 87.8 & 91 & 63.7 & 64.4 & 63.9 & 72.7 \\
\hline Katavi & 34.4 & 65.1 & 47.4 & 60.7 & 63.7 & 69.4 & 66.1 & 84.4 & 25.6 & 52.9 & 36.5 & 58.3 \\
\hline Kigoma & 39.3 & 66.4 & 50.7 & 71.2 & 78.2 & 77.7 & 78 & 95.6 & 37.2 & 55.4 & 44.9 & 70.1 \\
\hline Kilimanjaro & 31.4 & 56.8 & 41.6 & 66.6 & 85.3 & 93.8 & 88.7 & 93.3 & 30.9 & 50.5 & 38.7 & 63.2 \\
\hline Lindi & 81.8 & * & 85.5 & 86.8 & 73.9 & * & 78.7 & 89.4 & 67.8 & * & 72.5 & 81.8 \\
\hline Manyara & 50 & 67 & 55.3 & 66.6 & 73.8 & 83.5 & 76.8 & 89.8 & 41.8 & 67 & 49.4 & 65.1 \\
\hline Mara & 62.3 & 73.9 & 67.2 & 84.3 & 67.1 & 73.1 & 69.6 & 74.3 & 47.4 & 50.7 & 48.8 & 67.7 \\
\hline Mbeya & 40.1 & 55.4 & 46.3 & 55.4 & 59.9 & 74.4 & 65.8 & 81.5 & 31.3 & 45.7 & 37.1 & 47.3 \\
\hline Morogoro & 77.2 & 75.5 & 76.3 & 77.8 & 90.1 & 80.9 & 85 & 91.3 & 74 & 66.3 & 69.8 & 73.7 \\
\hline Mtwara & 64.3 & * & 71.3 & 88.2 & 72.8 & * & 78.2 & 92.5 & 55.4 & * & 64.4 & 82.5 \\
\hline Mwanza & 65 & 68.2 & 66.2 & 75.7 & 61.1 & 84 & 69.7 & 79.5 & 46.5 & 64.8 & 53.2 & 68.2 \\
\hline Njombe & 56.8 & * & 60.1 & 78.7 & 84.4 & * & 86.7 & 95.9 & 56.3 & * & 57.2 & 76.7 \\
\hline Pwani & 75.1 & * & 81.2 & 78.9 & 83.2 & * & 88 & 87.4 & 75.1 & * & 81.2 & 73.5 \\
\hline Rukwa & 57.1 & * & 59.7 & 77.3 & 83.1 & * & 84 & 79.4 & 41.5 & * & 48.2 & 65.2 \\
\hline Ruvuma & 76 & 94.7 & 83.5 & 71.6 & 68.5 & 95.6 & 79.4 & 70.8 & 64.1 & 86.1 & 73.2 & 61.8 \\
\hline Shinyanga & 63 & 85 & 71.8 & 87.5 & 73.8 & 89.1 & 79.9 & 88.5 & 52.2 & 81.1 & 63.8 & 80.4 \\
\hline Simiyu & 46.8 & 44.4 & 45.8 & 62.9 & 44.5 & 46.6 & 45.4 & 57.9 & 28.1 & 32.8 & 30 & 37.1 \\
\hline Singida & 57 & 71.5 & 63.1 & 71.5 & 77.7 & 90.1 & 82.9 & 82.9 & 49.3 & 64.2 & 55.3 & 63.7 \\
\hline Tabora & 72 & 90.4 & 78.8 & 82.1 & 88.5 & 95.2 & 91 & 94.1 & 67.6 & 85.6 & 74.2 & 78.8 \\
\hline Tanga & 37.5 & 32.7 & 35.4 & 49.1 & 65.7 & 84.3 & 73.7 & 71.3 & 28.2 & 29.4 & 28.7 & 41.6 \\
\hline \multicolumn{13}{|l|}{ Zanzibar } \\
\hline $\begin{array}{l}\text { Kaskazini } \\
\text { Unguja }\end{array}$ & 41.6 & 34 & 39 & 49.8 & 68.8 & 81.2 & 73.1 & 85.7 & 29.9 & 33.1 & 31 & 46.4 \\
\hline Kusini Unguja & 59.2 & * & 53.6 & 60.3 & 89.2 & * & 85 & 86.7 & 51.1 & * & 48.7 & 51.8 \\
\hline $\begin{array}{c}\text { Mjini } \\
\text { Magharibi }\end{array}$ & 23.9 & 53.3 & 36.7 & 55.8 & 82.4 & 88.6 & 85.1 & 95 & 22.6 & 53.3 & 36 & 55 \\
\hline $\begin{array}{l}\text { Kaskazini } \\
\text { Pemba }\end{array}$ & 51.4 & 51.9 & 51.6 & 61.6 & 76.8 & 90.4 & 81.8 & 90.4 & 47 & 51.9 & 48.8 & 61.6 \\
\hline Kusini Pemba & 54.7 & 58 & 56 & 57.3 & 85.8 & 92.4 & 88.4 & 97.6 & 54.7 & 58 & 56 & 56.5 \\
\hline Mainland & 56.5 & 68.7 & 61.4 & 73.6 & 74.2 & 82.7 & 77.6 & 84.9 & 48.2 & 61.2 & 53.4 & 66.6 \\
\hline Zanzibar & 35.6 & 51.6 & 42.1 & 56.3 & 80.9 & 88 & 83.8 & 93.4 & 32.4 & 51.5 & 40.2 & 54.8 \\
\hline Urban & 64.8 & 79.3 & 70.3 & 78.8 & 85.6 & 91.5 & 87.8 & 93.7 & 59.9 & 74.9 & 65.6 & 76.3 \\
\hline Rural & 52 & 64.1 & 57 & 70.7 & 70.1 & 80 & 74.2 & 82.1 & 42.8 & 56.1 & 48.3 & 62.4 \\
\hline National & 55.6 & 68 & 60.6 & 72.9 & 74.5 & 82.9 & 77.9 & 85.3 & 47.5 & 60.8 & 52.9 & 66.1 \\
\hline
\end{tabular}

a Using condoms every time they have sexual intercourse; ${ }^{b}$ partner who has no other partners. 


\begin{tabular}{|c|c|c|c|c|c|c|c|c|c|c|c|c|}
\hline \multicolumn{13}{|c|}{ Table 33B-2: HIV Prevention Knowledge among Males Ages 15-24, Percent (THMIS 2011-2012) } \\
\hline \multirow{2}{*}{ Region } & \multicolumn{4}{|c|}{$\begin{array}{l}\text { Know that using a condom can } \\
\text { reduce risk of HIVa }\end{array}$} & \multicolumn{4}{|c|}{$\begin{array}{c}\text { Know that having one partnerb } \\
\text { and no others can reduce risk of } \\
\text { HIV }\end{array}$} & \multicolumn{4}{|c|}{$\begin{array}{l}\text { Knowledge of both prevention } \\
\text { methods }\end{array}$} \\
\hline & $\begin{array}{l}15-17 \\
\text { years }\end{array}$ & $\begin{array}{c}18- \\
19 \\
\text { years }\end{array}$ & $\begin{array}{l}15-19 \\
\text { years }\end{array}$ & $\begin{array}{c}20- \\
24 \\
\text { years }\end{array}$ & $\begin{array}{l}15-17 \\
\text { years }\end{array}$ & $\begin{array}{l}18-19 \\
\text { years }\end{array}$ & $\begin{array}{l}15-19 \\
\text { years }\end{array}$ & $\begin{array}{c}20- \\
24 \\
\text { years }\end{array}$ & $\begin{array}{c}15- \\
17 \\
\text { years }\end{array}$ & $\begin{array}{l}18-19 \\
\text { years }\end{array}$ & $\begin{array}{l}15-19 \\
\text { years }\end{array}$ & $\begin{array}{c}20- \\
24 \\
\text { years }\end{array}$ \\
\hline \multicolumn{13}{|l|}{ Mainland } \\
\hline Arusha & 77.9 & * & 78 & 91.8 & 76.1 & * & 76.7 & 100 & 61.2 & * & 65.9 & 91.8 \\
\hline Dar es Salaam & 85.3 & 72.9 & 79.3 & 83.5 & 82.2 & 75 & 78.7 & 93.9 & 73.4 & 63 & 68.3 & 81.5 \\
\hline Dodoma & 87.3 & * & 78.6 & 63.6 & 87.5 & * & 88.8 & 81.3 & 75.2 & * & 71.3 & 61.3 \\
\hline Geita & 69.3 & 78 & 72.5 & 76 & 54.2 & 58 & 55.6 & 79.2 & 39.9 & 45.9 & 42.1 & 61.7 \\
\hline Iringa & 91.1 & 94.3 & 92.4 & 70.3 & 88.3 & 93.6 & 90.5 & 88.6 & 88 & 84.7 & 86.6 & 70.3 \\
\hline Kagera & 58.2 & * & 63.1 & 71.8 & 72.9 & * & 73.9 & 94.9 & 48.1 & * & 51.3 & 69.1 \\
\hline Katavi & 82.4 & * & 85.7 & 90.7 & 89.9 & * & 93.8 & 95.4 & 75.4 & * & 81.3 & 90.7 \\
\hline Kigoma & 62.4 & 46.2 & 55 & 80.8 & 81.6 & 95.5 & 88 & 85.8 & 55.1 & 45.7 & 50.8 & 70.6 \\
\hline Kilimanjaro & 74.8 & 84.8 & 79.5 & 84.3 & 84.6 & 96.9 & 90.3 & 96.5 & 65.2 & 84.8 & 74.2 & 80.8 \\
\hline Lindi & 91.2 & * & 90.2 & 87.9 & 95.6 & * & 94.7 & 100 & 91.2 & * & 87.6 & 87.9 \\
\hline Manyara & 79.1 & 85.7 & 82.4 & 84.1 & 85.9 & 87.9 & 86.9 & 89.3 & 71.4 & 80.1 & 75.8 & 80.3 \\
\hline Mara & 71.3 & 81 & 74.3 & 85.4 & 60.9 & 83.7 & 67.9 & 89.3 & 52.2 & 72.3 & 58.4 & 77.1 \\
\hline Mbeya & 78 & 76.6 & 77.4 & 86.9 & 87.7 & 85.1 & 86.7 & 97.1 & 73.4 & 65.8 & 70.4 & 84 \\
\hline Morogoro & 87.8 & 85.5 & 86.6 & 84.8 & 82 & 89.3 & 85.7 & 87.5 & 69.8 & 78.1 & 74 & 77.6 \\
\hline Mtwara & 84.2 & * & 78.8 & 92.3 & 88.2 & * & 90.7 & 93.8 & 75.2 & * & 71.4 & 87.5 \\
\hline Mwanza & 66.9 & 66.4 & 66.7 & 69 & 62.1 & 88.5 & 73 & 79.8 & 39.1 & 58 & 46.8 & 56.4 \\
\hline Njombe & 66.7 & * & 67.3 & 79.4 & 54.2 & * & 65.8 & 90.3 & 48.3 & * & 53.7 & 75.6 \\
\hline Pwani & 78.3 & 69.6 & 74.3 & 59.9 & 66.1 & 92.8 & 78.4 & 98 & 47.8 & 66.9 & 56.6 & 57.9 \\
\hline Rukwa & * & * & 70.3 & 90.3 & * & * & 73.4 & 97.6 & 50.7 & * & 57.5 & 90.3 \\
\hline Ruvuma & 66 & * & 73.3 & 90 & 67.3 & * & 73.8 & 78.6 & 45.1 & * & 57.4 & 76 \\
\hline Shinyanga & 61.5 & * & 64.5 & 73.4 & 64.5 & * & 73.5 & 89 & 51.1 & * & 54.9 & 70.7 \\
\hline Simiyu & 60.9 & 81.1 & 68.3 & 66.2 & 63 & 72.8 & 66.6 & 74.8 & 37.2 & 55.7 & 43.8 & 56 \\
\hline Singida & 72.3 & 70.7 & 71.6 & 84.8 & 69.3 & 81.8 & 74.5 & 78.2 & 62.7 & 60.3 & 61.7 & 67.9 \\
\hline Tabora & 65.4 & 80.1 & 71 & 80.5 & 79.2 & 67.5 & 74.7 & 88.7 & 61.4 & 62.6 & 61.9 & 74.4 \\
\hline Tanga & 55.1 & * & 62.5 & 85.5 & 77.1 & * & 81.8 & 91.9 & 50.1 & * & 59.4 & 85.5 \\
\hline \multicolumn{13}{|l|}{ Zanzibar } \\
\hline $\begin{array}{l}\text { Kaskazini } \\
\text { Unguja }\end{array}$ & 54.6 & * & 45.5 & 45.2 & 77.3 & * & 73.8 & 90.9 & 45.2 & * & 35.1 & 42.8 \\
\hline Kusini Unguja & 68.9 & * & 64.1 & 57.4 & 81.5 & * & 78.2 & 62.7 & 61.9 & * & 57 & 45 \\
\hline $\begin{array}{c}\text { Mjini } \\
\text { Magharibi }\end{array}$ & 34.6 & * & 40.7 & 36.3 & 88.3 & * & 83.9 & 82.9 & 26.2 & * & 34.4 & 35.4 \\
\hline $\begin{array}{l}\text { Kaskazini } \\
\text { Pemba }\end{array}$ & 48.6 & 42.1 & 45.7 & 54.3 & 56.7 & 70.8 & 62.9 & 77.7 & 36.1 & 39.4 & 37.6 & 40.4 \\
\hline Kusini Pemba & 59.6 & * & 60.2 & 60.5 & 78.2 & * & 78.9 & 89.2 & 49.1 & * & 50 & 56.1 \\
\hline Mainland & 72 & 75.4 & 73.4 & 80 & 74.6 & 84.2 & 78.4 & 88.3 & 58.4 & 66.2 & 61.5 & 73.9 \\
\hline Zanzibar & 45.4 & 48.4 & 46.6 & 43.1 & 81.2 & 75.9 & 79.1 & 82.2 & 36.2 & 43.3 & 39 & 39.3 \\
\hline Urban & 74.1 & 67 & 71 & 81.5 & 85.2 & 88.6 & 86.7 & 92.8 & 66.6 & 61.6 & 64.4 & 77.3 \\
\hline Rural & 70.2 & 76.9 & 72.8 & 77.4 & 71.9 & 82.3 & 75.9 & 86 & 55 & 66.7 & 59.5 & 70.6 \\
\hline National & 71 & 74.4 & 72.4 & 78.6 & 74.9 & 83.9 & 78.5 & 88 & 57.5 & 65.4 & 60.7 & 72.6 \\
\hline
\end{tabular}

a Using condoms every time they have sexual intercourse; b partner who has no other partners. 


\begin{tabular}{|c|c|c|c|c|c|c|c|c|c|c|c|c|c|c|c|c|}
\hline \multirow[t]{2}{*}{ Region } & \multicolumn{4}{|c|}{$\begin{array}{l}\text { A healthy-looking person can } \\
\text { have the AIDS virus }\end{array}$} & \multicolumn{4}{|c|}{$\begin{array}{l}\text { AIDS cannot be transmitted by } \\
\text { mosquito bites }{ }^{b}\end{array}$} & \multicolumn{4}{|c|}{$\begin{array}{l}\text { AIDS cannot be transmitted by } \\
\text { supernatural means }{ }^{b}\end{array}$} & \multicolumn{4}{|c|}{$\begin{array}{c}\text { Percent with a } \\
\text { comprehensive knowledge } \\
\text { about HIV/AIDS }\end{array}$} \\
\hline & $\begin{array}{l}15-17 \\
\text { years }\end{array}$ & $\begin{array}{l}18-19 \\
\text { years }\end{array}$ & $\begin{array}{l}15-19 \\
\text { years }\end{array}$ & $\begin{array}{l}20-24 \\
\text { years }\end{array}$ & $\begin{array}{l}15-17 \\
\text { years }\end{array}$ & $\begin{array}{l}18-19 \\
\text { years }\end{array}$ & $\begin{array}{c}15- \\
19 \\
\text { years }\end{array}$ & $\begin{array}{c}20- \\
24 \\
\text { years }\end{array}$ & $\begin{array}{c}15- \\
17 \\
\text { years }\end{array}$ & $\begin{array}{c}18- \\
19 \\
\text { years }\end{array}$ & $\begin{array}{c}15- \\
19 \\
\text { years }\end{array}$ & $\begin{array}{c}20- \\
24 \\
\text { years }\end{array}$ & $\begin{array}{c}15- \\
17 \\
\text { years }\end{array}$ & $\begin{array}{c}18- \\
19 \\
\text { years }\end{array}$ & $\begin{array}{c}15- \\
19 \\
\text { years }\end{array}$ & $\begin{array}{c}20- \\
24 \\
\text { years }\end{array}$ \\
\hline \multicolumn{17}{|l|}{ Mainland } \\
\hline Arusha & 87.2 & 92.1 & 89 & 70.7 & 78.1 & 80.7 & 79.1 & 68.5 & 76.8 & 86.7 & 80.4 & 90 & 33.5 & 53.6 & 40.8 & 37.1 \\
\hline Dar es Salaam & 86.4 & 83.4 & 85.4 & 93.9 & 91.3 & 92.1 & 91.6 & 91.1 & 88.1 & 89.9 & 88.7 & 79.6 & 51.2 & 60.5 & 54.2 & 55.8 \\
\hline Dodoma & 80 & * & 85 & 84.5 & 85.1 & * & 86.4 & 62.3 & 85.6 & * & 87.4 & 94.2 & 59.1 & * & 65 & 56.4 \\
\hline Iringa & 76.8 & 81.7 & 78.8 & 69.5 & 90 & 68.8 & 81.2 & 78.3 & 91.3 & 95 & 92.8 & 91.1 & 33.9 & 44.2 & 38.2 & 46.1 \\
\hline Kagera & 75.2 & 78 & 76.2 & 79.6 & 92.4 & 81.8 & 88.4 & 88.8 & 83.3 & 84.3 & 83.7 & 90 & 51.7 & 54.7 & 52.8 & 61.9 \\
\hline Kigoma & 78.4 & * & 80.8 & 80.6 & 90 & * & 89.5 & 83.5 & 87.1 & * & 87.1 & 72.4 & 43.8 & 44.2 & 43.9 & 37.9 \\
\hline Kilimanjaro & 82.6 & * & 83.9 & 88.5 & 92.3 & * & 87.6 & 82.5 & 92 & * & 93.1 & 80.8 & 43.7 & * & 45.9 & 52.6 \\
\hline Lindi & * & * & 86.6 & 91.8 & * & * & 86.5 & 81.5 & * & * & 84.3 & 91.1 & * & * & 53.3 & 64.4 \\
\hline Manyara & 70.3 & 85.4 & 76.3 & 70.3 & 84.5 & 87.9 & 85.8 & 85.6 & 80.2 & 97.4 & 87 & 75.9 & 30.2 & 64 & 42.9 & 44.2 \\
\hline Mara & 80.7 & 79.2 & 80.2 & 93.2 & 81 & 88.9 & 83.8 & 77.9 & 83.3 & 81.4 & 82.6 & 84.2 & 39 & 33.7 & 37.1 & 40.5 \\
\hline Mbeya & 76.1 & * & 80.9 & 86.2 & 92 & * & 88.9 & 82 & 90.1 & * & 92.2 & 91.4 & 47.7 & * & 48.4 & 58.2 \\
\hline Morogoro & 91.9 & 80.9 & 86.4 & 90.3 & 94.2 & 82.5 & 88.4 & 81.3 & 89.4 & 85.5 & 87.4 & 83.8 & 56.8 & 49.1 & 53 & 54.4 \\
\hline Mtwara & 79 & * & 78.5 & 97.8 & 85.4 & * & 83.3 & 84.6 & 97.7 & * & 96.4 & 93 & 57.5 & * & 57 & 71.4 \\
\hline Mwanza & 70.2 & 90.5 & 77.5 & 81.9 & 73.7 & 75.9 & 74.5 & 79.5 & 83.4 & 93.8 & 87.1 & 77.9 & 13.3 & 33.9 & 20.6 & 31.4 \\
\hline Pwani & 100 & * & 94.3 & 94 & 87 & * & 74.8 & 69.2 & 97.4 & * & 93.5 & 89.7 & 77.9 & * & 69.4 & 47.1 \\
\hline Rukwa & 77.6 & * & 81.4 & 85.8 & 88.2 & * & 84.8 & 76.4 & 89.9 & * & 89.6 & 87.7 & 45.5 & * & 48.3 & 50.7 \\
\hline Ruvuma & 69.8 & * & 72.2 & 83 & 75.1 & * & 80.6 & 77.9 & 91.4 & * & 87.3 & 79 & 28.7 & * & 31.6 & 45.4 \\
\hline Shinyanga & 81.6 & 83.1 & 82.3 & 93.9 & 82.5 & 91.1 & 86.3 & 84.6 & 83.1 & 82.3 & 82.8 & 81.4 & 50.9 & 59.3 & 54.5 & 56.5 \\
\hline Singida & 77.5 & * & 74.6 & 70.9 & 84.4 & * & 85.7 & 92.9 & 84.2 & * & 84.1 & 91.6 & 46.9 & * & 47.1 & 44.9 \\
\hline Tabora & 86.9 & 90.1 & 88.2 & 90.3 & 86.2 & 75.2 & 81.9 & 83.7 & 95.4 & 93.6 & 94.7 & 81 & 54.6 & 54.1 & 54.4 & 62.5 \\
\hline Tanga & 83.5 & * & 84.8 & 76 & 94.4 & * & 91.2 & 82.7 & 88.9 & * & 88.9 & 81.8 & 45.4 & * & 44.9 & 52.7 \\
\hline
\end{tabular}




\begin{tabular}{|c|c|c|c|c|c|c|c|c|c|c|c|c|c|c|c|c|}
\hline \multirow[t]{2}{*}{ Region } & \multicolumn{4}{|c|}{$\begin{array}{l}\text { A healthy-looking person can } \\
\text { have the AIDS virus }\end{array}$} & \multicolumn{4}{|c|}{$\begin{array}{l}\text { AIDS cannot be transmitted by } \\
\text { mosquito bites }{ }^{b}\end{array}$} & \multicolumn{4}{|c|}{$\begin{array}{l}\text { AIDS cannot be transmitted by } \\
\text { supernatural means }{ }^{b}\end{array}$} & \multicolumn{4}{|c|}{$\begin{array}{c}\text { Percent with a } \\
\text { comprehensive knowledgea } \\
\text { about HIV/AIDS }\end{array}$} \\
\hline & $\begin{array}{l}15-17 \\
\text { years }\end{array}$ & $\begin{array}{l}18-19 \\
\text { years }\end{array}$ & $\begin{array}{l}15-19 \\
\text { years }\end{array}$ & $\begin{array}{l}20-24 \\
\text { years }\end{array}$ & $\begin{array}{l}15-17 \\
\text { years }\end{array}$ & $\begin{array}{l}18-19 \\
\text { years }\end{array}$ & $\begin{array}{c}15- \\
19 \\
\text { years }\end{array}$ & $\begin{array}{c}20- \\
24 \\
\text { years }\end{array}$ & $\begin{array}{c}15- \\
17 \\
\text { years }\end{array}$ & $\begin{array}{c}18- \\
19 \\
\text { years }\end{array}$ & $\begin{array}{c}15- \\
19 \\
\text { years }\end{array}$ & $\begin{array}{c}20- \\
24 \\
\text { years }\end{array}$ & $\begin{array}{c}15- \\
17 \\
\text { years }\end{array}$ & $\begin{array}{c}18- \\
19 \\
\text { years }\end{array}$ & $\begin{array}{c}15- \\
19 \\
\text { years }\end{array}$ & $\begin{array}{c}20- \\
24 \\
\text { years }\end{array}$ \\
\hline \multicolumn{17}{|l|}{ Zanzibar } \\
\hline $\begin{array}{l}\text { Kaskazini } \\
\text { Unguja }\end{array}$ & 83.7 & 84.5 & 84 & 82.2 & 81.2 & 81.1 & 81.2 & 68.2 & 71.6 & 79.3 & 74.6 & 71.8 & 19.3 & 26.2 & 21.9 & 28.5 \\
\hline Kusini Unguja & 86.6 & 85 & 85.9 & 91.6 & 81.5 & 83.6 & 82.4 & 77.5 & 70.3 & 75.9 & 72.5 & 75.3 & 34.2 & 39.8 & 36.4 & 37.7 \\
\hline $\begin{array}{c}\text { Mjini } \\
\text { Magharibi }\end{array}$ & 89.2 & 91.5 & 90.1 & 95.4 & 95.5 & 91.7 & 94 & 94.8 & 75.9 & 76.3 & 76.1 & 78.2 & 32.7 & 44.2 & 37.2 & 48.1 \\
\hline $\begin{array}{c}\text { Kaskazini } \\
\text { Pemba }\end{array}$ & 72 & 76.8 & 73.6 & 83.5 & 72.3 & 72.2 & 72.2 & 63.8 & 68.3 & 86.1 & 74.5 & 74.3 & 15.3 & 44.7 & 25.4 & 27.7 \\
\hline Kusini Pemba & 72.9 & 77.9 & 74.6 & 88 & 86.9 & 78.2 & 83.9 & 74.4 & 69 & 71.1 & 69.7 & 70.6 & 24.5 & 30.7 & 26.6 & 35.2 \\
\hline Mainlalnd & 80.1 & 84.9 & 81.8 & 85.2 & 86.3 & 82.9 & 85.1 & 81.6 & 87.2 & 88.9 & 87.8 & 84.2 & 44.5 & 51.3 & 46.9 & 50.8 \\
\hline Zanzibar & 81.2 & 84.6 & 82.4 & 89.7 & 85.5 & 83.1 & 84.6 & 80.6 & 71.8 & 77.6 & 74 & 75 & 25.4 & 38.4 & 30.2 & 38.6 \\
\hline Urban & 88.7 & 87.2 & 88.2 & 92.2 & 90.4 & 89.7 & 79.4 & 85.3 & 89.4 & 92.8 & 90.6 & 85.1 & 50.1 & 59.5 & 53.5 & 56 \\
\hline Rural & 76.5 & 83.9 & 79.1 & 82 & 84.5 & 80.1 & 90.2 & 79.6 & 85.5 & 86.6 & 85.9 & 83.3 & 41.1 & 47.1 & 43.3 & 47.7 \\
\hline National & 80.1 & 84.9 & 81.8 & 85.4 & 86.3 & 82.9 & 85.1 & 81.5 & 86.6 & 88.4 & 87.3 & 83.9 & 43.8 & 50.8 & 46.3 & 50.4 \\
\hline
\end{tabular}

a Comprehensive knowledge: knowing consistent use of a condom during sexual intercourse and having just one

uninfected faithful partner can reduce the change of getting AIDS, knowing a healthy-looking person can have

AIDS virus, and rejecting the two most common local misconceptions about AIDS.

b Two most common local misconceptions: 'AIDS can be transmitted by mosquito bites' or by 'supernatural means'. 


\begin{tabular}{|c|c|c|c|c|c|c|c|c|c|c|c|c|c|c|c|c|}
\hline \multicolumn{17}{|c|}{ Table 34A-2: Percent of Males Ages 15-24 Who Have Comprehensive Knowledge about HIV/AIDS (DHS 2010) } \\
\hline \multirow[t]{2}{*}{ Region } & \multicolumn{4}{|c|}{$\begin{array}{c}\text { A healthy-looking person can } \\
\text { have the AIDS virus }\end{array}$} & \multicolumn{4}{|c|}{$\begin{array}{l}\text { AIDS cannot be transmitted by } \\
\text { mosquito bites }{ }^{b}\end{array}$} & \multicolumn{4}{|c|}{$\begin{array}{l}\text { AIDS cannot be transmitted by } \\
\text { supernatural means }{ }^{b}\end{array}$} & \multicolumn{4}{|c|}{$\begin{array}{c}\text { Percent with a } \\
\text { comprehensive knowledge }^{a} \\
\text { about HIV/AIDS }\end{array}$} \\
\hline & $\begin{array}{l}15-17 \\
\text { years }\end{array}$ & $\begin{array}{l}18-19 \\
\text { years }\end{array}$ & $\begin{array}{l}15-19 \\
\text { years }\end{array}$ & $\begin{array}{l}20-24 \\
\text { years }\end{array}$ & $\begin{array}{l}15-17 \\
\text { years }\end{array}$ & $\begin{array}{l}18-19 \\
\text { years }\end{array}$ & $\begin{array}{c}15- \\
19 \\
\text { years }\end{array}$ & $\begin{array}{c}20- \\
24 \\
\text { years }\end{array}$ & $\begin{array}{c}15- \\
17 \\
\text { years }\end{array}$ & $\begin{array}{c}18- \\
19 \\
\text { years }\end{array}$ & $\begin{array}{c}15- \\
19 \\
\text { years }\end{array}$ & $\begin{array}{c}20- \\
24 \\
\text { years }\end{array}$ & $\begin{array}{c}15- \\
17 \\
\text { years }\end{array}$ & $\begin{array}{c}18- \\
19 \\
\text { years }\end{array}$ & $\begin{array}{c}15- \\
19 \\
\text { years }\end{array}$ & $\begin{array}{c}20- \\
24 \\
\text { years }\end{array}$ \\
\hline \multicolumn{17}{|l|}{ Mainland } \\
\hline Arusha & * & * & * & * & * & * & * & * & * & * & * & * & * & * & * & * \\
\hline Dar es Salaam & * & * & 93.6 & * & * & * & 88.1 & * & * & * & 90.4 & * & * & * & 52.9 & * \\
\hline Dodoma & * & * & * & * & * & * & * & * & * & * & * & * & * & * & * & * \\
\hline Iringa & * & * & 88.2 & * & * & * & 88 & * & * & * & 88.4 & * & * & * & 39 & * \\
\hline Kagera & * & * & 72.4 & * & * & * & 82.4 & * & * & * & 88.4 & * & * & * & 36.5 & * \\
\hline Kigoma & * & * & * & * & * & * & * & * & * & * & * & * & * & * & * & * \\
\hline Kilimanjaro & * & * & 85 & * & * & * & 82.3 & * & * & * & 85.7 & * & * & * & 43.6 & * \\
\hline Lindi & * & * & * & * & * & * & * & * & * & * & * & * & * & * & * & * \\
\hline Manyara & * & * & * & * & * & * & * & * & * & * & * & * & * & * & * & * \\
\hline Mara & * & * & 93.8 & * & * & * & 69.7 & * & * & * & 93.8 & * & * & * & 32.8 & * \\
\hline Mbeya & * & * & 60.7 & * & * & * & 77 & * & * & * & 98.7 & * & * & * & 31.6 & * \\
\hline Morogoro & * & * & 82 & * & * & * & 70 & * & * & * & 86.7 & * & * & * & 35.4 & * \\
\hline Mtwara & * & * & * & * & * & * & * & * & * & * & * & * & * & * & * & * \\
\hline Mwanza & 75.2 & * & 75.9 & 80.6 & 62 & * & 58.5 & 51.4 & 94.6 & * & 96.3 & 100 & 30.8 & * & 31.3 & 34.7 \\
\hline Pwani & * & * & * & * & * & * & * & * & * & * & * & * & * & * & * & * \\
\hline Rukwa & * & * & * & * & * & * & * & * & * & * & * & * & * & * & * & * \\
\hline Ruvuma & * & * & * & * & * & * & * & * & * & * & * & * & * & * & * & * \\
\hline Shinyanga & * & * & 52.7 & * & * & * & 82.6 & * & * & * & 72.1 & * & * & * & 39.7 & * \\
\hline Singida & * & * & 92.2 & * & * & * & 75.2 & * & * & * & 93.9 & * & * & * & 51.3 & $\star$ \\
\hline Tabora & * & * & 62.2 & * & * & * & 75.7 & * & * & * & 91.2 & * & * & * & 48.2 & * \\
\hline Tanga & * & * & * & * & * & * & * & * & * & * & * & * & * & * & * & * \\
\hline
\end{tabular}




\begin{tabular}{|c|c|c|c|c|c|c|c|c|c|c|c|c|c|c|c|c|}
\hline \multirow[t]{2}{*}{ Region } & \multicolumn{4}{|c|}{$\begin{array}{c}\text { A healthy-looking person can } \\
\text { have the AIDS virus }\end{array}$} & \multicolumn{4}{|c|}{$\begin{array}{l}\text { AIDS cannot be transmitted by } \\
\text { mosquito } \text { bites }^{b}\end{array}$} & \multicolumn{4}{|c|}{$\begin{array}{l}\text { AIDS cannot be transmitted by } \\
\text { supernatural means }{ }^{b}\end{array}$} & \multicolumn{4}{|c|}{$\begin{array}{c}\text { Percent with a } \\
\text { comprehensive knowledge } \\
\text { about HIV/AIDS }\end{array}$} \\
\hline & $\begin{array}{l}15-17 \\
\text { years }\end{array}$ & $\begin{array}{l}18-19 \\
\text { years }\end{array}$ & $\begin{array}{l}15-19 \\
\text { years }\end{array}$ & $\begin{array}{l}20-24 \\
\text { years }\end{array}$ & $\begin{array}{l}15-17 \\
\text { years }\end{array}$ & $\begin{array}{l}18-19 \\
\text { years }\end{array}$ & $\begin{array}{c}15- \\
19 \\
\text { years }\end{array}$ & $\begin{array}{c}20- \\
24 \\
\text { years }\end{array}$ & $\begin{array}{c}15- \\
17 \\
\text { years }\end{array}$ & $\begin{array}{c}18- \\
19 \\
\text { years }\end{array}$ & $\begin{array}{c}15- \\
19 \\
\text { years }\end{array}$ & $\begin{array}{c}20- \\
24 \\
\text { years }\end{array}$ & $\begin{array}{c}15- \\
17 \\
\text { years }\end{array}$ & $\begin{array}{c}18- \\
19 \\
\text { years }\end{array}$ & $\begin{array}{c}15- \\
19 \\
\text { years }\end{array}$ & $\begin{array}{c}20- \\
24 \\
\text { years }\end{array}$ \\
\hline \multicolumn{17}{|l|}{ Zanzibar } \\
\hline $\begin{array}{l}\text { Kaskazini } \\
\text { Unguja }\end{array}$ & 56.2 & * & 66.1 & * & 65.7 & * & 70.4 & * & 68.1 & * & 68.7 & * & 13.7 & * & 18.2 & * \\
\hline Kusini Unguja & * & * & 89.7 & 83.6 & * & * & 92.4 & 97.1 & * & * & 91.8 & 94.2 & * & * & 31.7 & 48.9 \\
\hline $\begin{array}{c}\text { Mjini } \\
\text { Magharibi }\end{array}$ & * & * & 93.6 & * & * & * & 85.9 & * & * & * & 89.2 & * & * & * & 35.5 & * \\
\hline $\begin{array}{l}\text { Kaskazini } \\
\text { Pemba }\end{array}$ & * & * & 76.5 & * & * & * & 83.7 & * & * & * & 88.4 & * & * & * & 18.3 & * \\
\hline Kusini Pemba & * & * & 84.7 & 96.2 & $\star$ & * & 93.2 & 86.7 & * & * & 96.3 & 86.7 & * & * & 21.4 & 26.4 \\
\hline Mainland & 77.3 & 84.3 & 79.9 & 88.9 & 75.5 & 80.3 & 77.3 & 76.1 & 88.7 & 91.1 & 89.6 & 89.4 & 37.1 & 48.6 & 41.4 & 45.8 \\
\hline Zanzibar & 82.2 & 85.7 & 83.7 & 93 & 80.2 & 90.7 & 84.5 & 87.6 & 84.4 & 90 & 86.7 & 86.6 & 27.2 & 25.7 & 26.6 & 34.9 \\
\hline Urban & 82 & 98.4 & 89.2 & 93.8 & 87.3 & 94.9 & 90.6 & 80.5 & 91.3 & 93 & 92 & 96.8 & 54.3 & 67.5 & 60.1 & 52.8 \\
\hline Rural & 76.1 & 78.5 & 77 & 87 & 72.2 & 74.8 & 73.1 & 74.8 & 87.7 & 90.3 & 88.6 & 86.2 & 31.6 & 39.6 & 34.5 & 42.3 \\
\hline National & 77.4 & 84.3 & 80 & 89 & 75.6 & 80.7 & 77.5 & 76.5 & 88.5 & 91.1 & 89.5 & 89.3 & 36.8 & 47.8 & 40.9 & 45.4 \\
\hline
\end{tabular}


Table 34B-1: Percent of Females Ages 15-24 Who Have Comprehensive Knowledge about HIV/AIDS (THMIS 2011-2012)

\begin{tabular}{|c|c|c|c|c|c|c|c|c|c|c|c|c|c|c|c|c|}
\hline \multirow{2}{*}{ Region } & \multicolumn{4}{|c|}{$\begin{array}{l}\text { A healthy-looking person can } \\
\text { have the AIDS virus }\end{array}$} & \multicolumn{4}{|c|}{$\begin{array}{c}\text { AIDS cannot be transmitted by } \\
\text { mosquito bites }{ }^{\mathrm{b}}\end{array}$} & \multicolumn{4}{|c|}{$\begin{array}{l}\text { AIDS cannot be transmitted by } \\
\text { supernatural means }{ }^{b}\end{array}$} & \multicolumn{4}{|c|}{$\begin{array}{c}\text { Percent with a } \\
\text { comprehensive knowledgea } \\
\text { about HIV/AIDS }\end{array}$} \\
\hline & -17 & & & & $\begin{array}{l}15-17 \\
\text { years }\end{array}$ & & $\begin{array}{c}15- \\
19 \\
\text { years }\end{array}$ & $\begin{array}{c}20- \\
24 \\
\text { years }\end{array}$ & $\begin{array}{c}15- \\
17 \\
\text { years }\end{array}$ & $\begin{array}{c}18- \\
19 \\
\text { years }\end{array}$ & $\begin{array}{c}15- \\
19 \\
\text { years }\end{array}$ & $\begin{array}{c}20- \\
24 \\
\text { years }\end{array}$ & $\begin{array}{c}15- \\
17 \\
\text { years }\end{array}$ & $\begin{array}{c}18- \\
19 \\
\text { years }\end{array}$ & $\begin{array}{c}15- \\
19 \\
\text { years }\end{array}$ & $\begin{array}{c}20- \\
24 \\
\text { years }\end{array}$ \\
\hline \multicolumn{17}{|l|}{ Mainland } \\
\hline Arusha & .9 & ${ }^{*}$ & .3 & 14 & .5 & * & 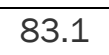 & 19 & 93.1 & * & 4.2 & 79 & 54 & 52.5 & 53.5 & 29.7 \\
\hline Dar es Salaam & 71.2 & 88.5 & 78.8 & 88.7 & 93.3 & 90.6 & 92.1 & 93.1 & 85.9 & 93.4 & 89.2 & 89.2 & 42.8 & 52.1 & 46.9 & 65.7 \\
\hline Dodoma & * & * & 78.7 & 71 & * & * & 86 & 70.1 & * & * & 98 & 81.2 & * & * & 39.4 & 38.3 \\
\hline eita & 58.1 & 59.6 & 58.6 & 76 & 82.7 & 91.6 & 85.5 & 80.2 & 81.4 & 85 & 82.6 & 85.1 & 22.5 & 33.6 & 26 & 40.1 \\
\hline Iringa & 89.6 & 84 & 86.3 & 88.7 & 77.1 & 91.7 & 85.5 & 93.4 & 100 & 97.1 & 98.3 & 97.6 & 34.3 & 50.8 & 43.8 & 64.4 \\
\hline Kagera & 71.1 & 78.6 & 73.8 & 84.6 & 92.7 & 84.3 & 89.6 & 85.9 & 97.4 & 100 & 98.4 & 98.1 & 42 & 42.3 & 42.1 & 53.2 \\
\hline Katavi & 3.1 & 92 & 5.9 & 83.4 & 77.2 & 1.5 & $83.3^{3}-x$ & 70.6 & 77.8 & 89.3 & 82.7 & 79.9 & 16.6 & 49 & 29.6 & 30.5 \\
\hline Kigoma & 9.1 & 76.4 & 6.4 & 80 & 81 & 91.9 & 85.6 & 76.9 & 92.5 & 87.3 & 90.3 & 89.7 & 24.9 & 34.7 & 29 & 34.2 \\
\hline Kilimanjaro & 82.9 & 91.2 & 86.2 & 86.5 & 91.5 & 75.6 & 85.1 & 80.8 & 100 & 94.9 & 97.9 & 92 & 26.9 & 27.6 & 27.2 & 46 \\
\hline Lindi & 67.8 & * & 73 & 82.5 & 82.7 & * & 87.9 & 81.5 & 84 & * & 87.1 & 83.2 & 44.3 & * & 52.9 & 53.7 \\
\hline Manyara & 67.5 & 67.2 & 67.4 & 84.8 & 81.4 & 76.3 & 79.8 & 81.5 & 89.8 & 86.7 & 88.9 & 92.1 & 29.7 & 42.7 & 33.7 & 52.6 \\
\hline Mara & 79.5 & 79.4 & 5 & 81.9 & 78.3 & 76.3 & 77.5 & 76.7 & 88.2 & 89.8 & 88.9 & 89.6 & 27.4 & 32.5 & 29.5 & 40.3 \\
\hline Mbeya & 76.5 & 88.7 & 81.5 & 80.4 & 86.5 & 87.8 & 87 & 85.5 & 89.5 & 97.9 & 92.9 & 84.5 & 24.6 & 35 & 28.8 & 29.3 \\
\hline Morogoro & 66.4 & 73.8 & 0.5 & 70.7 & 85 & 86.6 & 85.9 & 86 & 95.2 & 92.7 & 93.8 & 87 & 56.6 & 56.9 & 56.8 & 51.6 \\
\hline Mtwara & 70.9 & * & 76.4 & 77 & 87.2 & * & 85.6 & 92.7 & 91 & * & 88.4 & 89.5 & 43.5 & * & 48.5 & 54.4 \\
\hline Mwanza & 56.7 & 74.7 & 63.4 & 78.8 & 93.9 & 79.5 & 88.5 & 78.4 & 92.5 & 83.6 & 89.2 & 89.2 & 29.9 & 37.1 & 32.6 & 40.4 \\
\hline Njombe & 66.7 & * & 72.3 & 73.8 & 88 & * & 90.4 & 70.7 & 70.4 & * & 70 & 91 & 35.2 & * & 38.5 & 38.8 \\
\hline Pwani & 80 & * & 84.5 & 91.1 & 92.7 & * & 94.3 & 80.9 & 97.5 & * & 97.5 & 93.1 & 61.8 & * & 69.3 & 54.2 \\
\hline Rukwa & 76.6 & * & 81.4 & 8 & 67.7 & * & 82.2 & 79.5 & 85 & 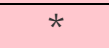 & 91.7 & 86.4 & 25.5 & * & 33.8 & 38.4 \\
\hline Ruvuma & 70.2 & 84.5 & 75.9 & 83.1 & 88.7 & 72 & 02 & 78.2 & 88.1 & 81.3 & 85.3 & 91.8 & 47.1 & 46 & 46.7 & 38.2 \\
\hline Shinyanga & 51.8 & 63.7 & 56.6 & 66 & 78.5 & 83.4 & 80.5 & 84.3 & 89 & 96.3 & 91.9 & 89.1 & 25.5 & 42 & 32.1 & 46.8 \\
\hline Simiyu & 71.9 & 69.6 & 70.9 & 76.7 & 68.9 & 64.6 & 67.1 & 71.9 & 85.5 & 79.3 & 82.9 & 72.4 & 11.3 & 15.8 & 13.1 & 24.5 \\
\hline Singida & 64.6 & 85.1 & 73.2 & 74.3 & 83.4 & 92 & 87 & 91.3 & 93.9 & 96.2 & 94.8 & 85.6 & 38.7 & 58.3 & 46.6 & 48.8 \\
\hline Tabora & 84.3 & 86.8 & 85.3 & 77.5 & 85.4 & 86.2 & 85.7 & 87.2 & 93.9 & 85.4 & 90.8 & 92.9 & 53.4 & 68.1 & 58.8 & 54.8 \\
\hline Tanga & 80.4 & 85.4 & 82.6 & 60 & 80.1 & 87.4 & 83.3 & 75 & 86.6 & 95.3 & 90.3 & 83.4 & 28.2 & 24 & 26.3 & 28.5 \\
\hline
\end{tabular}




\begin{tabular}{|c|c|c|c|c|c|c|c|c|c|c|c|c|c|c|c|c|}
\hline \multirow{2}{*}{ Region } & \multicolumn{4}{|c|}{$\begin{array}{l}\text { A healthy-looking person can } \\
\text { have the AIDS virus }\end{array}$} & \multicolumn{4}{|c|}{$\begin{array}{l}\text { AIDS cannot be transmitted by } \\
\text { mosquito bites }{ }^{b}\end{array}$} & \multicolumn{4}{|c|}{$\begin{array}{l}\text { AIDS cannot be transmitted by } \\
\text { supernatural means }{ }^{b}\end{array}$} & \multicolumn{4}{|c|}{$\begin{array}{c}\text { Percent with a } \\
\text { comprehensive knowledgea } \\
\text { about HIV/AIDS }\end{array}$} \\
\hline & $\begin{array}{l}15-17 \\
\text { years }\end{array}$ & $\begin{array}{l}18-19 \\
\text { years }\end{array}$ & $\begin{array}{l}15-19 \\
\text { years }\end{array}$ & $\begin{array}{l}20-24 \\
\text { years }\end{array}$ & $\begin{array}{l}15-17 \\
\text { years }\end{array}$ & $\begin{array}{l}18-19 \\
\text { years }\end{array}$ & $\begin{array}{c}15- \\
19 \\
\text { years }\end{array}$ & $\begin{array}{c}20- \\
24 \\
\text { years }\end{array}$ & $\begin{array}{c}15- \\
17 \\
\text { years }\end{array}$ & $\begin{array}{c}18- \\
19 \\
\text { years }\end{array}$ & $\begin{array}{c}15- \\
19 \\
\text { years }\end{array}$ & $\begin{array}{c}20- \\
24 \\
\text { years }\end{array}$ & $\begin{array}{c}15- \\
17 \\
\text { years }\end{array}$ & $\begin{array}{c}18- \\
19 \\
\text { years }\end{array}$ & $\begin{array}{c}15- \\
19 \\
\text { years }\end{array}$ & $\begin{array}{c}20- \\
24 \\
\text { years }\end{array}$ \\
\hline \multicolumn{17}{|l|}{ Zanzibar } \\
\hline $\begin{array}{c}\text { Kaskazini } \\
\text { Unguja }\end{array}$ & 81.6 & 90.1 & 84.6 & 90 & 83.5 & 76.2 & 81 & 81.3 & 59.3 & 65.4 & 61.4 & 70.3 & 16.4 & 14 & 15.5 & 28.7 \\
\hline Kusini Unguja & 92.1 & * & 93.9 & 93 & 89.2 & * & 88.5 & 86.6 & 76.6 & * & 72.3 & 76.9 & 39.7 & * & 34.1 & 36.1 \\
\hline $\begin{array}{c}\text { Mjini } \\
\text { Magharibi }\end{array}$ & 98.1 & 95.3 & 96.9 & 97.5 & 91.9 & 85.5 & 89.1 & 89.9 & 70.8 & 80.4 & 75 & 74.4 & 11.3 & 41.2 & 24.4 & 46.5 \\
\hline $\begin{array}{c}\text { Kaskazini } \\
\text { Pemba }\end{array}$ & 88.6 & 86.8 & 87.9 & 85.3 & 81.7 & 87.8 & 83.9 & 78.8 & 54.6 & 67.3 & 59.3 & 72.7 & 29.7 & 35.9 & 32 & 39 \\
\hline Kusini Pemba & 88.5 & 95.8 & 91.3 & 97.2 & 95.3 & 81.9 & 90.1 & 82 & 82.4 & 85.1 & 83.4 & 76.3 & 43.8 & 39.9 & 42.3 & 39.9 \\
\hline Mainland & 71.6 & 80.4 & 75.2 & 78.7 & 84.5 & 83.9 & 84.3 & 82.2 & 89.8 & 90.2 & 90 & 87.6 & 34 & 42 & 37.2 & 44.3 \\
\hline Zanzibar & 93.4 & 93.9 & 93.6 & 95 & 89.7 & 84.7 & 87.7 & 86.3 & 68.8 & 77.2 & 72.3 & 74.1 & 20 & 37.2 & 27.1 & 42.1 \\
\hline Urban & 77.7 & 87.7 & 81.5 & 87.2 & 90 & 90.3 & 90.1 & 87.3 & 93.1 & 93.4 & 93.2 & 88.4 & 45.6 & 58.5 & 50.5 & 53.6 \\
\hline Rural & 70.4 & 78.7 & 73.8 & 76.4 & 82.7 & 81.7 & 82.3 & 80.6 & 87.4 & 88.4 & 87.8 & 86.5 & 28.7 & 36.2 & 31.8 & 40.7 \\
\hline National & 72.5 & 81 & 75.9 & 79.3 & 84.7 & 83.9 & 84.4 & 82.4 & 89 & 89.7 & 89.3 & 87 & 33.4 & 41.8 & 36.8 & 44.2 \\
\hline
\end{tabular}




\begin{tabular}{|c|c|c|c|c|c|c|c|c|c|c|c|c|c|c|c|c|}
\hline \multirow{2}{*}{ Region } & \multicolumn{4}{|c|}{$\begin{array}{l}\text { A healthy-looking person can } \\
\text { have the AIDS virus }\end{array}$} & \multicolumn{4}{|c|}{$\begin{array}{l}\text { AIDS cannot be transmitted by } \\
\text { mosquito bites }{ }^{b}\end{array}$} & \multicolumn{4}{|c|}{$\begin{array}{l}\text { AIDS cannot be transmitted by } \\
\text { supernatural means }{ }^{b}\end{array}$} & \multicolumn{4}{|c|}{$\begin{array}{c}\text { Percent with a } \\
\text { comprehensive knowledge } \\
\text { about HIV/AIDS }\end{array}$} \\
\hline & $\begin{array}{l}15-17 \\
\text { years }\end{array}$ & $\begin{array}{l}18-19 \\
\text { years }\end{array}$ & $15-19$ & $\begin{array}{l}20-24 \\
\text { years }\end{array}$ & $\begin{array}{l}15-17 \\
\text { years }\end{array}$ & & $\begin{array}{c}15- \\
19 \\
\text { years }\end{array}$ & $\begin{array}{c}20- \\
24 \\
\text { years }\end{array}$ & $\begin{array}{c}15- \\
17 \\
\text { years }\end{array}$ & $\begin{array}{c}18- \\
19 \\
\text { years }\end{array}$ & $\begin{array}{c}15- \\
19 \\
\text { years }\end{array}$ & $\begin{array}{c}20- \\
24 \\
\text { years }\end{array}$ & $\begin{array}{c}15- \\
17 \\
\text { years }\end{array}$ & $\begin{array}{c}18- \\
19 \\
\text { years }\end{array}$ & $\begin{array}{c}15- \\
19 \\
\text { years }\end{array}$ & $\begin{array}{c}20- \\
24 \\
\text { years }\end{array}$ \\
\hline \multicolumn{17}{|l|}{ Mainland } \\
\hline Arusha & 8.5 & * & 62 & 97.5 & 68.7 & * & 73.3 & 98.1 & 73.3 & * & 71.1 & 83.7 & 27.5 & * & 36.9 & 71.2 \\
\hline Dar es Salaam & 88.3 & 97.7 & 92.9 & 98 & 96 & 86.1 & 91.2 & 4.9 & 100 & 93.5 & 6.8 & 88.3 & 62.1 & 51 & 56.7 & 63.9 \\
\hline Dodoma & 52.9 & * & 69.3 & 84.6 & 91.9 & * & 82.2 & 60.6 & 88.6 & * & 89.5 & 83.5 & 43.9 & * & 41.2 & 33.1 \\
\hline Geita & 72.2 & 79.5 & 74.9 & 90.9 & 4.1 & 87.7 & 79.1 & 75.9 & 82.3 & 94.8 & 86.9 & 87.3 & 24.2 & 30.9 & 26.7 & 43.4 \\
\hline Iringa & 84.8 & 77.5 & 81.8 & 81.2 & 89.1 & 95.1 & 91.5 & 91.9 & 94.5 & 91.6 & 93.3 & 92.6 & 74 & 62.5 & 69.2 & 58.9 \\
\hline Kagera & 81.1 & * & 82 & 84.2 & 73 & 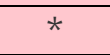 & 73 & 90.4 & 95 & * & 9 & 96.7 & 31.3 & * & 32.9 & 52 \\
\hline Katavi & 9.5 & * & 86.1 & $0 . c^{2}-x$ & 93.5 & * & 94. & 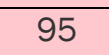 & 91 & * & 90 & 89.4 & 52.9 & * & 61.6 & 71.6 \\
\hline Kigoma & 89.9 & 98.2 & 3.7 & $92.3^{3}$ & 9.2 & 77.5 & 78.4 & 86.1 & 80.6 & 79.3 & 8 & 90.7 & 32.5 & 36.9 & 34.5 & 56.3 \\
\hline Kilimanjaro & 94.4 & 88.9 & 91.9 & 91.4 & 84.7 & 85.7 & 85.2 & 86.1 & 84.4 & 89.9 & 87 & 93.8 & 42.5 & 52.1 & 46.9 & 61.5 \\
\hline Lindi & 100 & * & 93.7 & 97.2 & 79.9 & * & 81.2 & 68.7 & 94.3 & * & 91.4 & 70.5 & 71.1 & * & 63.9 & 52.4 \\
\hline Manyara & 62.5 & 76.3 & 69.5 & 67.7 & 66.8 & 85.9 & 76.4 & 85.1 & 79.4 & 88.5 & 84 & 85.8 & 30.2 & 56.5 & 43.4 & 56.5 \\
\hline Mara & 9.4 & 86.9 & & .4 & .8 & 82.2 & 77.8 & 8 & 88.3 & 88.5 & 88.4 & 96.8 & 23.3 & 48.8 & 31.2 & 46.5 \\
\hline Mbeya & 86.9 & 89.2 & 8 & 97.1 & 83.7 & 89.5 & 86 & 91.9 & 84.8 & 93.4 & 88.2 & 94.7 & 53.9 & 56.4 & 54.9 & 74.6 \\
\hline Morogoro & 81.6 & 85.3 & 5 & 92.6 & 88.9 & 71.2 & 79.9 & 73.4 & 83.2 & 79.4 & 81.2 & 88.1 & 43.3 & 46.7 & 45 & 53.4 \\
\hline Mtwara & 90.1 & * & 93.3 & 100 & 76.7 & * & 78.8 & 93 & 86.5 & * & 89 & 90.2 & 49.7 & 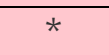 & 52.1 & 76 \\
\hline Mwanza & 64.2 & 72 & 67.4 & 87.3 & 85.2 & 83.6 & 84.5 & 75.1 & 89.1 & 85 & 87.4 & 92.9 & 24.9 & 39 & 30.6 & 38.9 \\
\hline Njombe & 79.5 & * & 80.3 & 87.4 & 83.3 & * & 83.8 & 87.4 & 85.8 & * & 87.4 & 96.4 & 35.7 & * & 40 & 67.1 \\
\hline Pwani & 97.5 & 96.6 & 9 & 92.7 & 88.2 & 80.7 & 84.8 & 84.2 & 85 & 96.7 & 90.3 & 91.2 & 41.8 & 48.6 & 45 & 49.7 \\
\hline Rukwa & * & * & 84.6 & 82.6 & * & * & 86.5 & 81.1 & * & * & 89.6 & 95.3 & 37.2 & * & 47.5 & 65 \\
\hline Ruvuma & 75 & * & 83.4 & 81.1 & 89.4 & * & 91.2 & 81.5 & 89.2 & A & 91.6 & 85.6 & 36.5 & * & 49.2 & 52.5 \\
\hline Shinyanga & 61.3 & * & 66.3 & 67.5 & 86.6 & - & 90.1 & 83.4 & 96.7 & * & 95.9 & 93.9 & 31.3 & 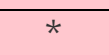 & 38.9 & 43.1 \\
\hline Simiyu & 64.4 & 86 & 72.3 & 73.3 & 85.9 & 67.1 & 79 & 78.8 & 92.4 & 73.7 & 85.6 & 92.3 & 30.1 & 28.3 & 29.5 & 37.2 \\
\hline Singida & 73.1 & 75.9 & 74.3 & 71.2 & 87.1 & 81.8 & 84.9 & 88.1 & 84.6 & 85.4 & 84.9 & 90.5 & 43.2 & 39 & 41.5 & 42.8 \\
\hline Tabora & 68.1 & 76.1 & 71.2 & 74.9 & 75 & 84.4 & 78.6 & 82.2 & 93.4 & 92.1 & 92.9 & 92.4 & 35 & 43.3 & 38.2 & 46.5 \\
\hline Tanga & 70.3 & * & 73.7 & 85.9 & 82.5 & * & 76.1 & 86.8 & 87.9 & * & 88.5 & 90.6 & 39.2 & * & 39.8 & 58 \\
\hline
\end{tabular}




\begin{tabular}{|c|c|c|c|c|c|c|c|c|c|c|c|c|c|c|c|c|}
\hline \multirow{2}{*}{ Region } & \multicolumn{4}{|c|}{$\begin{array}{c}\text { A healthy-looking person can } \\
\text { have the AIDS virus }\end{array}$} & \multicolumn{4}{|c|}{$\begin{array}{l}\text { AIDS cannot be transmitted by } \\
\text { mosquito bites }\end{array}$} & \multicolumn{4}{|c|}{$\begin{array}{l}\text { AIDS cannot be transmitted by } \\
\text { supernatural means }{ }^{b}\end{array}$} & \multicolumn{4}{|c|}{$\begin{array}{c}\text { Percent with a } \\
\text { comprehensive knowledge } \\
\text { about HIV/AIDS }\end{array}$} \\
\hline & $\begin{array}{l}15-17 \\
\text { years }\end{array}$ & $\begin{array}{l}18-19 \\
\text { years }\end{array}$ & $\begin{array}{l}15-19 \\
\text { years }\end{array}$ & $\begin{array}{l}20-24 \\
\text { years }\end{array}$ & $\begin{array}{l}15-17 \\
\text { years }\end{array}$ & $\begin{array}{l}18-19 \\
\text { years }\end{array}$ & $\begin{array}{c}15- \\
19 \\
\text { years }\end{array}$ & $\begin{array}{c}20- \\
24 \\
\text { years }\end{array}$ & $\begin{array}{c}15- \\
17 \\
\text { years }\end{array}$ & $\begin{array}{c}18- \\
19 \\
\text { years }\end{array}$ & $\begin{array}{c}15- \\
19 \\
\text { years }\end{array}$ & $\begin{array}{c}20- \\
24 \\
\text { years }\end{array}$ & $\begin{array}{c}15- \\
17 \\
\text { years }\end{array}$ & $\begin{array}{c}18- \\
19 \\
\text { years }\end{array}$ & $\begin{array}{c}15- \\
19 \\
\text { years }\end{array}$ & $\begin{array}{c}20- \\
24 \\
\text { years }\end{array}$ \\
\hline \multicolumn{17}{|l|}{ Zanzibar } \\
\hline $\begin{array}{l}\text { Kaskazini } \\
\text { Unguja }\end{array}$ & 87.9 & * & 90.9 & 100 & 77.9 & * & 81.4 & 77.3 & 83.1 & * & 83.3 & 83.2 & 34.3 & * & 27 & 29.4 \\
\hline Kusini Unguja & 94 & * & 91.3 & 96 & 87.8 & * & 91.8 & 85.4 & 78 & * & 83.7 & 81.7 & 43.5 & * & 43.5 & 37.5 \\
\hline $\begin{array}{c}\text { Mjini } \\
\text { Magharibi }\end{array}$ & 94 & * & 95.7 & 97.5 & 82.8 & * & 83.6 & 91.1 & 73.6 & * & 82.6 & 97.7 & 13.2 & * & 25.2 & 35.4 \\
\hline $\begin{array}{l}\text { Kaskazini } \\
\text { Pemba }\end{array}$ & 52.7 & 86.3 & 67.5 & 82 & 72 & 74.8 & 73.2 & 76.8 & 75.1 & 78.1 & 76.4 & 77.3 & 20.9 & 22.7 & 21.7 & 29.1 \\
\hline Kusini Pemba & 70.8 & * & 72.3 & 76.2 & 85 & * & 85.4 & 97.4 & 87.8 & * & 88.4 & 93.2 & 30 & * & 33.8 & 43.2 \\
\hline Mainland & 75.2 & 86.1 & 79.6 & 86.3 & 82.8 & 82.4 & 82.6 & 82.7 & 88.4 & 88.3 & 88.3 & 90.6 & 39.1 & 47.5 & 42.4 & 53.7 \\
\hline Zanzibar & 84.3 & 92.8 & 87.6 & 93.6 & 81.9 & 84.6 & 82.9 & 88.4 & 77.7 & 91 & 82.9 & 92.4 & 21.6 & 36.9 & 27.6 & 35 \\
\hline Urban & 87 & 95.7 & 90.8 & 94.1 & 87.4 & 83.8 & 85.8 & 91.5 & 92.3 & 90.7 & 91.6 & 91.5 & 49.9 & 46.4 & 48.4 & 64.5 \\
\hline Rural & 72.3 & 83.2 & 76.5 & 83.4 & 81.4 & 82 & 81.7 & 79.2 & 86.8 & 87.6 & 87.1 & 90.3 & 35.3 & 47.3 & 39.9 & 48.1 \\
\hline National & 75.5 & 86.4 & 79.9 & 86.6 & 82.8 & 82.4 & 82.6 & 82.9 & 88 & 88.4 & 88.1 & 90.6 & 38.5 & 47.1 & 41.9 & 53 \\
\hline
\end{tabular}




\begin{tabular}{|c|c|c|c|c|c|c|c|c|c|c|c|c|}
\hline \multirow[t]{2}{*}{ Region } & \multicolumn{4}{|c|}{ HIV can be transmitted by breastfeeding } & \multicolumn{4}{|c|}{$\begin{array}{l}\text { Risk of MTCT can be reduced by mother } \\
\text { taking special drugs during pregnancy }\end{array}$} & \multicolumn{4}{|c|}{$\begin{array}{l}\text { HIV can be transmitted by breastfeeding, } \\
\text { and risk of MTCT can be reduced by mother } \\
\text { taking special drugs during pregnancy }\end{array}$} \\
\hline & $\begin{array}{l}15-17 \\
\text { years }\end{array}$ & $\begin{array}{l}18-19 \\
\text { years }\end{array}$ & $\begin{array}{l}15-19 \\
\text { years }\end{array}$ & $\begin{array}{l}20-24 \\
\text { years }\end{array}$ & $\begin{array}{l}15-17 \\
\text { years }\end{array}$ & $\begin{array}{l}18-19 \\
\text { years }\end{array}$ & $\begin{array}{l}15-19 \\
\text { years }\end{array}$ & $\begin{array}{l}20-24 \\
\text { years }\end{array}$ & $\begin{array}{l}15-17 \\
\text { years }\end{array}$ & $\begin{array}{l}18-19 \\
\text { years }\end{array}$ & $\begin{array}{l}15-19 \\
\text { years }\end{array}$ & $\begin{array}{l}20-24 \\
\text { years }\end{array}$ \\
\hline \multicolumn{13}{|l|}{ Mainland } \\
\hline Arusha & 84.4 & 81.9 & 83.4 & 79.9 & 89.6 & * & 91.2 & 84 & 74.9 & 77.2 & 75.8 & 66.5 \\
\hline Dodoma & 86.8 & * & 85.9 & 91.3 & 62.4 & * & 63.8 & 68.9 & 54.2 & * & 54.8 & 63.5 \\
\hline Iringa & 76 & 74.4 & 75.4 & 87.7 & 54.7 & * & 63.4 & 82.8 & 47.4 & 53.4 & 49.9 & 73.6 \\
\hline Kagera & 85.2 & 95.8 & 89.2 & 98.4 & 67 & 78.2 & 71.4 & 82.2 & 56.5 & 74.9 & 63.5 & 80.7 \\
\hline Kigoma & 86.5 & * & 88 & 93.7 & 57.6 & * & 62.2 & 81.4 & 50.9 & * & 55.8 & 75.4 \\
\hline Kilimanjaro & 91.6 & * & 94.1 & 87.9 & 57.1 & * & 65 & 87.4 & 53.1 & * & 61.8 & 76.3 \\
\hline Lindi & * & * & 82.4 & 93.2 & * & * & 82.4 & 83.7 & * & * & 67.9 & 79 \\
\hline Manyara & 63.1 & 86.3 & 72.3 & 83.7 & 46.2 & 88.4 & 66.3 & 69 & 30.5 & 75.5 & 48.3 & 58.7 \\
\hline Mbeya & 73.9 & * & 76.6 & 93.5 & 47.7 & * & 56.2 & 84.2 & 37.6 & * & 47.1 & 78.2 \\
\hline Morogoro & 89.5 & 93.1 & 91.3 & 100 & 83.7 & 73.3 & 78.7 & 82.8 & 79.7 & 68.3 & 73.9 & 82.8 \\
\hline Mtwara & 83.2 & * & 89.2 & 100 & 66.3 & * & 76 & 97.4 & 55.2 & * & 67.8 & 97.4 \\
\hline Mwanza & 75.3 & 91.6 & 81.1 & 87.7 & 56.4 & 64.7 & 59.8 & 79.2 & 42.6 & 59.1 & 48.5 & 71.5 \\
\hline Pwani & 100 & * & 98.1 & 98.6 & 79 & * & 85 & 88.4 & 79 & * & 83.2 & 88.4 \\
\hline Rukwa & 56.7 & * & 68.8 & 83.1 & 50 & * & 56.8 & 62.6 & 29.6 & * & 40.3 & 57.1 \\
\hline Ruvuma & 84 & * & 89.4 & 98.3 & 62.2 & * & 67.3 & 82.9 & 52.2 & * & 60.1 & 82.9 \\
\hline Shinyanga & 66.1 & 82.9 & 73.4 & 92.4 & 73.2 & 86 & 79.4 & 90.7 & 48.9 & 73.9 & 59.7 & 84.4 \\
\hline Singida & 72 & * & 75.3 & 75.7 & 72.6 & * & 71.2 & 71.4 & 52.2 & * & 53 & 52.7 \\
\hline Tabora & 56.7 & 64.5 & 59.7 & 90.7 & 82.6 & 93.7 & 86.9 & 91.1 & 49.8 & 60.4 & 53.9 & 84.3 \\
\hline Tanga & 96 & * & 92 & 92.5 & 68.7 & * & 69 & 84.1 & 65.9 & * & 63.8 & 81 \\
\hline
\end{tabular}

127 


\begin{tabular}{|c|c|c|c|c|c|c|c|c|c|c|c|c|}
\hline \multirow[t]{2}{*}{ Region } & \multicolumn{4}{|c|}{ HIV can be transmitted by breastfeeding } & \multicolumn{4}{|c|}{$\begin{array}{l}\text { Risk of MTCT can be reduced by mother } \\
\text { taking special drugs during pregnancy }\end{array}$} & \multicolumn{4}{|c|}{$\begin{array}{l}\text { HIV can be transmitted by breastfeeding, } \\
\text { and risk of MTCT can be reduced by mother } \\
\text { taking special drugs during pregnancy }\end{array}$} \\
\hline & $\begin{array}{l}15-17 \\
\text { years }\end{array}$ & $\begin{array}{l}18-19 \\
\text { years }\end{array}$ & $\begin{array}{l}15-19 \\
\text { years }\end{array}$ & $\begin{array}{l}20-24 \\
\text { years }\end{array}$ & $\begin{array}{l}15-17 \\
\text { years }\end{array}$ & $\begin{array}{l}18-19 \\
\text { years }\end{array}$ & $\begin{array}{l}15-19 \\
\text { years }\end{array}$ & $\begin{array}{l}20-24 \\
\text { years }\end{array}$ & $\begin{array}{l}15-17 \\
\text { years }\end{array}$ & $\begin{array}{l}18-19 \\
\text { years }\end{array}$ & $\begin{array}{l}15-19 \\
\text { years }\end{array}$ & $\begin{array}{l}20-24 \\
\text { years }\end{array}$ \\
\hline \multicolumn{13}{|l|}{ Zanzibar } \\
\hline $\begin{array}{c}\text { Kaskazini } \\
\text { Unguja }\end{array}$ & 84.3 & 68 & 78.1 & 82 & 83.8 & 95 & 87.8 & 82.4 & 70.4 & 64.1 & 68 & 67.3 \\
\hline Kusini Unguja & 91.1 & 91.9 & 91.4 & 94.7 & 90.8 & 94.9 & 92.4 & 87.5 & 82.3 & 87 & 84.2 & 82.7 \\
\hline $\begin{array}{c}\text { Mjini } \\
\text { Magharibi }\end{array}$ & 86.4 & 90 & 87.8 & 95.2 & 90.9 & 95.4 & 92.7 & 95.4 & 80.8 & 85.7 & 82.7 & 90.8 \\
\hline $\begin{array}{c}\text { Kaskazini } \\
\text { Pemba }\end{array}$ & 83.8 & 100 & 89.4 & 88 & 67.7 & 79.5 & 72.2 & 82.9 & 56.7 & 79.5 & 64.6 & 73.3 \\
\hline Kusini Pemba & 87.7 & 87.7 & 87.7 & 87.7 & 63.9 & 73.8 & 67.4 & 86.6 & 56.3 & 63.8 & 58.9 & 76 \\
\hline Mainland & 79.6 & 88 & 82.6 & 91.2 & 67.7 & 78.5 & 71.7 & 84.1 & 54.9 & 69.9 & 60.3 & 77.7 \\
\hline Zanzibar & 86.2 & 88 & 86.8 & 90.6 & 79.5 & 88.2 & 82.9 & 89.3 & 69.2 & 77.1 & 72.2 & 81 \\
\hline Rural & 77.4 & 85.4 & 80.3 & 89.7 & 61.5 & 78.3 & 67.9 & 80.7 & 48.5 & 67.7 & 55.5 & 73.2 \\
\hline National & 79.8 & 88 & 82.8 & 91.1 & 68.1 & 78.9 & 72.1 & 84.2 & 55.4 & 70.1 & 60.7 & 77.8 \\
\hline
\end{tabular}




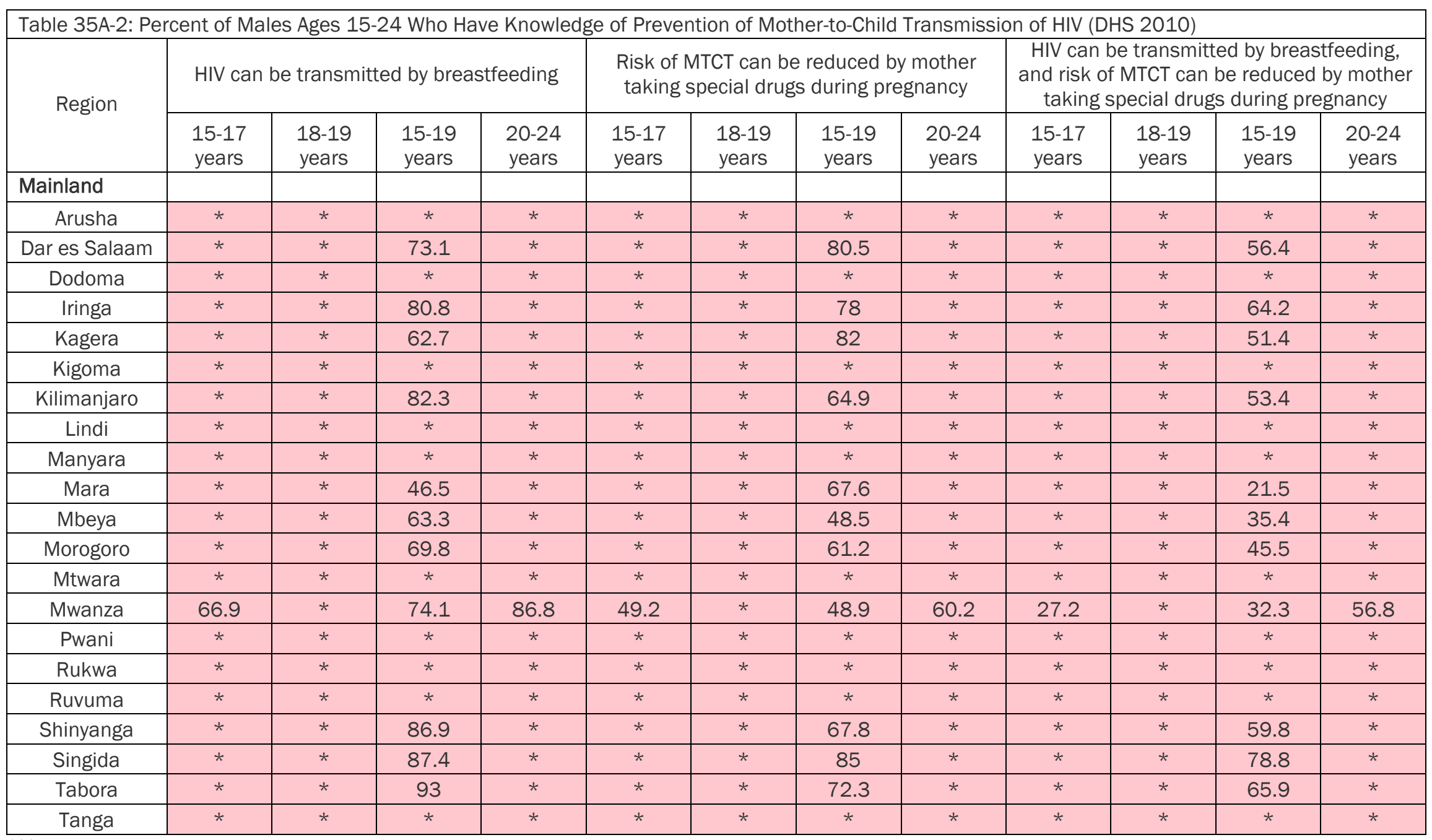


Table 35A-2: Percent of Males Ages 15-24 Who Have Knowledge of Prevention of Mother-to-Child Transmission of HIV (DHS 2010)

\begin{tabular}{|c|c|c|c|c|c|c|c|c|c|c|c|c|}
\hline \multirow[t]{2}{*}{ Region } & \multicolumn{4}{|c|}{ HIV can be transmitted by breastfeeding } & \multicolumn{4}{|c|}{$\begin{array}{l}\text { Risk of MTCT can be reduced by mother } \\
\text { taking special drugs during pregnancy }\end{array}$} & \multicolumn{4}{|c|}{$\begin{array}{l}\text { HIV can be transmitted by breastfeeding, } \\
\text { and risk of MTCT can be reduced by mother } \\
\text { taking special drugs during pregnancy }\end{array}$} \\
\hline & $\begin{array}{l}15-17 \\
\text { years }\end{array}$ & $\begin{array}{l}18-19 \\
\text { years }\end{array}$ & $\begin{array}{l}15-19 \\
\text { years }\end{array}$ & $\begin{array}{l}20-24 \\
\text { years }\end{array}$ & $\begin{array}{l}15-17 \\
\text { years }\end{array}$ & $\begin{array}{l}18-19 \\
\text { years }\end{array}$ & $\begin{array}{l}15-19 \\
\text { years }\end{array}$ & $\begin{array}{l}20-24 \\
\text { years }\end{array}$ & $\begin{array}{l}15-17 \\
\text { years }\end{array}$ & $\begin{array}{l}18-19 \\
\text { years }\end{array}$ & $\begin{array}{l}15-19 \\
\text { years }\end{array}$ & $\begin{array}{l}20-24 \\
\text { years }\end{array}$ \\
\hline \multicolumn{13}{|l|}{ Zanzibar } \\
\hline $\begin{array}{c}\text { Kaskazini } \\
\text { Unguja }\end{array}$ & 71.4 & * & 74.8 & * & 78.2 & * & 82.3 & * & 59.3 & * & 64.1 & * \\
\hline $\begin{array}{c}\text { Mjini } \\
\text { Magharibi }\end{array}$ & * & * & 80.3 & * & * & * & 93 & * & * & * & 76.9 & * \\
\hline $\begin{array}{c}\text { Kaskazini } \\
\text { Pemba }\end{array}$ & * & * & 80.6 & * & * & * & 60.4 & * & * & * & 48.7 & * \\
\hline Kusini Pemba & * & * & 82.3 & 100 & * & * & 67 & 84.6 & * & * & 57.5 & 84.6 \\
\hline Mainland & 72.6 & 84.3 & 77 & 85.1 & 61.3 & 74.5 & 66.6 & 69.6 & 43.6 & 62.7 & 50.8 & 60.6 \\
\hline Zanzibar & 75.4 & 79.2 & 77 & 92.2 & 75.4 & 81.8 & 78.1 & 86.3 & 60 & 65 & 62 & 79.8 \\
\hline Urban & 77.5 & 85.4 & 81 & 90.2 & 78.9 & 87.7 & 82.9 & 81.8 & 58.9 & 73.3 & 65.2 & 73.8 \\
\hline National & 72.7 & 84.1 & 77 & 85.4 & 61.8 & 74.8 & 67 & 70.1 & 44.1 & 62.7 & 51.2 & 61.2 \\
\hline
\end{tabular}




\begin{tabular}{|c|c|c|c|c|c|c|c|c|c|c|c|c|}
\hline \multirow[t]{2}{*}{ Region } & \multicolumn{4}{|c|}{ HIV can be transmitted by breastfeeding } & \multicolumn{4}{|c|}{$\begin{array}{l}\text { Risk of MTCT can be reduced by mother taking } \\
\text { special drugs during pregnancy }\end{array}$} & \multicolumn{4}{|c|}{$\begin{array}{c}\text { HIV can be transmitted by breastfeeding, and risk of } \\
\text { MTCT can be reduced by mother taking special } \\
\text { drugs during pregnancy }\end{array}$} \\
\hline & $\begin{array}{l}15-17 \\
\text { years }\end{array}$ & $\begin{array}{l}18-19 \\
\text { years }\end{array}$ & $\begin{array}{l}15-19 \\
\text { years }\end{array}$ & $\begin{array}{l}20-24 \\
\text { years }\end{array}$ & $\begin{array}{l}15-17 \\
\text { years }\end{array}$ & $\begin{array}{l}18-19 \\
\text { years }\end{array}$ & $\begin{array}{l}15-19 \\
\text { years }\end{array}$ & $\begin{array}{l}20-24 \\
\text { years }\end{array}$ & $\begin{array}{l}15-17 \\
\text { years }\end{array}$ & $\begin{array}{l}18-19 \\
\text { years }\end{array}$ & $\begin{array}{l}15-19 \\
\text { years }\end{array}$ & $\begin{array}{l}20-24 \\
\text { years }\end{array}$ \\
\hline \multicolumn{13}{|l|}{ Mainland } \\
\hline Arusha & 93.1 & * & 92 & 81.4 & 63 & * & 60.3 & 59.9 & 59.5 & * & 56 & 54 \\
\hline Dar es Salaam & 73.2 & 90.2 & 80.7 & 94.4 & 69.3 & 72.7 & 70.9 & 91 & 51.2 & 65 & 57.2 & 86 \\
\hline Dodoma & 74.9 & * & 76.3 & 71.2 & * & * & 59.8 & 67.3 & * & * & 42.6 & 47.7 \\
\hline Geita & 66.4 & 75.8 & 69.4 & 88.6 & 63.6 & 66 & 64.4 & 76 & 43 & 47.5 & 44.5 & 68.7 \\
\hline Iringa & 96 & 85.1 & 89.7 & 95.5 & 91.7 & 83.8 & 87.2 & 94.5 & 88.6 & 69.9 & 77.8 & 90 \\
\hline Kagera & 78.5 & 100 & 86.4 & 96.4 & 74.3 & 51.9 & 65.3 & 83.6 & 59.9 & 51.9 & 57 & 82 \\
\hline Katavi & 64.3 & 70 & 66.7 & 72.6 & 42.8 & 66.1 & 54.5 & 49.4 & 28.5 & 43.8 & 35 & 39.1 \\
\hline Kigoma & 86.4 & 80.4 & 83.9 & 96.4 & 66.3 & 72.7 & 69.1 & 90.2 & 60.5 & 58.2 & 59.5 & 87.7 \\
\hline Kilimanjaro & 79.3 & 86.4 & 82.2 & 86.4 & 48.4 & 54.6 & 51 & 65 & 40.9 & 48.9 & 44.1 & 57.5 \\
\hline Lindi & 89.8 & * & 91.3 & 97.2 & 72.8 & * & 78.2 & 86.1 & 65.4 & * & 72.6 & 83.7 \\
\hline Manyara & 72.7 & 84.7 & 76.4 & 92.3 & 41.7 & * & 49.3 & 63.6 & 26.5 & 55.3 & 35.4 & 59.8 \\
\hline Mara & 69 & 65.4 & 67.5 & 85.5 & 55.6 & 64.5 & 59.3 & 75.6 & 39.9 & 46.6 & 42.7 & 68.9 \\
\hline Mbeya & 74.2 & 73.7 & 74 & 89.3 & 66.5 & 68.3 & 67.3 & 82.2 & 51 & 51.8 & 51.3 & 74.2 \\
\hline Morogoro & 81.8 & 80.5 & 81.1 & 81.8 & * & 67.5 & 76.6 & 75.4 & 73.5 & 56.4 & 64.1 & 63.2 \\
\hline Mtwara & 91.1 & * & 92.6 & 96.8 & 75.9 & * & 83.2 & 90.9 & 69.1 & * & 78.4 & 89.9 \\
\hline Mwanza & 80.2 & 82.2 & 81 & 87.9 & 71.6 & 72.9 & 72.1 & 79.5 & 57.1 & 62.3 & 59 & 73 \\
\hline Njombe & 75.8 & * & 69 & 88.7 & 80 & * & 76 & 98.1 & 61.3 & * & 54.3 & 87.2 \\
\hline Pwani & 88.1 & * & 92.1 & 86.3 & 73.9 & * & 76.7 & 88 & 65.1 & * & 70.7 & 76.3 \\
\hline Rukwa & 58.1 & * & 69.3 & 79.7 & 51.1 & * & 66 & 65.4 & 33.3 & * & 51.5 & 54.5 \\
\hline Ruvuma & 93 & 82.3 & 88.7 & 90.9 & 74.9 & 91.8 & 81.1 & 71.3 & 68.4 & 75.4 & 71.2 & 67.2 \\
\hline Shinyanga & 56.2 & 85.8 & 68.1 & 86.4 & 52.6 & 69.9 & 60.5 & 74.4 & 31.7 & 58.7 & 42.5 & 63.8 \\
\hline Simiyu & 49.9 & 71.8 & 59 & 81 & 45 & 44.9 & 44.9 & 67.8 & 19.2 & 33 & 25 & 57.5 \\
\hline Singida & 64.7 & 81.1 & 71.6 & 77.6 & 69 & 65.4 & 67.3 & 70 & 43.5 & 54.1 & 47.9 & 54.4 \\
\hline Tabora & 57.1 & 92.9 & 70.3 & 89.5 & 62.5 & 73.9 & 67.5 & 85.3 & 36.9 & 67.5 & 48.2 & 76.1 \\
\hline Tanga & 72 & 68.8 & 70.6 & 70.5 & 48.9 & * & 52.1 & 70.3 & 32.8 & 40.8 & 36.2 & 50.2 \\
\hline
\end{tabular}


Table 35B-1: Percent of Females Ages 15-24 Who Have Knowledge of Prevention of Mother-to-Child Transmission of HIV (THMIS 2011-2012)

\begin{tabular}{|c|c|c|c|c|c|c|c|c|c|c|c|c|}
\hline \multirow[t]{2}{*}{ Region } & \multicolumn{4}{|c|}{ HIV can be transmitted by breastfeeding } & \multicolumn{4}{|c|}{$\begin{array}{c}\text { Risk of MTCT can be reduced by mother taking } \\
\text { special drugs during pregnancy }\end{array}$} & \multicolumn{4}{|c|}{$\begin{array}{c}\text { HIV can be transmitted by breastfeeding, and risk of } \\
\text { MTCT can be reduced by mother taking special } \\
\text { drugs during pregnancy }\end{array}$} \\
\hline & $\begin{array}{l}15-17 \\
\text { years }\end{array}$ & $\begin{array}{l}18-19 \\
\text { years }\end{array}$ & $\begin{array}{l}15-19 \\
\text { years }\end{array}$ & $\begin{array}{l}20-24 \\
\text { years }\end{array}$ & $\begin{array}{l}15-17 \\
\text { years }\end{array}$ & $\begin{array}{l}18-19 \\
\text { years }\end{array}$ & $\begin{array}{l}15-19 \\
\text { years }\end{array}$ & $\begin{array}{l}20-24 \\
\text { years }\end{array}$ & $\begin{array}{l}15-17 \\
\text { years }\end{array}$ & $\begin{array}{l}18-19 \\
\text { years }\end{array}$ & $\begin{array}{l}15-19 \\
\text { years }\end{array}$ & $\begin{array}{l}20-24 \\
\text { years }\end{array}$ \\
\hline \multicolumn{13}{|l|}{ Zanzibar } \\
\hline Kaskazini Unguja & 86.9 & 84 & 85.9 & 85.7 & 55.1 & * & 62.5 & 79.1 & 47.9 & 61.4 & 52.5 & 68.9 \\
\hline Kusini Unguja & 84.2 & * & 86.4 & 95.4 & 78.2 & * & 77.1 & 84.5 & 66.1 & * & 66.1 & 82.2 \\
\hline Mjini Magharibi & 92 & 94.6 & 93.1 & 95.9 & 73.5 & 81.8 & 77.2 & 93.3 & 67.6 & 77.1 & 71.7 & 89.4 \\
\hline Kaskazini Pemba & 88.4 & 93.5 & 90.3 & 88.9 & 51.9 & 61.2 & 55.5 & 78.1 & 46.8 & 57.3 & 50.8 & 70 \\
\hline Kusini Pemba & 94.9 & 84.2 & 90.8 & 94.8 & 46.4 & * & 54 & 69.8 & 45.1 & 55.4 & 49.1 & 65.9 \\
\hline Mainland & 73.7 & 81.5 & 76.9 & 87 & 64.3 & 68.1 & 65.9 & 78.1 & 47.9 & 56.2 & 51.3 & 69.5 \\
\hline Zanzibar & 90.8 & 92.3 & 91.4 & 93.8 & 65.5 & 77 & 70.3 & 86.2 & 59.7 & 70.4 & 64.1 & 81.1 \\
\hline Urban & 82.1 & 87.7 & 84.2 & 92.8 & 76.1 & 79.5 & 77.5 & 88.4 & 61.6 & 71.3 & 65.3 & 83.5 \\
\hline Rural & 71.3 & 79.9 & 74.9 & 85.1 & 59.2 & 64.4 & 61.5 & 74.5 & 43.1 & 51.8 & 46.7 & 64.9 \\
\hline National & 74.4 & 81.9 & 77.4 & 87.2 & 64.3 & 68.5 & 66.1 & 78.5 & 48.4 & 56.8 & 51.8 & 70 \\
\hline
\end{tabular}




\begin{tabular}{|c|c|c|c|c|c|c|c|c|c|c|c|c|}
\hline Region & \multicolumn{4}{|c|}{ HIV can be transmitted by breastfeeding } & \multicolumn{4}{|c|}{$\begin{array}{l}\text { Risk of MTCT can be reduced by mother } \\
\text { taking special drugs during pregnancy }\end{array}$} & \multicolumn{4}{|c|}{$\begin{array}{l}\text { HIV can be transmitted by breastfeeding, } \\
\text { and risk of MTCT can be reduced by mother } \\
\text { taking special drugs during pregnancy }\end{array}$} \\
\hline \multicolumn{13}{|l|}{ Mainland } \\
\hline Arusha & 82.1 & * & 82.6 & 96.5 & 55.6 & * & 56.1 & 66.3 & 47.2 & * & 49.4 & 62.8 \\
\hline Dodoma & 43.6 & * & 57.1 & 55.8 & 53 & * & 59.3 & 68.4 & 25.6 & * & 35.7 & 34.6 \\
\hline Geita & 60.3 & 79.6 & 67.4 & 82 & 42 & 54.6 & 47.2 & 52.6 & 25.5 & 43.9 & 32.2 & 46.5 \\
\hline Iringa & 82.5 & 77.1 & 80.3 & 91.8 & 85.4 & 86.9 & 86 & 74.6 & 69.8 & 65.2 & 67.9 & 67.4 \\
\hline Kagera & 63.4 & * & 66.9 & 76.6 & 56.8 & * & 54.9 & 69.4 & 35.2 & * & 34.3 & 51.3 \\
\hline Katavi & 73.6 & * & 75.8 & 75.2 & 55.7 & * & 62.7 & 84.7 & 44.9 & * & 47.7 & 63.6 \\
\hline Kigoma & 52.2 & 71.8 & 61.2 & 84.8 & 60.9 & 73.8 & 67.7 & 56.3 & 33.6 & 60.4 & 45.9 & 46.8 \\
\hline Kilimanjaro & 70.9 & 64.7 & 68 & 69.6 & 74.3 & 84.3 & 78.9 & 63.1 & 53.6 & 56.2 & 54.8 & 42.5 \\
\hline Manyara & 70.2 & 73 & 71.6 & 62.6 & 51.5 & 61.6 & 56.7 & 65.5 & 31.5 & 50.3 & 40.9 & 40.6 \\
\hline Mara & 61.6 & 63.3 & 62.1 & 75.9 & 67.4 & 76.2 & 70.5 & 75.3 & 40.3 & 45.7 & 42 & 60.6 \\
\hline Mbeya & 63.7 & 69.2 & 65.8 & 80.5 & 86.7 & 68.8 & 80 & 77.2 & 55.4 & 49 & 52.9 & 65.2 \\
\hline Morogoro & 83.6 & 65.2 & 74.3 & 80.9 & 66.1 & 59.1 & 62.8 & 68.7 & 58 & 38.4 & 48.2 & 56.7 \\
\hline Mtwara & 86.3 & * & 83.7 & 81.9 & 62.2 & * & 73.2 & 77.1 & 54.8 & * & 60.7 & 64.7 \\
\hline Mwanza & 72.3 & 72.5 & 72.4 & 75.3 & 60.7 & 61.2 & 60.9 & 64.5 & 41.7 & 42 & 41.8 & 53 \\
\hline Njombe & 78.5 & * & 78.8 & 81.9 & 52.2 & * & 57.1 & 78.2 & 45 & * & 48.1 & 68 \\
\hline Pwani & 75.7 & 83.9 & 79.5 & 93.9 & 67.8 & 76.8 & 72 & 74.9 & 48.1 & 68.2 & 57.3 & 71.6 \\
\hline Rukwa & * & * & 69.4 & 82.3 & * & $\star$ & 71.6 & 78.3 & * & * & 54.1 & 64.7 \\
\hline Ruvuma & 88 & * & 84.7 & 94.1 & 75.6 & * & 74.9 & 78.6 & 66.9 & * & 62.4 & 73.5 \\
\hline Shinyanga & 63 & * & 67.9 & 81.2 & 51.2 & * & 59.6 & 71.9 & 36.1 & * & 41.7 & 58.3 \\
\hline Simiyu & 58.2 & 72.6 & 63.4 & 64.2 & 66.1 & 53.9 & 61.2 & 56.9 & 38.4 & 45.9 & 41.1 & 34.3 \\
\hline Singida & 47.7 & 64 & 54.5 & 63.5 & 50.4 & 54.6 & 52.4 & 60.6 & 20.7 & 36.1 & 27.2 & 41.3 \\
\hline Tabora & 75 & 84.5 & 78.6 & 81 & 56.2 & 68.4 & 60.9 & 77.4 & 42.5 & 57.2 & 47.9 & 63.9 \\
\hline Tanga & 66.6 & * & 68.2 & 85.7 & 68.1 & * & 61.2 & 67.7 & 44.2 & * & 42.3 & 59.3 \\
\hline
\end{tabular}




\begin{tabular}{|c|c|c|c|c|c|c|c|c|c|c|c|c|}
\hline Region & \multicolumn{4}{|c|}{ HIV can be transmitted by breastfeeding } & \multicolumn{4}{|c|}{$\begin{array}{l}\text { Risk of MTCT can be reduced by mother } \\
\text { taking special drugs during pregnancy }\end{array}$} & \multicolumn{4}{|c|}{$\begin{array}{l}\text { HIV can be transmitted by breastfeeding, } \\
\text { and risk of MTCT can be reduced by mother } \\
\text { taking special drugs during pregnancy }\end{array}$} \\
\hline \multicolumn{13}{|l|}{ Zanzibar } \\
\hline $\begin{array}{l}\text { Kaskazini } \\
\text { Unguja }\end{array}$ & 73 & * & 76.4 & 80.8 & 68.6 & * & 57.4 & 67.3 & 53.2 & * & 46.3 & 53 \\
\hline Kusini Unguja & 87.9 & * & 87.6 & 80 & 71.5 & * & 69.9 & 75 & 62.9 & * & 61.7 & 61 \\
\hline $\begin{array}{c}\text { Mjini } \\
\text { Magharibi }\end{array}$ & 81.2 & * & 83.1 & 90.6 & 67 & * & 71.1 & 78.3 & 56.4 & * & 62.4 & 72.8 \\
\hline $\begin{array}{l}\text { Kaskazini } \\
\text { Pemba }\end{array}$ & 82 & 88.7 & 85 & 88.9 & 45 & 48.9 & 46.7 & 48 & 35.9 & 44.8 & 39.8 & 42.5 \\
\hline Kusini Pemba & 87 & * & 87.9 & 90.3 & 60.2 & * & 59.1 & 74.5 & 56.2 & * & 55.5 & 69.7 \\
\hline Mainland & 68.9 & 73.9 & 70.9 & 79.3 & 63.5 & 65.5 & 64.3 & 69.2 & 43.8 & 49 & 45.9 & 55.9 \\
\hline Zanzibar & 82.1 & 86.3 & 83.8 & 88.8 & 63.6 & 65.9 & 64.5 & 73.1 & 54.2 & 61 & 56.8 & 66.3 \\
\hline Rural & 67 & 74.6 & 70 & 76 & 60.2 & 64.8 & 62.1 & 67.9 & 40.5 & 48.8 & 43.7 & 52.8 \\
\hline National & 69.4 & 74.3 & 71.4 & 79.6 & 63.5 & 65.6 & 64.3 & 69.4 & 44.2 & 49.5 & 46.3 & 56.3 \\
\hline
\end{tabular}




\begin{tabular}{|c|c|c|c|c|c|c|c|c|c|c|c|c|c|c|c|c|c|c|c|c|}
\hline \multirow[t]{2}{*}{ Region } & \multicolumn{4}{|c|}{$\begin{array}{l}\text { Are willing to care for a family } \\
\text { member with the AIDS virus in the } \\
\text { respondent's home }\end{array}$} & \multicolumn{4}{|c|}{$\begin{array}{c}\text { Would buy fresh vegetables from } \\
\text { shopkeeper who has the AIDS } \\
\text { virus }\end{array}$} & \multicolumn{4}{|c|}{$\begin{array}{l}\text { Say that a female teacher with } \\
\text { the AIDS virus who is not sick } \\
\text { should be allowed to continue } \\
\text { teaching }\end{array}$} & \multicolumn{4}{|c|}{$\begin{array}{l}\text { Would not want to keep secret } \\
\text { that a family member got } \\
\text { infected with the AIDS virus }\end{array}$} & \multicolumn{4}{|c|}{$\begin{array}{l}\text { Percent expressing } \\
\text { acceptance on all four } \\
\text { indicators }\end{array}$} \\
\hline & $\begin{array}{l}15-17 \\
\text { years }\end{array}$ & $\begin{array}{l}18-19 \\
\text { years }\end{array}$ & $\begin{array}{l}15-19 \\
\text { years }\end{array}$ & $\begin{array}{l}20-24 \\
\text { years }\end{array}$ & $\begin{array}{l}15-17 \\
\text { years }\end{array}$ & $\begin{array}{l}18-19 \\
\text { years }\end{array}$ & $\begin{array}{l}15-19 \\
\text { years }\end{array}$ & $\begin{array}{l}20-24 \\
\text { years }\end{array}$ & $\begin{array}{l}15-17 \\
\text { years }\end{array}$ & $\begin{array}{l}18-19 \\
\text { years }\end{array}$ & $\begin{array}{l}15-19 \\
\text { years }\end{array}$ & $\begin{array}{c}20-24 \\
\text { years }\end{array}$ & $\begin{array}{l}15-17 \\
\text { years }\end{array}$ & $\begin{array}{l}18-19 \\
\text { years }\end{array}$ & $\begin{array}{l}15-19 \\
\text { years }\end{array}$ & $\begin{array}{l}20-24 \\
\text { years }\end{array}$ & $\begin{array}{l}15- \\
17 \\
\text { years }\end{array}$ & $\begin{array}{c}18- \\
19 \\
\text { years }\end{array}$ & $\begin{array}{c}15- \\
19 \\
\text { years }\end{array}$ & $\begin{array}{c}20- \\
24 \\
\text { years } \\
\end{array}$ \\
\hline \multicolumn{21}{|l|}{ Mainland } \\
\hline Arusha & 88 & 86.7 & 87.5 & 84.3 & 68.6 & 83.4 & 74 & 62.6 & 86.7 & 86.7 & 86.7 & 68.9 & 37.9 & 51.8 & 43 & 44.8 & 27.9 & 43.9 & 33.8 & 32.6 \\
\hline Dar es & مـ & 966 & 980 & 96 & 858 & 908 & 871 & 855 & 966 & 973 & 968 & 963 & 33 & 121 & 350 & 116 & 293 & 320 & 301 & 358 \\
\hline Dodoma & 92.9 & * & 90.4 & 91.2 & 60.6 & * & 60.6 & 51.1 & 81 & * & 81.9 & 76 & 28.1 & * & 34.7 & 45.4 & 16.4 & 18.9 & 17 & 15.9 \\
\hline Iringa & 97.1 & 94.9 & 96.2 & 94.4 & 71.3 & 75.2 & 72.9 & 84.4 & 92.3 & 97.1 & 94.3 & 91.8 & 27.3 & 45.2 & 34.8 & 43.5 & 22.2 & 37.7 & 28.6 & 35 \\
\hline Kagera & 87.4 & 94.4 & 90.1 & 93 & 58.8 & 67.8 & 62.2 & 75.6 & 76.2 & 85.1 & 79.6 & 82.9 & 45.1 & 47.8 & 46.2 & 38.4 & 19.2 & 32.5 & 24.2 & 25 \\
\hline Kigoma & 76.3 & * & 80.5 & 97.3 & 65.2 & * & 66.9 & 64.8 & 80.9 & * & 83.7 & 84.6 & 47.8 & * & 46.2 & 48.7 & 30.5 & 34.2 & 31.5 & 32.7 \\
\hline Kilimanjaro & 86 & * & 88 & 96.6 & 86 & 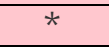 & 88 & 89.2 & 92.6 & * & 93.9 & 94.9 & 56.9 & * & 58.8 & 43.2 & 45.3 & 59.1 & 49.4 & 37.5 \\
\hline Lindi & * & * & 100 & 98.4 & * & * & 80.4 & 86.7 & * & * & 84.6 & 91.6 & * & * & 19.3 & 11.3 & 16.8 & 16.8 & 16.8 & 7.5 \\
\hline Manyara & 72.4 & 92.9 & 80.5 & 78 & 46.7 & 60.1 & 52 & 50.3 & 68.4 & 83.1 & 74.2 & 62.6 & 29.3 & 27.7 & 28.7 & 62.3 & 13.1 & 16.8 & 14.6 & 25 \\
\hline Mara & 89.3 & 85.7 & 88 & 93 & 66.9 & 57.7 & 63.7 & 74.7 & 89.5 & 71.3 & 83.2 & 87.3 & 32.5 & 36.2 & 33.8 & 35 & 23.6 & 17.2 & 21.4 & 22.6 \\
\hline Mbeya & 81.9 & * & 81.2 & 98.8 & 61.6 & * & 70 & 90.7 & 79.3 & * & 80.4 & 93 & 23.7 & $\star$ & 29.5 & 41.1 & 15.1 & 35.9 & 21.5 & 35.3 \\
\hline Morogoro & 91.6 & 89.4 & 90.5 & 96.6 & 90.2 & 74.2 & 82.2 & 80.5 & 88.7 & 88.8 & 88.8 & 94.5 & 54.3 & 49.9 & 52.1 & 60.7 & 50.2 & 37.6 & 44 & 50.8 \\
\hline Mtwara & 94.6 & * & 96.6 & 100 & 86.7 & * & 87.2 & 81.8 & 94.9 & * & 93.7 & 97.3 & 23.2 & * & 26.7 & 18.6 & 18.1 & 29.7 & 22.2 & 12.5 \\
\hline Pwani & 78.2 & * & 87.3 & 98.8 & 69.8 & * & 73.1 & 71.1 & 84.9 & * & 83.3 & 91.6 & 54.4 & * & 49.1 & 57.1 & 24.1 & 26.7 & 25.2 & 45.8 \\
\hline Rukwa & 82.5 & * & 82.3 & 86.1 & 59.7 & t & 63.6 & 53.4 & 72.4 & 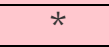 & 79.9 & 84.7 & 27.2 & $\star$ & 34.2 & 41.6 & 17.1 & 32.1 & 22.4 & 28.7 \\
\hline Ruvuma & 97.1 & * & 94.5 & 91.8 & 64.4 & - & 64 & 71.2 & 97.1 & - & 98.1 & 91.6 & 44.2 & * & 41.9 & 47.9 & 30.6 & 31.8 & 31 & 30.6 \\
\hline Shinyanga & 88.2 & 92 & 89.8 & 94.7 & 71.9 & 74.3 & 72.9 & 72.2 & 70.7 & 79 & 74.3 & 73.8 & 65 & 58.7 & 62.3 & 54.7 & 46.8 & 46.3 & 46.6 & 38.3 \\
\hline Singida & 81.8 & * & 83.5 & 94.4 & 65.6 & * & 60.9 & 71.1 & 76 & * & 74.4 & 81.4 & 50.1 & * & 53.4 & 49.4 & 29.2 & 36 & 31.1 & 31.1 \\
\hline Tabora & 88.9 & 83.5 & 86.8 & 88.1 & 57.4 & 51 & 54.9 & 59 & 77.5 & 84.1 & 80 & 78.5 & 42.7 & 53.8 & 47 & 45.3 & 28 & 32 & 29.5 & 33.1 \\
\hline Tanga & 80.7 & $*$ & 83.4 & 92.4 & 75.2 & * & 75.5 & 67.2 & 94.2 & * & 93.2 & 89.3 & 32.2 & * & 33.5 & 41.5 & 26.2 & 31.4 & 27.8 & 25.9 \\
\hline
\end{tabular}




\begin{tabular}{|c|c|c|c|c|c|c|c|c|c|c|c|c|c|c|c|c|c|c|c|c|}
\hline \multirow[t]{2}{*}{ Region } & \multicolumn{4}{|c|}{$\begin{array}{l}\text { Are willing to care for a family } \\
\text { member with the AIDS virus in the } \\
\text { respondent's home }\end{array}$} & \multicolumn{4}{|c|}{$\begin{array}{c}\text { Would buy fresh vegetables from } \\
\text { shopkeeper who has the AIDS } \\
\text { virus }\end{array}$} & \multicolumn{4}{|c|}{$\begin{array}{l}\text { Say that a female teacher with } \\
\text { the AIDS virus who is not sick } \\
\text { should be allowed to continue } \\
\text { teaching }\end{array}$} & \multicolumn{4}{|c|}{$\begin{array}{c}\text { Would not want to keep secret } \\
\text { that a family member got } \\
\text { infected with the AIDS virus }\end{array}$} & \multicolumn{4}{|c|}{$\begin{array}{l}\text { Percent expressing } \\
\text { acceptance on all four } \\
\text { indicators }\end{array}$} \\
\hline & $\begin{array}{l}15-17 \\
\text { years }\end{array}$ & $\begin{array}{l}18-19 \\
\text { years }\end{array}$ & $\begin{array}{l}15-19 \\
\text { years }\end{array}$ & $\begin{array}{l}20-24 \\
\text { years }\end{array}$ & $\begin{array}{l}15-17 \\
\text { years }\end{array}$ & $\begin{array}{l}18-19 \\
\text { years }\end{array}$ & $\begin{array}{l}15-19 \\
\text { years }\end{array}$ & $\begin{array}{l}20-24 \\
\text { years }\end{array}$ & $\begin{array}{l}15-17 \\
\text { years }\end{array}$ & $\begin{array}{l}18-19 \\
\text { years }\end{array}$ & $\begin{array}{l}15-19 \\
\text { years }\end{array}$ & $\begin{array}{l}20-24 \\
\text { years }\end{array}$ & $\begin{array}{l}15-17 \\
\text { years }\end{array}$ & $\begin{array}{l}18-19 \\
\text { years }\end{array}$ & $\begin{array}{l}15-19 \\
\text { years }\end{array}$ & $\begin{array}{l}20-24 \\
\text { years }\end{array}$ & $\begin{array}{c}15- \\
17 \\
\text { years }\end{array}$ & $\begin{array}{c}18- \\
19 \\
\text { years }\end{array}$ & $\begin{array}{c}15- \\
19 \\
\text { years }\end{array}$ & $\begin{array}{c}20- \\
24 \\
\text { years }\end{array}$ \\
\hline Zanzibar & & & & & & & & & & & & & & & & & & & & \\
\hline $\begin{array}{c}\text { Kaskazini } \\
\text { Unguja }\end{array}$ & 86.6 & 86.2 & 86.4 & 92 & 59.8 & 70.5 & 63.9 & 63.5 & 92.6 & 97 & 94.3 & 88.4 & 55.8 & 54.3 & 55.2 & 49.3 & 29.5 & 41.6 & 34.1 & 32.4 \\
\hline $\begin{array}{l}\text { Kusini } \\
\text { Unguja }\end{array}$ & 92.9 & 94 & 93.4 & 96 & 81.1 & 84 & 82.3 & 80.8 & 91.6 & 100 & 94.9 & 94.6 & 47.2 & 62 & 53.1 & 65.6 & 36.9 & 45 & 40.1 & 51.8 \\
\hline $\begin{array}{c}\text { Mjini } \\
\text { Magharibi }\end{array}$ & 93.1 & 97.6 & 94.9 & 99 & 82.5 & 86.9 & 84.2 & 89.1 & 97.9 & 95.5 & 96.9 & 97.3 & 54.7 & 46.9 & 51.7 & 58.8 & 42.9 & 44.8 & 43.7 & 53.7 \\
\hline $\begin{array}{c}\text { Kaskazini } \\
\text { Pemba }\end{array}$ & 83.6 & 95.2 & 87.6 & 84.5 & 48.1 & 53.5 & 49.9 & 61.8 & 82.3 & 95.9 & 87 & 88.4 & 49.5 & 53.9 & 51 & 60.6 & 25.4 & 33.6 & 28.2 & 32.1 \\
\hline $\begin{array}{l}\text { Kusini } \\
\text { Pemba }\end{array}$ & 89.5 & 89.3 & 89.4 & 92.8 & 52.4 & 62.4 & 55.8 & 65.3 & 92.1 & 86.2 & 90.1 & 94.1 & 45.9 & 54.1 & 48.7 & 48.4 & 27 & 33.5 & 29.3 & 30.2 \\
\hline Mainland & 88 & 90.9 & 89 & 94 & 69.3 & 72.4 & 70.4 & 73.1 & 83.4 & 86.7 & 84.5 & 85.3 & 39.2 & 46 & 42.4 & 44.4 & 26.8 & 33.4 & 29.2 & 31.4 \\
\hline Zanzibar & 89.3 & 93.4 & 90.9 & 94.2 & 65.4 & 73.3 & 68.3 & 75.8 & 92.1 & 94.5 & 93 & 93.7 & 51.4 & 52.2 & 41.9 & 56.4 & 33.4 & 40.2 & 35.9 & 42.7 \\
\hline Urban & 96.2 & 96.3 & 96.2 & 97.2 & 81.8 & 85.5 & 83.1 & 83 & 95.2 & 93.6 & 94.6 & 93.2 & 40 & 46.7 & 42.4 & 47.5 & 34.6 & 40.9 & 36.8 & 40.4 \\
\hline Rural & 84.6 & 88.8 & 86.1 & 92.5 & 63.8 & 67 & 64.9 & 68.3 & 78.7 & 84.2 & 80.7 & 81.8 & 39.5 & 46.1 & 41.9 & 43.4 & 23.9 & 30.7 & 26.3 & 27.4 \\
\hline National & 88 & 91 & 89.1 & 94.1 & 69.2 & 72.4 & 70.3 & 73.2 & 83.7 & 87 & 84.8 & 85.6 & 39.6 & 46.3 & 42 & 44.8 & 27.1 & 33.7 & 29.4 & 31.7 \\
\hline
\end{tabular}




\begin{tabular}{|c|c|c|c|c|c|c|c|c|c|c|c|c|c|c|c|c|c|c|c|c|}
\hline \multirow{2}{*}{ Region } & \multicolumn{4}{|c|}{$\begin{array}{l}\text { Are willing to care for a family } \\
\text { member with the AIDS virus in } \\
\text { the respondent's home }\end{array}$} & \multicolumn{4}{|c|}{$\begin{array}{c}\text { Would buy fresh vegetables from } \\
\text { shopkeeper who has the AIDS } \\
\text { virus }\end{array}$} & \multicolumn{4}{|c|}{$\begin{array}{l}\text { Say that a female teacher with } \\
\text { the AIDS virus who is not sick } \\
\text { should be allowed to continue } \\
\text { teaching }\end{array}$} & \multicolumn{4}{|c|}{$\begin{array}{l}\text { Would not want to keep secret } \\
\text { that a family member got } \\
\text { infected with the AIDS virus }\end{array}$} & \multicolumn{4}{|c|}{$\begin{array}{l}\text { Percent expressing } \\
\text { acceptance on all four } \\
\text { indicators }\end{array}$} \\
\hline & $\begin{array}{l}15-17 \\
\text { years }\end{array}$ & & $\begin{array}{l}15-19 \\
\text { years }\end{array}$ & $\begin{array}{l}20-24 \\
\text { years }\end{array}$ & $\begin{array}{l}15-17 \\
\text { years }\end{array}$ & $\begin{array}{l}18-19 \\
\text { years }\end{array}$ & $\begin{array}{l}15-19 \\
\text { years }\end{array}$ & $\begin{array}{l}20-24 \\
\text { years }\end{array}$ & $\begin{array}{l}15-17 \\
\text { years }\end{array}$ & $\begin{array}{l}18-19 \\
\text { years }\end{array}$ & $\begin{array}{l}15-19 \\
\text { years }\end{array}$ & $\begin{array}{l}20-24 \\
\text { years }\end{array}$ & & & $\begin{array}{c}15- \\
19 \\
\text { years }\end{array}$ & $\begin{array}{c}20- \\
24 \\
\text { years }\end{array}$ & $\begin{array}{c}15- \\
17 \\
\text { years }\end{array}$ & $\begin{array}{c}18- \\
19 \\
\text { years }\end{array}$ & $\begin{array}{c}15- \\
19 \\
\text { years }\end{array}$ & $\begin{array}{c}20- \\
24 \\
\text { years }\end{array}$ \\
\hline \multicolumn{21}{|l|}{ Mainland } \\
\hline Arusha & 84 & 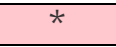 & 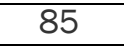 & 5.5 & 57.4 & * & 55.1 & 50.8 & 72.2 & * & 78.7 & 64.8 & 32.7 & * & 32.8 & 4.8 & 19.1 & * & 19.2 & 14.6 \\
\hline $\begin{array}{l}\text { Dar es } \\
\text { Salaam }\end{array}$ & 88.2 & 98.3 & 92.6 & 98.8 & 67.6 & 91.3 & 78 & 93.6 & 87.4 & 98 & 92.1 & 97.5 & 32 & 39.5 & 35.3 & 38.1 & 20.8 & 36.8 & 27.8 & 34.9 \\
\hline Dodoma & * & * & 82.6 & 78 & * & * & 45.3 & 49.3 & * & * & 83.5 & 73.9 & 55.5 & 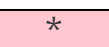 & 49.6 & 52.8 & * & * & 25.9 & 22.1 \\
\hline Geita & .6 & 5.7 & 2 & 2.5 & 4 & 261 & 3 & & 54.3 & 3.1 & .1 & 73.3 & 26 & 42.1 & 2 & 18 & 11.7 & 3.5 & 9.1 & 4.9 \\
\hline Iringa & 3.1 & & & & & 6.3 & 67.5 & 12 & 91.3 & 93.2 & 92.4 & 97 & 42 & 27 & 0.0 & 44 & 33.7 & 23.8 & 28 & 38.3 \\
\hline Kagera & 2.2 & 9 & .2 & 9 & & c & 68.6 & 58.7 & 67.6 & 73 & 69.6 & 78.9 & 36.5 & 41.3 & 38.3 & 36.4 & 20.9 & 16.2 & 19.1 & 21.3 \\
\hline Katavi & .1 & & & & & 5.7 & 36 & & 83.6 & 86.2 & 84.7 & 83.8 & 34 & & 36.2 & 5.2 & 6.8 & 14.1 & 9.9 & 21.6 \\
\hline Kigoma & 87.7 & & & 0.4 & 56. & 57 & 56. & 67. & 89.1 & 90.9 & 89.9 & 85.6 & 35. & 60 & 46 & 40.1 & 22 & 38.1 & 28.8 & 14.7 \\
\hline Kilimanjar & 89.3 & 97.5 & & & 677 & 89.6 & 76.5 & 89 & 94.3 & 92.8 & 93.7 & 96.7 & 37.7 & 40 & 38.8 & 71.4 & 26.4 & 38.3 & 31.2 & 61.9 \\
\hline Lindi & 91.7 & & 1.2 & 97.4 & 6 & * & 63. & 3.3 & 84 & 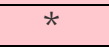 & 87 & 90.3 & 39 & 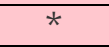 & 0.8 & 25.1 & 28.2 & * & 27.2 & 21.7 \\
\hline Manyara & 66.9 & 64.2 & 5 & 7 & 41.4 & 118 & 44.6 & & 71.9 & 74.3 & 72.6 & 77.7 & 33 & 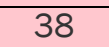 & 35.1 & 36.7 & 17.4 & 15.6 & 16.9 & 18.3 \\
\hline Mara & 0.2 & & & & & & 60 & & 79.7 & 62.9 & & 75.9 & 41 & 31 & 37.3 & 39.7 & 23.1 & 11 & 18.4 & 26.4 \\
\hline Mbey & 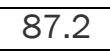 & & & & & & 72 & & 85 & 86.1 & 85.9 & 89.7 & 45 & 51 & 48 & 57.1 & 32.1 & 30 & 31.5 & 43.7 \\
\hline Morogoro & 100 & 93.2 & 96.3 & 87 & 75.5 & 71.2 & 73.2 & & 87.6 & 82.2 & 84.6 & 88.2 & 39.1 & 49.9 & 45 & 49.4 & 23.2 & 35.2 & 29.8 & 38.9 \\
\hline Mtwara & 93.8 & * & 94.4 & & 75 & * & 78 & & 91.1 & * & 94.2 & 96.6 & 25 & * & 28 & 41 & 20.6 & * & 24.8 & 32.3 \\
\hline Mwan & & 72 & & & & 57 & & & & 81.3 & & 83.4 & & 19 & & 18 & 7.3 & 10.3 & 8.4 & 12.1 \\
\hline Njombe & 94.3 & * & 96.8 & 100 & .9 & * & 73.1 & & 86.8 & * & 88.8 & 97.9 & 44.4 & * & 54.1 & 69.3 & 27.1 & * & 37.2 & 33.3 \\
\hline Pwani & 96.8 & $\pi$ & 9 & 97. & 82.3 & * & 82 & & 94.7 & * & 94.7 & 97.8 & 46 & 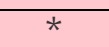 & 47.6 & 49.1 & 35.5 & * & 39.7 & 41.4 \\
\hline Rukwa & & & & & & & & & & * & 84.7 & & & * & (.5 & 29.8 & 23.9 & * & 17 & 17.8 \\
\hline Ruvuma & 90.9 & 98.9 & 94.1 & 95.8 & 0. & 60.7 & 60.9 & & 88.7 & 87 & 88 & 91.2 & 48.8 & 31.3 & 41.8 & 38.2 & 26.9 & 25.3 & 26.2 & 22.7 \\
\hline Shinyanga & 92.8 & 95.8 & 94 & 89.5 & 45.9 & 44.1 & 45. & & 87.3 & 77.4 & 83.3 & 73.8 & 35.7 & 32.4 & 34.4 & 29.2 & 20.4 & 23.2 & 21.6 & 18 \\
\hline Simiyu & 74 & & & & & & & & & 64.9 & & 77 & $2 \perp$ & & 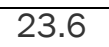 & 34 & 2.4 & 11.6 & 6.2 & 9.4 \\
\hline Singida & 91.2 & 100 & 94.9 & 92.8 & 54.2 & 56.9 & 55.3 & & 88.1 & 90 & 88.9 & 90.2 & 33.8 & 55.6 & 42.9 & 33.5 & 11.7 & 32.6 & 20.4 & 19.1 \\
\hline Tabora & 86.2 & 95.3 & 89.6 & 91.3 & 57.9 & 51.6 & 55.6 & 49.4 & 86.6 & 79.3 & 83.9 & 79.8 & 43.4 & 38.5 & 41.6 & 43 & 27.5 & 22.3 & 25.5 & 18.4 \\
\hline Tanga & 75.4 & 78 & 76.5 & 76.1 & 67.3 & 54.5 & 61.8 & 50.5 & 85.7 & 91.6 & 88.2 & 84.3 & 29.9 & 33.7 & 31.5 & 44.2 & 23.3 & 26.2 & 24.5 & 17.2 \\
\hline
\end{tabular}




\begin{tabular}{|c|c|c|c|c|c|c|c|c|c|c|c|c|c|c|c|c|c|c|c|c|}
\hline \multirow[t]{2}{*}{ Region } & \multicolumn{4}{|c|}{$\begin{array}{l}\text { Are willing to care for a family } \\
\text { member with the AIDS virus in } \\
\text { the respondent's home }\end{array}$} & \multicolumn{4}{|c|}{$\begin{array}{c}\text { Would buy fresh vegetables from } \\
\text { shopkeeper who has the AIDS } \\
\text { virus }\end{array}$} & \multicolumn{4}{|c|}{$\begin{array}{l}\text { Say that a female teacher with } \\
\text { the AIDS virus who is not sick } \\
\text { should be allowed to continue } \\
\text { teaching }\end{array}$} & \multicolumn{4}{|c|}{$\begin{array}{l}\text { Would not want to keep secret } \\
\text { that a family member got } \\
\text { infected with the AIDS virus }\end{array}$} & \multicolumn{4}{|c|}{$\begin{array}{l}\text { Percent expressing } \\
\text { acceptance on all four } \\
\text { indicators }\end{array}$} \\
\hline & $\begin{array}{l}15-17 \\
\text { years }\end{array}$ & $\begin{array}{l}18-19 \\
\text { years }\end{array}$ & $\begin{array}{l}15-19 \\
\text { years }\end{array}$ & $\begin{array}{l}20-24 \\
\text { years }\end{array}$ & $\begin{array}{l}15-17 \\
\text { years }\end{array}$ & $\begin{array}{l}18-19 \\
\text { years }\end{array}$ & $\begin{array}{l}15-19 \\
\text { years }\end{array}$ & $\begin{array}{l}20-24 \\
\text { years }\end{array}$ & $\begin{array}{l}15-17 \\
\text { years }\end{array}$ & $\begin{array}{l}18-19 \\
\text { years }\end{array}$ & $\begin{array}{l}15-19 \\
\text { years }\end{array}$ & $\begin{array}{l}20-24 \\
\text { years }\end{array}$ & $\begin{array}{l}15-17 \\
\text { years }\end{array}$ & $\begin{array}{l}18-19 \\
\text { years }\end{array}$ & $\begin{array}{c}15- \\
19 \\
\text { years } \\
\end{array}$ & $\begin{array}{c}20- \\
24 \\
\text { years }\end{array}$ & $\begin{array}{c}15- \\
17 \\
\text { years } \\
\end{array}$ & $\begin{array}{c}18- \\
19 \\
\text { years }\end{array}$ & \begin{tabular}{|c|}
$15-$ \\
19 \\
years \\
\end{tabular} & $\begin{array}{c}20- \\
24 \\
\text { years }\end{array}$ \\
\hline \multicolumn{21}{|l|}{ Zanzibar } \\
\hline $\begin{array}{c}\text { Kaskazini } \\
\text { Unguja }\end{array}$ & 86.9 & 92.4 & 88.8 & 91.6 & 42.2 & 57.6 & 47.5 & 73.5 & 78.9 & 76 & 77.9 & 87.6 & 58.3 & 57.7 & 58.1 & 59.3 & 32.4 & 44.8 & 36.6 & 43.6 \\
\hline $\begin{array}{l}\text { Kusini } \\
\text { Unguja }\end{array}$ & 96.7 & * & 96.4 & 97.9 & 64.7 & * & 66.5 & 81 & 88.4 & * & 92.8 & 98.5 & 35.7 & * & 48.9 & 69.3 & 23.2 & * & 31.2 & 58.7 \\
\hline $\begin{array}{c}\text { Mjini } \\
\text { Magharibi }\end{array}$ & 98.1 & 97 & 97.6 & 98.4 & 57.9 & 91.5 & 72.5 & 81.1 & 96 & 96.4 & 96.2 & 98.3 & 51.8 & 62.6 & 56.5 & 70.2 & 31.5 & 58.6 & 43.3 & 54.5 \\
\hline $\begin{array}{c}\text { Kaskazini } \\
\text { Pemba }\end{array}$ & 74.2 & 79.8 & 76.3 & 86.7 & 32.9 & 49.5 & 39 & 55.7 & 78.1 & 90.1 & 82.6 & 89.1 & 40.4 & 55.7 & 46.1 & 58.7 & 9.8 & 29.8 & 17.2 & 35.6 \\
\hline $\begin{array}{l}\text { Kusini } \\
\text { Pemba }\end{array}$ & 95.2 & 95.8 & 95.5 & 89.8 & 60.3 & 42 & 53.2 & 48.5 & 90.1 & 95.8 & 92.3 & 90 & 41.6 & 63.7 & 50.2 & 46.1 & 19.7 & 25.8 & 22 & 26.2 \\
\hline Mainland & 85.7 & 92.6 & 88.5 & 91.2 & 57.6 & 63.6 & 60.1 & 64.4 & 82 & 83.9 & 82.8 & 85.6 & 35.7 & 39.4 & 37.2 & 39.8 & 20.5 & 25.3 & 22.5 & 24.6 \\
\hline Zanzibar & 92.9 & 94.3 & 93.5 & 95 & 53.2 & 77.1 & 63 & 72.6 & 90.4 & 94.1 & 91.9 & 94.9 & 48.7 & 61.8 & 54.1 & 64.1 & 26.5 & 49.6 & 36 & 47.2 \\
\hline Urban & 94.9 & 97.7 & 96 & 97.3 & 73.7 & 84.4 & 77.8 & 85.7 & 89.9 & 95.1 & 91.9 & 95.6 & 38.1 & 46.4 & 41.3 & 43 & 28.3 & 38.6 & 32.2 & 35.7 \\
\hline Rural & 82.5 & 90.9 & 86 & 89.1 & 51.1 & 57.2 & 53.6 & 56.8 & 79.3 & 80.6 & 79.9 & 82.4 & 35.4 & 38.2 & 36.6 & 40 & 17.8 & 22 & 19.6 & 21.7 \\
\hline National & 86 & 92.6 & 88.7 & 91.4 & 57.5 & 64.2 & 60.2 & 64.8 & 82.3 & 84.3 & 83.1 & 86 & 36.2 & 40.3 & 37.9 & 40.8 & 20.8 & 26.3 & 23 & 25.6 \\
\hline
\end{tabular}




\begin{tabular}{|c|c|c|c|c|c|c|c|c|c|c|c|c|c|c|c|c|c|c|c|c|}
\hline \multirow[b]{2}{*}{ Region } & \multicolumn{4}{|c|}{ Know where to get an HIV test } & \multicolumn{4}{|c|}{ Ever tested } & \multicolumn{4}{|c|}{ Ever tested and received results } & \multicolumn{4}{|c|}{ Tested in the past 12 months } & \multicolumn{4}{|c|}{$\begin{array}{l}\text { Tested and received results in } \\
\text { past } 12 \text { months }\end{array}$} \\
\hline & $\begin{array}{l}15-17 \\
\text { years }\end{array}$ & $\begin{array}{l}18-19 \\
\text { years }\end{array}$ & $\begin{array}{l}15-19 \\
\text { years }\end{array}$ & $\begin{array}{l}20-24 \\
\text { years }\end{array}$ & $\begin{array}{l}15-17 \\
\text { years }\end{array}$ & $\begin{array}{l}18-19 \\
\text { years }\end{array}$ & $\begin{array}{l}15-19 \\
\text { years }\end{array}$ & $\begin{array}{l}20-24 \\
\text { years }\end{array}$ & $\begin{array}{l}15-17 \\
\text { years }\end{array}$ & $\begin{array}{c}18-19 \\
\text { years }\end{array}$ & $\begin{array}{l}15-19 \\
\text { years }\end{array}$ & $\begin{array}{l}20-24 \\
\text { years }\end{array}$ & $\begin{array}{l}15-17 \\
\text { years }\end{array}$ & $\begin{array}{l}18-19 \\
\text { years }\end{array}$ & $\begin{array}{l}15-19 \\
\text { years }\end{array}$ & $\begin{array}{l}20-24 \\
\text { years }\end{array}$ & $\begin{array}{l}15-17 \\
\text { years }\end{array}$ & $\begin{array}{l}18-19 \\
\text { years }\end{array}$ & $\begin{array}{l}15-19 \\
\text { years }\end{array}$ & $\begin{array}{l}20-24 \\
\text { years }\end{array}$ \\
\hline \multicolumn{21}{|l|}{ Mainland } \\
\hline Arusha & 71.2 & 85 & 76.3 & 90.1 & 24.5 & 57.9 & 36.7 & 70.5 & 17.7 & 54 & 30.9 & 66.1 & 18.7 & 40.2 & 26.6 & 42.7 & 15 & 40.2 & 24.2 & 42.7 \\
\hline $\begin{array}{l}\text { Dar es } \\
\text { Salaam }\end{array}$ & 93.4 & 96.2 & 94.3 & 96 & 32.9 & 61.4 & 42.1 & 72.7 & 29.5 & 61.4 & 39.8 & 70.8 & 18.2 & 41 & 25.6 & 42.4 & 18.2 & 41 & 25.6 & 42.4 \\
\hline Dodoma & 96.4 & 100 & 97.3 & 98.2 & 22.6 & 57.4 & 31.2 & 64.7 & 17.6 & 57.4 & 27.5 & 64.7 & 13.1 & 18.5 & 14.4 & 32 & 10.3 & 18.5 & 12.3 & 32 \\
\hline Iringa & 87.6 & 82.1 & 85.4 & 94.3 & 28.8 & 47.7 & 36.7 & 66.2 & 21.8 & 39.9 & 29.3 & 59.3 & 22.5 & 33.6 & 27.1 & 44.6 & 15.4 & 33.6 & 23 & 43.2 \\
\hline Kagera & 81 & 90.8 & 84.7 & 98.2 & 22.3 & 37.4 & 28 & 76.3 & 20.7 & 35.1 & 26.1 & 72.8 & 15.9 & 25.9 & 19.7 & 44.1 & 14.3 & 25.9 & 18.7 & 42.9 \\
\hline Kigoma & 88.9 & 87.4 & 88.5 & 94.6 & 17.1 & 27.9 & 20.1 & 86.4 & 17.1 & 27.9 & 20.1 & 82.1 & 14.2 & 23.8 & 16.8 & 56.3 & 14.2 & 23.8 & 16.8 & 53.2 \\
\hline Kilimanjaro & 86.3 & 100 & 90.4 & 97.7 & 26 & 73 & 40.6 & 81 & 26 & 69.1 & 39.4 & 78.8 & 9.7 & 42 & 19.8 & 46.2 & 9.7 & 42 & 19.8 & 46.2 \\
\hline Lindi & * & 90.7 & 93.8 & 95.1 & 35.2 & 85.8 & 59.8 & 75.5 & 31.8 & 74.6 & 52.6 & 69.2 & 35.2 & 46.4 & 40.6 & 33.2 & 31.8 & 35.2 & 33.5 & 33.2 \\
\hline Manyara & 63.1 & 89.3 & 73.5 & 78.7 & 11.6 & 68.6 & 33 & 60.8 & 9.2 & 68.6 & 31.6 & 58.2 & 9.5 & 56.6 & 27.2 & 34.5 & 7.1 & 56.6 & 25.7 & 31.8 \\
\hline Mara & 85.8 & 81.9 & 84.4 & 89.4 & 23.6 & 59.4 & 36.1 & 59.7 & 19.7 & 59.4 & 33.6 & 57.8 & 19.1 & 46.9 & 28.8 & 29.6 & 17.1 & 46.9 & 27.5 & 29.6 \\
\hline Mbeya & 65.5 & 82.7 & 70.8 & 92.6 & 17.8 & 42.8 & 25.4 & 65.9 & 15.2 & 39.5 & 22.6 & 61.2 & 12.6 & 38.2 & 20.4 & 34.3 & 12.6 & 34.9 & 19.4 & 31.1 \\
\hline Morogoro & 80.8 & 92 & 86.4 & 91.6 & 24.3 & 57 & 40.5 & 69.1 & 24.3 & 54.5 & 39.2 & 69.1 & 14.6 & 40 & 27.2 & 40.5 & 14.6 & 40 & 27.2 & 40.5 \\
\hline Mtwara & 84.3 & 95.8 & 88.4 & 98.4 & 29.1 & 39.8 & 32.8 & 89.3 & 24.6 & 35.6 & 28.4 & 85.5 & 12.4 & 16.3 & 13.8 & 37.7 & 10.2 & 16.3 & 12.3 & 37.7 \\
\hline Mwanza & 57.1 & 73.3 & 62.9 & 86.7 & 10.6 & 37.9 & 20.4 & 59.6 & 10.6 & 37.9 & 20.4 & 55.2 & 8.7 & 28.6 & 15.8 & 35.2 & 8.7 & 28.6 & 15.8 & 33.3 \\
\hline Pwani & 88.2 & 100 & 93.1 & 93.9 & 24.3 & 34.9 & 28.7 & 78 & 12.6 & 34.9 & 21.9 & 71.1 & 24.3 & 21.7 & 23.2 & 52 & 12.6 & 21.7 & 16.4 & 46.3 \\
\hline Rukwa & 37.3 & 91.2 & 56.2 & 80.2 & 8.4 & 60.2 & 26.5 & 49.4 & 5.9 & 60.2 & 24.9 & 47.1 & 1 & 31.5 & 11.7 & 29.2 & 1 & 31.5 & 11.7 & 29.2 \\
\hline Ruvuma & 78.2 & 100 & 85.5 & 97.4 & 20.2 & 83 & 41.3 & 84.4 & 17.7 & 83 & 39.7 & 84.4 & 20.2 & 58.4 & 33.1 & 62.5 & 17.7 & 58.4 & 31.4 & 62.5 \\
\hline Shinyanga & 89.1 & 100 & 93.9 & 98.2 & 20.3 & 52.6 & 34.2 & 76.1 & 20.3 & 46.6 & 31.6 & 71.7 & 13.6 & 33.2 & 22.1 & 26.9 & 13.6 & 27.1 & 19.5 & 23.4 \\
\hline Singida & 90.1 & 89.4 & 89.9 & 97.5 & 24.9 & 39.3 & 28.7 & 73.7 & 18.5 & 39.3 & 24.1 & 69.9 & 17.5 & 34.5 & 22.1 & 41.2 & 12.8 & 34.5 & 18.6 & 41.2 \\
\hline Tabora & 89.6 & 94.7 & 91.6 & 99.4 & 23.2 & 37.6 & 28.8 & 70.4 & 21.1 & 35 & 26.4 & 64.9 & 21 & 26.5 & 23.1 & 40 & 18.8 & 23.8 & 20.8 & 35.7 \\
\hline Tanga & 84.9 & 86.3 & 85.3 & 96.7 & 29.3 & 53.9 & 36.7 & 76 & 26.2 & 53.9 & 34.5 & 66.7 & 27.5 & 41.8 & 31.8 & 41.2 & 24.3 & 41.8 & 29.6 & 35.8 \\
\hline
\end{tabular}
139 


\begin{tabular}{|c|c|c|c|c|c|c|c|c|c|c|c|c|c|c|c|c|c|c|c|c|}
\hline \multirow[b]{2}{*}{ Region } & \multicolumn{4}{|c|}{ Know where to get an HIV test } & \multicolumn{4}{|c|}{ Ever tested } & \multicolumn{4}{|c|}{ Ever tested and received results } & \multicolumn{4}{|c|}{ Tested in the past 12 months } & \multicolumn{4}{|c|}{$\begin{array}{l}\text { Tested and received results in } \\
\text { past } 12 \text { months }\end{array}$} \\
\hline & $\begin{array}{l}15-17 \\
\text { years }\end{array}$ & $\begin{array}{l}18-19 \\
\text { years }\end{array}$ & $\begin{array}{l}15-19 \\
\text { years }\end{array}$ & $\begin{array}{l}20-24 \\
\text { years }\end{array}$ & $\begin{array}{l}15-17 \\
\text { years }\end{array}$ & $\begin{array}{l}18-19 \\
\text { years }\end{array}$ & $\begin{array}{l}15-19 \\
\text { years }\end{array}$ & $\begin{array}{l}20-24 \\
\text { years }\end{array}$ & $\begin{array}{l}15-17 \\
\text { years }\end{array}$ & $\begin{array}{l}18-19 \\
\text { years }\end{array}$ & $\begin{array}{l}15-19 \\
\text { years }\end{array}$ & $\begin{array}{l}20-24 \\
\text { years }\end{array}$ & $\begin{array}{l}15-17 \\
\text { years }\end{array}$ & $\begin{array}{l}18-19 \\
\text { years }\end{array}$ & $\begin{array}{l}15-19 \\
\text { years }\end{array}$ & $\begin{array}{l}20-24 \\
\text { years }\end{array}$ & $\begin{array}{l}15-17 \\
\text { years }\end{array}$ & $\begin{array}{l}18-19 \\
\text { years }\end{array}$ & $\begin{array}{l}15-19 \\
\text { years }\end{array}$ & $\begin{array}{l}20-24 \\
\text { years }\end{array}$ \\
\hline \multicolumn{21}{|l|}{ Zanzibar } \\
\hline $\begin{array}{l}\text { Kaskazini } \\
\text { Unguja }\end{array}$ & 81 & 93.6 & 85.8 & 98.6 & 5.7 & 22.3 & 12 & 59 & 5.7 & 20 & 11.2 & 50.8 & 4.7 & 6.6 & 5.5 & 31.3 & 4.7 & 6.6 & 5.5 & 29.8 \\
\hline $\begin{array}{l}\text { Kusini } \\
\text { Unguja }\end{array}$ & 91.7 & 92.5 & 92 & 100 & 15.9 & 40.2 & 25.6 & 67 & 11 & 40.2 & 22.7 & 65.7 & 11 & 21.3 & 15.1 & 32.1 & 11 & 21.3 & 15.1 & 32.1 \\
\hline $\begin{array}{c}\text { Mjini } \\
\text { Magharibi }\end{array}$ & 78 & 83.5 & 80.2 & 94.8 & 5.2 & 28 & 14.1 & 59.1 & 5.2 & 28 & 14.1 & 57.6 & 2.5 & 22 & 10.1 & 31.7 & 2.5 & 22 & 10.1 & 31.7 \\
\hline $\begin{array}{l}\text { Kaskazini } \\
\text { Pemba }\end{array}$ & 88.1 & 80.5 & 85.4 & 94.2 & 14.3 & 19.9 & 16.2 & 44.7 & 10.4 & 17.6 & 12.9 & 43.4 & 9.3 & 11.3 & 10 & 18.1 & 8.2 & 9 & 8.5 & 16.9 \\
\hline $\begin{array}{l}\text { Kusini } \\
\text { Pemba }\end{array}$ & 78.8 & 83.3 & 80.4 & 96.1 & 11.8 & 23.1 & 15.7 & 45.8 & 9.3 & 20.4 & 13.1 & 44.5 & 10.5 & 20.9 & 14.1 & 28 & 8.1 & 18.2 & 11.5 & 26.8 \\
\hline Mainland & 80.8 & 90.4 & 84.2 & 94.2 & 22.3 & 50.9 & 32.5 & 71.6 & 19.7 & 48.5 & 29.9 & 67.9 & 15.7 & 34.6 & 22.4 & 39.9 & 14 & 33.3 & 20.9 & 38.2 \\
\hline Zanzibar & 81.9 & 85.4 & 83.2 & 95.9 & 9.4 & 25.8 & 15.5 & 55.2 & 7.7 & 24.5 & 13.9 & 52.7 & 6.6 & 17.2 & 10.6 & 28.8 & 5.9 & 16.3 & 9.7 & 28.1 \\
\hline Urban & 90.1 & 95.4 & 92 & 97.5 & 26.7 & 57.3 & 37.5 & 76.4 & 23.9 & 56 & 35.3 & 74.2 & 17 & 38.5 & 24.6 & 47.1 & 16.5 & 37.6 & 24 & 46.3 \\
\hline Rural & 76.9 & 88.1 & 80.9 & 92.7 & 19.8 & 46.9 & 29.5 & 68.5 & 17.2 & 44 & 26.8 & 64 & 14.6 & 32.1 & 20.9 & 35.8 & 12.6 & 30.6 & 19 & 33.7 \\
\hline National & 80.8 & 90.2 & 84.2 & 94.3 & 21.8 & 50 & 31.9 & 71.1 & 19.2 & 47.6 & 29.3 & 67.4 & 15.3 & 33.9 & 22 & 39.5 & 13.7 & 32.7 & 20.5 & 37.9 \\
\hline
\end{tabular}




\begin{tabular}{|c|c|c|c|c|c|c|c|c|c|c|c|c|c|c|c|c|c|c|c|c|}
\hline \multirow[b]{2}{*}{ Region } & \multicolumn{4}{|c|}{ Know where to get an HIV test } & \multicolumn{4}{|c|}{ Ever tested } & \multicolumn{4}{|c|}{ Ever tested and received results } & \multicolumn{4}{|c|}{ Tested in the past 12 months } & \multicolumn{4}{|c|}{$\begin{array}{c}\text { Tested and received results in } \\
\text { past } 12 \text { months }\end{array}$} \\
\hline & $\begin{array}{c}15- \\
17 \\
\text { years }\end{array}$ & $\begin{array}{c}18- \\
19 \\
\text { years }\end{array}$ & $\begin{array}{c}15- \\
19 \\
\text { years }\end{array}$ & $\begin{array}{c}20- \\
24 \\
\text { years }\end{array}$ & $\begin{array}{c}15- \\
17 \\
\text { years }\end{array}$ & $\begin{array}{c}18- \\
19 \\
\text { years }\end{array}$ & $\begin{array}{c}15- \\
19 \\
\text { years }\end{array}$ & $\begin{array}{c}20- \\
24 \\
\text { years }\end{array}$ & $\begin{array}{c}15- \\
17 \\
\text { years }\end{array}$ & $\begin{array}{c}18- \\
19 \\
\text { years }\end{array}$ & $\begin{array}{c}15- \\
19 \\
\text { years }\end{array}$ & $\begin{array}{c}20- \\
24 \\
\text { years }\end{array}$ & $\begin{array}{c}15- \\
17 \\
\text { years }\end{array}$ & $\begin{array}{c}18- \\
19 \\
\text { years }\end{array}$ & $\begin{array}{c}15- \\
19 \\
\text { years }\end{array}$ & $\begin{array}{c}20- \\
24 \\
\text { years }\end{array}$ & $\begin{array}{c}15- \\
17 \\
\text { years }\end{array}$ & $\begin{array}{c}18- \\
19 \\
\text { years }\end{array}$ & $\begin{array}{c}15- \\
19 \\
\text { years }\end{array}$ & $\begin{array}{l}20-24 \\
\text { years }\end{array}$ \\
\hline \multicolumn{21}{|l|}{ Mainland } \\
\hline Arusha & * & * & * & * & * & * & * & * & * & * & * & * & * & * & * & * & * & * & * & 32.2 \\
\hline $\begin{array}{l}\text { Dar es } \\
\text { Salaam }\end{array}$ & * & * & 95.1 & * & * & * & 21.2 & * & * & * & 21.2 & * & * & * & 17.8 & * & * & * & 17.8 & 41.4 \\
\hline Dodoma & * & * & * & * & * & * & * & * & * & * & * & * & * & * & * & * & * & * & * & 20.5 \\
\hline Iringa & * & * & 86.7 & * & * & * & 35.3 & * & * & * & 31.6 & * & * & * & 24.3 & * & * & * & 20.6 & 23.5 \\
\hline Kagera & * & * & 91 & * & * & * & 14.3 & * & * & * & 14.3 & * & * & * & 8.6 & * & * & * & 8.6 & 16.8 \\
\hline Kigoma & * & * & * & * & * & * & * & * & * & * & * & * & * & * & * & * & * & * & * & 38.9 \\
\hline Kilimanjaro & * & * & 86.8 & * & * & * & 27.3 & * & * & * & 23.9 & * & * & * & 23.9 & * & * & * & 23.9 & 68.7 \\
\hline Lindi & * & * & * & * & * & * & * & * & * & * & * & * & * & * & * & * & * & * & * & 25.1 \\
\hline Manyara & * & * & * & * & * & * & * & * & * & * & * & * & * & * & * & * & * & * & * & 32.1 \\
\hline Mara & * & * & 82.9 & * & * & * & 15.7 & * & * & * & 12.4 & * & * & * & 15.7 & * & * & * & 12.4 & 31.5 \\
\hline Mbeya & * & * & 66.7 & * & * & * & 10.1 & * & * & * & 3.3 & * & * & * & 10.1 & * & * & * & 3.3 & 22.9 \\
\hline Morogoro & * & * & 67.7 & * & * & * & 11.1 & * & * & * & 7.7 & * & * & * & 11.1 & * & * & * & 7.7 & 21.5 \\
\hline Mtwara & * & * & * & * & * & * & * & * & * & * & * & * & * & * & * & * & * & * & * & 18.2 \\
\hline Mwanza & 70 & * & 73.8 & 84.8 & 19.6 & * & 17.4 & 45.7 & 16 & * & 12.7 & 45.7 & 12.3 & * & 12.5 & 27.5 & 12.3 & * & 10.3 & 27.5 \\
\hline Pwani & * & * & * & * & * & * & * & * & * & * & * & * & * & * & * & * & * & * & * & 18.9 \\
\hline Rukwa & * & * & * & * & * & * & * & * & * & * & * & * & * & * & * & * & * & * & * & 18.2 \\
\hline Ruvuma & * & * & * & * & * & * & * & * & * & * & 41.4 & * & * & * & * & * & * & * & * & 55.5 \\
\hline Shinyanga & * & * & 66.6 & * & * & * & 23 & * & * & * & 23 & * & * & * & 10 & * & * & * & 10 & 14.3 \\
\hline Singida & * & * & 88 & * & * & * & 20.4 & * & * & * & 20.4 & * & * & * & 14.6 & * & * & * & 14.6 & 25.1 \\
\hline Tabora & * & * & 74.3 & * & * & * & 27.6 & * & * & * & 26.5 & * & * & * & 19.7 & * & * & * & 18.6 & 29.9 \\
\hline Tanga & * & * & * & * & * & * & * & * & * & * & * & * & * & * & * & * & * & * & * & 57.4 \\
\hline
\end{tabular}


Table 37A-2: HIV Testing among Males Ages 15-24, Percent (DHS 2010)

\begin{tabular}{|c|c|c|c|c|c|c|c|c|c|c|c|c|c|c|c|c|c|c|c|c|}
\hline \multirow[b]{2}{*}{ Region } & \multicolumn{4}{|c|}{ Know where to get an HIV test } & \multicolumn{4}{|c|}{ Ever tested } & \multicolumn{4}{|c|}{ Ever tested and received results } & \multicolumn{4}{|c|}{ Tested in the past 12 months } & \multicolumn{4}{|c|}{$\begin{array}{l}\text { Tested and received results in } \\
\text { past } 12 \text { months }\end{array}$} \\
\hline & $\begin{array}{c}15- \\
17 \\
\text { years }\end{array}$ & $\begin{array}{c}18- \\
19 \\
\text { years }\end{array}$ & $\begin{array}{c}15- \\
19 \\
\text { years }\end{array}$ & $\begin{array}{c}20- \\
24 \\
\text { years }\end{array}$ & $\begin{array}{c}15- \\
17 \\
\text { years }\end{array}$ & $\begin{array}{c}18- \\
19 \\
\text { years }\end{array}$ & $\begin{array}{c}15- \\
19 \\
\text { years }\end{array}$ & $\begin{array}{c}20- \\
24 \\
\text { years }\end{array}$ & $\begin{array}{c}15- \\
17 \\
\text { years }\end{array}$ & $\begin{array}{c}18- \\
19 \\
\text { years }\end{array}$ & $\begin{array}{c}15- \\
19 \\
\text { years }\end{array}$ & $\begin{array}{c}20- \\
24 \\
\text { years }\end{array}$ & $\begin{array}{c}15- \\
17 \\
\text { years }\end{array}$ & $\begin{array}{c}18- \\
19 \\
\text { years }\end{array}$ & $\begin{array}{c}15- \\
19 \\
\text { years }\end{array}$ & $\begin{array}{c}20- \\
24 \\
\text { years }\end{array}$ & $\begin{array}{c}15- \\
17 \\
\text { years }\end{array}$ & $\begin{array}{c}18- \\
19 \\
\text { years }\end{array}$ & $\begin{array}{c}15- \\
19 \\
\text { years }\end{array}$ & $\begin{array}{l}20-24 \\
\text { years }\end{array}$ \\
\hline \multicolumn{21}{|l|}{ Zanzibar } \\
\hline $\begin{array}{c}\text { Kaskazini } \\
\text { Unguja }\end{array}$ & 71.8 & * & 73.7 & * & 11.2 & * & 14 & * & 7.5 & * & 11.6 & * & 11.2 & * & 14 & * & 7.5 & * & 11.6 & * \\
\hline $\begin{array}{l}\text { Kusini } \\
\text { Unguja }\end{array}$ & * & * & 71.4 & 97.5 & * & * & 29.7 & 37.9 & * & * & 29.7 & 37.9 & * & * & 15.2 & 21.9 & * & * & 15.2 & 21.9 \\
\hline $\begin{array}{c}\text { Mjini } \\
\text { Magharibi }\end{array}$ & * & * & 83.3 & * & * & * & 5.8 & * & * & * & 5.8 & * & * & * & 5.8 & * & * & * & 5.8 & * \\
\hline $\begin{array}{l}\text { Kaskazini } \\
\text { Pemba }\end{array}$ & * & * & 91.1 & * & * & * & 9 & * & * & * & 9 & * & * & * & 5.9 & * & * & * & 5.9 & * \\
\hline $\begin{array}{l}\text { Kusini } \\
\text { Pemba }\end{array}$ & * & * & 79.3 & 95.7 & * & * & 0 & 50.2 & * & * & 0 & 45.5 & * & * & 0 & 41.8 & * & * & 0 & 37.1 \\
\hline Mainland & 76.9 & 88.7 & 81.4 & 91.6 & 17.6 & 25.7 & 20.7 & 45.1 & 15.6 & 22.7 & 18.3 & 42.6 & 13.1 & 17.2 & 14.7 & 29.1 & 12.1 & 15.1 & 13.2 & 27.9 \\
\hline Zanzibar & 73.1 & 92.5 & 81.1 & 96.9 & 4.3 & 17.9 & 9.9 & 36.1 & 3.5 & 17.9 & 9.5 & 35.1 & 3.2 & 13.8 & 7.6 & 26.8 & 2.5 & 13.8 & 7.1 & 25.9 \\
\hline Urban & 88.5 & 100 & 93.6 & 94.3 & 20.5 & 31.8 & 25.4 & 51 & 20.5 & 27.8 & 23.7 & 48.6 & 19.5 & 23.9 & 21.4 & 35 & 19.5 & 21.7 & 20.5 & 34.3 \\
\hline Rural & 73.4 & 84.3 & 77.3 & 90.7 & 16.3 & 22.7 & 18.6 & 42.2 & 13.7 & 20.3 & 16.1 & 39.7 & 10.8 & 14.3 & 12.1 & 26.4 & 9.5 & 12.3 & 10.5 & 25.2 \\
\hline National & 76.8 & 88.9 & 81.4 & 91.8 & 17.2 & 25.4 & 20.3 & 44.8 & 15.2 & 22.5 & 18 & 42.3 & 12.8 & 17.1 & 14.4 & 29 & 11.8 & 15.1 & 13 & 27.9 \\
\hline
\end{tabular}




\begin{tabular}{|c|c|c|c|c|c|c|c|c|c|c|c|c|c|c|c|c|c|c|c|c|}
\hline \multirow[b]{2}{*}{ Region } & \multicolumn{4}{|c|}{ Know where to get an HIV test } & \multicolumn{4}{|c|}{ Ever tested } & \multicolumn{4}{|c|}{ Ever tested and received results } & \multicolumn{4}{|c|}{ Tested in the past 12 months } & \multicolumn{4}{|c|}{$\begin{array}{l}\text { Tested and received results in } \\
\text { past } 12 \text { months }\end{array}$} \\
\hline & $\begin{array}{c}15- \\
17 \\
\text { years }\end{array}$ & $\begin{array}{c}18- \\
19 \\
\text { years }\end{array}$ & $\begin{array}{c}15- \\
19 \\
\text { years }\end{array}$ & $\begin{array}{c}20- \\
24 \\
\text { years }\end{array}$ & $\begin{array}{c}15- \\
17 \\
\text { years }\end{array}$ & $\begin{array}{c}18- \\
19 \\
\text { years }\end{array}$ & $\begin{array}{c}15- \\
19 \\
\text { years }\end{array}$ & $\begin{array}{c}20- \\
24 \\
\text { years }\end{array}$ & $\begin{array}{c}15- \\
17 \\
\text { years }\end{array}$ & $\begin{array}{c}18- \\
19 \\
\text { years }\end{array}$ & $\begin{array}{c}15- \\
19 \\
\text { years }\end{array}$ & $\begin{array}{c}20- \\
24 \\
\text { years }\end{array}$ & $\begin{array}{c}15- \\
17 \\
\text { years }\end{array}$ & $\begin{array}{c}18- \\
19 \\
\text { years }\end{array}$ & $\begin{array}{c}15- \\
19 \\
\text { years }\end{array}$ & $\begin{array}{c}20- \\
24 \\
\text { years }\end{array}$ & $\begin{array}{c}15- \\
17 \\
\text { years }\end{array}$ & $\begin{array}{c}18- \\
19 \\
\text { years }\end{array}$ & $\begin{array}{c}15- \\
19 \\
\text { years }\end{array}$ & $\begin{array}{l}20-24 \\
\text { years }\end{array}$ \\
\hline \multicolumn{21}{|l|}{ Mainland } \\
\hline Arusha & 86.9 & 79.2 & 84.2 & 89.3 & 32.5 & 57.6 & 41.7 & 77.1 & 27.2 & 55.3 & 37.5 & 67.9 & 25.8 & 49.2 & 34.4 & 56.2 & 25.8 & 49.2 & 34.4 & 54.3 \\
\hline $\begin{array}{c}\text { Dar es } \\
\text { Salaam }\end{array}$ & 69 & 94.5 & 80.2 & 96.7 & 25.2 & 56.3 & 38.8 & 75.6 & 23.4 & 49.4 & 34.8 & 73.2 & 20.1 & 43.2 & 30.2 & 44.1 & 20.1 & 42.1 & 29.7 & 42.5 \\
\hline Dodoma & * & * & 78.6 & 84.9 & * & * & 48.4 & 71.1 & * & * & 40.3 & 68.2 & 40.3 & 47.7 & 43.5 & 25.4 & 30.8 & 47.7 & 38.1 & 25.4 \\
\hline Geita & 58.4 & 78.7 & 64.9 & 93.2 & 15.7 & 44 & 24.6 & 68.9 & 11.6 & 36.4 & 19.4 & 61.2 & 10.9 & 33.7 & 18.1 & 34.9 & 6.8 & 27.9 & 13.4 & 31 \\
\hline Iringa & 84.4 & 100 & 93.4 & 100 & 34.4 & 56.8 & 47.4 & 77.7 & 33.9 & 43.8 & 39.6 & 73.2 & 19.6 & 27.3 & 24.1 & 64.1 & 19 & 25.1 & 22.5 & 59.6 \\
\hline Kagera & 82.1 & 97.5 & 87.8 & 98.4 & 22.3 & 40.5 & 29 & 85.1 & 19.2 & 35.8 & 25.3 & 81 & 20.8 & 37.1 & 26.8 & 40.8 & 19.2 & 32.4 & 24 & 40.8 \\
\hline Katavi & 64.9 & 89.7 & 75.4 & 91.2 & 21.8 & 52.8 & 34.2 & 66.1 & 13.6 & 51 & 28.6 & 59.7 & 19.8 & 45.2 & 29.9 & 53.2 & 11.6 & 43.5 & 24.3 & 46.8 \\
\hline Kigoma & 77 & 80.7 & 78.6 & 95.9 & 13.8 & 45.1 & 27 & 87.3 & 11.9 & 44.3 & 25.6 & 78.6 & 13.8 & 28.3 & 19.9 & 63 & 11.9 & 27.5 & 18.5 & 61.6 \\
\hline Kilimanjaro & 89.3 & 96.9 & 92.4 & 93.8 & 29.1 & 58.7 & 40.9 & 85.5 & 26.7 & 58.7 & 39.5 & 82.1 & 12.8 & 44.1 & 25.3 & 57.2 & 12.8 & 44.1 & 25.3 & 55.5 \\
\hline Lindi & 87.8 & * & 91.5 & 100 & 44 & * & 59.4 & 90.1 & 35 & * & 52.6 & 83.3 & 21.9 & 70.6 & 36.7 & 55.8 & 17.1 & 68.9 & 32.8 & 53.6 \\
\hline Manyara & 62.4 & 92.2 & 71.6 & 94 & 8.9 & 48.9 & 21.1 & 71.3 & 8.9 & 47.2 & 20.5 & 68.3 & 8.9 & 37.2 & 17.5 & 51.2 & 8.9 & 35.4 & 17 & 48.1 \\
\hline Mara & 73.3 & 92.5 & 81.4 & 92.7 & 27.1 & 41.4 & 33.1 & 74.3 & 27.1 & 37 & 31.3 & 70.8 & 15.6 & 29.4 & 21.4 & 51.9 & 15.6 & 27.2 & 20.5 & 50.5 \\
\hline Mbeya & 76.8 & 81.8 & 78.8 & 96.8 & 13.7 & 44.7 & 26.2 & 75.7 & 12.3 & 43 & 24.7 & 66.1 & 9.8 & 38.5 & 21.4 & 46.1 & 8.4 & 36.8 & 19.8 & 40.5 \\
\hline Morogoro & 81.2 & 80.9 & 81 & 96.2 & 29.7 & 49.8 & 40.9 & 79.9 & 26.2 & 46.2 & 37.3 & 66.7 & 23.2 & 23 & 23.1 & 35.2 & 23.2 & 19.4 & 21.1 & 28.8 \\
\hline Mtwara & 76.3 & * & 84.7 & 100 & 35.9 & * & 41.7 & 94.1 & 33.8 & * & 40.3 & 81.8 & 29.8 & 35.4 & 31.7 & 48.3 & 29.8 & 35.4 & 31.7 & 46.2 \\
\hline Mwanza & 73 & 82.5 & 76.6 & 91.4 & 24 & 57.7 & 36.5 & 84.6 & 18.9 & 56.8 & 33 & 79.4 & 19.6 & 47.6 & 30 & 68.3 & 16 & 46.7 & 27.4 & 64.5 \\
\hline Njombe & 90.2 & * & 94.5 & 100 & 29.7 & * & 39.9 & 87.5 & 28.6 & * & 32.5 & 82.7 & 27.5 & 32.6 & 29.7 & 65.3 & 26.4 & 20 & 23.6 & 62.8 \\
\hline
\end{tabular}




\begin{tabular}{|c|c|c|c|c|c|c|c|c|c|c|c|c|c|c|c|c|c|c|c|c|}
\hline \multirow[b]{2}{*}{ Region } & \multicolumn{4}{|c|}{ Know where to get an HIV test } & \multicolumn{4}{|c|}{ Ever tested } & \multicolumn{4}{|c|}{ Ever tested and received results } & \multicolumn{4}{|c|}{ Tested in the past 12 months } & \multicolumn{4}{|c|}{$\begin{array}{l}\text { Tested and received results in } \\
\text { past } 12 \text { months }\end{array}$} \\
\hline & $\begin{array}{c}15- \\
17 \\
\text { years }\end{array}$ & $\begin{array}{c}18- \\
19 \\
\text { years }\end{array}$ & $\begin{array}{c}15- \\
19 \\
\text { years }\end{array}$ & $\begin{array}{c}20- \\
24 \\
\text { years }\end{array}$ & $\begin{array}{c}15- \\
17 \\
\text { years }\end{array}$ & $\begin{array}{c}18- \\
19 \\
\text { years }\end{array}$ & $\begin{array}{c}15- \\
19 \\
\text { years }\end{array}$ & $\begin{array}{c}20- \\
24 \\
\text { years }\end{array}$ & $\begin{array}{c}15- \\
17 \\
\text { years }\end{array}$ & $\begin{array}{c}18- \\
19 \\
\text { years }\end{array}$ & $\begin{array}{c}15- \\
19 \\
\text { years }\end{array}$ & $\begin{array}{c}20- \\
24 \\
\text { years }\end{array}$ & $\begin{array}{c}15- \\
17 \\
\text { years }\end{array}$ & $\begin{array}{c}18- \\
19 \\
\text { years }\end{array}$ & $\begin{array}{c}15- \\
19 \\
\text { years }\end{array}$ & $\begin{array}{c}20- \\
24 \\
\text { years }\end{array}$ & $\begin{array}{c}15- \\
17 \\
\text { years }\end{array}$ & $\begin{array}{c}18- \\
19 \\
\text { years }\end{array}$ & $\begin{array}{c}15- \\
19 \\
\text { years }\end{array}$ & $\begin{array}{l}20-24 \\
\text { years }\end{array}$ \\
\hline Pwani & 88.7 & * & 92.5 & 94.5 & 48.9 & * & 58.4 & 83.7 & 45.8 & * & 54.2 & 76.9 & 42.7 & 47 & 44.1 & 61.7 & 39.5 & 47 & 42 & 60.1 \\
\hline Rukwa & 68.9 & * & 77.9 & 92 & 19.3 & * & 33.5 & 61.9 & 19.3 & * & 26.3 & 45.2 & 19.3 & 43.3 & 29.3 & 35.7 & 19.3 & 32.4 & 24.7 & 30.8 \\
\hline Ruvuma & 82.2 & 87 & 84.1 & 98.4 & 17.3 & 69.2 & 38.7 & 85.1 & 16.3 & 51.5 & 30.8 & 80.3 & 16.2 & 58 & 33.5 & 58.3 & 15.3 & 45 & 27.6 & 58.3 \\
\hline Shinyanga & 74 & 86.2 & 78.9 & 96.8 & 14.5 & 50.2 & 28.8 & 89.9 & 14.5 & 43.2 & 26 & 84.7 & 11 & 23.4 & 16 & 46.4 & 11 & 16.4 & 13.2 & 45.2 \\
\hline Simiyu & 70 & 90.2 & 78.4 & 98.6 & 18.5 & 57.4 & 34.4 & 72.9 & 16.4 & 51.6 & 30.7 & 66.3 & 15.9 & 34.6 & 23.5 & 36.8 & 13.8 & 29.7 & 20.3 & 31.2 \\
\hline Singida & 60.1 & 76 & 66.8 & 89.4 & 7.8 & 36.3 & 19.3 & 74.4 & 7.8 & 33.8 & 18.3 & 70.7 & 6.4 & 19.4 & 11.7 & 53.5 & 6.4 & 16.8 & 10.6 & 49.8 \\
\hline Tabora & 89 & 100 & 93.1 & 98.9 & 15 & 69 & 34.9 & 86.4 & 15 & 65.6 & 33.6 & 84.5 & 12.1 & 65.1 & 31.7 & 58.7 & 12.1 & 61.6 & 30.4 & 58.1 \\
\hline Tanga & 65.3 & 89.8 & 75.8 & 82.6 & 15.6 & 53 & 32.3 & 68.4 & 15.6 & 49.3 & 30.7 & 60.5 & 15.6 & 39.1 & 26.1 & 41.3 & 15.6 & 35.4 & 24.5 & 35.2 \\
\hline \multicolumn{21}{|l|}{ Zanzibar } \\
\hline $\begin{array}{l}\text { Kaskazini } \\
\text { Unguja }\end{array}$ & 71.2 & 96.1 & 79.7 & 92.7 & 11.8 & 29.7 & 18 & 57.5 & 9.7 & 29.7 & 16.7 & 54.7 & 9.7 & 21 & 13.6 & 30.5 & 7.5 & 21 & 12.2 & 29.1 \\
\hline $\begin{array}{l}\text { Kusini } \\
\text { Unguja }\end{array}$ & 87.6 & * & 92.4 & 100 & 22.8 & * & 35.9 & 65.5 & 20 & * & 30.4 & 60.5 & 21.3 & 35.8 & 26.9 & 27.3 & 18.5 & 31.3 & 23.4 & 25.1 \\
\hline $\begin{array}{c}\text { Mjini } \\
\text { Magharibi }\end{array}$ & 88.6 & 94.6 & 91.2 & 97.2 & 16.4 & 32.3 & 23.4 & 64.5 & 16.4 & 23.5 & 19.5 & 63.6 & 9 & 26.3 & 16.5 & 38.2 & 9 & 17.5 & 12.7 & 38.2 \\
\hline $\begin{array}{c}\text { Kaskazini } \\
\text { Pemba }\end{array}$ & 68.1 & 83.4 & 73.8 & 92.2 & 5.7 & 28.1 & 14 & 58.7 & 5.7 & 28.1 & 14 & 58.7 & 2.5 & 22.4 & 9.9 & 31.5 & 2.5 & 22.4 & 9.9 & 31.5 \\
\hline $\begin{array}{l}\text { Kusini } \\
\text { Pemba }\end{array}$ & 84.1 & 87.5 & 85.4 & 95.6 & 5.4 & 18.6 & 10.5 & 60.6 & 5.4 & 10.6 & 7.4 & 60.6 & 5.4 & 15 & 9.1 & 38.9 & 5.4 & 7 & 6 & 38.9 \\
\hline Mainland & 75.5 & 89.2 & 81.1 & 94.7 & 22.1 & 53.8 & 34.9 & 79 & 19.8 & 48.6 & 31.4 & 73.1 & 17.5 & 39.5 & 26.4 & 49.4 & 16 & 36.1 & 24.2 & 46.6 \\
\hline Zanzibar & 83.1 & 92.9 & 87.1 & 96.1 & 13.5 & 31.5 & 20.8 & 62.6 & 13.1 & 24.5 & 17.8 & 61.4 & 8.4 & 24.7 & 15.1 & 36.1 & 8 & 18 & 12.1 & 35.8 \\
\hline Urban & 82.1 & 93.5 & 86.4 & 97.4 & 26.2 & 55 & 37.2 & 82.2 & 25 & 51.1 & 34.9 & 76.8 & 20.5 & 44 & 29.5 & 56 & 20.1 & 41.4 & 28.2 & 54.3 \\
\hline
\end{tabular}


Table 37B-1: $\quad$ HIV Testing among Females Ages 15-24, Percent (THMIS 2011-2012)

\begin{tabular}{|c|c|c|c|c|c|c|c|c|c|c|c|c|c|c|c|c|c|c|c|c|}
\hline \multirow[b]{2}{*}{ Region } & \multicolumn{4}{|c|}{ Know where to get an HIV test } & \multicolumn{4}{|c|}{ Ever tested } & \multicolumn{4}{|c|}{ Ever tested and received results } & \multicolumn{4}{|c|}{ Tested in the past 12 months } & \multicolumn{4}{|c|}{$\begin{array}{l}\text { Tested and received results in } \\
\text { past } 12 \text { months }\end{array}$} \\
\hline & $\begin{array}{c}15- \\
17 \\
\text { years }\end{array}$ & $\begin{array}{c}18- \\
19 \\
\text { years } \\
\end{array}$ & $\begin{array}{c}15- \\
19 \\
\text { years }\end{array}$ & $\begin{array}{c}20- \\
24 \\
\text { years }\end{array}$ & $\begin{array}{c}15- \\
17 \\
\text { years }\end{array}$ & $\begin{array}{c}18- \\
19 \\
\text { years }\end{array}$ & $\begin{array}{c}15- \\
19 \\
\text { years } \\
\end{array}$ & $\begin{array}{c}20- \\
24 \\
\text { years }\end{array}$ & $\begin{array}{c}15- \\
17 \\
\text { years }\end{array}$ & $\begin{array}{c}18- \\
19 \\
\text { years }\end{array}$ & $\begin{array}{c}15- \\
19 \\
\text { years } \\
\end{array}$ & $\begin{array}{c}20- \\
24 \\
\text { years } \\
\end{array}$ & $\begin{array}{c}15- \\
17 \\
\text { years } \\
\end{array}$ & $\begin{array}{c}18- \\
19 \\
\text { years }\end{array}$ & $\begin{array}{c}15- \\
19 \\
\text { years }\end{array}$ & $\begin{array}{c}20- \\
24 \\
\text { years } \\
\end{array}$ & $\begin{array}{c}15- \\
17 \\
\text { years } \\
\end{array}$ & $\begin{array}{c}18- \\
19 \\
\text { years }\end{array}$ & $\begin{array}{c}15- \\
19 \\
\text { years }\end{array}$ & $\begin{array}{l}20-24 \\
\text { years } \\
\end{array}$ \\
\hline Rural & 73.3 & 88 & 79.4 & 93.8 & 20 & 52.3 & 33.4 & 76.9 & 17.4 & 46.5 & 29.4 & 71 & 15.9 & 37.2 & 24.7 & 46.2 & 14 & 33.4 & 22 & 43.1 \\
\hline National & 75.8 & 89.4 & 81.3 & 94.7 & 21.8 & 53 & 34.4 & 78.4 & 19.5 & 47.7 & 30.9 & 72.6 & 17.2 & 38.9 & 26 & 48.9 & 15.7 & 35.4 & 23.7 & 46.2 \\
\hline
\end{tabular}


Table 37B-2: $\quad$ HIV Testing among Males Ages 15-24, Percent (THMIS 2011-2012)

\begin{tabular}{|c|c|c|c|c|c|c|c|c|c|c|c|c|c|c|c|c|c|c|c|c|}
\hline \multirow{2}{*}{ Region } & \multicolumn{4}{|c|}{ Know where to get an HIV test } & \multicolumn{4}{|c|}{ Ever tested } & \multicolumn{4}{|c|}{ Ever tested and received results } & \multicolumn{4}{|c|}{ Tested in the past 12 months } & \multicolumn{4}{|c|}{$\begin{array}{l}\text { Tested and received results in } \\
\text { past } 12 \text { months }\end{array}$} \\
\hline & $\begin{array}{l}15-17 \\
\text { years }\end{array}$ & $\begin{array}{l}18-19 \\
\text { years }\end{array}$ & $\begin{array}{l}15-19 \\
\text { years }\end{array}$ & $\begin{array}{l}20-24 \\
\text { years }\end{array}$ & $\begin{array}{l}15-17 \\
\text { years }\end{array}$ & $\begin{array}{l}18-19 \\
\text { years }\end{array}$ & $\begin{array}{l}15-19 \\
\text { years }\end{array}$ & $\begin{array}{l}20-24 \\
\text { years }\end{array}$ & $\begin{array}{l}15-17 \\
\text { years }\end{array}$ & $\begin{array}{l}18-19 \\
\text { years }\end{array}$ & $\begin{array}{l}15-19 \\
\text { years }\end{array}$ & $\begin{array}{l}20-24 \\
\text { years }\end{array}$ & $\begin{array}{l}15-17 \\
\text { years }\end{array}$ & $\begin{array}{l}18-19 \\
\text { years }\end{array}$ & $\begin{array}{l}15-19 \\
\text { years }\end{array}$ & $\begin{array}{l}20-24 \\
\text { years }\end{array}$ & $\begin{array}{l}15-17 \\
\text { years }\end{array}$ & $\begin{array}{l}18-19 \\
\text { years }\end{array}$ & $\begin{array}{l}15-19 \\
\text { years }\end{array}$ & $\begin{array}{l}20-24 \\
\text { years }\end{array}$ \\
\hline \multicolumn{21}{|l|}{ Mainland } \\
\hline Arusha & 4.8 & * & 74 & 100 & 5.8 & * & 12 & 47.2 & 5.8 & * & 12 & 47.2 & 5.8 & 2 & 2 & 1.5 & 5.8 & 8.2 & 9.2 & 41.5 \\
\hline $\begin{array}{c}\text { Dar es } \\
\text { Salaam }\end{array}$ & 86.4 & 93.3 & 89.8 & 94.6 & 12.8 & 44.5 & 28.2 & 60.5 & 12.8 & 42.6 & 27.3 & 59.8 & 11 & 28.1 & 19.3 & 46.6 & 11 & 26.2 & 18.4 & 45.9 \\
\hline Dodoma & 46 & * & 49.4 & 79.8 & 8.6 & * & 12.6 & 29.9 & 8.6 & * & 12.6 & 29.9 & 8.6 & 4.5 & 7 & 19.6 & 8.6 & 4.5 & 7 & 19.6 \\
\hline Geita & 67.2 & 82.8 & 72.9 & 89.5 & 3 & 10.4 & 5.7 & 35.7 & 2.2 & 10.4 & 5.2 & 31.4 & 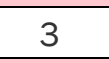 & 8.6 & 5 & 23.1 & 2.2 & 8.6 & 4.5 & 20.8 \\
\hline Iringa & 85.4 & 83.7 & 84.7 & 88.6 & 25.3 & 34.2 & 29 & 39.1 & 23.4 & 34.2 & 27.9 & 38.4 & 18.9 & 32.3 & 24.5 & 29.7 & 18.5 & 32.3 & 24.2 & 29 \\
\hline Kagera & 83.5 & * & 85.4 & 100 & 19.2 & * & 22.1 & 63.8 & 17.7 & * & 21.1 & 63.8 & 14.6 & 18.5 & 15.8 & 51 & 13.1 & 18.5 & 14.9 & 51 \\
\hline Katavi & 72.9 & * & 79.7 & 95.4 & 1.8 & * & 4.3 & 61 & 1.8 & * & 4.3 & 57.3 & 0 & 8.6 & 3.2 & 40.1 & 0 & 8.6 & 3.2 & 40.1 \\
\hline Kigoma & 69.7 & 85.1 & 76.8 & 96.8 & 14.2 & 28.1 & 20.6 & 60.3 & 14.2 & 16.7 & 15.4 & 55.6 & 12.9 & 21.1 & 16.7 & 40.4 & 12.9 & 9.8 & 11.5 & 40.4 \\
\hline Kilimanjaro & 94.4 & 86.9 & 90.9 & 89.7 & 21 & 48.8 & 33.7 & 56 & 19.1 & 47.3 & 32 & 56 & 8.9 & 32.7 & 19.8 & 42.1 & 7 & 32.7 & 18.8 & 42.1 \\
\hline Lindi & 81.3 & * & 82.1 & 94 & 27.4 & * & 25.1 & 70.4 & 21.1 & * & 19.8 & 63 & 16 & 10.4 & 13.9 & 39 & 9.6 & 10.4 & 9.9 & 31.5 \\
\hline Manyara & 69.8 & 90.3 & 80.1 & 89.3 & 17.7 & 45.8 & 31.8 & 34.9 & 15.6 & 42.4 & 29 & 34.9 & 13.3 & 27.6 & 20.5 & 20.5 & 11.1 & 27.6 & 19.4 & 20.5 \\
\hline Mara & 67.7 & 86.1 & 73.4 & 100 & 9.1 & 48.6 & 21.3 & 61.1 & 7.8 & 45.9 & 19.6 & 48.8 & 9.1 & 41.1 & 19 & 52.6 & 7.8 & 38.4 & 17.3 & 43.1 \\
\hline Mbeya & 68.9 & 90.5 & 77.3 & 95.4 & 12 & 24.7 & 17 & 54.2 & 9 & 22.2 & 14.2 & 49.8 & 9.4 & 17.9 & 12.7 & 33.5 & 6.4 & 15.4 & 9.9 & 29.1 \\
\hline Morogoro & 76.1 & 82.7 & 79.4 & 97.5 & 12.2 & 15 & 13.6 & 44.7 & 6.4 & 15 & 10.7 & 38.6 & 8.4 & 4.4 & 6.4 & 28.4 & 2.6 & 4.4 & 3.5 & 25.9 \\
\hline Mtwara & 90.9 & * & 93.8 & 100 & 11 & * & 22.1 & 65.6 & 11 & * & 22.1 & 60.4 & 0 & 13.3 & 4.2 & 41.4 & 0 & 13.3 & 4.2 & 40.1 \\
\hline Mwanza & 72.1 & 89.1 & 79.1 & 91.4 & 11.9 & 12.4 & 12.1 & 44.2 & 11.9 & 12.4 & 12.1 & 42.5 & 11.9 & 12.4 & 12.1 & 33.1 & 11.9 & 12.4 & 12.1 & 33.1 \\
\hline Njombe & 80.3 & * & 84.4 & 97.1 & 38.2 & * & 43.5 & 75.4 & 38.2 & * & 42.4 & 65.2 & 36.5 & 50.6 & 41.1 & 66.9 & 36.5 & 47.1 & 39.9 & 56.7 \\
\hline Pwani & 75.4 & 89.3 & 81.8 & 94.1 & 18.5 & 18.4 & 18.4 & 49.5 & 18.5 & 18.4 & 18.4 & 43.2 & 18.5 & 8.4 & 13.9 & 34.5 & 18.5 & 8.4 & 13.9 & 34.5 \\
\hline Rukwa & 77.5 & * & 84.1 & 93.9 & 4.9 & * & 14.2 & 65.9 & 4.9 & * & 14.2 & 63.3 & 4.9 & 16.6 & 11.2 & 63.3 & 4.9 & 16.6 & 11.2 & 60.8 \\
\hline Ruvuma & 88.4 & * & 92.6 & 97.1 & 24.2 & * & 24.8 & 46.9 & 24.2 & * & 24.8 & 43.6 & 22 & 25.9 & 23.4 & 41.4 & 22 & 25.9 & 23.4 & 39.8 \\
\hline Shinyanga & 71 & * & 74.7 & 93.6 & 20.7 & * & 28 & 48.7 & 20.7 & * & 28 & 48.7 & 20.7 & 41 & 28 & 37.7 & 20.7 & 41 & 28 & 37.7 \\
\hline Simiyu & 66.1 & 64.1 & 65.4 & 88.1 & 21.5 & 29.5 & 24.3 & 46.5 & 19.9 & 29.5 & 23.3 & 45.4 & 14.1 & 29.5 & 19.6 & 41 & 12.6 & 29.5 & 18.6 & 40 \\
\hline Singida & 62.1 & 82.5 & 70.6 & 81.6 & 25 & 22.1 & 23.8 & 42.8 & 23.2 & 22.1 & 22.7 & 41.2 & 20.6 & 16.7 & 19 & 35.6 & 20.6 & 16.7 & 19 & 35.6 \\
\hline
\end{tabular}


Table 37B-2: $\quad$ HIV Testing among Males Ages 15-24, Percent (THMIS 2011-2012)

\begin{tabular}{|c|c|c|c|c|c|c|c|c|c|c|c|c|c|c|c|c|c|c|c|c|}
\hline \multirow{2}{*}{ Region } & \multicolumn{4}{|c|}{ Know where to get an HIV test } & \multicolumn{4}{|c|}{ Ever tested } & \multicolumn{4}{|c|}{ Ever tested and received results } & \multicolumn{4}{|c|}{ Tested in the past 12 months } & \multicolumn{4}{|c|}{$\begin{array}{l}\text { Tested and received results in } \\
\text { past } 12 \text { months }\end{array}$} \\
\hline & $\begin{array}{l}15-17 \\
\text { years }\end{array}$ & $\begin{array}{l}18-19 \\
\text { years }\end{array}$ & $\begin{array}{l}15-19 \\
\text { years }\end{array}$ & $\begin{array}{l}20-24 \\
\text { years }\end{array}$ & $\begin{array}{l}15-17 \\
\text { years }\end{array}$ & $\begin{array}{l}18-19 \\
\text { years }\end{array}$ & $\begin{array}{l}15-19 \\
\text { years }\end{array}$ & $\begin{array}{l}20-24 \\
\text { years }\end{array}$ & $\begin{array}{l}15-17 \\
\text { years }\end{array}$ & $\begin{array}{l}18-19 \\
\text { years }\end{array}$ & $\begin{array}{l}15-19 \\
\text { years }\end{array}$ & $\begin{array}{l}20-24 \\
\text { years }\end{array}$ & $\begin{array}{l}15-17 \\
\text { years }\end{array}$ & $\begin{array}{l}18-19 \\
\text { years }\end{array}$ & $\begin{array}{l}15-19 \\
\text { years }\end{array}$ & $\begin{array}{l}20-24 \\
\text { years }\end{array}$ & $\begin{array}{l}15-17 \\
\text { years }\end{array}$ & $\begin{array}{l}18-19 \\
\text { years }\end{array}$ & $\begin{array}{l}15-19 \\
\text { years }\end{array}$ & $\begin{array}{l}20-24 \\
\text { years }\end{array}$ \\
\hline Tabora & 77.4 & 92.8 & 83.3 & 92.8 & 13.6 & 37.2 & 22.6 & 49.4 & 13.6 & 35.9 & 22.1 & 46.6 & 10.5 & 22.6 & 15.1 & 40 & 10.5 & 22.6 & 15.1 & 38.8 \\
\hline Tanga & 62.2 & * & 70.9 & 96.1 & 26.9 & * & 22.1 & 52.2 & 23.6 & * & 20 & 52.2 & 20.7 & 13.6 & 18.1 & 24.5 & 17.4 & 13.6 & 16.1 & 24.5 \\
\hline \multicolumn{21}{|l|}{ Zanzibar } \\
\hline $\begin{array}{c}\text { Kaskazini } \\
\text { Unguja }\end{array}$ & 65.6 & * & 71.1 & 88.6 & 5 & * & 6 & 26.8 & 5 & * & 6 & 26.8 & 5 & 7.6 & 6 & 20.1 & 5 & 7.6 & 6 & 20.1 \\
\hline $\begin{array}{l}\text { Kusini } \\
\text { Unguja }\end{array}$ & 69.2 & * & 73.7 & 91.1 & 8.5 & * & 11.9 & 42.9 & 8.5 & * & 10.1 & 38.9 & 2.9 & 14.9 & 7 & 26.8 & 2.9 & 9.6 & 5.2 & 22.8 \\
\hline $\begin{array}{c}\text { Mjini } \\
\text { Magharibi }\end{array}$ & 69.4 & * & 63.5 & 97 & 4 & * & 10 & 59.9 & 4 & * & 10 & 56.3 & 2.9 & 11.7 & 6.6 & 37.3 & 2.9 & 11.7 & 6.6 & 36.1 \\
\hline $\begin{array}{c}\text { Kaskazini } \\
\text { Pemba }\end{array}$ & 63.3 & 81.4 & 71.2 & 90.9 & 0 & 17.5 & 7.7 & 14.4 & 0 & 10.5 & 4.6 & 12.9 & 0 & 7.7 & 3.4 & 6.8 & 0 & 7.7 & 3.4 & 6.8 \\
\hline $\begin{array}{l}\text { Kusini } \\
\text { Pemba }\end{array}$ & 72.3 & * & 73.2 & 92.4 & 2.2 & * & 6.1 & 29.2 & 1.1 & * & 5.3 & 29.2 & 2.2 & 15.5 & 6.1 & 19.3 & 1.1 & 15.5 & 5.3 & 19.3 \\
\hline Mainland & 74.1 & 85.8 & 78.8 & 93.2 & 16.1 & 29.7 & 21.5 & 51.7 & 14.9 & 28.2 & 20.2 & 48.8 & 12.9 & 21.4 & 16.3 & 38.7 & 11.8 & 20.2 & 15.2 & 37 \\
\hline Zanzibar & 68.9 & 65.3 & 67.5 & 94.6 & 3.6 & 16.9 & 8.9 & 47.3 & 3.4 & 15.7 & 8.2 & 44.6 & 2.6 & 11.4 & 6.1 & 29.6 & 2.4 & 11.1 & 5.8 & 28.5 \\
\hline Urban & 88.7 & 92.8 & 90.5 & 96.3 & 20.7 & 39.1 & 28.7 & 62.3 & 19.9 & 35.8 & 26.8 & 60.1 & 16.7 & 25.7 & 20.6 & 47 & 15.9 & 22.4 & 18.7 & 45.4 \\
\hline Rural & 69.7 & 82.4 & 74.6 & 92 & 14.2 & 25.9 & 18.7 & 46.9 & 13 & 25 & 17.6 & 43.8 & 11.4 & 19.5 & 14.5 & 34.6 & 10.3 & 19 & 13.6 & 33 \\
\hline National & 73.9 & 85 & 78.4 & 93.3 & 15.7 & 29.3 & 21 & 51.5 & 14.5 & 27.7 & 19.8 & 48.7 & 12.5 & 21.1 & 15.9 & 38.3 & 11.5 & 19.9 & 14.8 & 36.7 \\
\hline
\end{tabular}


Annex Table 38: THMIS 2011-12, Among the De Facto Females and Males Who Were Interviewed and Tested, The Percent Who Tested HIV Positive, by Age

\begin{tabular}{|c|c|c|c|c|}
\hline \multirow{2}{*}{ Region } & \multicolumn{2}{|c|}{ Females } & \multicolumn{2}{|c|}{ Males } \\
\hline & Ages 15-19 & Ages 20-24 & Ages 15-19 & Ages 20-24 \\
\hline \multicolumn{5}{|l|}{ Mainland } \\
\hline Arusha & 1.3 & 1.8 & 0.0 & 0.0 \\
\hline Dar es Salaam & 4.1 & 8.7 & 0.0 & 1.8 \\
\hline Dodoma & 0.0 & 0.0 & 4.6 & 0.0 \\
\hline Geita & 3.4 & 5.6 & 0.0 & 3.2 \\
\hline Iringa & 2.1 & 12.4 & 2.0 & 0.0 \\
\hline Kagera & 1.4 & 3.4 & 1.0 & 6.5 \\
\hline Katavi & 2.1 & 4.7 & 0.0 & 4.2 \\
\hline Kigoma & 0.0 & 2.0 & 5.4 & 0.0 \\
\hline Kilimanjaro & 1.4 & 2.6 & 1.6 & 1.9 \\
\hline Lindi & 1.3 & 4.2 & 0.0 & 4.1 \\
\hline Manyara & 0.0 & 0.0 & 0.0 & 0.0 \\
\hline Mara & 1.5 & 0.0 & 0.0 & 2.5 \\
\hline Mbeya & 2.2 & 6.7 & 0.0 & 0.0 \\
\hline Morogoro & 0.0 & 4.6 & 0.0 & 0.0 \\
\hline Mtwara & 2.6 & 2.1 & 0.0 & 3.6 \\
\hline Mwanza & 1.0 & 2.7 & 0.0 & 2.1 \\
\hline Njombe & 1.5 & 15.5 & 2.0 & 0.0 \\
\hline Pwani & 0.0 & 0.0 & 0.0 & 0.0 \\
\hline Rukwa & 1.8 & 6.3 & 0.0 & 0.0 \\
\hline Ruvuma & 0.6 & 4.1 & 0.0 & 5.6 \\
\hline Shinyanga & 1.1 & 9.3 & 0.0 & 4.5 \\
\hline Simiyu & 0.6 & 5.1 & 0.0 & 1.3 \\
\hline Singida & 0.0 & 2.7 & 1.5 & 0 \\
\hline Tabora & 0.0 & 2.4 & 0.0 & 1.4 \\
\hline Tanga & 0.0 & 3.1 & 0.0 & * \\
\hline Mainland & 1.3 & 4.6 & 0.7 & 1.8 \\
\hline Zanzibar & 0.0 & 0.2 & 1.9 & 0.0 \\
\hline Urban & 1.7 & 6.7 & 2.2 & 2.6 \\
\hline Rural & 1.1 & 3.6 & 0.3 & 1.3 \\
\hline National & 1.3 & 4.4 & 0.8 & 1.7 \\
\hline
\end{tabular}

Notes: Read the first column of data as "Among females interviewed and tested for HIV, percent of 15-19 year old females who tested seropositive," using 2011-12 THMIS.

Figures in highlighted cells are based on 25-50 unweighted cases. Highlighted cells marked with an asterisk are based on less than 25 unweighted cases. 
Annex Table 39: THMIS 2011-12, Among the De Facto Females and Males Who Were Interviewed and Tested, The Percent Who Tested HIV Positive, by Single Year of Age

\begin{tabular}{|c|c|c|c|c|c|c|}
\hline & \multicolumn{2}{|c|}{ Age 15} & \multicolumn{2}{|c|}{ Age 16} & \multicolumn{2}{|c|}{ Age 17} \\
\hline Region & $\begin{array}{l}\text { Females } \\
\text { (\% within } \\
\text { sex for } \\
\text { age) }\end{array}$ & $\begin{array}{l}\text { Males (\% } \\
\text { within sex } \\
\text { for age) }\end{array}$ & $\begin{array}{c}\text { Females (\% } \\
\text { within sex } \\
\text { for age) }\end{array}$ & $\begin{array}{l}\text { Males (\% } \\
\text { within sex } \\
\text { for age) }\end{array}$ & $\begin{array}{c}\text { Females (\% } \\
\text { within sex } \\
\text { for age) }\end{array}$ & $\begin{array}{c}\text { Males (\% } \\
\text { within sex } \\
\text { for age) }\end{array}$ \\
\hline Mainland & 1 & 1.1 & 0.8 & 0.3 & 1.5 & 0 \\
\hline Zanzibar & 0 & 0 & 0 & 0 & 0 & 8.5 \\
\hline Urban & 0 & 3.7 & 1.2 & 1.5 & 2.6 & 0 \\
\hline Rural & 1.3 & 0.3 & 0.7 & 0 & 1 & 0.4 \\
\hline National & 1 & 1.1 & 0.8 & 0.3 & 1.4 & 0.3 \\
\hline
\end{tabular}

\begin{tabular}{|l|c|c|c|c|c|c|}
\hline & \multicolumn{2}{|c|}{ Age 18 } & \multicolumn{2}{c|}{ Age 19 } & \multicolumn{2}{c|}{ Age 20 } \\
\hline & $\begin{array}{c}\text { Females } \\
\text { (\% within } \\
\text { sex for } \\
\text { age) }\end{array}$ & $\begin{array}{c}\text { Males } \% \\
\text { within sex } \\
\text { for age) }\end{array}$ & $\begin{array}{c}\text { Females (\% } \\
\text { within sex } \\
\text { for age) }\end{array}$ & $\begin{array}{c}\text { Males (\% } \\
\text { within sex } \\
\text { for age) }\end{array}$ & $\begin{array}{c}\text { Females (\% } \\
\text { within sex } \\
\text { for age) }\end{array}$ & $\begin{array}{c}\text { Males (\% } \\
\text { within sex } \\
\text { for age) }\end{array}$ \\
\hline Mainland & 2.2 & 0.5 & 1 & 1.9 & 2.7 & 1.2 \\
\hline Zanzibar & 0 & 0 & 0 & 0 & 0.9 & 0 \\
\hline Urban & 3.4 & 0 & 1.4 & 5.8 & 8.1 & 1.3 \\
\hline Rural & 1.8 & 0.6 & 0.8 & 0.4 & 1.1 & 1.1 \\
\hline National & 2.2 & 0.5 & 0.9 & 1.8 & 2.6 & 1.1 \\
\hline
\end{tabular}

\begin{tabular}{|c|c|c|c|c|c|c|}
\hline Region & \multicolumn{2}{|c|}{ Age 21} & \multicolumn{2}{|c|}{ Age 22} & \multicolumn{2}{|c|}{ Age 23} \\
\hline Mainland & $\begin{array}{c}\text { Females } \\
\text { (\% within } \\
\text { sex for } \\
\text { age) }\end{array}$ & $\begin{array}{c}\text { Males (\% } \\
\text { within sex } \\
\text { for age) }\end{array}$ & $\begin{array}{c}\text { Females (\% } \\
\text { within sex } \\
\text { for age) }\end{array}$ & $\begin{array}{l}\text { Males (\% } \\
\text { within sex } \\
\text { for age) }\end{array}$ & $\begin{array}{c}\text { Females (\% } \\
\text { within sex } \\
\text { for age) }\end{array}$ & $\begin{array}{c}\text { Males (\% } \\
\text { within sex } \\
\text { for age) }\end{array}$ \\
\hline Zanzibar & 3.4 & 0.5 & 3.4 & 2 & 5.9 & 3.5 \\
\hline Urban & 0 & 0 & 0 & 0 & 0 & 0 \\
\hline Rural & 3 & 0 & 3 & 3.7 & 5.8 & 8 \\
\hline National & 3.4 & 0.7 & 3.3 & 0.9 & 5.6 & 1.7 \\
\hline & 3.3 & 0.5 & 3.2 & 1.9 & 5.7 & 3.5 \\
\hline
\end{tabular}

\begin{tabular}{|l|c|c|}
\hline & \multicolumn{2}{|c|}{ Age 24 } \\
\hline Region & $\begin{array}{c}\text { Females } \\
\text { (\% within } \\
\text { sex for } \\
\text { age) }\end{array}$ & $\begin{array}{c}\text { Males (\% } \\
\text { within sex } \\
\text { for age) }\end{array}$ \\
\hline Mainland & 8 & 2.2 \\
\hline Zanzibar & 0 & 0 \\
\hline Urban & 13.8 & 1.2 \\
\hline Rural & 4.8 & 2.6 \\
\hline National & 7.7 & 2.1 \\
\hline
\end{tabular}




\begin{tabular}{|c|c|c|c|c|c|c|c|c|}
\hline \multicolumn{9}{|c|}{$\begin{array}{l}\text { Annex Table 40A: Percent of Females and Males Ages 15-24 Who Had 2+ Partners in Past } 12 \text { Months (DHS } \\
\text { 2010) }\end{array}$} \\
\hline \multirow[b]{2}{*}{ Region } & \multicolumn{4}{|c|}{$\begin{array}{ll}\text { Females } \\
\end{array}$} & \multicolumn{4}{|c|}{ Males } \\
\hline & $\begin{array}{l}15-17 \\
\text { years }\end{array}$ & $\begin{array}{l}18-19 \\
\text { years }\end{array}$ & $\begin{array}{l}15-19 \\
\text { years }\end{array}$ & $\begin{array}{l}20-24 \\
\text { years }\end{array}$ & $\begin{array}{l}15-17 \\
\text { years }\end{array}$ & $\begin{array}{l}18-19 \\
\text { years }\end{array}$ & $\begin{array}{l}15-19 \\
\text { years }\end{array}$ & $\begin{array}{l}20-24 \\
\text { years }\end{array}$ \\
\hline \multicolumn{9}{|l|}{ Mainland } \\
\hline Arusha & 0 & 0 & 0 & 1.3 & * & * & * & * \\
\hline Dar es Salaam & 2.1 & 2.7 & 2.2 & 3.3 & * & * & 9.4 & * \\
\hline Dodoma & 2 & * & 1.5 & 4 & * & * & * & * \\
\hline Iringa & 0 & 0 & 0 & 3.5 & * & * & 9 & * \\
\hline Kagera & 0 & 1.7 & 0.7 & 5.3 & * & * & * & * \\
\hline Kigoma & 0 & 0 & 0 & 0.6 & * & * & * & * \\
\hline Kilimanjaro & 0 & * & 0 & 4.2 & * & * & 0 & * \\
\hline Lindi & * & * & 7.2 & 17.1 & * & * & * & * \\
\hline Manyara & 0 & 1.7 & 0.6 & 1.4 & * & * & * & * \\
\hline Mara & 7.2 & 7.9 & 7.4 & 1.7 & * & * & 11.4 & * \\
\hline Mbeya & 1.4 & * & 1 & 7.6 & * & * & 0 & * \\
\hline Morogoro & 0 & 3 & 1.5 & 5.3 & * & * & 10 & * \\
\hline Mtwara & 2.6 & * & 8.4 & 22 & * & * & * & * \\
\hline Mwanza & 0 & 7.6 & 2.7 & 5.8 & 6.4 & * & 10.6 & 39.9 \\
\hline Pwani & 3.2 & * & 1.9 & 5.3 & * & * & * & * \\
\hline Rukwa & 0 & * & 0 & 4.1 & * & * & * & * \\
\hline Ruvuma & 0 & * & 0 & 2.7 & * & * & * & * \\
\hline Shinyanga & 0 & 6.1 & 2.6 & 5.2 & * & * & 6.9 & * \\
\hline Singida & 0 & * & 1 & 2.7 & * & * & 2.7 & * \\
\hline Tabora & 0 & 2.4 & 0.9 & 5.1 & * & * & 13.4 & * \\
\hline Tanga & 0 & * & 3.7 & 3.2 & * & * & * & * \\
\hline \multicolumn{9}{|l|}{ Zanzibar } \\
\hline $\begin{array}{l}\text { Kaskazini } \\
\text { Unguja }\end{array}$ & 0 & 0 & 0 & 0 & 3.4 & * & 2.2 & 0 \\
\hline Kusini Unguja & 0 & 2.7 & 1.1 & 4.8 & * & * & 7.2 & 9.6 \\
\hline Mjini Magharibi & 0 & 0 & 0 & 0.9 & * & * & 0 & * \\
\hline $\begin{array}{l}\text { Kaskazini } \\
\text { Pemba }\end{array}$ & 0 & 0 & 0 & 0 & * & * & 0 & * \\
\hline Kusini Pemba & 0 & 0 & 0 & 0 & * & * & 0 & 0 \\
\hline Mainland & 0.9 & 4 & 2 & 4.9 & 4.2 & 11.7 & 7 & 21.4 \\
\hline Zanzibar & 0 & 0.3 & 0.1 & 0.8 & 0.7 & 2 & 1.2 & 1.7 \\
\hline Urban & 1.1 & 2.2 & 1.5 & 3.6 & 2.5 & 5.2 & 3.7 & 11.3 \\
\hline Rural & 0.8 & 4.5 & 2.1 & 5.3 & 4.6 & 13.8 & 7.9 & 24.8 \\
\hline National & 0.9 & 3.9 & 1.9 & 4.7 & 4.1 & 11.3 & 6.8 & 20.8 \\
\hline
\end{tabular}




\begin{tabular}{|c|c|c|c|c|c|c|c|c|}
\hline \multicolumn{9}{|c|}{$\begin{array}{cc}\text { Annex Table 40B: } & \text { Percent of Females and Males Ages 15-24 Who Had 2+ Partners in Past } 12 \text { Months } \\
\text { (THMIS 2011-2012) }\end{array}$} \\
\hline \multirow[b]{2}{*}{ Region } & \multicolumn{4}{|c|}{ Females } & \multicolumn{4}{|c|}{ Males } \\
\hline & $\begin{array}{l}15-17 \\
\text { years }\end{array}$ & $\begin{array}{l}18-19 \\
\text { years }\end{array}$ & $\begin{array}{l}15-19 \\
\text { years }\end{array}$ & $\begin{array}{l}20-24 \\
\text { years }\end{array}$ & $\begin{array}{l}15-17 \\
\text { years }\end{array}$ & $\begin{array}{l}18-19 \\
\text { years }\end{array}$ & $\begin{array}{l}15-19 \\
\text { years }\end{array}$ & $\begin{array}{l}20-24 \\
\text { years }\end{array}$ \\
\hline \multicolumn{9}{|l|}{ Mainland } \\
\hline Arusha & 1.3 & 0 & 0.8 & 1.7 & 4.9 & * & 3.6 & 12.9 \\
\hline Dar es Salaam & 2.5 & 5.8 & 3.9 & 4.7 & 2 & 6.9 & 4.4 & 27.4 \\
\hline Dodoma & * & * & 0 & 4.8 & 10.5 & * & 13.1 & 10.3 \\
\hline Geita & 7 & 3.7 & 6 & 2.8 & 7.3 & 17.6 & 11 & 39.7 \\
\hline Iringa & 0 & 0 & 0 & 0 & 0.1 & 0 & 0.1 & 4 \\
\hline Kagera & 0 & 0 & 0 & 0 & 0 & * & 0 & 9.2 \\
\hline Katavi & 0 & 0 & 0 & 0 & 0 & * & 4.5 & 14.5 \\
\hline Kigoma & 1.7 & 2.5 & 2 & 2.1 & 6.9 & 1.9 & 4.6 & 5.4 \\
\hline Kilimanjaro & 0 & 3 & 1.2 & 0 & 0 & 3.1 & 1.4 & 3.3 \\
\hline Lindi & 6.5 & * & 5.9 & 13 & 12.2 & * & 8.4 & 31.2 \\
\hline Manyara & 0 & 0 & 0 & 1.6 & 7.8 & 11 & 9.4 & 17.4 \\
\hline Mara & 0 & 0 & 0 & 10.6 & 5.8 & 29.6 & 13.2 & 34.3 \\
\hline Mbeya & 0 & 2 & 0.8 & 0 & 0 & 13.3 & 5.2 & 28.9 \\
\hline Morogoro & 0 & 12 & 6.6 & 5.6 & 0 & 22.4 & 11.4 & 22.1 \\
\hline Mtwara & 7.1 & * & 7.2 & 21.3 & 9.9 & * & 8 & 14.1 \\
\hline Mwanza & 5.4 & 2.8 & 4.5 & 12.2 & 3.8 & 5.1 & 4.3 & 19.7 \\
\hline Njombe & 0 & * & 0 & 3.4 & 2.2 & * & 6 & 28.6 \\
\hline Pwani & 0 & * & 0 & 4.6 & 9.6 & 11.7 & 10.5 & 26 \\
\hline Rukwa & 3.2 & * & 5.2 & 3.8 & 0 & * & 8.7 & 3.7 \\
\hline Ruvuma & 2.7 & 1 & 2 & 5.7 & 7.4 & * & 19.4 & 47.5 \\
\hline Shinyanga & 4.7 & 13.7 & 8.3 & 5.8 & 6.6 & * & 4.3 & 31.8 \\
\hline Simiyu & 8.3 & 8 & 8.2 & 9.1 & 4.2 & 10.5 & 6.5 & 29.6 \\
\hline Singida & 6.2 & 0 & 3.7 & 0.9 & 7.4 & 19.1 & 12.2 & 21.7 \\
\hline Tabora & 4.2 & 2.1 & 3.4 & 4.7 & 3.8 & 6.7 & 4.9 & 16.2 \\
\hline Tanga & 0 & 0 & 0 & 0 & 6.4 & * & 9.6 & 36.5 \\
\hline \multicolumn{9}{|l|}{ Zanzibar } \\
\hline $\begin{array}{l}\text { Kaskazini } \\
\text { Unguja }\end{array}$ & 1.7 & 0 & 1.1 & 0 & 2.2 & * & 1.3 & 0 \\
\hline Kusini Unguja & 0 & * & 0 & 2.8 & 0 & * & 1.9 & 1.7 \\
\hline Mjini Magharibi & 0 & 0 & 0 & 0 & 0 & * & 3.5 & 6.2 \\
\hline $\begin{array}{l}\text { Kaskazini } \\
\text { Pemba }\end{array}$ & 0 & 0 & 0 & 0 & 0 & 0 & 0 & 0 \\
\hline Kusini Pemba & 0 & 0 & 0 & 1.4 & 1.1 & * & 0.8 & 3.6 \\
\hline Mainland & 2.8 & 3.5 & 3.1 & 4.8 & 4.5 & 11.4 & 7.2 & 23.8 \\
\hline Zanzibar & 0.2 & 0 & 0.1 & 0.3 & 0.4 & 5.2 & 2.3 & 4.4 \\
\hline Urban & 2.1 & 4.6 & 3.1 & 5.9 & 2.4 & 3.9 & 3.1 & 24.8 \\
\hline Rural & 2.9 & 3 & 2.9 & 4.2 & 4.9 & 13.7 & 8.3 & 22.3 \\
\hline National & 2.7 & 3.4 & 3 & 4.6 & 4.3 & 11.2 & 7.1 & 23.1 \\
\hline
\end{tabular}




\begin{tabular}{|c|c|c|c|c|c|c|c|c|}
\hline \multicolumn{9}{|c|}{$\begin{array}{c}\text { Annex Table 41A: Among Females and Males Who Had More than One Partner in Past } 12 \text { Months, } \\
\text { Percent Reporting a Condom Was Used at Last Sex (DHS, 2010) }\end{array}$} \\
\hline \multirow[b]{2}{*}{ Region } & \multicolumn{4}{|c|}{ Females } & \multicolumn{4}{|c|}{ Males } \\
\hline & $\begin{array}{l}15-17 \\
\text { years }\end{array}$ & $\begin{array}{l}\text { 18-19 } \\
\text { years }\end{array}$ & $\begin{array}{l}15-19 \\
\text { years }\end{array}$ & $\begin{array}{l}20-24 \\
\text { years }\end{array}$ & $\begin{array}{l}15-17 \\
\text { years }\end{array}$ & $\begin{array}{l}18-19 \\
\text { years }\end{array}$ & $\begin{array}{l}15-19 \\
\text { years }\end{array}$ & $\begin{array}{l}20-24 \\
\text { years }\end{array}$ \\
\hline Mainland & * & * & 35.3 & 29.9 & * & * & 34.2 & 37.9 \\
\hline Zanzibar & * & * & * & * & * & * & * & * \\
\hline Urban & * & * & * & * & * & * & * & * \\
\hline Rural & * & * & 38.4 & 28.5 & * & * & 35.1 & 36.3 \\
\hline National & * & * & 35.3 & 29.9 & * & * & 34.2 & 38.1 \\
\hline
\end{tabular}

\begin{tabular}{|c|c|c|c|c|c|c|c|c|}
\hline \multicolumn{9}{|c|}{$\begin{array}{c}\text { Annex Table 41B: Among Females and Males Who Had More than One Partner in Past } 12 \text { Months, } \\
\text { Percent Reporting a Condom Was Used at Last Sex (THMIS 2011-2012) }\end{array}$} \\
\hline \multirow[b]{2}{*}{ Region } & \multicolumn{4}{|c|}{ Females } & \multicolumn{4}{|c|}{ Males } \\
\hline & $\begin{array}{l}15-17 \\
\text { years }\end{array}$ & $\begin{array}{l}18-19 \\
\text { years }\end{array}$ & $\begin{array}{l}15-19 \\
\text { years }\end{array}$ & $\begin{array}{l}20-24 \\
\text { years }\end{array}$ & $\begin{array}{l}15-17 \\
\text { years }\end{array}$ & $\begin{array}{l}18-19 \\
\text { years }\end{array}$ & $\begin{array}{l}15-19 \\
\text { years }\end{array}$ & $\begin{array}{l}20-24 \\
\text { years }\end{array}$ \\
\hline Mainland & 46.2 & 27.9 & 37.8 & 30.9 & 44.7 & 44.6 & 44.6 & 38.7 \\
\hline Zanzibar & * & * & * & * & * & * & * & 60.8 \\
\hline Urban & * & * & * & * & * & * & * & 49.1 \\
\hline Rural & * & * & * & * & * & * & * & 33.9 \\
\hline National & 46.1 & 27.9 & 37.7 & 30.8 & 44.5 & 45.5 & 45.2 & 38.8 \\
\hline
\end{tabular}


Annex Table 43A: Percent of Females Ages 15-24 Who Believe if Husband Has a Sexually Transmitted Disease, His Wife is Justified in Asking that He Use a Condom (DHS, 2010)

\begin{tabular}{|c|c|c|c|c|}
\hline Region & $15-17$ years & 18-19 years & $15-19$ years & 20-24 years \\
\hline \multicolumn{5}{|l|}{ Mainland } \\
\hline Arusha & 55 & 69.7 & 60.4 & 61.3 \\
\hline $\begin{array}{c}\text { Dar Es } \\
\text { Salaam }\end{array}$ & 83.3 & 96.3 & 87.5 & 90.7 \\
\hline Dodoma & 78.6 & * & 82.6 & 85.5 \\
\hline Iringa & 71.6 & 78.5 & 74.4 & 86.9 \\
\hline Kagera & 85.2 & 81.4 & 83.8 & 89.6 \\
\hline Kigoma & 82.6 & 92.3 & 85.3 & 91.7 \\
\hline Kilimanjaro & 76.5 & * & 83.8 & 78.4 \\
\hline Lindi & * & * & 87.9 & 92.5 \\
\hline Manyara & 27.2 & 65.7 & 41.7 & 62.9 \\
\hline Mara & 92 & 71.5 & 84.8 & 85.3 \\
\hline Mbeya & 67.4 & * & 69.1 & 79.5 \\
\hline Morogoro & 74.5 & 82.4 & 78.4 & 88.4 \\
\hline Mtwara & 70.7 & * & 76.1 & 84.5 \\
\hline Mwanza & 59.9 & 70.3 & 63.6 & 73.9 \\
\hline Pwani & 86.4 & * & 85.9 & 83 \\
\hline Rukwa & 62.7 & * & 64.8 & 73.7 \\
\hline Ruvuma & 75.4 & * & 80.3 & 89.9 \\
\hline Shinyanga & 66.7 & 90.1 & 76.7 & 85.5 \\
\hline Singida & 81.1 & * & 79.5 & 77.8 \\
\hline Tabora & 73.9 & 89.3 & 79.9 & 78 \\
\hline Tanga & 72 & * & 74 & 82 \\
\hline \multicolumn{5}{|l|}{ Zanzibar } \\
\hline Unguja N. & 34.7 & 66 & 46.7 & 70 \\
\hline Unguja S. & 69.8 & 64.7 & 67.8 & 72.6 \\
\hline Town West & 59.5 & 64.7 & 61.5 & 77.8 \\
\hline Pemba North & 43.4 & 53 & 46.7 & 63.9 \\
\hline Pemba South & 49.2 & 68.4 & 55.8 & 75 \\
\hline Mainland & 72.9 & 82.8 & 76.4 & 82.9 \\
\hline Zanzibar & 50.9 & 63.4 & 55.6 & 73.3 \\
\hline Urban & 79.2 & 85 & 81.3 & 88.9 \\
\hline Rural & 69 & 80.9 & 73.3 & 79.5 \\
\hline National & 72.1 & 82.1 & 75.7 & 82.6 \\
\hline
\end{tabular}


Annex Table 43B: Percent of Females Ages 15-24 Who Believe if Husband Has a Sexually Transmitted Disease, His Wife is Justified in Asking that He Use a Condom (THMIS 2011-2012)

\begin{tabular}{|c|c|c|c|c|}
\hline Region & $15-17$ years & 18-19 years & $15-19$ years & 20-24 years \\
\hline \multicolumn{5}{|l|}{ Mainland } \\
\hline Arusha & 60.9 & 74.1 & 65.8 & 60.9 \\
\hline Dar es Salaam & 74.2 & 90.6 & 81.4 & 94.2 \\
\hline Dodoma & * & * & 71.9 & 74.7 \\
\hline Geita & 61.2 & 74.6 & 65.4 & 76.2 \\
\hline Iringa & 95.1 & 99.6 & 97.7 & 93 \\
\hline Kagera & 76.8 & 79.9 & 78 & 90 \\
\hline Katavi & 49.1 & 76.3 & 60 & 59.4 \\
\hline Kigoma & 66.4 & 71.9 & 68.7 & 87.2 \\
\hline Kilimanjaro & 46.5 & 78.9 & 59.5 & 89.5 \\
\hline Lindi & 78.5 & * & 82.3 & 87.3 \\
\hline Manyara & 41.3 & 57.3 & 46.2 & 62.9 \\
\hline Mara & 65 & 85.6 & 73.6 & 87.8 \\
\hline Mbeya & 48.3 & 76.7 & 59.7 & 73 \\
\hline Morogoro & 66.9 & 61.8 & 64.1 & 92 \\
\hline Mtwara & 63.3 & * & 70.8 & 96.9 \\
\hline Mwanza & 64.4 & 79 & 69.8 & 90.7 \\
\hline Njombe & 75.7 & * & 84.4 & 85.5 \\
\hline Pwani & 89.2 & * & 92.8 & 94.1 \\
\hline Rukwa & 53.6 & * & 62.9 & 80.6 \\
\hline Ruvuma & 83.2 & 82.7 & 83 & 85.5 \\
\hline Shinyanga & 79 & 71 & 75.8 & 83.9 \\
\hline Simiyu & 56.8 & 74.7 & 64.1 & 80.3 \\
\hline Singida & 44.9 & 74.6 & 56.9 & 72.2 \\
\hline Tabora & 72.3 & 89.4 & 78.6 & 83 \\
\hline Tanga & 64.4 & 71.8 & 67.7 & 62.3 \\
\hline \multicolumn{5}{|l|}{ Zanzibar } \\
\hline $\begin{array}{c}\text { Kaskazini } \\
\text { Unguja }\end{array}$ & 33.9 & 42.6 & 36.9 & 62.2 \\
\hline Kusini Unguja & 61.1 & * & 63.1 & 87.3 \\
\hline Mjini Magharibi & 38.7 & 59.4 & 47.7 & 75.1 \\
\hline $\begin{array}{c}\text { Kaskazini } \\
\text { Pemba }\end{array}$ & 33.7 & 59.1 & 43.1 & 56.5 \\
\hline Kusini Pemba & 50.3 & 47.6 & 49.3 & 75.9 \\
\hline Mainland & 64.8 & 79.6 & 70.8 & 82.5 \\
\hline Zanzibar & 40.1 & 57.1 & 47.1 & 72.3 \\
\hline Urban & 74.5 & 90.1 & 80.4 & 89.4 \\
\hline Rural & 59.7 & 74.9 & 66 & 79.3 \\
\hline National & 63.8 & 78.7 & 69.8 & 82.1 \\
\hline
\end{tabular}




\begin{tabular}{|c|c|c|}
\hline \multicolumn{3}{|c|}{$\begin{array}{l}\text { Annex Table 45: Percent of Females Ages } 15-24^{a} \text { who are Currently } \\
\text { Using Contraception (Any Modern Method } \text { ), by Marital Status (DHS, } \\
\text { 2010) }\end{array}$} \\
\hline Region & Currently-married & $\begin{array}{l}\text { Never married (and } \\
\text { ever had sex) }\end{array}$ \\
\hline \multicolumn{3}{|l|}{ Mainland } \\
\hline Arusha & 24.6 & 13.5 \\
\hline Dar es Salaam & 36.2 & 33.6 \\
\hline Dodoma & 31.3 & * \\
\hline Iringa & 41 & 33.2 \\
\hline Kagera & 14 & 27.6 \\
\hline Kigoma & 13.7 & * \\
\hline Kilimanjaro & 42.6 & * \\
\hline Lindi & 38.2 & 37.4 \\
\hline Manyara & 18.1 & 17.1 \\
\hline Mara & 7.9 & 30.6 \\
\hline Mbeya & 36.9 & * \\
\hline Morogoro & 35.2 & 20.1 \\
\hline Mtwara & 25.8 & 32 \\
\hline Mwanza & 5.2 & 20.7 \\
\hline Pwani & 43.6 & * \\
\hline Rukwa & 16.3 & * \\
\hline Ruvuma & 39.2 & 42.6 \\
\hline Shinyanga & 5.2 & 19.6 \\
\hline Singida & 25.8 & * \\
\hline Tabora & 13 & 27.6 \\
\hline Tanga & 16.9 & 51.4 \\
\hline \multicolumn{3}{|l|}{ Zanzibar } \\
\hline $\begin{array}{l}\text { Kaskazini } \\
\text { Unguja }\end{array}$ & 3 & * \\
\hline Kusini Unguja & 42.1 & * \\
\hline $\begin{array}{c}\text { Mjini } \\
\text { Magharibi }\end{array}$ & 16.5 & * \\
\hline $\begin{array}{l}\text { Kaskazini } \\
\text { Pemba }\end{array}$ & 9.6 & * \\
\hline Kusini Pemba & 9 & * \\
\hline Mainland & 21.1 & 29.3 \\
\hline Zanzibar & 13.7 & 0 \\
\hline Urban & 32.1 & 29 \\
\hline Rural & 17.8 & 29.2 \\
\hline National & 20.9 & 29.1 \\
\hline
\end{tabular}




\begin{tabular}{|c|c|c|c|c|c|c|c|c|c|c|c|c|c|c|c|c|}
\hline \multirow[b]{2}{*}{ Region } & \multicolumn{4}{|c|}{ Health professional } & \multicolumn{4}{|c|}{ Traditional birth attendant } & \multicolumn{4}{|c|}{$\begin{array}{l}\text { Other (relative/ friends or village health } \\
\text { worker) }\end{array}$} & \multicolumn{4}{|c|}{ No assistance } \\
\hline & $\begin{array}{l}15-17 \\
\text { years }\end{array}$ & $\begin{array}{l}\text { 18-19 } \\
\text { years }\end{array}$ & $\begin{array}{l}15-19 \\
\text { years }\end{array}$ & $\begin{array}{l}20-24 \\
\text { years }\end{array}$ & $\begin{array}{l}15-17 \\
\text { years }\end{array}$ & $\begin{array}{l}18-19 \\
\text { years }\end{array}$ & $\begin{array}{l}15-19 \\
\text { years }\end{array}$ & $\begin{array}{l}20-24 \\
\text { years }\end{array}$ & $\begin{array}{l}15-17 \\
\text { years }\end{array}$ & $\begin{array}{l}18-19 \\
\text { years }\end{array}$ & $\begin{array}{l}15-19 \\
\text { years }\end{array}$ & $\begin{array}{l}20-24 \\
\text { years }\end{array}$ & $\begin{array}{l}15-17 \\
\text { years }\end{array}$ & $\begin{array}{l}18-19 \\
\text { years }\end{array}$ & $\begin{array}{l}15-19 \\
\text { years }\end{array}$ & $\begin{array}{l}20-24 \\
\text { years }\end{array}$ \\
\hline Mainland & 57.8 & 62.1 & 60.8 & 57.9 & 8 & 11.8 & 10.6 & 11.6 & 32.2 & 25.2 & 27.4 & 28.4 & 2 & 0.8 & 1.2 & 2.1 \\
\hline Zanzibar & * & * & 57.4 & 55.8 & * & * & 33.6 & 35.9 & * & * & 9 & 8.3 & * & * & 0 & 0 \\
\hline Urban & * & 86.5 & 84.8 & 86.2 & * & 8.8 & 5.4 & 6.2 & * & 4.7 & 9.7 & 6.3 & * & 0 & 0 & 1.2 \\
\hline Rural & 49.1 & 56.4 & 54.3 & 48.3 & 11.2 & 12.8 & 12.3 & 14 & 37 & 29.9 & 31.9 & 35.4 & 2.7 & 1 & 1.5 & 2.4 \\
\hline National & 57.8 & 62.1 & 60.8 & 57.9 & 8.2 & 12 & 10.9 & 12 & 32 & 25.1 & 27.2 & 28 & 2 & 0.8 & 1.2 & 2.1 \\
\hline
\end{tabular}

a- for most recent birth in first five years

proceeding the survey

b- health professional $=$ includes doctor/AMO, clinical officer, assistant clinical

officer, nurse/midwife, $\mathrm{MCH}$ aide

c- traditional birth attendant

$=$ TBA

$\mathrm{d}$ - other= village health care worker, relatives/friends of the

woman, and other assistance 